\author{
UNIVERSIDADE DE SÃO PAULO \\ ESCOLA DE ARTES, CIÊNCIAS E HUMANIDADES \\ PROGRAMA DE PÓS-GRADUAÇÃO EM GESTÃo DE POLÍTICAS PÚBLICAS
}

ISABELA DE OLIVEIRA MENON

Gestão Social como campo do saber no Brasil: uma análise de sua produção científica pela modelagem de redes sociais (2005-2015) 


\title{
Gestão Social como campo do saber no Brasil: uma análise de sua produção científica pela modelagem de redes sociais (2005-2015)
}

\author{
Versão corrigida.
}

Dissertação apresentada à Escola de Artes, Ciências e Humanidades da Universidade de São Paulo para obtenção do título de Mestre em Ciências pelo Programa de Pós-graduação em Gestão de Políticas Públicas.

\begin{abstract}
Versão corrigida contendo as alterações solicitadas pela comissão julgadora em 13 de maio de 2016. A versão original encontra-se em acervo reservado na Biblioteca da EACH/USP e na Biblioteca Digital de Teses e Dissertações da USP (BDTD), de acordo com a Resolução CoPGr 6018, de 13 de outubro de 2011.
\end{abstract}

Área de Concentração:

Análise de Políticas Públicas

Linha de Pesquisa:

Economia e Gestão do Setor Público

Orientador:

Prof. Dr. Fernando de Souza Coelho 
Autorizo a reprodução e divulgação total ou parcial deste trabalho, por qualquer meio convencional ou eletrônico, para fins de estudo e pesquisa, desde que citada a fonte.

Menon, Isabela de Oliveira

Gestão social como campo do saber no Brasil : uma análise de sua produção científica pela modelagem de redes sociais (2005-2015) / Isabela de Oliveira Menon ; orientador, Fernando de Souza Coelho. São Paulo, 2016

222 f. : il.

Dissertação (Mestrado em Ciências) - Programa de PósGraduação em Gestão de Políticas Públicas, Escola de Artes, Ciências e Humanidades, Universidade de São Paulo, São Paulo. Versão corrigida

1. Gestão social. 2. Gestão social - Análise - Brasil. 3. Política social - Brasil. 4. Produção científica - Análise - Brasil. 5. Redes sociais. I. Coelho, Fernando de Souza, orient. II. Título

CDD 22.ed. -361.25 
Nome: MENON, Isabela de Oliveira

Título: Gestão Social como campo do saber no Brasil: uma análise de sua produção científica pela modelagem de redes sociais (2005-2015)

Dissertação apresentada à Escola de Artes, Ciências e Humanidades da Universidade de São Paulo para obtenção do título de Mestre em Ciências pelo Programa de Pós-graduação em Gestão de Políticas Públicas.

Aprovada em 13 de maio de 2016.

\section{BANCA EXAMINADORA (TITULARES)}

Prof. Dr. Fernando de Souza Coelho

(orientador)

Universidade de São Paulo

Assinatura:

Prof. ${ }^{\text {a Dr. }}{ }^{\text {a }}$ Patricia Maria Emerenciano de Mendonça

Universidade de São Paulo

Assinatura:

Prof. Dr. Luciano Antonio Prates Junqueira Pontifícia Universidade Católica de São Assinatura: Paulo

Prof. Dr. Airton Cardoso Cançado Universidade Federal do Tocantins 
BANCA EXAMINADORA (SUPLENTES)

Prof. Dr. José Carlos Vaz

Universidade de São Paulo

Assinatura:

Prof. ${ }^{a}$ Dr. ${ }^{a}$ Sylmara Lopes Francelino

Gonçalves Dias

Universidade de São Paulo

Assinatura:

Prof. Dr. Edgilson Tavares de Araújo

Universidade Federal do Recôncavo da Bahia Assinatura: 
Aos meus avós,

Benedito e Isabel,

Vasco e Rumilda 


\section{AGRADECIMENTOS}

Ao Professor Fernando de Souza Coelho, que participou ativamente da minha caminhada acadêmica, sempre me orientando com presteza e paciência.

Às Professoras Patrícia Maria Emerenciano de Mendonça e Sylmara Lopes Francelino Gonçalves-Dias, pelas entrevistas concedidas, as quais contribuíram para o delineamento da minha pesquisa.

Aos Professores Luciano Antonio Prates Junqueira, Patrícia Maria Emerenciano de Mendonça e Airton Cardoso Cançado, pelos comentários e sugestões feitos durante o exame de qualificação e a banca de defesa, que foram essenciais para o refinamento do estudo.

Aos Professores Jeová Torres Silva Júnior e Ariádne Scalfoni Rigo, pela prontidão em ajudar-me a recuperar os artigos que foram base para a realização deste trabalho.

Aos pesquisadores da Rede de Pesquisadores de Gestão Social (RGS) - RGS, pelo acolhimento na Reunião da RGS realizada em maio de 2015 e pelas valiosas sugestões que encorparam minha pesquisa.

Aos colegas, Paula Trottmann e Victor Corrêa Silva, - que me antecederam em trabalhos dessa natureza analisando as redes de pesquisadores em Políticas Públicas e Administração Pública, respectivamente -, pelo apoio e auxílio desde a concepção do projeto de pesquisa até a finalização da dissertação.

Aos docentes e funcionários da Universidade de São Paulo, em especial aqueles pertencentes ao Programa de Pós-graduação em Gestão de Políticas Públicas, pelo convívio e amizade durante esses dois anos.

Aos meus pais (Helio e Ana Lúcia), meu irmão (Renato), minha madrinha (Maria Célia) e meu tio (José Antonio Leite de Oliveira), que me apoiaram durante toda essa caminhada, confortando-me nos momentos difíceis e vibrando comigo nas vitórias.

Ao meu companheiro, Marcel Felices, por ser minha inspiração e pelo incentivo e suporte constantes.

Aos meus amigos e companheiros de mestrado, que compartilharam comigo essa experiência e tornaram esse processo mais leve e alegre.

A Deus, que me concedeu essa oportunidade e abençoou minha trajetória. 


\section{RESUMO}

MENON, Isabela de Oliveira. Gestão Social como campo do saber no Brasil: uma análise de sua produção científica pela modelagem de redes sociais (2005-2015). 2016. 222 f. Dissertação (Mestrado em Gestão de Políticas Públicas) - Escola de Artes, Ciências e Humanidades, Universidade de São Paulo, São Paulo, 2016. Versão Corrigida.

Esta dissertação debruça-se sobre o mapeamento e a construção da rede de produção científica do campo de Gestão Social no Brasil, visando a identificação das principais características predominantes no campo associadas à formação acadêmica e vinculação institucional, além da concentração temática e dinâmica de relacionamento dos pesquisadores. A partir dessa análise, foi possível verificar a evolução do campo por meio da rede de produção científica na última década, verificando seu desenvolvimento e suas peculiaridades, além de contribuir com o debate em torno da construção da identidade da área de pesquisa em Gestão Social. Os principais indicadores gerados são: artigos publicados; artigos por autor; autores por artigo; autores mais prolíficos; grau de aninhamento de atores; tamanho e componentes da rede social, etc. A presente pesquisa busca complementar os estudos bibliométricos realizados no campo da Gestão Social anteriormente e expandir o universo analisado para além do Encontro Nacional de Pesquisadores em Gestão Social (ENAPEGS), proporcionando uma visão global do que é a área de Gestão Social no Brasil atualmente. Para tanto, foram coletados dados dos principais eventos (ENAPEGS, EMAPEGS, EnANPAD, EnAPG, Colóquio Internacional sobre Poder Local) e periódicos (RAP, O\&S, Cadernos EBAPE.BR, APGS, RIGS, NAU Social, Cadernos de Gestão Social (CGS), Cadernos de Gestão Pública e Cidadania) no período de 2005 a 2015.

Palavras-chave: Gestão Social. Produção científica. Redes sociais. 


\begin{abstract}
MENON, Isabela de Oliveira. Social management as a field of knowledge in Brazil: an analysis of its scientific production by modeling social networks (2005-2015). 2016. 222 f. Dissertação (Mestrado em Gestão de Políticas Públicas) - Escola de Artes, Ciências e Humanidades, Universidade de São Paulo, São Paulo, 2016. Versão Corrigida.
\end{abstract}

This thesis focuses on mapping and construction of scientific production network of social management field in Brazil, aiming to identify the main predominant characteristics of the field associated with the academic and institutional affiliation, as well as thematic concentration and relationship dynamics between researchers. Based on this analysis, it was possible to verify the evolution of the field through scientific production network over the past decade, checking its development and its peculiarities, besides contributing to the debate on the construction of the identity of the research area in social management. The main indicators derived are: published articles; articles per author; authors per article; most prolific authors; degree of nesting actors; size and components of the social network, etc. The research will complement previous studies and expand the universe analyzed in addition to the National Meeting of Researchers in Social Management (ENAPEGS), providing a global view of what is the area of social management in Brazil today. To achieve this goal were collected data of the main events (ENAPEGS, EMAPEGS, EnANPAD, EnAPG, Colóquio Internacional sobre Poder Local) and journals (RAP, O\&S, Cadernos EBAPE.BR, APGS, RIGS, NAU Social, Cadernos de Gestão Social (CGS), Cadernos de Gestão Pública e Cidadania) in the period 2005-2015.

Keywords: Social management. Scientific production. Social network. 


\section{LISTA DE ILUSTRAÇÕES}

\section{GRÁFICOS}

Gráfico 1: Evolução do volume de artigos na "Rede de Pesquisadores de Gestão Social (RPGS)",

Gráfico 2: Evolução do número de pesquisadores na "Rede de Pesquisadores de Gestão Social (RPGS)",

Gráfico 3: Colaboração e Produtividade da "Rede de Pesquisadores de Gestão Social (RPGS)".

Gráfico 4: Número de autores por artigo

\section{QUADROS}

Quadro 1: Principais autores e perspectivas de Gestão Social 45

Quadro 2: cursos de graduação em Gestão Social....................................................................56

Quadro 3: cursos de pós-graduação lato-sensu em Gestão Social ..........................................56

Quadro 4: Grupos de pesquisa com o termo "Gestão Social" em sua denominação cadastrados na Plataforma Lattes em 2016

Quadro 5: grupos de pesquisa com linha de pesquisa contendo o termo "Gestão Social" cadastrados na Plataforma Lattes em 2016.

Quadro 6: Temas e eixos temáticos do Encontro Nacional de Pesquisadores em Gestão Social (ENAPEGS) de 2007 a 2014 63

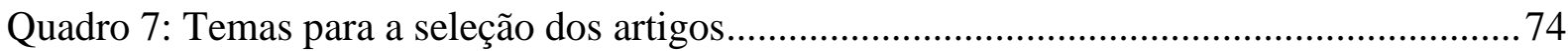

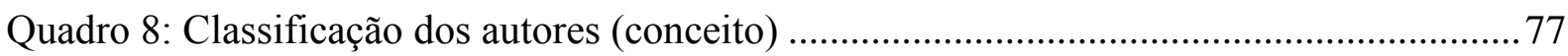

Quadro 9: Indicadores de produtividade e colaboração ........................................................ 78

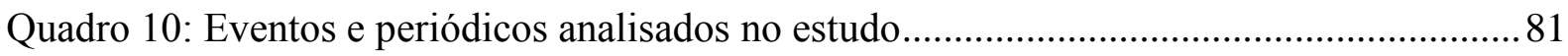

Quadro 11: Atributos dos autores mais prolíficos da "Rede de Pesquisadores de Gestão Social (RPGS)",

Quadro 12: Formação acadêmica e atuação profissional dos autores com maior centralidade de grau (degree) da "Rede de Pesquisadores de Gestão Social (RPGS)"

Quadro 13: Formação acadêmica e atuação profissional dos autores com maior centralidade de intermediação (betweenness) da "Rede de Pesquisadores de Gestão Social (RPGS)".

Quadro 14: Formação acadêmica e atuação profissional dos autores com maior centralidade de autovetor (eigenvector) da "Rede de Pesquisadores de Gestão Social (RPGS)" 99 
Quadro 15: Atributos dos principais autores da Rede de Pesquisadores do ENAPEGS........ 104

Quadro 16: Atributos dos principais autores da Rede de Pesquisadores do EnANPAD .......110

Quadro 17: Atributos dos principais autores da Rede de Pesquisadores do Colóquio

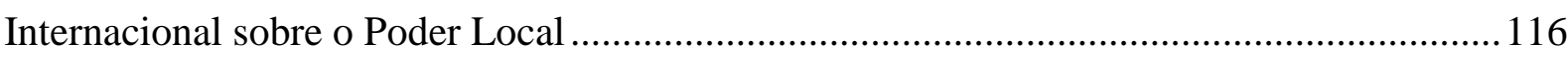

Quadro 18: Atributos dos principais autores da Rede de Pesquisadores do EnAPG ............. 121

Quadro 19: Atributos dos principais autores da Rede de Pesquisadores do EMAPEGS ....... 126

Quadro 20: Atributos dos principais autores da Rede de Pesquisadores da Revista de

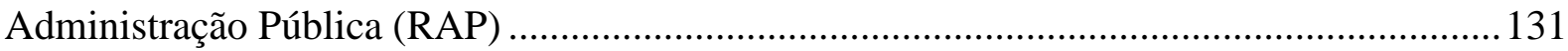

Quadro 21: Atributos dos principais autores da Rede de Pesquisadores dos Cadernos EBAPE.BR

Quadro 22: Atributos dos principais autores da Rede de Pesquisadores da da Revista Organizações \& Sociedade (O\&S)

Quadro 23: Atributos dos principais autores da Rede de Pesquisadores dos Cadernos de Gestão Pública e Cidadania

Quadro 24: Atributos dos principais autores da Rede de Pesquisadores da Administração Pública e Gestão Social (APGS)

Quadro 25: Atributos dos principais autores da Rede de Pesquisadores da NAU Social ...... 156

Quadro 26: Atributos dos principais autores da Rede de Pesquisadores dos Cadernos de Gestão Social (CGS)

Quadro 27: Atributos dos principais autores da Rede de Pesquisadores da Revista Interdisciplinar de Gestão Social (RIGS) 165

Quadro 28: Comparação das medidas calculadas. 168

\section{TABELAS}

Tabela 1: Volume de artigos na "Rede de Pesquisadores de Gestão Social (RPGS)" por ano 83 Tabela 2: Índices da "Rede de Pesquisadores de Gestão Social (RPGS)" 85

Tabela 3: Classificação dos pesquisadores da "Rede de Pesquisadores de Gestão Social (RPGS)"..... 88

Tabela 4: Comparação entre a classificação dos pesquisadores dos campos de Gestão Social, Políticas Públicas e Administração Pública 89

Tabela 5: Volume e padrão de produção científica por categoria de autor

Tabela 6: Relação entre pesquisadores continuantes e outros pesquisadores (publicações não exclusivas) 
Tabela 7: Relação entre pesquisadores continuantes e outros pesquisadores (publicações exclusivas)

Tabela 8: Os dez autores mais prolíficos da "Rede de Pesquisadores de Gestão Social (RPGS)".....

Tabela 9: Centralidade de grau (degree) da "Rede de Pesquisadores de Gestão Social (RPGS)"

Tabela 10: Centralidade de intermediação (betweeneess) da "Rede de Pesquisadores de Gestão Social (RPGS)",

Tabela 11: Centralidade de autovetor (eigenvector) da "Rede de Pesquisadores de Gestão Social (RPGS)". 98

Tabela 12: Autores mais prolíficos da Rede de Pesquisadores do ENAPEGS 102

Tabela 13: Medidas de centralidade da Rede de Pesquisadores do ENAPEGS ..................... 102

Tabela 14: Categorização dos Pesquisadores da Rede de Pesquisadores do ENAPEGS....... 106

Tabela 15: Autores mais prolíficos da Rede de Pesquisadores do EnANPAD 107

Tabela 16: Medidas de centralidade da Rede de Pesquisadores do EnANPAD 108

Tabela 17: Categorização dos Pesquisadores da Rede de Pesquisadores do EnANPAD 111

Tabela 18: Autores mais prolíficos da Rede de Pesquisadores do Colóquio Internacional sobre o Poder Local

Tabela 19: Medidas de centralidade da Rede de Pesquisadores do Colóquio Internacional sobre o Poder Local 114

Tabela 20: Categorização dos Pesquisadores da Rede de Pesquisadores do Colóquio Internacional sobre o Poder Local

Tabela 21: Autores mais prolíficos da Rede de Pesquisadores do EnAPG

Tabela 22: Medidas de centralidade da Rede de Pesquisadores do EnAPG

Tabela 23: Categorização dos Pesquisadores da Rede de Pesquisadores do EnAPG

Tabela 24: Autores mais prolíficos da Rede de Pesquisadores do EMAPEGS. 124

Tabela 25: Medidas de centralidade da Rede de Pesquisadores do EMAPEGS 124

Tabela 26: Categorização dos Pesquisadores da Rede de Pesquisadores do EMAPEGS 128

Tabela 27: Autores mais prolíficos da Rede de Pesquisadores da Revista de Administração Pública (RAP)

Tabela 28: Medidas de centralidade da Rede de Pesquisadores da Revista de Administração Pública (RAP) 
Tabela 29: Categorização dos Pesquisadores da Rede de Pesquisadores da Revista de Administração Pública (RAP)

Tabela 30: Autores mais prolíficos da Rede de Pesquisadores dos Cadernos EBAPE.BR....134 Tabela 31: Medidas de centralidade da Rede de Pesquisadores dos Cadernos EBAPE.BR .. 135 Tabela 32: Categorização dos Pesquisadores da Rede de Pesquisadores dos Cadernos EBAPE.BR

Tabela 33: Autores mais prolíficos da Rede de Pesquisadores da Revista Organizações \& Sociedade $(\mathrm{O} \& S)$

Tabela 34: Medidas de centralidade da Rede de Pesquisadores da Revista Organizações \& Sociedade $(\mathrm{O} \& \mathrm{~S})$

Tabela 35: Categorização dos Pesquisadores da Rede de Pesquisadores da Revista Organizações \& Sociedade (O\&S) 143

Tabela 36: Autores mais prolíficos da Rede de Pesquisadores dos Cadernos de Gestão Pública e Cidadania 144

Tabela 37: Medidas de centralidade da Rede de Pesquisadores dos Cadernos de Gestão Pública e Cidadania 145

Tabela 38: Categorização dos Pesquisadores da Rede de Pesquisadores dos Cadernos de Gestão Pública e Cidadania

Tabela 39: Autores mais prolíficos da Rede de Pesquisadores da Administração Pública e Gestão Social (APGS)

Tabela 40: Medidas de centralidade da Rede de Pesquisadores da Administração Pública e Gestão Social (APGS)

Tabela 41: Categorização dos Pesquisadores da Rede de Pesquisadores da Administração Pública e Gestão Social (APGS)

Tabela 42: Autores mais prolíficos da Rede de Pesquisadores da NAU Social 153

Tabela 43: Medidas de centralidade da Rede de Pesquisadores da NAU Social 154

Tabela 44: Categorização dos Pesquisadores da Rede de Pesquisadores da NAU Social ..... 157 Tabela 45: Autores mais prolíficos da Rede de Pesquisadores dos Cadernos de Gestão Social (CGS)

Tabela 46: Medidas de centralidade da Rede de Pesquisadores dos Cadernos de Gestão Social (CGS)

Tabela 47: Categorização dos Pesquisadores da Rede de Pesquisadores dos Cadernos de Gestão Social (CGS) 
Tabela 48: Autores mais prolíficos da Rede de Pesquisadores da Revista Interdisciplinar de Gestão Social (RIGS)

Tabela 49: Medidas de centralidade da Rede de Pesquisadores da Revista Interdisciplinar de Gestão Social (RIGS) 164

Tabela 50: Categorização dos Pesquisadores da Rede de Pesquisadores da Revista Interdisciplinar de Gestão Social (RIGS) 166

\section{FIGURAS}

Figura 1: Representação do Campo de Públicas 23

Figura 2: Modelo de estruturação da base de dados 78

Figura 3: "Rede de Pesquisadores de Gestão Social (RPGS)" com os autores mais prolíficos em destaque 92

Figura 4: Representação gráfica da centralidade de grau (degree) da "Rede de Pesquisadores de Gestão Social (RPGS)" 95

Figura 5: Representação gráfica da centralidade de intermediação (betweenness) da "Rede de Pesquisadores de Gestão Social (RPGS)"

Figura 6: Representação gráfica da centralidade de autovetor (eigenvector) da "Rede de Pesquisadores de Gestão Social (RPGS)"

Figura 7: Rede de Pesquisadores do ENAPEGS 101

Figura 8: Representação gráfica da centralidade de grau (degree), centralidade de intermediação (betweenness) e centralidade de autovetor (eigenvector) da Rede de Pesquisadores do ENAPEGS 103

Figura 9: Rede de Pesquisadores do EnANPAD 107

Figura 10: Representação gráfica da centralidade de grau (degree), centralidade de intermediação (betweenness) e centralidade de autovetor (eigenvector) da Rede de Pesquisadores do EnANPAD 109

Figura 11: Rede de Pesquisadores do Colóquio Internacional sobre o Poder Local 112

Figura 12: Representação gráfica da centralidade de grau (degree), centralidade de intermediação (betweenness) e centralidade de autovetor (eigenvector) da Rede de Pesquisadores do Colóquio Internacional sobre o Poder Local 
Figura 14: Representação gráfica da centralidade de grau (degree), centralidade de intermediação (betweenness) e centralidade de autovetor (eigenvector) da Rede de Pesquisadores do EnAPG

Figura 15: Rede de Pesquisadores do EMAPEGS

Figura 16: Representação gráfica da centralidade de grau (degree), centralidade de intermediação (betweenness) e centralidade de autovetor (eigenvector) da Rede de Pesquisadores do EMAPEGS 125

Figura 17: Rede de Pesquisadores da Revista de Administração Pública (RAP) 129

Figura 18: Representação gráfica da centralidade de grau (degree) e centralidade de intermediação (betweenness) da Rede de Pesquisadores da Revista de Administração Pública (RAP)

Figura 19: Rede de Pesquisadores dos Cadernos EBAPE.BR 134

Figura 20: Representação gráfica da centralidade de grau (degree), centralidade de intermediação (betweenness) e centralidade de autovetor (eigenvector) da Rede de Pesquisadores dos Cadernos EBAPE.BR 135

Figura 21: Rede de Pesquisadores da Revista Organizações \& Sociedade (O\&S). 138 Figura 22: Representação gráfica da centralidade de grau (degree), centralidade de intermediação (betweenness) e centralidade de autovetor (eigenvector) da Rede de Pesquisadores da Revista Organizações \& Sociedade (O\&S) ............................................ 140

Figura 23: Rede de Pesquisadores dos Cadernos de Gestão Pública e Cidadania 144

Figura 24: Representação gráfica da centralidade de grau (degree), centralidade de intermediação (betweenness) e centralidade de autovetor (eigenvector) da Rede de Pesquisadores dos Cadernos de Gestão Pública e Cidadania 146

Figura 25: Rede de Pesquisadores da Administração Pública e Gestão Social (APGS) ........ 148 Figura 26: Representação gráfica da centralidade de grau (degree), centralidade de intermediação (betweenness) e centralidade de autovetor (eigenvector) da Rede de Pesquisadores da Administração Pública e Gestão Social (APGS) 150

Figura 27: Rede de Pesquisadores da NAU Social 153

Figura 28: Representação gráfica da centralidade de grau (degree), centralidade de intermediação (betweenness) e centralidade de autovetor (eigenvector) da Rede de Pesquisadores da NAU Social 155

Figura 29: Rede de Pesquisadores dos Cadernos de Gestão Social (CGS) 158 
Figura 30: Representação gráfica da centralidade de grau (degree), centralidade de intermediação (betweenness) e centralidade de autovetor (eigenvector) da Rede de Pesquisadores dos Cadernos de Gestão Social (CGS)........................................................ 160

Figura 31: Rede de Pesquisadores da Revista Interdisciplinar de Gestão Social (RIGS) ...... 163 Figura 32: Representação gráfica da centralidade de grau (degree) e centralidade de intermediação (betweenness) da Rede de Pesquisadores da Revista Interdisciplinar de Gestão Social (RIGS) 165

\section{BOX}

Box 1: Apontamentos históricos acerca da Gestão Social 47

Box 2: Algumas críticas à abordagem da Gestão Social 54 


\section{SUMÁRIO}

1. INTRODUÇÃ

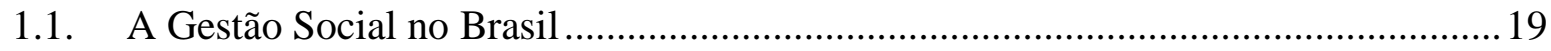

1.2. A Gestão Social no Campo de Públicas....................................................................... 19

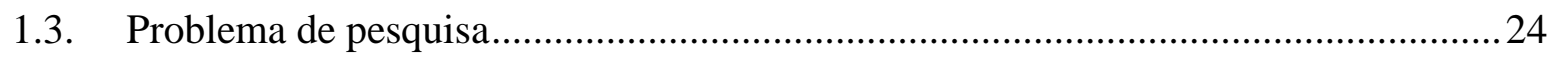

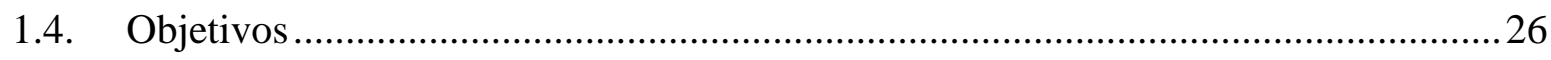

2. OPERACIONALIZAÇÃO CONCEITUAL E REVISÃO DA LITERATURA ..............28

2.1. Gênese e desenvolvimento da Gestão Social........................................................ 28

2.1.1. Principais definições em torno do termo Gestão Social ..................................... 30

2.2. Trajetória da pesquisa em Gestão Social .................................................................... 48

2.3. Organização acadêmica da Gestão Social no Brasil ...................................................55

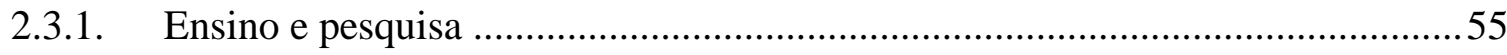

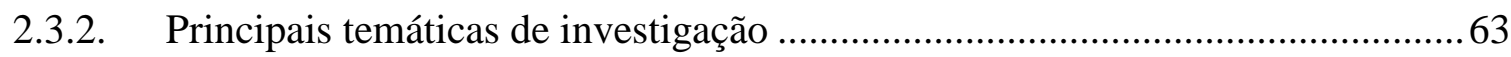

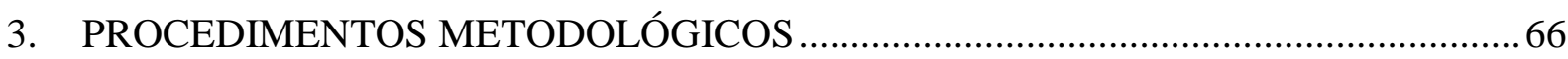

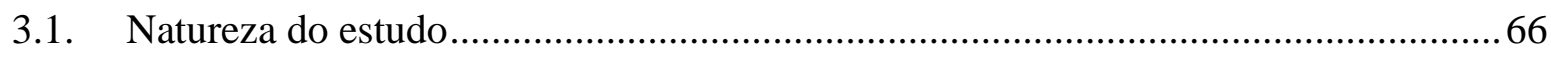

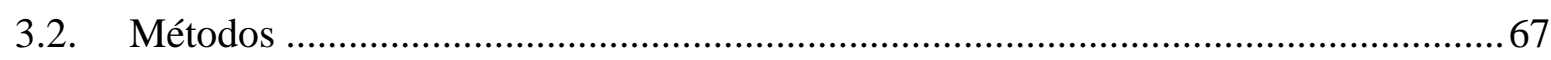

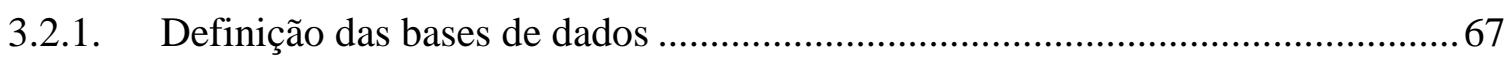

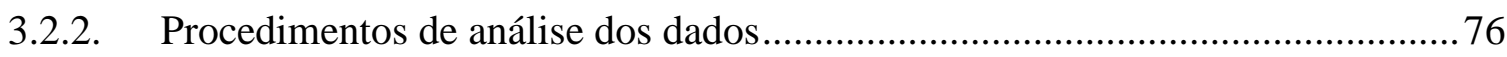

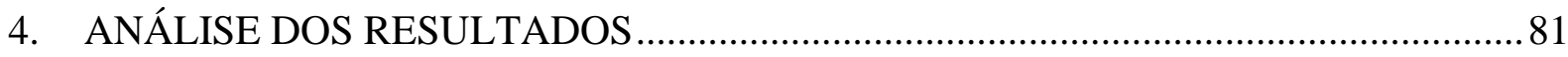

4.1. Rede de Pesquisadores de Gestão Social (RPGS) ............................................... 81

4.2. Rede de Pesquisadores do ENAPEGS ................................................................ 101

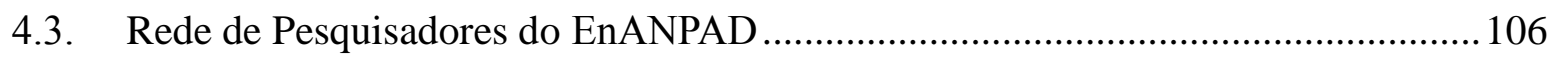

4.4. Rede de Pesquisadores do Colóquio Internacional sobre o Poder Local..................112

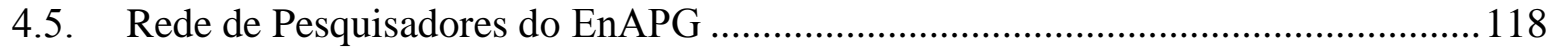

4.6. Rede de Pesquisadores do EMAPEGS ......................................................... 123

4.7. Rede de Pesquisadores da Revista de Administração Pública (RAP) .................... 128 
4.8. Rede de Pesquisadores dos Cadernos EBAPE.BR

4.9. Rede de Pesquisadores da Revista Organizações \& Sociedade (O\&S) .................. 138

4.10. Rede de Pesquisadores dos Cadernos de Gestão Pública e Cidadania.................. 143

4.11. Rede de Pesquisadores da Administração Pública e Gestão Social (APGS) ........ 148

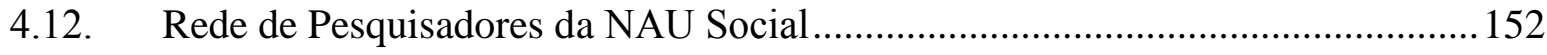

4.13. Rede de Pesquisadores dos Cadernos de Gestão Social.................................... 157

4.14. Rede de Pesquisadores da Revista Interdisciplinar de Gestão Social (RIGS) ..... 162

4.15. Considerações gerais sobre a análise dos resultados....................................... 167

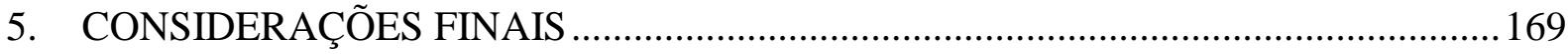

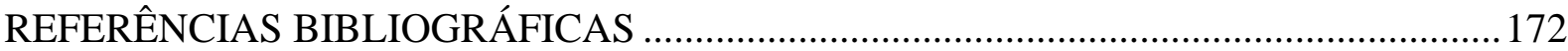

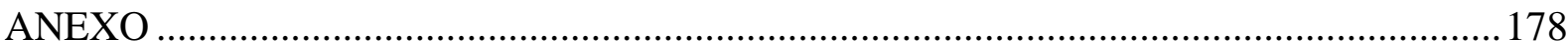




\section{INTRODUÇÃO}

\subsection{A Gestão Social no Brasil}

O campo da Gestão Social tem se desenvolvido no contexto brasileiro desde o período de redemocratização do país, tendo sido implementado como modelo alternativo de gestão pública pelos movimentos sociais, partidos de esquerda e organizações não-governamentais (PAES DE PAULA, 2005), bem como tornou-se objeto de estudo em programas de pósgraduação, centros de pesquisa, eventos e publicações (MENDONCA, GONCALVES-DIAS, JUNQUEIRA, 2012). Desde então, diversos pesquisadores têm se concentrado em buscar a definição do conceito de Gestão Social, além de pesquisar sobre experiências ocorridas e elaborar estudos teóricos sobre o campo em si.

Uma das tentativas de delimitação do campo da Gestão Social foi feita por Cançado, Tenório e Pereira (2011), em que os autores colocam que

\footnotetext{
a Gestão Social pode ser apresentada como a tomada de decisão coletiva, sem coerção, baseada na inteligibilidade da linguagem, na dialogicidade e no entendimento esclarecido como processo, na transparência como pressuposto e na emancipação enquanto fim último.
}

Araújo (2012) pontua que, embora diversos autores brasileiros tenham proposto diferentes conceitos para a Gestão Social, é possível identificar elementos comuns entre eles, como, por exemplo, "a forte presença de valores de democracia, participação, justiça, equidade e bem-estar social; a dialogicidade, horizontalidade e solidariedades nas relações; a atuação intersetorial e interorganizacional” (ARAÚJO, 2014).

\subsection{A Gestão Social no Campo de Públicas}

O Campo de Públicas é um conceito em construção que tem se moldado devido à atuação de professores, gestores acadêmicos e estudantes, por meio da realização de ações 
para debater tanto temas científicos quanto assuntos referentes à regulação e avaliação educacional (PIRES et al., 2014). A ideia de pano de fundo desse movimento, segundo Pires et al. (2014), é "um esforço político-acadêmico para diferenciar objetos e objetivos de cursos de graduação focados na gestão pública daqueles voltados para a administração de empresas".

Internacionalmente, o campo da administração pública formou-se há mais de um século nos EUA com o objetivo de preparar os servidores públicos para uma administração moderna. Naquela época, havia uma diferenciação entre administração pública e política que visava superar as práticas clientelistas e patrimonialistas então vigentes nos EUA. De acordo com Farah (2011), a separação entre administração e política acarretou a busca por princípios que fossem válidos para a administração de qualquer organização, seja ela pública ou privada. Esse movimento levou ao esvaziamento da dimensão pública da administração, gerando uma crise identitária da disciplina (FARAH, 2011). Essa dicotomia afetou o desenvolvimento da disciplina nas décadas seguintes, o segmentando em duas tendências: o fortalecimento do polo da política, reaproximando a administração pública da ciência política; e a consolidação da influência da ciência administrativa (FARAH, 2011).

A temática sobre políticas públicas pode ser notada, mesmo que de maneira incipiente, na década de 1950, no polo da ciência política. Isso porque a visão de que os administradores públicos apenas executavam as políticas públicas foi complementada com a ideia de que eles também participavam de sua formulação (FARAH, 2011). No período seguinte, final da década de 1960 e meados da década de 1970, surgiram escolas e cursos de análise de políticas públicas independentes das escolas de administração pública, com o objetivo de proporcionar uma formação diferenciada e orientada para o treinamento de analista de políticas públicas (FARAH, 2011). Segundo Souza (2003), a área de conhecimento (assim como a disciplina) de políticas públicas "surge no mundo acadêmico sem estabelecer relações com as bases teóricas sobre o papel do Estado, passando direto para a ênfase nos estudos sobre a ação dos governos" (SOUZA, 2003).

No início, a disciplina de administração pública era voltada para a formação de servidores públicos, restringindo-se, portanto, apenas à administração governamental. Entretanto, com o decorrer do tempo, a ideia de "público" foi expandida para além do Estado, atingindo organizações privadas e da sociedade civil engajadas na ampliação da participação dos cidadãos na formulação, implementação e controle das políticas públicas (FARAH, 2011). Segundo Farah (2011), “a disciplina administração pública precisou, portanto, 
reposicionar-se, de forma a dar conta desta nova complexidade, o que exigiu uma revisão também da abordagem analítica das políticas públicas, como apontam diversos atores”.

No Brasil, a disciplina de administração pública surgiu com o mesmo propósito dos EUA: formação de servidores públicos para uma administração pública moderna. Podemos apontar como marcos fundantes da disciplina no país a criação da Revista do Serviço Público em 1937, que visava a disseminação de ideias e princípios que orientariam a administração pública para a modernidade; e a criação do Departamento de Administração do Setor Público em 1938, órgão responsável pela criação de uma estrutura administrativa básica que pudesse operacionalizar esse novo modelo de administração proposto (FARAH, 2011).

Os primeiros cursos de graduação em administração pública no Brasil surgiram nos anos de 1950, no contexto da expansão de um Estado administrativo, dos ideais desenvolvimentistas do pós-guerra e da influência de assistência técnica norte-americana (FADUL et al., 2014). Nesse período, a gestão pública era entendida a partir do modelo weberiano, no qual as políticas públicas eram concebidas pela classe política e posteriormente executadas pela burocracia, ou seja, havia uma separação entre política e administração (FADUL et al., 2014). Entretanto, essa dicotomia foi amenizada nos Estados Unidos no período pós-1950 com o surgimento da abordagem da análise de políticas públicas, oriunda da ciência política. O mesmo não ocorreu no Brasil, pois no período da ditadura militar (19641985) houve uma sobrevalorização da tecnologia administrativa na gestão pública, acarretando a mimetização de técnicas e abordagens próprias da administração de empresas para a administração pública. Segundo Fadul et al. (2014), esse cenário contribuiu para a "vinculação (ou subordinação) institucional da formação acadêmica em administração pública à de administração de empresas no país, que diluiu a especificidade da administração pública e corroborou para o seu subdesenvolvimento disciplinar em nível nacional" (FADUL et al., 2014).

A inclusão da temática das políticas públicas no Brasil, assim como nos EUA, deu-se por volta de 1970, quando a Escola Brasileira de Administração Pública e de Empresas, da Fundação Getúlio Vargas (Ebape/FGV), deu início a um projeto de estudos denominado "Estudos sobre políticas governamentais", o qual foi publicado pela Revista de Administração Pública (RAP) no mesmo período (FARAH, 2011). Em 1973, a área de análise de políticas públicas foi incorporada ao currículo do curso de mestrado em administração pública da 
Ebape/FGV em consonância com os programas de mestrado e a influência que essa área estava tendo nos EUA.

Essa tendência começa a se modificar a partir do período da redemocratização do país e do processo de Reforma do Estado, em que o número de pesquisas em administração pública passa a crescer (FADUL et al., 2014). No entanto, a quantidade de cursos de graduação e pós-graduação em administração pública passa a aumentar somente a partir da década de 2000. É nesse contexto de renascimento da educação superior em administração pública e da "necessidade de se construir uma área de conhecimento multidisciplinar diferenciada e inovadora" (PIRES et al., 2014) que surge a ideia do Campo de Públicas.

O Campo de Públicas foi sendo construído por meio da atuação de professores, gestores acadêmicos e estudantes em dois principais foros: os Encontros Nacionais de Estudantes de Administração Pública (ENEAP) e os Fóruns de Professores e Coordenadores dos Cursos do Campo de Públicas (FP3CP). Durante a nona edição do ENEAP, que ocorreu em Balneário Camboriú, o IV Fórum de Coordenadores elaborou uma carta, a qual ficou conhecida como "Carta de Camboriú", que buscou delimitar as fronteiras epistemológicas do campo e impulsionar a definição e aprovação de Diretrizes Curriculares Nacionais (DCNs) para os Cursos do Campo Multidisciplinar de Formação Acadêmica em Administração Pública, Gestão Pública, Políticas Públicas, Gestão Social e Gestão de Políticas Públicas. Nessa carta foi proposto um diagrama para facilitar a compreensão do conceito de Campo de Públicas, que será reproduzido na sequência. 
Figura 1: Representação do Campo de Públicas

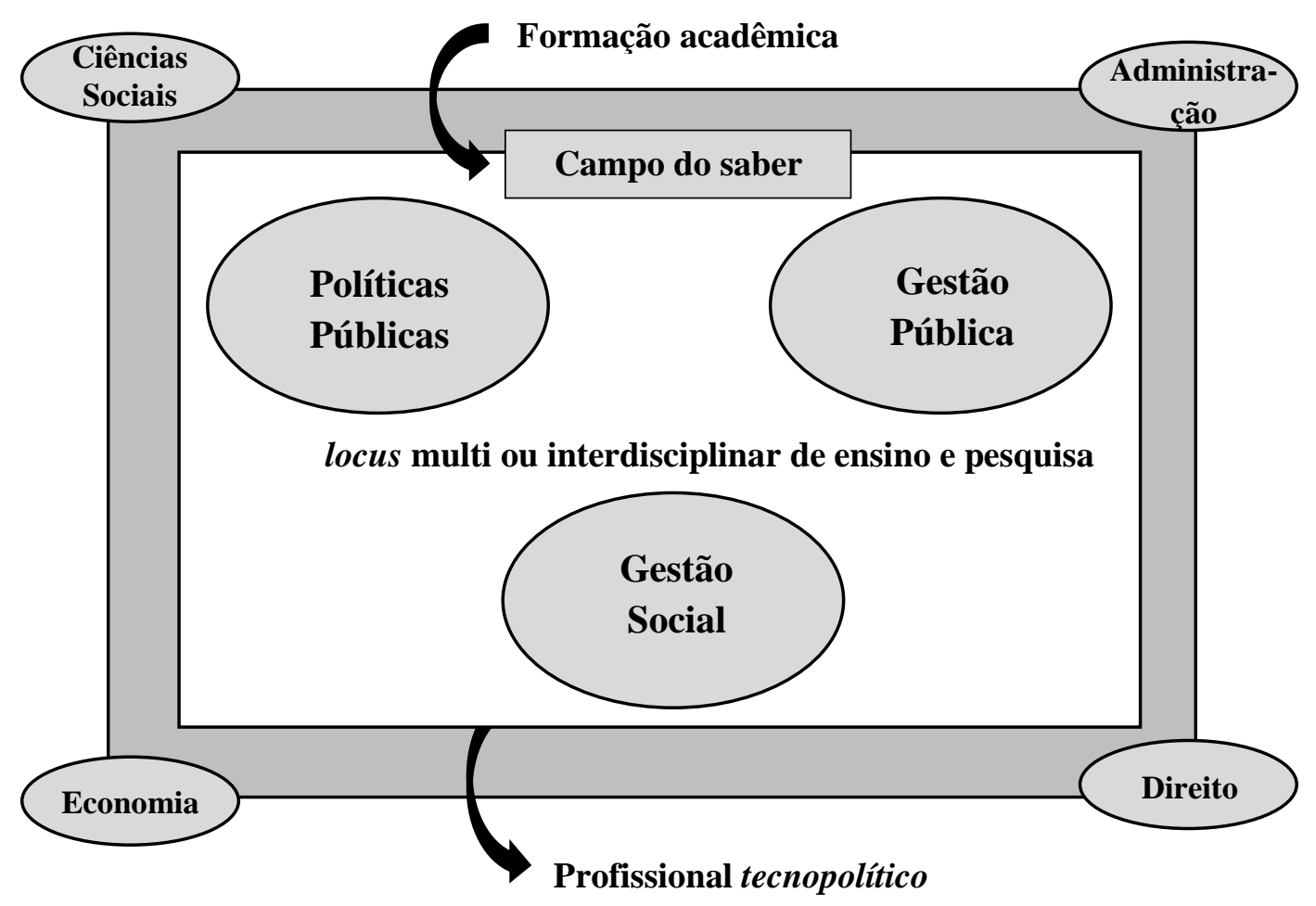

Fonte: Carta de Camboriú (2010)

Segundo a Carta de Camboriú (2010),

Em linhas gerais, a figura ilustra, tentativamente, a conformação do campo do saber de "públicas" no Brasil, a partir da confluência - multi ou interdisciplinar - das áreas de conhecimento em Administração, Ciência Sociais, Direito e Economia, as quais, segundo Mezzomo Keinert (1998), sobressaíram no decorrer do século XX na aplicação de seu referencial teórico para a formação acadêmica e produção científica em administração pública no país. Nas últimas décadas, o diálogo entre essas áreas de conhecimento gerou, nitidamente, um locus (na acepção de objeto de estudo, de formação acadêmica e de capacitação profissional) caracterizado pelo interesse público, repercutindo no surgimento de grupos de pesquisa em sub-campos como Políticas Públicas, Gestão Pública e Gestão Social, que, inclusive, originaram e sustentam programas de pós-graduação - nas grandes áreas de Ciências Humanas, Ciências Sociais Aplicadas e Multidisciplinar. Em nível de graduação, esse movimento ensejou nos últimos anos o (re)surgimento de bacharelados em Administração Pública, bem como a concepção de cursos - multi ou interdicisplinares - em Gestão Pública, Gestão de Políticas Públicas, Gestão Social e Políticas Públicas, cuja identidade coletiva é a formação acadêmica (e a profissiografia) tecnopolítica.

Portanto, esse novo campo pode ser compreendido como a confluência de três grandes campos do saber: Políticas Públicas, Gestão Pública e Gestão Social. As subáreas de Administração Pública e Políticas Públicas têm uma história no país desde meados do século 
XX, conforme tratado acima. Dessa forma, das três subáreas do Campo de Públicas, a subárea da Gestão Social tem seu desenvolvimento mais recente e sua institucionalização neste período justifica estudá-la para compreender sua conformação. Assim sendo, dentro desse conceito guarda-chuva que é o Campo de Públicas, esta pesquisa elegeu o campo da Gestão Social como foco.

A pesquisa "Gestão Social como campo do saber no Brasil: uma análise de sua produção científica pela modelagem de redes sociais (2005-2015)" visa complementar outras duas pesquisas que foram realizadas no âmbito do Programa de Pós-Graduação em Modelagem de Sistemas Complexos, também da Escola de Artes, Ciências e Humanidades $(\mathrm{EACH})$, da Universidade de São Paulo. As pesquisas tiveram os seguintes objetos de estudo: "A produção científica em Políticas Públicas no Brasil: uma análise sob a ótica de redes sociais", elaborada por Paula Trottmann; e "Uma análise do campo do saber em Administração Pública no Brasil (2000-2010) pela modelagem de redes sociais”, elaborada por Victor Corrêa Silva. Portanto, a realização de uma pesquisa que analise a rede de produção científica da Gestão Social completará a trilogia de trabalhos sobre a produção científica do Campo de Públicas, constituído pelas áreas de Administração Pública, Políticas Públicas e Gestão Social.

\subsection{Problema de pesquisa}

A pesquisa em Gestão Social no Brasil tem um histórico recente, conforme apontamos acima, datada do período de redemocratização do país, embora Paes de Paula (2005) tenha apontado que desde 1960 havia um movimento ligado à tradição mobilizatória brasileira, no qual a Igreja Católica atuou por meio das Comunidades Eclesiais de Base, levantando questões coletivas e se consolidando como espaço de participação e formação de lideranças populares. Para Paes de Paula (2005), esse movimento que buscava a ampliação da participação cidadã, a discussão de problemas coletivos de cunho social e garantia de direitos atingiu seu ápice na década de 1980. Nesse período surgiram as primeiras experiências que buscavam romper com a relação centralizada e autoritária entre Estado e sociedade (PAES DE PAULA, 2005). Contudo, foi a partir dos anos de 1990 que as pesquisas sobre Gestão Social 
ganharam força, através da criação de centros de pesquisa e eventos que passaram a discutir o tema (CANÇADO, 2011).

De acordo com Boullosa e Schommer (2009), a diversidade dessas experiências provocou uma ambiguidade conceitual, pois elas partilhavam "não o pertencimento a campos de saber estruturados, mas sim o não pertencimento ao campo da gestão pública ou privada. [...] Cada uma dessas experiências interpretava Gestão Social de modo contextual" (BOULLOSA E SCHOMMER, 2009). Portanto, por se tratar de um constructo polissêmico (ARAÚJO, 2014) e de um campo com um desenvolvimento recente, é importante que sejam realizados o mapeamento e a construção da rede de produção científica do campo de Gestão Social, visando a identificação das principais características predominantes do campo associadas à formação acadêmica e vinculação institucional, além da concentração temática e da dinâmica de relacionamento dos pesquisadores. A partir dessa análise, será possível verificar a evolução do campo por meio da rede de produção científica na última década, verificando seu desenvolvimento e peculiaridades, além de contribuir com o debate em torno da construção da identidade da área de pesquisa em Gestão Social.

Alguns autores já empreenderam esforços para realizar estudos bibliométricos no campo da Gestão Social, como Hocayen-da-Silva, Rossoni e Ferreira Junior (2008), que traçaram um quadro geral da produção científica em administração pública e Gestão Social a partir da análise dos anais do Encontro da Associação Nacional de Pós-Graduação e Pesquisa em Administração (EnANPAD), entre os anos de 2000 e 2005. Cançado et al (2011) buscaram analisar e discutir a produção específica sobre Gestão Social nas edições de 2007 a 2010 do Encontro Nacional de Pesquisadores em Gestão Social (ENAPEGS), visando compreender como vem sendo construído o entendimento sobre a temática nesse espaço. Podemos apontar também o estudo de Cançado e Pinheiro (2014), que mapeou o entendimento do termo Gestão Social nos ENAPEGSs de 2007 a 2013 e comparou com os resultados de Cançado et al (2011), citado acima, e com Cançado (2011), que procurou esboçar uma primeira aproximação de construção dos fundamentos teórico-metodológicos da Gestão Social e uma primeira delimitação dessa área enquanto campo do conhecimento científico, através da análise na produção acadêmica na área. Ainda podemos citar Iizuka e Junqueira (2013), que analisaram a produção acadêmica com a temática da Gestão Social nos ENAPEGS de 2007 a 2012; Grangeiro, Pinto e Vinhas (2013), que fizeram uma análise quantitativa das redes sociotécnicas de pesquisadores da área de Gestão Social, por meio da análise dos trabalhos apresentados nos ENAPEGS de 2007 a 2011; Anjos (2014), que 
procurou identificar os procedimentos metodológicos utilizados na produção científica sobre Gestão Social nos eventos EnANPAD e EnAPG no período de 2001 a 2011; e Borges et al (2012), que analisaram os estudos realizados no Brasil sobre o tema Gestão Social, através de busca na produção científica publicada nos principais periódicos da área, considerando o período entre 2001 e 2011. Podemos notar que a maioria dos trabalhos apontados analisa o campo da Gestão Social a partir dos trabalhos apresentados no Encontro Nacional de Pesquisadores em Gestão Social (ENAPEGS) ou faz análises apenas quantitativas da produção científica. Esses são apenas alguns trabalhos que tratam a Gestão Social do ponto de vista bibliométrico, portanto, não esgotam a análise do tema.

O estudo que mais se assemelha aos objetivos do presente trabalho é o de Borges et al (2012). Contudo, a análise empreendida pelos autores contempla o período de 2001 a 2011, havendo um déficit de cinco anos até o período atual.

Dessa forma, o presente trabalho busca complementar os estudos realizados anteriormente e expandir o universo analisado para além do Encontro Nacional de Pesquisadores em Gestão Social (ENAPEGS), contribuindo para o esboço do diagnóstico do que o campo da Gestão Social no Brasil atualmente.

\subsection{Objetivos}

Esta dissertação de mestrado aponta como objetivo geral o mapeamento e a construção da rede de produção científica do campo do saber em Gestão Social na última década (20052015), adotando como unidade de análise os autores e artigos do campo. Dentre os objetivos específicos, elencamos:

- Identificar, a partir da análise dos autores mais prolíficos, as principais características predominantes do campo de Gestão Social, associadas à formação acadêmica e vinculação institucional, concentração temática e dinâmica de relacionamento dos pesquisadores;

- Analisar a evolução do campo por meio da rede de produção científica na última década, verificando seu desenvolvimento e peculiaridades; 
- Contribuir com o debate em torno da construção da identidade da área de pesquisa em Gestão Social.

Para atingir esses objetivos, o trabalho está estruturado com base em quatro capítulos, a saber: operacionalização conceitual e revisão da literatura, em que serão tratados os conceitos de Gestão Social e seu desenvolvimento prático e acadêmico no Brasil; procedimentos metodológicos, que trará o detalhamento das etapas de planejamento e execução da pesquisa; descrição e análise dos resultados, onde os resultados serão apresentados de duas formas distintas: consolidado e segmentado por evento e periódico; e as considerações finais. 


\section{OPERACIONALIZAÇÃO CONCEITUAL E REVISÃO DA LITERATURA}

Neste capítulo apresentaremos um embasamento conceitual e a organização acadêmica da Gestão Social no Brasil. Devemos ressaltar que optamos por fazer um recorte na revisão da literatura, já que há outras perspectivas e áreas que tratam sobre a Gestão Social. As sessões tratarão de: i) gênese e desenvolvimento da Gestão Social, em que apontaremos a origem do campo; ii) principais definições em torno do termo Gestão Social, em que trataremos as principais perspectivas sobre a área; iii) trajetória da pesquisa em Gestão Social, em que apresentaremos a constituição da Gestão Social no Brasil, a partir da descrição de três gerações; iv) organização acadêmica da Gestão Social no Brasil, subdividindo-se em dois itens, a) ensino e pesquisa e b) principais temáticas de investigação.

\subsection{Gênese e desenvolvimento da Gestão Social}

Ao analisarmos o panorama de reformas ocorridas na América Latina na década de 1990, observamos que os países agiram de acordo com duas tendências em relação à crise de 1980: uma delas estava ligada a demandas sociais geradas pelos processos de redemocratização e a outra se relacionava ao ajuste estrutural do aparato estatal e à inserção da América Latina em uma nova ordem internacional (CENTRO LATINOAMERICANO DE ADMINISTRACIÓN PARA EL DESARROLLO, 2010). Segundo Centro Latinoamericano de Administración para el Desarrollo (2010), a primeira tendência impulsionou movimentos de maior participação popular, a busca pela profissionalização do serviço público e, sobretudo, uma maior democratização do jogo político-eleitoral. Já a segunda tendência, que foi chamada de primeira rodada de reformas, é marcada pela redução do tamanho do aparelho estatal, pelas privatizações, pela abertura comercial e pela modernização da gestão, caracterizada pela racionalização de procedimentos e reformulação do processo orçamentário.

No Brasil, Paes de Paula (2005) também aponta duas direções que corroboram as tendências colocadas pelo Centro Latinoamericano de Administración para el Desarrollo (2010). Para a autora, durante o período de redemocratização, havia dois projetos políticos em disputa: um com referências à vertente gerencial e outro ligado à vertente societal. Embora o 
modelo escolhido para inspirar a reforma do Estado realizada pelo governo de Fernando Henrique Cardoso tenha sido o modelo gerencial,

\begin{abstract}
não havia no cenário político uma visão unívoca de reforma, pois também estava em curso um novo paradigma reformista: o estado-novíssimo-movimento-social, que rearticula o Estado e a sociedade, combinando a democracia representativa e a participativa (SOUZA SANTOS, 1999 apud PAES DE PAULA, 2005).
\end{abstract}

Essa orientação foi defendida por intelectuais de esquerda e de membros do Partido dos Trabalhadores, que também destacavam a importância da criação de uma esfera pública não-estatal e da criação de espaços públicos de deliberação e negociação. Para Paes de Paula (2005), “esse conceito de esfera pública não-estatal envolve a elaboração de novos formatos institucionais que possibilitem a co-gestão e a participação dos cidadãos nas decisões públicas". Araújo (2012) relata que, a partir de 1990, a crise mundial afetou o sistema de proteção social brasileiro, devido à escassez de recursos; provocou uma pressão para assegurar a diminuição do papel do Estado; e incentivou a construção de novas relações entre Estado e sociedade civil. De acordo com Araújo (2012), "nesse contexto, tornam-se latentes as discussões sobre a ampliação do espaço público, democracia e cidadania, enfatizando dilemas sobre a privatização, publicização, focalização e universalização da política social".

A discussão sobre Gestão Social no meio acadêmico também data do mesmo período, meados da década de 1990, quando pesquisadores viram na Gestão Social uma "possibilidade inovadora de pesquisa e ensino no campo da Administração" (ARAÚJO, 2012). Esse movimento inicia-se no âmbito do Programa de Estudos em Gestão Social da Escola Brasileira de Administração Pública e de Empresas da Fundação Getúlio Vargas PEGS/EBAPE/FGV e expande-se para a Universidade Federal do Rio Grande do Sul UFRGS, Universidade Federal da Bahia - UFBA, Universidade de São Paulo - USP e Pontifícia Universidade Católica de São Paulo - PUC-SP (CANÇADO; PEREIRA; TENÓRIO, 2013). De acordo com Cançado (2014), todas as instituições, exceto a UFBA, iniciaram seus estudos em Gestão Social em centros de estudos que tratavam da temática do terceiro setor. Inicialmente o termo era utilizado para designar políticas sociais, contudo, com a ampliação para outras instituições, "Gestão Social” também foi usada como sinônimo de gestão de organizações do terceiro setor, carregando a ideia de uma participação democrática 
e participativa. Segundo Cançado (2014), “esta visão, entretanto, se amplia na academia e pode-se dizer que a Gestão Social, tal como discutida no Brasil, é um constructo autóctone".

O termo Gestão Social está em construção no Brasil e, de acordo com Pinho (2009), embora não haja consenso sobre o que o termo representa, esse tipo de gestão tem sido implantado e se afirmado na prática. Em uma revisão bibliográfica, Cançado, Pereira e Tenório (2013) identificaram diversos entendimentos sobre o que é Gestão Social, dentre eles: gestão democrática ou participativa de políticas públicas sociais, gestão democrática do terceiro setor ou de ONGs, gestão ambiental, gestão democrática do desenvolvimento territorial e responsabilidade socioambiental. Segundo Cançado (2014)

esse debate, por outro lado, caminhou no sentido de estabelecer uma polissemia acerca da terminologia, a ponto de alguns autores como França Filho (2003) e Cançado, Pereira e Tenório (2011) temerem pela sua banalização, pois tudo que não era gestão tradicional poderia ser enquadrado como Gestão Social, diminuindo as possibilidades de desenvolvimento do próprio constructo. (CANÇADO, 2014)

\subsubsection{Principais definições em torno do termo Gestão Social}

Diversos pesquisadores têm tratado a questão da Gestão Social, muitas vezes sob perspectivas distintas e conceitos divergentes do termo, resultando em uma polissemia, conforme apontado acima. A seguir apresentaremos alguns autores que trataram da Gestão Social.

Tenório (2010) relata que a preocupação com o tema da Gestão Social teve início em 1992, durante o "Seminário Iberoamericano de Desarrollo de Profesores en Gerencia Social”, realizado na Bolívia. No entanto, o autor destaca que o conceito de Gestão Social tratava de questões que atualmente denominamos de terceiro setor. Posteriormente, em 1993, foi publicado um livro que buscava sistematizar o tema da Gestão Social, intitulado "Pobreza: un tema impostergable. Nuevas respuestas a nivel mundial", organizado por Bernardo Kliksberg e que pode ser considerado o primeiro texto da América Latina com este objetivo. Em 1997, Tenório participa do "Curso de Directivos em Diseño y Gestión de 
Políticas y Programas Sociales", promovido pelo Instituto Interamericano para o Desenvolvimento Social (INDES), do Banco Interamericano de Desenvolvimento (BID), e amplia e aprofunda sua visão sobre Gestão Social, desvinculando a ideia de que Gestão Social tratava apenas de políticas sociais. Após reflexões e amadurecimento, o autor propõe que Gestão Social pode ser entendida como

o processo gerencial dialógico no qual a autoridade decisória é compartilhada entre os participantes da ação (ação que possa ocorrer em qualquer tipo de sistema social - público, privado ou de organizações não-governamentais). O adjetivo social qualificando o substantivo gestão será entendido como o espaço privilegiado de relações sociais em que todos têm o direito à fala, sem nenhum tipo de coação. (TENÓRIO, 2005)

Tenório (1998) apresenta o conceito de Gestão Social a partir de pesquisas e experiências práticas realizadas pelo Programa de Estudos em Gestão Social (PEGS), da EBAPE/FGV. No âmbito deste programa, estuda-se a relação entre Estado e sociedade e capital e trabalho. No entanto, os estudos invertem a ordem dos termos que é normalmente utilizada para sociedade-estado e trabalho-capital, com intuito de colocar a cidadania como centro dessas relações. Segundo Tenório (1998), “o cidadão é o sujeito privilegiado de vocalização daquilo que interessa à sociedade nas demandas ao Estado e daquilo que interessa ao trabalhador na interação com o capital".

O autor discute o conceito de Gestão Social sob a luz da teoria crítica e destaca alguns pontos que justificam essa escolha. O primeiro deles é que teorias críticas podem ser tomadas como guia para as ações humanas, uma vez que buscam o esclarecimento entre os indivíduos que as defendem e possuem natureza emancipatória. Outros elementos que Tenório (1998) destaca é que as teorias críticas são formas de conhecimento e que buscam ser reflexivas (Geuss, 1988 apud Tenório, 1998).

Tenório (1998) segue o raciocínio retomando ideias do pensador alemão Jürgen Habermas, o qual acreditava que a razão instrumental dificultava a autonomia social dos indivíduos e, para superar tal obstáculo, "propõe um paradigma teórico-social que implemente a razão a partir do consenso alcançado por uma ação do tipo social comunicativa, em vez de uma ação social do tipo estratégica" (TENÓRIO, 1998). Tenório (1998) aponta que a ação estratégica é baseada na relação entre atores que analisam e direcionam suas ações visando o 
alcance de seus objetivos. Já a ação comunicativa é uma ação em que indivíduos buscam a razão por meio do entendimento, podendo ser considerada, portanto, uma antítese à ação estratégica. Essas tipologias de ação, oriundas dos estudos de Habermas, têm papel importante na origem dos conceitos de gestão estratégica e Gestão Social.

Conforme colocado acima, Tenório (1998) apresenta o conceito de gestão estratégica e, posteriormente, o conceito de Gestão Social, com o intuito de esclarecer as diferenças entre eles. De acordo com Tenório (1998), a gestão estratégica

é um tipo de ação social utilitarista, fundada no cálculo de meios e fins e implementada através da interação de duas ou mais pessoas, na qual uma delas tem autoridade formal sobre a(s) outra(s). [...] É uma combinação de competência técnica com atribuição hierárquica, o que produz a substância do comportamento tecnocrático (TENÓRIO, 1998).

O autor aponta, então, que a gestão estratégica tem como elementos principais: a ação social utilitarista, a hierarquia entre atores e a questão da competência técnica. A combinação desses fatores gera o comportamento baseado na tecnocracia, que para Tenório (1998)

é um fenômeno elitista que resulta da projeção da racionalidade instrumental sobre a gestão do Estado e/ou organização sob a epistemologia da teoria tradicional. Por se utilizar da ação gerencial do tipo monológica, ela é autoritária, na medida em que substitui a ideia de associação de indivíduos livres e iguais pela ideia de uma sociedade isenta de sujeitos.

O contraponto desse conceito de gestão estratégica é o conceito de Gestão Social, que, segundo Tenório (1998), “tenta substituir a gestão tecnoburocrática, monológica, por um gerenciamento mais participativo, dialógico, no qual o processo decisório é exercido por meio de diferentes sujeitos sociais". Podemos relacionar o conceito de Gestão Social ao conceito de ação comunicativa evocado acima, que dizia que a razão seria buscada por meio do entendimento entre os sujeitos. Dessa forma,

no contexto da Gestão Social orientada pela racionalidade comunicativa, os atores, ao fazerem suas propostas, não podem impor suas pretensões de validade sem que 
haja um acordo alcançado comunicativamente no qual todos os participantes exponham suas argumentações. (TENÓRIO, 1998).

Tenório $(1998,2005)$ também associa o termo Gestão Social ao termo cidadania deliberativa, que, segundo o autor, significa que "a legitimidade das decisões políticas deve ter origem em processos de discussão, orientados pelos princípios da inclusão, do pluralismo, da igualdade participativa, da autonomia e do bem comum" (TENÓRIO, 2005).

Outra autora que estuda a questão da Gestão Social é Fischer (2002), que propõe uma caracterização preliminar da gestão do desenvolvimento social como

um processo de mediação transformador que: articula múltiplas escalas de poder individual e societal; trabalha a identidade de processos, refletindo e criando pautas culturais; coordena interorganizações eficazes; promove ação e aprendizagem coletivas; comunica-se e difunde resultados; presta contas à sociedade; reavalia e recria estratégias, tendo por processo, alvo e motor, o desenvolvimento, considerando dimensões tangíveis e intangíveis, objetivas e subjetivas, que conformam organizações complexas e instituições (FISCHER, 2002)

Fischer (2002) aborda inicialmente a questão da Gestão Social por meio do conceito de desenvolvimento e poder local. A autora destaca que, na década de 1990, devido aos processos de globalização e ajustes econômicos, houve uma padronização do entendimento de desenvolvimento e a tendência de se pensá-lo sob a ótica do território. Portanto, a análise de poderes locais emerge como uma temática importante a ser debatida. De acordo com Fischer (2002), esse fenômeno "remete às relações de forças, por meio das quais se processam alianças e conflitos entre os atores sociais, bem como à formação de identidades e práticas de gestão específicas". Nesse contexto, Fischer (2002) traz a ideia de interorganizações que se formam de acordo com interesses, recursos e valores convergentes; buscam articular sociedade, Estado e mercado; têm a cidade como ponto de confluência; e lideram o processo de desenvolvimento local. A autora também aponta que nessa conjuntura a gestão tradicional é sobreposta por formas alternativas de gestão e novos desenhos organizacionais, conforme ela descreve abaixo 
circunscrevendo o conceito à rua, ao bairro ou mesmo à cidade. O universo de análise é mais amplo e abstrato, podendo estar relacionado a várias escalas de poder, consideradas isoladamente ou em conjunto, em um ou mais territórios (FISCHER, 2002)

A questão do desenvolvimento sofreu um processo de mutação ao longo dos anos. Nas décadas de 1950 e 1960, o Estado tinha papel protagonista nas ações desenvolvimentistas, mantendo um padrão de relações vertical. Nos anos de 1970, a tendência era unir planejamento e desenvolvimento, integrando questões econômicas e sociais. Na década de 1980, a ideia do desenvolvimento foi engolida pela crise econômica mundial, havendo espaços apenas para os ajustes econômicos. Já na década de 1990, verifica-se uma ênfase na questão da transformação e, nos anos seguintes, o mote foi o desenvolvimento integrado, ou seja, incorporaram-se as dimensões sociais e ambientais ao conceito. No Brasil, o desenvolvimento local pode ser verificado nas décadas de 1960 a 1980 com a atuação dos movimentos sociais e o surgimento das organizações não-governamentais, que possuíam "formas e estilos de intervenção ou, melhor dito, de gestão de programas e projetos de caráter associativo que se propunham a melhorar as condições de vida e democratizar a sociedade local" (FISCHER, 2002).

De acordo com Fischer (2002), há dois sentidos e significados de desenvolvimento: orientação para a competição e orientação para cooperação ou solidariedade. O primeiro deles, voltado para a competição, tem ênfase econômica e os atores dessa lógica são

governos, empresas, comunidades organizadas e redes produtivas, constituindo interorganizações configuradas, como o chamado 'entorno territorial inovador', com seus bens tangíveis e intangíveis, suas comunidades de interesse, a tecnologia e a informação (FISCHER, 2002).

As ações de desenvolvimento, segundo a orientação para a cooperação ou solidariedade, têm como pano de fundo as ideias de qualidade e cidadania e seguem alguns preceitos como

inclusão plena de setores marginalizados na produção e no usufruto dos resultados, não rejeitando a ideia de desenvolvimento econômico, mas impondo-lhe limites e subordinando-a aos imperativos não-econômicos; privilegiam a escala local, tanto 
no objeto quanto na ação social; salientam as formas de produção não-capitalista e estratégias econômicas autônomas, com tecnologias apropriadas. (Santos e Silveira, 2001 apud Fischer, 2002).

Fischer (2002) faz cinco proposições que identificam alguns processos e paradoxos do campo da gestão do desenvolvimento social. A primeira proposição diz

\begin{abstract}
A gestão do desenvolvimento social é um processo de mediação que articula múltiplos níveis de poder individual e social. Sendo um processo social e envolvendo negociação de significados sobre O QUE deve ser feito, POR QUE e PARA QUEM, a gestão não é uma função exercida apenas por um gestor, mas por um coletivo que pode atuar em grau maior ou menor de simetria/assimetria e delegação, o que traz uma carga potencial de conflito de interesses entre atores envolvidos e entre escalas de poder. (FISCHER, 2002)
\end{abstract}

De acordo com Fischer (2002), um traço marcante da década de 1990 é a transição de um modelo de gestão governamental baseado no protagonismo do Estado para um modelo "policêntrico", no qual que mais atores foram incorporados ao processo político e a participação popular é valorizada em todo o ciclo da política pública, desde a concepção até a avaliação.

A segunda proposição diz que "a gestão do desenvolvimento social é um campo de conhecimento e espaço de práticas híbrido e contraditório. A cooperação não exclui a competição; a competitividade pressupõe articulações, alianças e pactos" (FISCHER, 2002). Fischer (2002) destaca a existência de conflitos de interesses e percepções nesse processo, e que são "experiências de ruptura e de construção de novos paradigmas do agir social" (FISCHER, 2002).

A terceira proposição diz que a gestão do desenvolvimento social deve atender aos princípios da eficiência e eficácia e ser orientada por valores e pela ética da responsabilidade (FISCHER, 2002). A quarta proposição traz a ideia de que

A gestão do desenvolvimento social é gestão, também, de redes, de relações sociais, mutáveis e emergentes, afetadas por estilos de pessoas e comportamento, pela história do gestor, pela capacidade de interação e por toda a subjetividade presente nas relações humanas. 
E, por fim, a quinta proposição destaca o fator contextual

A gestão do desenvolvimento social é um processo embebido em contextos culturais que o conformam e para os quais contribui, refletindo e transformando esses contextos de forma tangível e intangível. O gestor social é gestor do simbólico e do valorativo, especialmente quando se trata de culturas locais e da construção de identidades.

Fischer (2002) coloca a importância de se construir um mapa que busque o sentido e o significado do campo da gestão do desenvolvimento social e permita compreendê-lo "como processo de mediação entre escalas de poder e lógicas sociais e contribua para a melhoria da gestão das organizações e interorganizações contemporâneas” (FISCHER, 2002).

Outra perspectiva conceitual é a de Boullosa e Schommer (2008), que apontam a expansão do termo Gestão Social para além da esfera acadêmica, alcançando discursos gerenciais e agendas governamentais. A expressão, que era comumente usada para denominar práticas sociais orientadas para cidadania corporativa ou de responsabilidade social empresarial, sejam elas do Estado, sociedade civil ou mercado - "parece assumir um progressivo caráter de solidez, passando a representar um modo especial de problematizar realidades sociointeracionais complexas e, sobretudo, de geri-las." (BOULLOSA e SCHOMMER, 2008). Para as autoras, a ideia de Gestão Social estabelece novas formas de relação entre Estado e sociedade. Segundo Boullosa e Schommer (2008),

\footnotetext{
o processo de construção da Gestão Social como alternativa de governança fundamenta-se no propósito de promover avanços nas práticas de gestão para a democratização nas relações sociais, por meio de práticas participativas e de engajamento nas decisões e práticas, em modelos decisórios de baixo para cima (bottom-up), privilegiando a dimensão dialógica e relacional da gestão (TENÓRIO, 2002;2004). Ao contrapor-se a modos de gestão fundamentados em hierarquia, controle e racionalização, a Gestão Social manifestaria um de seus potenciais de inovação.
}

Boullosa e Schommer (2008) apontam que esse caráter de inovação foi percebido por variados atores que identificaram na Gestão Social um processo "suficientemente amplo para acolher diferentes experiências criativas de gestão territorialmente contextualizadas/localizadas" (BOULLOSA e SCHOMMER, 2008). Portanto, 
a Gestão Social podia ser vista como um construto estratégico capaz de dar sentido, e importância, a experiências de gestão até então dispersas (ou que corriam o risco de dispersão). A Gestão Social passa, então, a satisfazer um certo vazio de etiquetagem (labeling) (BOULLOSA e SCHOMMER, 2008)

No entanto, Boullosa e Schommer (2008) apontam que, ao passo que a Gestão Social foi capaz de "etiquetar" e agrupar experiências até então dispersas, sofreu um processo de institucionalização que fazia com que essa capacidade de buscar experiências inovadoras se arrefecesse, dando espaço para representar a si mesma. Nas palavras de Boullosa e Schommer (2008), “ao que parece, a Gestão Social acabou sofrendo, em sua própria dinâmica de construção, um processo de inversão de significados, passando de índice a ícone”. De acordo com Boullosa e Schommer (2009), esse processo se deu no contexto da redemocratização, marcado pela promulgação da Constituição Federal de 1988, que conferia maior autonomia aos municípios; promovia a expansão da ideia de terceiro setor; abria espaço para mobilização e articulação de movimentos sociais e da sociedade civil; e possibilitava outros processos sociopolíticos que tinham como embasamento "novas matrizes interpretativas", como por exemplo, a difusão de experiências da Agenda 21 (BOULLOSA e SCHOMMER, 2008).

Nesse contexto, iniciaram-se as tentativas de sintetizar o conceito e promover reflexões sobre este novo campo. Porém, a variedade de experiências que foram acolhidas no conceito guarda-chuva "Gestão Social" provocou uma ambiguidade conceitual. Havia consenso sobre o que não era Gestão Social, mas havia dificuldade em se dizer o que era a Gestão Social. Segundo Boullosa e Schommer (2009)

o progressivo reconhecimento da Gestão Social como campo agregador de experiências que mobilizavam diferentes atores, por setores de governos federal, estadual e local, consolidava a busca pela democratização das decisões, mas, ate então, sem buscar a uniformização de tais experiências.

No entanto, nesse processo de construção de uma etiqueta que fosse capaz de contemplar a diversidade de setores, atores, práticas e termos, a Gestão Social foi uma alternativa viável e bem aceita. Contudo, ela passa "a ser confrontada com a necessidade de modelizar-se" (BOULLOSA e SCHOMMER, 2008), o que origina duas tensões: dificuldade 
em definir o construto e "a segunda, diz respeito à assunção da Gestão Social como episódio mais eloquente de um episódio de inovação que interessa a todo o âmbito das políticas sociais no Brasil” (BOULLOSA e SCHOMMER, 2008). Boullosa e Schommer (2009) apresentam um modelo de interpretação do processo de institucionalização da Gestão Social, destacando quatro momentos. O primeiro momento é marcado pela diversidade de experiências de gestão dispersas, mas, com alguns elementos comuns, como o objetivo prioritariamente social, a valorização da participação e do diálogo e a diferenciação dos modelos tradicionais de gestão. No segundo momento, observa-se uma identificação entre as experiências anteriormente dispersas e a posterior articulação entre elas. No terceiro momento, as características comuns entre as experiências passam a ser vistas como elementos de um novo modo de gestão, o qual passa a ser denominado Gestão Social. E, por fim, no quarto momento, é possível identificar determinado grau de institucionalização e modelização.

Boullosa e Schommer (2009) atentam que é necessária uma reflexão sobre o processo precoce de institucionalização da Gestão Social, com o objetivo de não torná-la "cristalizada e resistente à criatividade, à aprendizagem, à mudança" (BOULLOSA e SCHOMMER, 2008) e que isso "iniba seu potencial de constituir-se, de fato, como alternativa a modos de gestão opressivos, controladores e homogeneizadores das pessoas, das organizações e da sociedade" (BOULLOSA e SCHOMMER, 2008).

Podemos destacar também a perspectiva de França Filho (2008), que diz que a Gestão Social configura-se como espaço de atuação da sociedade civil, sendo, portanto, uma esfera pública não estatal. A Gestão Social é o modo de gestão praticado por organizações que não são nem do mercado nem do Estado, porém, muitas vezes, mantêm relações de parceria com essas esferas para implantação e execução de determinados projetos. O autor também destaca que essas organizações não possuem objetivos econômicos, sendo que estes se configuram apenas como um meio para o atingimento da meta principal, que pode estar ligada a cultura, política ou ecologia, de acordo com a natureza de atuação de cada organização (FRANÇA FILHO, 2008).

França Filho (2008) aponta que o termo Gestão Social vinha sendo largamente utilizado para denominar práticas sociais oriundas não somente da esfera governamental, mas de organizações não governamentais e até de empresas que passaram a ter preocupação em relação a sua responsabilidade social. O autor destaca que a expansão do uso do termo Gestão Social ocasionou sua própria "banalização", assinalando a necessidade de apuração do 
conceito. Outro fator que França Filho (2008) indica como impulsionador dessa expansão foi "a própria ascensão da discussão sobre o terceiro setor que chama atenção para o papel de organizações privadas atuando com objetivos públicos” (FRANÇA FILHO, 2008).

França Filho (2008) propõe que a Gestão Social seja pensada também pela ótica de processo e não apenas por sua finalidade. Partindo desse ponto de vista, ele questiona qual gestão não é social, haja vista que não há gestão sem o relacionamento entre pessoas. Segundo o autor, "toda gestão supõe, portanto, uma dimensão necessariamente social, ou poderíamos ainda chamar interacional, o que torna redundante uma formulação do tipo 'Gestão Social'” (FRANÇA FILHO, 2008).

O autor sugere dois níveis de análise ou de percepção da Gestão Social: um nível societário, que a identifica a uma problemática de sociedade; e um nível organizacional, aquele que a associa a uma modalidade específica de gestão. Em relação ao primeiro nível, a Gestão Social é entendida como gestão das demandas e necessidades do social, o que pode ter alguma sobreposição com o estudo da gestão pública pela ótica sociocêntrica das políticas públicas. A inovação trazida pela Gestão Social é que a gestão das demandas e necessidade do social pode ser feita além da esfera estatal, através da atuação da sociedade por meio de autoorganização e práticas associativas (FRANÇA FILHO, 2008). Sobre o outro nível de análise, o qual ele chamou de organizacional, pontua que a Gestão Social se diferencia de outras duas formas de gestão: a gestão estratégica ou privada e a gestão pública. Para França Filho (2008), a gestão estratégica é aquela praticada por organizações atuantes no mercado, as quais orientam suas ações para o atingimento de metas, puramente econômicas, preocupando-se mais com sua capacidade em atingir determinado fim do que com a qualidade das suas ações, remetendo, neste caso, a uma ética de conduta (FRANÇA FILHO, 2008). O autor também destaca que a gestão privada possui um "aparato técnico-metodológico extremamente privilegiado, pois são aproximadamente cem anos de conhecimento formal produzido no âmbito da disciplina administrativa que esteve sempre predominantemente voltada para o campo da empresa" (FRANÇA FILHO, 2008). A gestão pública aproxima-se da gestão estratégica no que diz respeito a sua operacionalização, pois ambas baseiam-se em uma lógica de poder que se orienta pela racionalidade instrumental e técnica, podendo ser exercida segundo estilos mais democráticos, técnico-burocráticos ou clientelistas, dependendo da política vigente (FRANÇA FILHO, 2008). No entanto, ela difere da gestão estratégica pela natureza de seus objetivos, que não se restringem a questões econômicas simplesmente. 
De acordo com França Filho (2008), embora o conceito de Gestão Social esteja em construção, ele destaca que há fatores comuns na ação de diversos grupos, como, por exemplo, a preocupação com uma conduta ética, a valorização da transparência e a democratização das relações e decisões. Para finalizar, o autor coloca dois desafios para a Gestão Social: um deles é criar parcerias efetivas entre sociedade civil e Estado, superando a cultura política tradicional; o outro é construir um embasamento metodológico que viabilize uma gestão legitimamente comprometida com o social, aproveitando o "aparato de conhecimento técnico-gerencial desenvolvido pela ciência administrativa de orientação estritamente gerencialista e corporativa" (FRANÇA FILHO, 2008), porém respeitando a “especificidade, em termos de racionalidade, do universo da Gestão Social” (FRANÇA FILHO, 2008).

Outros autores que exploraram o tema da Gestão Social foram Pereira e Rigatto (2011), que, em sua obra, utilizam o termo Gestão Social de políticas públicas, definindo-o da seguinte maneira

processo gerencial dialógico em que a concepção, a elaboração, a implementação e avaliação de políticas é compartilhada entre os participantes da ação no âmbito da esfera pública, onde todos têm o direito à fala sem nenhum tipo de coação e tomam as decisões de forma democrática e deliberativa (PEREIRA E RIGATTO, 2011).

Essa definição utilizada por Pereira e Rigatto (2011) tem embasamento no conceito utilizado por Tenório (1998), conforme já apresentado anteriormente, o qual tem como principais elementos a contraposição da Gestão Social à gestão estratégica e a valorização de um processo mais participativo e dialógico, que, por sua vez, está alinhado ao pensamento de Habermas. Pereira e Rigatto (2011) também destacam a importância de se definir "política" ou "política pública" para se construir a definição do termo Gestão Social de políticas públicas. Para isso, retomam a obra de Heidemann e Salm (2009), que diz que "a política é concebida, finalmente, como a teoria política ou o conhecimento dos fenômenos ligados à regulamentação e ao controle da vida humana em sociedade, como também à organização, ao ordenamento e à administração das jurisdições político-administrativas" (HEIDEMANN; SALM, 2009). Dessa forma, Pereira e Rigatto (2011) dizem que "as políticas públicas constituem um meio de o Estado governar a sociedade e o mercado, historicamente observado". 
Pereira e Rigatto (2011) abordam o tema da Gestão Social a partir de reflexões sobre a relação entre Estado e sociedade e traçam uma linha do tempo, destacando as mudanças ocorridas que pudessem possibilitar o desenvolvimento da Gestão Social de políticas públicas. Ele inicia a análise destacando que historicamente o Estado exerceu uma função coercitiva e a sua relação com a sociedade era feita por meio de negociações ou de cessão por parte da população. Nesse processo, o Estado foi forçado a reconhecer direitos individuais e coletivos, além das obrigações dos cidadãos com o Estado (Pereira e Rigatto, 2011). Contudo, quando o Estado esteve em crise, optou-se por eliminar os intermediários e implantar um governo direto, ou seja, a coerção era exercida diretamente entre Estado e sociedade. Segundo Tilly (1996 apud Pereira e Rigatto, 2011), esse modelo de Estado se espalhou pela Europa. Seguindo a análise, também vale destacar que a ascensão da burguesia também trouxe impactos nessa relação, pois esta passou a reivindicar maior proteção, justiça, produção e distribuição (Pereira e Rigatto, 2011). Ainda em relação à ascensão da classe burguesa, Pereira e Rigatto (2011) retomam o conceito de esfera pública, utilizado por Habermas (2003 apud Pereira e Rigatto, 2011), que se refere à burguesia como classe constituinte da esfera pública. Nesse contexto, Pereira e Rigatto (2011) pontuam que as políticas públicas eram direcionadas para atender demandas da classe burguesa, marginalizando as demais parcelas constituintes da sociedade. De acordo com Pereira e Rigatto (2011), considerando as ideias de Habermas (2003 apud Pereira e Rigatto, 2011), pode-se dizer que a burguesia "promoveu a primeira ruptura de poder com a monarquia, abrindo espaço para o estabelecimento dos direitos sociais, políticos e civis modernos, expressos por meio de políticas públicas correlacionadas" (PEREIRA E RIGATTO, 2011). Pereira e Rigatto (2011) concluem dizendo que

\footnotetext{
historicamente, é possível promover uma segunda ruptura de poder no sentido de incluir amplamente as classes sociais que foram excluídas até hoje por meio da Gestão Social das políticas públicas. Isso será cada vez mais possível à medida que a sociedade assuma responsabilidades de gerenciar os negócios públicos. (PEREIRA E RIGATTO, 2011)
}

Pereira e Rigatto (2011) também retomam o conceito de Estado Modesto ou Estado Moderno, de Crozier (1989 apud Pereira e Rigatto, 2011), o qual considera que "o Estado é essencial para iniciar uma mudança no sentido de deixar de ser 'sagrado' para ser 'modesto', cujo significado o levaria a estar a serviço da sociedade, de compreender os cidadãos, de 
ajudá-los a realizarem seus próprios objetivos" (PEREIRA E RIGATTO, 2011). Crozier (1989 apud Pereira e Rigatto, 2011) acreditava que o Estado deveria se democratizar e se modernizar para, então, promover a modernização da sociedade.

Contudo, Pereira e Rigatto (2011) trazem o contraponto feito por Santos (2006 apud Pereira e Rigatto, 2011), que argumenta que "deve-se cada vez mais democratizar a sociedade e, em um movimento dialético, democratizar o próprio Estado". Portanto, Santos (2006 apud Pereira e Rigatto, 2011) propõe um movimento inverso do proposto por Crozier (1989 apud Pereira e Rigatto, 2011). Santos (2006 apud Pereira e Rigatto, 2011) também traz à tona a questão de que o contrato social suscita uma "tensão dialética entre regulação social e a emancipação social, entre a vontade geral e as vontades particulares" (PEREIRA E RIGATTO, 2011). Santos (2006 apud Pereira e Rigatto, 2011) coloca que o contrato social moderno possui critérios de inclusão e exclusão, mas que até o momento havia sido possível solucionar os conflitos proporcionando maior inclusão do que exclusão. Contudo, essa lógica vem se invertendo ultimamente e "percebe-se uma quantidade cada vez maior de indivíduos marginalizados e uma sociedade repleta de "fascismo social"' (PEREIRA E RIGATTO, 2011). Para Santos (2006 apud Pereira e Rigatto, 2011), as tensões geradas pelo contrato social não podem ser resolvidas com a questão contratual apenas, pois há três elementos que interferem na sua gestão, a saber: "um 'regime geral de valores', um 'sistema comum de medidas' e um 'espaço-tempo privilegiado'” (PEREIRA E RIGATTO, 2011). Nesse cenário, o Estado passa a exercer um papel mínimo e "perde sua capacidade de alterar as condições contratuais e de promover o bem comum" (PEREIRA E RIGATTO, 2011). Santos (2006 apud Pereira e Rigatto, 2011) aponta como possível solução para essa questão a democratização do trabalho e o reconhecimento do "novo papel do Estado em um novo contrato social, o de articulador e coordenador do conjunto de ações sociais, priorizar a democracia participativa, gerar igualdade de oportunidades, coordenando interesses contraditórios e divergentes na busca de critérios de redistribuição" (PEREIRA E RIGATTO, 2011). Santos (2006 apud Pereira e Rigatto, 2011) também destaca que o terceiro setor pode ser um espaço da sociedade que contribua para a democratização do Estado. Em relação a esse assunto, Pereira e Rigatto (2011) também retomam uma análise de Marilena Chauí, que acredita que as mudanças na relação entre Estado e sociedade são possíveis e que estão no âmbito dos movimentos sociais, que, por sua vez, abarcam o terceiro setor. Segundo Pereira e Rigatto (2011), 
a organização desses grupos [movimentos sociais], a mediação pacífica de interesses, as representatividades articuladas de forma a dialogar e instalar um processo social dialético é o objetivo da Gestão Social.

Para finalizar, Pereira e Rigatto (2011) retomam a ideia de ruptura trazida por Habermas e apontam que ess ruptura deve "ocorrer a partir das classes populares com o Estado e a burguesia que dele se apropria" (PEREIRA E RIGATTO, 2011). Segundo Pereira e Rigatto (2011), há condições regulatórias para que isso seja feito, pois a Constituição Federal já garante os direitos sociais, políticos e civis. No entanto, as políticas públicas que implementarão esses direitos devem considerar a inclusão e a emancipação dos cidadãos, "pois não é possível dar autonomia a alguém que não está inserido num contexto de cidadania ou sem acesso aos direitos sociais, políticos e civis” (PEREIRA E RIGATTO, 2011).

Expusemos acima algumas das perspectivas em que a Gestão Social vem sendo estudada no Brasil. Nesse contexto de diversidade de pesquisas sobre o tema, Cançado (2011) propôs uma primeira aproximação da delimitação do campo de Gestão Social como sendo

\footnotetext{
a tomada de decisão coletiva, sem coerção, baseada na inteligibilidade da linguagem, na dialogicidade e entendimento esclarecido como processo, na transparência como pressuposto e na emancipação enquanto fim último (CANÇADO, 2011).
}

Esse conceito foi trabalhado no contexto de sua tese de doutorado, na qual Cançado tinha o objetivo de "apresentar uma primeira aproximação de construção dos fundamentos teórico-metodológicos da Gestão Social e de uma primeira delimitação dessa área enquanto campo do conhecimento científico" (CANÇADO, 2011). Para isso, buscou mapear e analisar a produção científica de Gestão Social e identificar e analisar as correntes de pensamento em Gestão Social.

Em suas análises, Cançado (2011) identificou algumas características básicas da Gestão Social, sendo elas: a tomada de decisão coletiva e sem coerção, a dialogicidade, a transparência e a emancipação. Em sua tese, Cançado (2011) também apontou que "a Gestão Social constitui-se um campo de conhecimento científico com fundamentos teórico- 
metodológicos específicos" (CANÇADO, 2011), de acordo com critérios de demarcação e delimitação conceitual utilizados pelo autor.

Araújo (2012) também tratou do tema em sua tese de doutorado, em que buscou conhecer os elementos que atribuem consistência/inconsistência no conceito de Gestão Social pelo seu exame nos processos de formação de gestores sociais. Araújo (2012) aponta que há inconsistências nas diversas concepções de Gestão Social manifestadas nos processos de formação, influenciando discursos e práticas dos gestores sociais. O autor ainda diz que há uma imprecisão conceitual que possibilita a ocorrência de ambiguidades (pode ter mais de um sentido ou significado) e ambivalências (tem dois aspectos ou sentidos opostos).

Em outro trabalho, Araújo (2014) propõe uma síntese conceitual em que afirma que a Gestão Social é

um campo de saberes e práticas referentes aos modos de gerir interorganizações, territórios e relações sociais, sendo orientado por uma ideologia social e do interesse público, orquestrando diferentes escalas e tipos de poder. Prevalecem a lógica humanitária, do interesse público e do social em detrimento dos interesses privados, individuais e monetários. Os saberes produzidos no campo da Gestão Social nascem de processos indutivos de práticas gestionárias participativas, horizontais, dialógicas e democráticas que podem ser desenvolvidas em diferentes tipos de organização. A fronteira para suas aplicações é definida pelo caráter de expansão da esfera pública e da coprodução do bem público

Mendonça, Gonçalves-Dias e Junqueira (2012) fizeram uma reflexão do campo de Gestão Social a partir da análise do VI Encontro Nacional da Rede de Pesquisadores de Gestão Social (Enapegs), realizado em São Paulo. Segundo os autores, o termo Gestão Social, conforme vem sendo utilizado por pesquisadores da Rede de Pesquisadores de Gestão Social (RGS),

tem como objeto de estudo a gestão de problemáticas sociais e ambientais que necessitam de uma visão intersetorial e interorganizacional, considerando seu espaço de articulação em um contexto de constante fortalecimento democrático, onde múltiplos atores compartilham interesses, visões e ações dentro de um território. (MENDONÇA, GONÇALVES-DIAS E JUNQUEIRA, 2012) 
Para Mendonça, Gonçalves-Dias e Junqueira (2012) a Gestão Social se estabelece na esfera pública com objetivos não apenas econômicos, mas sociais, políticos, humanos e ambientais, ao contrário da gestão empresarial, que dominantemente tem interesses apenas privados. Para os autores, a ação social pode ser oriunda tanto da intervenção estatal, na garantia dos direitos sociais, por exemplo, como pode ser fruto da ação de organizações sem fins lucrativos, na parceria para a execução de políticas sociais (MENDONÇA, GONÇALVES-DIAS E JUNQUEIRA, 2012). O desafio é atuar buscando a transformação social em um contexto de democratização e ampliação dos atores que trabalham com a temática social, seja através de políticas públicas, iniciativas da sociedade civil ou iniciativas do mercado.

De acordo com Mendonça, Gonçalves-Dias e Junqueira (2012), até o início da década de 1990, o debate sobre Gestão Social no campo da administração restringia-se às organizações do terceiro setor (Tenório, 2009 apud Mendonça, Gonçalves-Dias e Junqueira, 2012), porém posteriormente o debate se ampliou em outras áreas como o serviço social, ciências sociais, economia e comunicação.

Segundo Mendonça, Gonçalves-Dias e Junqueira (2012), a ampliação do uso do termo Gestão Social teve duas principais consequências: uma delas foi a banalização do termo e a outra foi o estímulo para o desenvolvimento de um campo de conhecimento científico (Cançado et al., 2011 apud Mendonça, Gonçalves-Dias e Junqueira, 2012).

A seguir, apresentaremos um quadro com a síntese dos conceitos e perspectivas da Gestão Social tratados acima.

\section{Quadro 1: Principais autores e perspectivas de Gestão Social}

\begin{tabular}{|cll|}
\hline Autor & \multicolumn{1}{c|}{ Conceito } & Referência \\
\hline \multirow{4}{*}{ Tenório } & $\begin{array}{l}\text { o processo gerencial dialógico no qual a autoridade decisória é compartilhada } \\
\text { entre os participantes da ação (ação que possa ocorrer em qualquer tipo de }\end{array}$ & \\
& $\begin{array}{l}\text { sistema social - público, privado ou de organizações não-governamentais). O } \\
\text { adjetivo social qualificando o substantivo gestão será entendido como o espaço } \\
\text { privilegiado de relações sociais em que todos têm o direito à fala, sem nenhum }\end{array}$ & TENÓRIO, 2005 \\
& tipo de coação.
\end{tabular}




\begin{tabular}{|c|c|c|}
\hline Fischer & $\begin{array}{l}\text { um processo de mediação transformador que: articula múltiplas escalas de } \\
\text { poder individual e societal; trabalha a identidade de processos, refletindo e } \\
\text { criando pautas culturais; coordena interorganizações eficazes; promove ação e } \\
\text { aprendizagem coletivas; comunica-se e difunde resultados; presta contas à } \\
\text { sociedade; reavalia e recria estratégias, tendo por processo, alvo e motor, o } \\
\text { desenvolvimento, considerando dimensões tangíveis e intangíveis, objetivas e } \\
\text { subjetivas, que conformam organizações complexas e instituições. }\end{array}$ & FISCHER, 2002 \\
\hline $\begin{array}{l}\text { Boullosa e } \\
\text { Schommer }\end{array}$ & $\begin{array}{l}\text { o processo de construção da Gestão Social como alternativa de governança } \\
\text { fundamenta-se no propósito de promover avanços nas práticas de gestão para a } \\
\text { democratização nas relações sociais, por meio de práticas participativas e de } \\
\text { engajamento nas decisões e práticas, em modelos decisórios de baixo para cima } \\
\text { (bottom-up), privilegiando a dimensão dialógica e relacional da gestão } \\
\text { (TENÓRIO, 2002;2004). Ao contrapor-se a modos de gestão fundamentados } \\
\text { em hierarquia, controle e racionalização, a Gestão Social manifestaria um de } \\
\text { seus potenciais de inovação. }\end{array}$ & $\begin{array}{c}\text { BOULLOSA e } \\
\text { SCHOMMER, } 2008\end{array}$ \\
\hline França Filho & $\begin{array}{l}\text { A Gestão Social configura-se como espaço de atuação da sociedade civil, sendo } \\
\text { portanto, uma esfera pública não estatal. A Gestão Social é o modo de gestão } \\
\text { praticado por organizações que não são nem do mercado e nem do Estado, } \\
\text { porém, muitas vezes, mantêm relações de parceria com essas esferas para a } \\
\text { implantação e execução de determinados projetos. Essas organizações não } \\
\text { possuem objetivos econômicos, sendo que este configura-se apenas como um } \\
\text { meio para o atingimento da meta principal, que pode estar ligada a cultura, } \\
\text { política ou ecologia, de acordo com a natureza de atuação de cada organização. }\end{array}$ & $\begin{array}{l}\text { FRANÇA FILHO, } \\
2008\end{array}$ \\
\hline $\begin{array}{l}\text { Pereira e } \\
\text { Rigatto }\end{array}$ & $\begin{array}{l}\text { processo gerencial dialógico em que a concepção, a elaboração, a } \\
\text { implementação e avaliação de políticas é compartilhada entre os participantes } \\
\text { da ação no âmbito da esfera pública, onde todos têm o direito à fala sem } \\
\text { nenhum tipo de coação e tomam as decisões de forma democrática e } \\
\text { deliberativa }\end{array}$ & $\begin{array}{c}\text { PEREIRA E } \\
\text { RIGATTO, } 2011\end{array}$ \\
\hline Cançado & $\begin{array}{l}\text { a tomada de decisão coletiva, sem coerção, baseada na inteligibilidade da } \\
\text { linguagem, na dialogicidade e entendimento esclarecido como processo, na } \\
\text { transparência como pressuposto e na emancipação enquanto fim último }\end{array}$ & CANÇADO, 2011 \\
\hline Araújo & $\begin{array}{l}\text { um campo de saberes e práticas referentes aos modos de gerir } \\
\text { interorganizações, territórios e relações sociais, sendo orientado por uma } \\
\text { ideologia social e do interesse público, orquestrando diferentes escalas e tipos } \\
\text { de poder. Prevalecem a lógica humanitária, do interesse público e do social em } \\
\text { detrimento dos interesses privados, individuais e monetários. Os saberes } \\
\text { produzidos no campo da Gestão Social nascem de processos indutivos de } \\
\text { práticas gestionárias participativas, horizontais, dialógicas e democráticas que } \\
\text { podem ser desenvolvidas em diferentes tipos de organização. A fronteira para } \\
\text { suas aplicações é definida pelo caráter de expansão da esfera pública e da } \\
\text { coprodução do bem público }\end{array}$ & ARAÚJO, 2014 \\
\hline
\end{tabular}


Mendonça,

Gonçalves-

Dias e

Junqueira tem como objeto de estudo a gestão de problemáticas sociais e ambientais que necessitam de uma visão intersetorial e interorganizacional, considerando seu espaço de articulação em um contexto de constante fortalecimento democrático, onde múltiplos atores compartilham interesses, visões e ações dentro de um território.
MENDONÇA, GONÇALVES-DIAS e JUNQUEIRA, 2012

Fonte: elaborado pela autora

Além disso, a Gestão Social guarda referência com outras escolas e conceitos anteriores que, embora não utilizassem o termo Gestão Social em si, partiram das mesmas premissas. Ainda que o debate sobre a Gestão Social tenha se intensificado, a partir da década de 1990, no Brasil, podemos identificar alguns movimentos e autores, anteriores a esse período, que vinham tratando de temáticas semelhantes às da Gestão Social. Muitos desses autores são utilizados como referencial pelos pesquisadores brasileiros que tem como objeto de estudo a Gestão Social, conforme podemos ver no Box 1.

\section{Box 1: Apontamentos históricos acerca da Gestão Social}

Tenório (1998) coloca como referencial conceitual de seu artigo a perspectiva teórico-crítica da escola de Frankfurt. Um fator de destaque é que a teoria crítica tem como objeto de estudo a sociedade, e segundo Tenório (1998), "na dialética da teoria crítica, a totalidade (a sociedade) tem primazia sobre o particular, isto é, a sociedade precede o sujeito, mostrando a diferença entre o geral e o particular e a determinação deste pelo geral". Tenório (1998) ainda aponta outra diferença entre a teoria crítica e a teoria tradicional que consiste no posicionamento do pesquisador em relação ao seu objeto de estudo. Na teoria crítica o pesquisador é parte do objeto estudado. Segundo Tenório (1998) “a teoria crítica não aceita o conhecimento como distinto e superior à ação e reconhece que a pesquisa é impossível de ser desinteressada em uma sociedade em que os homens não são autônomos".

Outro movimento que pode ser identificado como um apontamento pré-histórico da Gestão Social é a Nova Administração Pública (NAP) que surgiu na década de 1960 e seus proponentes buscavam apontar falhas nas teorias até então existentes, mas sem conseguir apontar alternativas concretas para a superação de tais problemas. Embora não houvesse muita coerência intelectual entre os pesquisadores do movimento, pode-se dizer que havia três temas transversais que perpassavam as discussões, eram eles: relevância, equidade e participação. A nova administração pública superou a dicotomia de política e administração, tema recorrente nas teorias de administração pública, pois os estudos apontavam que os administradores deviam fazer parte da política. Isso porque as esferas do executivo e do legislativo não vinham dando respostas satisfatórias a determinados problemas, como por exemplo, pobreza e racismo (DENHARDT, 2012).

Denhardt (2012) também aborda a questão do Novo Serviço Público (NPS) em sua obra. Segundo o Michel Sandel (1979 apud Denhardt, 2012), havia duas tradições na vida política norte-americana: uma 
perspectiva baseada na filosofia do autointeresse, em que o governo existe apenas para mediar os interesses pessoais e coletivos específicos dos membros da sociedade e que dá sustentação a teoria da public choice e da nova gestão pública (DENHARDT, 2012). A outra perspectiva aposta na atuação do cidadão orientada pelo interesse público, em detrimento do interesse puramente pessoal. Esta perspectiva reforça o novo serviço público (DENHARDT, 2012). De acordo com Denhardt (2012), houve um ressurgimento do interesse pela ideia de comunidade nos Estados Unidos e da relação da comunidade com o governo. Outro tema que passou a se destacar foi o debate em torno do termo "sociedade civil". Segundo Denhardt (2012), "em algum lugar entre os cidadãos e seu governo deve haver um conjunto saudável e ativo de 'instituições mediadoras', que sirvam ao mesmo tempo para dar foco aos anseios e interesses dos cidadãos e para proporcionar experiências que preparem melhor esses cidadãos para a sua ação no sistema político mais amplo". Denhardt e Denhardt (2007) apud Denhardt (2012) apontam o novo serviço público como alternativa à velha administração pública e a nova gestão pública. De acordo com os autores há dois temas que balisam o novo serviço público: "(1) promover a dignidade e o valor do novo serviço público, e (2) reafirmar os valores da democracia, da cidadania e do interesse público enquanto valores proeminentes da administração pública" (DENHARDT e DENHARDT, 2007 apud DENHARDT, 2012).

Dessa forma, podemos notar que as influências da Gestão Social são oriundas desde um objeto amplo que é a teoria crítica, passando por uma escola da administração pública do século $\mathrm{XX}$, neste caso a nova administração pública (NAP), chegando até um modelo analítico, ilustrado pelo novo serviço público.

Fonte: elaborado pela autora

O objetivo desta seção não é esgotar a discussão sobre o tema, mas realizar um primeiro mapeamento das perspectivas de Gestão Social e sinalizar a polissemia do termo.

\subsection{Trajetória da pesquisa em Gestão Social}

O desenvolvimento da área de Gestão Social no Brasil pode ser compreendido a partir de três momentos que Coelho (2015) denominou de gerações. Essa proposta de análise foi feita por Coelho (2015) no prefácio do livro Gestão Social: epistemologia de um paradigma, de Airton Cardoso Cançado, José Roberto Pereira e Fernando Guilherme Tenório. O intuito desta seção é seguir a linha proposta por Coelho (2015), mas de maneira detalhada.

A primeira geração refere-se ao período de 1998 a 2004, em que alguns pesquisadores buscavam definir de maneira exploratória o conceito de Gestão Social. A segunda geração (2005 a 2012) é marcada pela institucionalização do Encontro Nacional de Pesquisadores em Gestão Social (ENAPEGS) e pela expansão do número de pesquisas na área. Por fim, a 
terceira geração é caracterizada pela publicação de trabalhos mais recentes que visam sedimentar o conceito de Gestão Social.

\section{Primeira Geração: de 1998 a 2004}

A primeira geração é marcada pela publicação de artigos que buscavam explorar o conceito da Gestão Social, mas a partir de referenciais teóricos e perspectivas distintas. Nesse rol de autores da primeira geração, podemos destacar Fernando Tenório, que desde 1990 estava à frente do Programa de Estudos em Gestão Social (PEGS), da Escola Brasileira de Administração Pública e de Empresas (EBAPE) da Fundação Getúlio Vargas (FGV). Embora o PEGS tivesse sido criado em 1990, destacaremos a publicação do artigo "Gestão Social: uma perspectiva conceitual" na Revista Brasileira de Administração Pública, em 1998. Nesse artigo, Tenório busca compreender o conceito de Gestão Social retomando a teoria crítica e alguns conceitos de Habermas.

Ainda nos anos 1990, Ladislau Dowbor publica um livro denominado "O que é poder local", onde traz ideias de criação de municípios capazes de realizarem uma autotransformação econômica e social. Dowbor destaca a importância da participação dos cidadãos e da proximidade destes com os processos de desenvolvimento econômico e social da comunidade. Posteriormente, em 1999, Dowbor publica o capítulo "A Gestão Social em busca de paradigmas", no livro "Gestão Social - uma questão de debate", organizado por Elizabeth de Melo Rico e Raquel Raichelis. Nesse texto, Dowbor pontua que não há paradigmas de gestão adequados para áreas sociais, como saúde e educação, por exemplo; e complementa destacando que a estrutura estatal não é capaz de ser flexível e horizontal, modo segundo o qual essas demandas sociais poderiam ser melhores atendidas.

Em 1999, Genauto Carvalho de França Filho publica o artigo "Economia solidária e dádiva", na Revista Organizações \& Sociedade, onde ele aborda a questão da economia solidária, a partir da realidade francesa. No texto, ele destaca a necessidade de se propor formas de entendimento de determinados fenômenos organizacionais que não podem ser compreendidos sob a perspectiva das teorias vigentes à época. A partir de 2001, Genauto França Filho passou a integrar o Núcleo de Estudos sobre Poder e Organizações Locais (NEPOL) e desenvolver pesquisas nas linhas de economia solidária, Gestão Social e terceiro setor. 
Rosinha Machado Carrion, em 1999, torna-se coordenadora do Núcleo Interdisciplinar de Estudos e Pesquisa sobre o Terceiro Setor/NIPETS, da Universidade Federal do Rio Grande do Sul (UFRGS). No ano de 2000, Carrion publica o artigo "Organizações privadas sem fins lucrativos: a participação do mercado no terceiro setor", em que trata a questão da delimitação do terceiro setor, o debate conceitual acerca das organizações da sociedade civil e o desenvolvimento do terceiro setor no contexto brasileiro. Em textos posteriores, Carrion também aborda outros temas do universo da Gestão Social, como: economia solidária, empreendedorismo social, participação, microcrédito etc.

Outro autor de destaque desta primeira geração é Luciano Prates Junqueira, que, em 2000, escreveu a apresentação do número especial sobre "Intersetorialidade e Redes Sociais" da Revista de Administração Pública, além de publicar um artigo denominado "Intersetorialidade, transetorialidade e redes sociais na saúde" na mesma edição. Nesses textos, Junqueira traz ideias importantes como a necessidade de se ter uma visão integrada dos problemas sociais e a incorporação dos conceitos de integração, território e equidade. Podemos apontar ainda a proposição de uma ação intersetorial capaz de articular Estado, organizações privadas e organizações públicas, visando à solução de problemas sociais. Luciano Junqueira é o atual coordenador do Núcleo de Estudos Avançados do Terceiro Setor (NEATS), grupo ao qual está vinculado desde 2001.

Dessa geração também podemos destacar a publicação do livro "Gestão do desenvolvimento e poderes locais: marcos teóricos e avaliação", em 2002, que teve como organizadora Tânia Fischer. Nele, a autora escreve um artigo intitulado "Poderes locais, desenvolvimento e gestão: introdução a uma agenda", no qual aborda os conceitos de gestão do desenvolvimento social e poderes locais. Desde essa época, Tânia Fischer estava vinculada ao Núcleo de Estudos Sobre Poder e Organizações Locais (NEPOL), da Escola de Administração da Universidade Federal da Bahia, e atualmente é coordenadora do Centro Interdisciplinar em Desenvolvimento e Gestão Social (CIAGS).

Em 2005, Rosa Maria Fischer publicou o artigo "Estado, Mercado e Terceiro Setor: uma análise conceitual das parcerias intersetoriais" a partir de pesquisas anteriormente realizadas pelo Centro de Empreendedorismo Social e Administração em Terceiro Setor (CEATS). No texto, Rosa Maria Fischer faz uma análise histórica da evolução no padrão de colaboração intersetorial no Brasil e aponta que essas alianças intersetoriais podem se tornar modelos de gestão efetivos para a prática de atuação social. Fischer também trata do conceito 
de "responsabilidade social" e pontua que este está associado ao fortalecimento da participação da sociedade civil organizada.

Esses autores da primeira geração estavam discutindo temáticas e apontando preocupações que hoje se constituem os pilares e princípios da Gestão Social. Posteriormente, esses objetos de estudos - Gestão Social, poder local, participação, economia solidária, intersetorialidade, desenvolvimento social, responsabilidade social - passaram a ser discutidos sob o conceito guarda-chuva da Gestão Social, inaugurando a segunda geração.

Segunda Geração: 2005 a 2011

Em 2005 foi criada a divisão acadêmica de Administração Pública e Gestão Social no Encontro da Associação Nacional de Pós-Graduação e Pesquisa em Administração (EnANPAD). Devemos destacar, ainda, a criação de uma divisão anterior, em 2003, denominada "Gestão Social e Ambiental", também na EnANPAD, e a realização do Encontro de Administração Pública e Governança da Associação Nacional de Pós-Graduação e Pesquisa em Administração (EnAPG) em 2004, o qual foi iniciativa da divisão acadêmica de Administração Pública e Gestão Social da ANPAD. Data desse período também a ampliação do número de disciplinas relacionadas à Gestão Social em cursos de graduação e pósgraduação. A realização de eventos que acolhiam trabalhos acadêmicos na área da Gestão Social associada à ampliação do ensino na área, impulsionou a criação da Rede de Pesquisadores de Gestão Social (RGS).

A partir da estruturação da Rede de Pesquisadores de Gestão Social (RGS) foi criado o Encontro Nacional da Rede de Pesquisadores de Gestão Social (ENAPEGS) por iniciativa de diversos pesquisadores advindos do Centro Interdisciplinar de Desenvolvimento e Gestão Social da Universidade Federal da Bahia (CIAGS/UFBA) (MENDONÇA, GONÇALVESDIAS e JUNQUEIRA, 2012).

Podemos analisar o desenvolvimento do campo da Gestão Social, nesse período, a partir dos temas e eixos temáticos do Encontro Nacional da Rede de Pesquisadores de Gestão Social (ENAPEGS). Em 2007, o tema foi “Gestão Social: Práticas em Debate e Teorias em Construção", e os artigos apresentados buscavam conceituar a Gestão Social e discutir algumas experiências, ou seja, o primeiro encontro tinha um caráter exploratório. Na segunda edição, em 2008, o tema foi “Os Desafios da Formação em Gestão Social”, e o intuito dessa edição era promover a interação entre pesquisadores e instituições, visando o 
desenvolvimento da área de Gestão Social. Posteriormente, as edições de 2009, 2010, 2011 e 2012 buscaram promover a interação entre os objetos de estudo da Gestão Social e Administração/Gestão/Políticas Públicas, visando a identificação de aproximações ou divergências teórico-conceituais. Os temas foram "Gestão Social e Políticas Públicas de Desenvolvimento: Ações, Articulações e Agenda", "Gestão Social e Gestão Pública: Interfaces e Delimitações", "Gestão Social como Caminho para a Redefinição da Esfera Pública" e "Gestão Social: Mobilizações e Conexões", respectivamente. Durante o período da segunda geração, notamos a institucionalização da Gestão Social como arcabouço analítico e um campo acadêmico da gestão pública brasileira.

Em relação aos eixos temáticos notamos que em 2007 havia poucos eixos, os quais buscavam definições do conceito e compartilhamento das práticas de Gestão Social. A partir de 2008 houve uma ampliação dos eixos temáticos, incorporando assuntos como: economia solidária e cooperativismo, empreendedorismo social, responsabilidade socioambiental, redes sociais e desenvolvimento territorial e epistemologia e metodologias. Nos anos seguintes, 2009 e 2010, acrescentam-se os eixos de "Gestão Social e políticas públicas”, "diversidade, movimentos sociais e ações afirmativas", "ensino e pesquisa em Gestão Social" e "inovação e tecnologias sociais". Esse movimento de ampliação de eixos temáticos permitiu que trabalhos acadêmicos com concepções diferentes de Gestão Social fossem acolhidos no ENAPEGS, gerando o fenômeno da polissemia do conceito. Exceto em 2011, onde houve uma reformulação quase completa dos eixos ${ }^{1}$, a partir de 2012 notamos uma redução no número de eixos temáticos e a tendência de se buscar uma conceituação da Gestão Social e a definição do que se encaixa e não se encaixa dentro do conceito.

\section{Terceira Geração: pós 2012}

A terceira geração, em curso, inicia-se com essa tendência de depuração do conceito de Gestão Social e é marcada pela publicação de pesquisas que buscam sedimentar o conceito, além de problematizar algumas questões. Neste período devemos destacar a tese de doutorado de Airton Cardoso Cançado, defendida em 2011, cujo título é "Fundamentos Teóricos da

\footnotetext{
${ }^{1}$ Eixos temáticos do V ENAPEGS (2011): "Democracias" nos processos de construção de "Outras Economias": Trilhas para a Redefinição da Esfera Pública; Construção da teoria do conhecimento em Gestão Social; Coprodução e Inovação Social na Esfera Pública; Ensino, pesquisa e extensão em Gestão Social; Filosofia da diferença, biopolítica, produção de subjetividade; Gestão Social, Arte e Cultura: valores e tecnologias para a gestão do patrimônio das cidades; Gestão Social, Redes e Movimentos Sociais; O papel das Metodologias Integrativas na ampliação da esfera pública.
} 
Gestão Social" e possui como objetivo a apresentação de uma delimitação preliminar do campo científico da Gestão Social e a elaboração de um esboço de seus fundamentos teóricos. Essa pesquisa foi muito importante para o campo da Gestão Social, pois retomou as concepções de Gestão Social e analisou as publicações na área com o intuito de identificar os diferentes significados que o conceito assumia. A partir da análise da produção científica, Cançado propõe certas categorias teóricas para a Gestão Social.

Outra obra de destaque deste período é a tese de Edigilson Tavares de Araújo, defendida em 2012, intitulada "(In)Consistências da Gestão Social e seus processos de formação: um campo em construção", que tem como objetivo identificar os elementos que atribuíam consistência/inconsistência ao conceito de Gestão Social e como se apresentam no processo de formação dos gestores sociais.

Vale destacar que há outros trabalhos que buscam o refinamento do conceito de Gestão Social e que entre esses trabalhos, algumas vezes, existem controvérsias. Cançado (2013) ressalta alguns pontos a serem debatidos entre Cançado (2011) e Araújo (2012), por exemplo. Segundo Cançado (2013), Araújo (2012) propõe que o campo da Gestão Social está em construção e apresenta inconsistências. Já Cançado (2011) afirma que a Gestão Social já possui alguma forma, sendo possível fazer algum tipo de classificação. Cançado (2011) coloca que, embora a Gestão Social ainda não atenda aos critérios de demarcação de um paradigma, este passo não está tão distante de acontecer. Outro ponto divergente entre os autores é que Cançado (2011) diz que a Gestão Social atende a cinco dos sete critérios para a demarcação ${ }^{2}$ do conhecimento científico e, portanto, possui um bom potencial para ser reconhecida como campo do conhecimento científico ${ }^{3}$. Entretanto, Araújo (2012) afirma que é precoce considerar que a Gestão Social é um campo científico disciplinar consolidado. Podemos ainda citar a questão sobre a institucionalização da Gestão Social, em que Araújo

\footnotetext{
${ }^{2}$ Cançado (2011) elenca os seguintes critérios de demarcação atendidos: falseabilidade (Popper, 2007 apud Cançado, 2011), não há um critério de demarcação,vale tudo (Feyerabend, 2007 apud Cançado, 2011), não existe um conceito único de ciência (Chalmers, 1993; 1994 apud Cançado, 2011), 1ª ruptura epistemológica (Santos, 2003 apud Cançado, 2011) e discutibilidade (Demo, 2007 apud Cançado, 2011).

${ }^{3}$ Bourdieu (1983) aponta que o campo científico é um espaço de disputa do monopólio da competência científica. Nas palavras do autor "O campo científico, enquanto sistema de relações objetivas entre posições adquiridas (em lutas anteriores),é o lugar, o espaço de jogo de uma luta concorrencial. O que está em jogo especificamente nessa luta é o monopólio da autoridade científica definida, de maneira inseparável, como capacidade técnica e poder social; ou, se quisermos, o monopólio da competência científica, compreendida enquanto capacidade de falar e de agir legitimamente (isto é, de maneira autorizada e com autoridade), que é socialmente outorgada a um agente determinado" (BOURDIEU, 1983). Boullosa e Schommer (2009), conforme já discutimos acima, destacam que há um movimento no campo que está buscando a definição e sintetização do conceito. Neste contexto, podemos identificar que há uma disputa, no âmbito da construção do campo da Gestão Social, pelo monopólio da competência científica, que, de acordo com Bourdieu (1983), é a capacidade de falar e agir legitimamente.
} 
(2012) busca analisar com cuidado, alegando o risco da perda do caráter inovador do termo. Cançado (2011) argumenta que a institucionalização pode coibir a banalização do termo e fomentar o avanço do campo.

Assim como qualquer campo de conhecimento recente e em busca de consolidação no país, o campo da Gestão Social sofre críticas. Podemos destacar alguns pontos que são questionados, como por exemplo: a adequação de sua nomenclatura, a polissemia do termo, a institucionalização ou não do campo de conhecimento e a ausência de uma modelização do conceito. Para maiores detalhes, ver Box 2.

\section{Box 2: Algumas críticas à abordagem da Gestão Social}

Na terceira edição do Encontro Nacional de Pesquisadores em Gestão Social (ENAPEGS) ocorrida em 2009, Pinho (2009) publicou o artigo “Gestão Social: conceituando e discutindo os limites e possibilidades reais na sociedade brasileira" em que destaca alguns pontos que necessitam ser refletidos acerca do desenvolvimento da área da Gestão Social no Brasil. O primeiro deles refere-se à nomenclatura utilizada, que segundo Pinho (2009), "a expressão Gestão Social seria muito pequena para promover as mudanças que o conceito sugere". Para Pinho (2009), uma alternativa interessante seria a utilização da expressão "gestão emancipadora". Outra crítica apresentada pelo autor diz respeito às suas possibilidades de promoção de mudanças, conforme palavras do autor, "a promessa emancipatória que o conceito implicitamente carrega (mas não o nome) parece difícil de ser cumprida a partir do nível local e gestionário" (PINHO, 2009). E por fim, Pinho (2009) questiona a viabilidade da implantação de um modelo de gestão pública que promova a participação popular, devido às “condições estruturais da formação social brasileira onde não se identifica uma sociedade civil vigorosa e ativa, tanto pelo peso da trajetória histórica da nossa formação onde o Estado tem um papel decisivo quanto por características dessa própria sociedade civil” (PINHO, 2009). Em um texto posterior, Pinho e Santos (2013), também apontam a questão da polissemia do termo Gestão Social, levantando a preocupação do termo se perder em meio a uma diversidade de objetos de estudo e de áreas consolidadas, como a própria administração pública tradicional.

Na tentativa de estabelecer um contraponto às críticas de Pinho (2009), Cançado, Tenório e Pereira (2011) apontam que o termo gestão social está em conformidade com seu significado no dicionário, pois traz a ideia de uma gestão coletiva e realizada pela e para a sociedade. Já em relação a viabilidade da implantação de um modelo de gestão pública que promova a participação popular , Cançado, Tenório e Pereira (2011) colocam que a construção da participação deve ocorrer durante o processo e não após a transformação da sociedade civil brasileira, como afirma Pinho (2009).

Boullosa e Schommer (2008) apontam que o esforço de institucionalização do campo e de modelização pode comprometer o caráter inovador e experimental que era propiciado pela instabilidade de um processo de aprendizagem ainda em curso. Isso porque a partir do momento que define-se um conceito ou um modelo, tudo 
aquilo que não se encaixa no que foi proposto, fica automaticamente excluído. Para as autoras, a diversidade de experiências e objetos é o que caracteriza e enriquece o campo da Gestão Social.

Em 2005, Paes de Paula (2005) publicou o artigo “Administração Pública Brasileira entre o Gerencialismo e a Gestão Social" onde analisou e comparou a administração gerencial e a administração societal, a partir de seis variáveis: a origem, o projeto político, as dimensões estruturais enfatizadas na gestão, a organização administrativa do aparelho do Estado, a abertura das instituições à participação social e a abordagem de gestão. Em relação a variável de dimensões estruturais do modelo de gestão, Paes de Paula (2005) aponta que há três dimensões que devem ser consideradas para a construção de uma gestão pública democrática: econômicofinanceira, que trata das questões das finanças públicas e investimentos estatais; institucional-administrativa, que se relaciona com a estrutura e articulação dos órgãos do governo; e sociopolítica que envolve questões da relação entre Estado e sociedade. Segundo Paes de Paula (2005), a administração pública gerencial concentrou suas ações nas duas primeiras dimensões, desenvolvendo propostas no campo econômico, além de uma reforma administrativa. A administração pública societal focou apenas na dimensão sociopolítica, não apresentando nenhum projeto acabado para as dimensões econômico-financeira e institucional-administrativa, o que configurou um ponto negativo para o desenvolvimento e disseminação deste modelo.

Bresser-Pereira (2005) contesta o artigo de Paes de Paula (2005), tecendo algumas críticas sobre o modelo de administração pública societal. Ele diz que a administração pública gerencial é um modo de gerir o aparelho do Estado e os serviços por ele oferecidos, portanto, não se trata de escolher um regime liberal ou participativo. Para Bresser-Pereira (2005), o conceito de administração pública societal apresentado por Paes de Paula (2005) se trata de um aspecto da democracia participativa. Paes de Paula (2005), em uma tréplica, diz que a administração pública societal é uma forma de organizar e administrar o Estado, mas que, no entanto, apesar de buscarem alternativas para a gestão pública, não havia, até aquele momento, uma proposta para a organização administrativa do Estado, assim como foi implementada pela administração pública gerencial no Brasil na década de 1990.

Fonte: Elaborado pela autora

\subsection{Organização acadêmica da Gestão Social no Brasil}

\subsubsection{Ensino e pesquisa}

Nesta seção apresentaremos um panorama do ensino e pesquisa em Gestão Social, no Brasil. Em relação aos cursos de graduação em Gestão Social, hoje há quatro cursos cadastrados no Ministério da Educação, sendo dois de bacharelado, um tecnológico e um sequencial. Embora nenhum apresente o termo "Gestão Social" em sua denominação, é possível apontar que eles tratam da temática, através da verificação da matriz curricular de cada curso. 
Quadro 2: cursos de graduação em Gestão Social

\begin{tabular}{lll}
\hline \multicolumn{1}{c}{$\begin{array}{c}\text { Instituição } \\
\text { (IES) }\end{array}$} & \multicolumn{1}{c}{ Nome do Curso } & \multicolumn{1}{c}{ Grau } \\
\hline UFRGS & ADMINISTRAÇÃO PÚBLICA E SOCIAL & Bacharelado \\
\hline UFBA & GESTÃO PÚBLICA ${ }^{4}$ & Tecnológico \\
UFCA & ADMINISTRAÇÃO PÚBLICA & Bacharelado \\
UNISINOS & GESTÃO DO SOCIAL & Sequencial \\
\hline
\end{tabular}

Fonte: Ministério da Educação - Sistema e-MEC/2015

Em relação à pós-graduação lato-sensu, encontramos 20 cursos que tratam da Gestão Social, sendo que a maioria está concentrada na área de ciências sociais, negócios e direito. Durante o levantamento de dados não foi encontrado nenhum curso de pós-graduação strictosensu com o termo "Gestão Social” em sua denominação.

\section{Quadro 3: cursos de pós-graduação lato-sensu em Gestão Social}

\begin{tabular}{|c|c|c|c|c|c|}
\hline $\begin{array}{l}\text { Instituiçãa } \\
\text { (IES) }\end{array}$ & Denominação & Área & $\begin{array}{c}\text { Modalid } \\
\text { ade }\end{array}$ & $\begin{array}{c}\text { Carga } \\
\text { Horária }\end{array}$ & $\begin{array}{l}\text { UF de } \\
\text { Oferta }\end{array}$ \\
\hline $\begin{array}{l}\text { Centro Universitário } \\
\text { Leonardo Da Vinci - } \\
\text { UNIASSELVI }\end{array}$ & Gestão Social & $\begin{array}{l}\text { Ciências sociais, } \\
\text { negócios e direito }\end{array}$ & Presencial & 390 & $\mathrm{SC}$ \\
\hline $\begin{array}{l}\text { Escola Superior Batista } \\
\text { do Amazonas - ESBAM }\end{array}$ & $\begin{array}{l}\text { Assessoria, Consultoria } \\
\text { e Gestão Social }\end{array}$ & $\begin{array}{l}\text { Saúde e bem estar } \\
\text { social }\end{array}$ & Presencial & 400 & $\mathrm{AM}$ \\
\hline $\begin{array}{l}\text { Faculdade Antonio } \\
\text { Propicio Aguiar Franco - } \\
\text { FAPAF }\end{array}$ & $\begin{array}{l}\text { Gestão Social e } \\
\text { Politicas Públicas }\end{array}$ & $\begin{array}{l}\text { Ciências sociais, } \\
\text { negócios e direito }\end{array}$ & Presencial & 480 & $\begin{array}{l}\text { MA, } \\
\text { TO }\end{array}$ \\
\hline $\begin{array}{l}\text { Faculdade Cidade Verde } \\
\text { - FCV }\end{array}$ & Gestão Social & $\begin{array}{l}\text { Ciências sociais, } \\
\text { negócios e direito }\end{array}$ & Presencial & 420 & PR \\
\hline $\begin{array}{l}\text { Faculdade de Educação } \\
\text { Acriana Euclides da } \\
\text { Cunha - INEC }\end{array}$ & $\begin{array}{l}\text { Gestão Social e } \\
\text { Políticas públicas } \\
\text { Sociais no Brasil }\end{array}$ & Educação & Presencial & 500 & $\mathrm{AC}$ \\
\hline $\begin{array}{l}\text { Faculdade de Filosofia, } \\
\text { Ciências e Letras de Boa } \\
\text { Esperança - FAFIBE }\end{array}$ & $\begin{array}{l}\text { Políticas Públicas e } \\
\text { Gestão Social }\end{array}$ & $\begin{array}{l}\text { Ciências sociais, } \\
\text { negócios e direito }\end{array}$ & Presencial & 450 & $\begin{array}{l}\text { PB, } \\
\text { PR, } \\
\text { RN }\end{array}$ \\
\hline $\begin{array}{l}\text { Faculdade do Bico do } \\
\text { Papagaio - FABIC }\end{array}$ & $\begin{array}{l}\text { Gestão Social: Políticas } \\
\text { Sociais, Redes e Defesa } \\
\text { de Direito }\end{array}$ & $\begin{array}{l}\text { Ciências sociais, } \\
\text { negócios e direito }\end{array}$ & Presencial & 420 & TO \\
\hline Faculdade Iguaçu - FI & $\begin{array}{l}\text { Gestão Social: Politicas } \\
\text { Publicas, Redes E Def. } \\
\text { de Direitos }\end{array}$ & Educação & Presencial & 360 & PR \\
\hline
\end{tabular}

\footnotetext{
${ }^{4}$ Embora no Sistema e-MEC a denominação do curso seja "Gestão Pública", no site da Universidade Federal da Bahia (UFBA) consta a denominação "Gestão Pública e Gestão Social”
} 


\begin{tabular}{|c|c|c|c|c|c|}
\hline Faculdade Iguaçu - FI & $\begin{array}{l}\text { Gestão Social: Polít. } \\
\text { Púb., Redes e Defesa } \\
\text { de Direito-2014R }\end{array}$ & $\begin{array}{l}\text { Ciências sociais, } \\
\text { negócios e direito }\end{array}$ & Presencial & 360 & PR \\
\hline $\begin{array}{l}\text { Faculdade Integrada - } \\
\text { IAVM }\end{array}$ & $\begin{array}{l}\text { Gestão Social: Políticas } \\
\text { Sociais, Redes e Defesa } \\
\text { de Direito }\end{array}$ & $\begin{array}{l}\text { Ciências sociais, } \\
\text { negócios e direito }\end{array}$ & $\begin{array}{c}\text { A } \\
\text { Distância }\end{array}$ & 420 & RJ \\
\hline $\begin{array}{l}\text { Faculdade Metropolitana } \\
\text { do Planalto Norte - } \\
\text { FAMEPLAN }\end{array}$ & $\begin{array}{l}\text { Gestão Social e } \\
\text { Politicas Publicas }\end{array}$ & $\begin{array}{l}\text { Ciências sociais, } \\
\text { negócios e direito }\end{array}$ & Presencial & 360 & PR \\
\hline $\begin{array}{l}\text { Faculdade Nobre de } \\
\text { Feira de Santana - FAN }\end{array}$ & $\begin{array}{l}\text { Gestão Social de } \\
\text { Pessoas }\end{array}$ & $\begin{array}{l}\text { Ciências sociais, } \\
\text { negócios e direito }\end{array}$ & Presencial & 360 & $\mathrm{BA}$ \\
\hline Faculdade Rio Sono & $\begin{array}{l}\text { Gestão Social e } \\
\text { Politicas Publicas }\end{array}$ & $\begin{array}{l}\text { Ciências sociais, } \\
\text { negócios e direito }\end{array}$ & Presencial & 480 & $\begin{array}{c}\text { MA, } \\
\text { TO }\end{array}$ \\
\hline $\begin{array}{l}\text { Faculdades Integradas } \\
\text { de Patos - FIP }\end{array}$ & $\begin{array}{l}\text { Gestão Social e } \\
\text { Avaliação em Políticas } \\
\text { Públicas }\end{array}$ & $\begin{array}{l}\text { Ciências sociais, } \\
\text { negócios e direito }\end{array}$ & Presencial & 460 & $\begin{array}{l}\mathrm{PB} \\
\mathrm{PE}\end{array}$ \\
\hline $\begin{array}{l}\text { Faculdades ITECNE de } \\
\text { Cascavel - ITECNE }\end{array}$ & $\begin{array}{l}\text { Gestão Social: } \\
\text { abordagem técnico- } \\
\text { operativa }\end{array}$ & $\begin{array}{l}\text { Ciências sociais, } \\
\text { negócios e direito }\end{array}$ & Presencial & 444 & PR \\
\hline $\begin{array}{l}\text { Faculdades Unificadas } \\
\text { de Teófilo Otoni - } \\
\text { Doctum }\end{array}$ & $\begin{array}{l}\text { Gestão Social e } \\
\text { Financeira das Enti } \\
\text { Públi, Priv e Terc Setor }\end{array}$ & $\begin{array}{l}\text { Ciências sociais, } \\
\text { negócios e direito }\end{array}$ & Presencial & 360 & MG \\
\hline $\begin{array}{l}\text { Universidade do Oeste } \\
\text { de Santa Catarina - } \\
\text { UNOESC }\end{array}$ & $\begin{array}{l}\text { Gestão Social de } \\
\text { Políticas Públicas }\end{array}$ & $\begin{array}{l}\text { Saúde e bem estar } \\
\text { social }\end{array}$ & Presencial & 360 & $\mathrm{SC}$ \\
\hline $\begin{array}{l}\text { Universidade Norte do } \\
\text { Paraná - UNOPAR }\end{array}$ & $\begin{array}{l}\text { Gestão Social: Pol. } \\
\text { Públicas, Redes e } \\
\text { Defesa de Direitos }\end{array}$ & $\begin{array}{l}\text { Saúde e bem estar } \\
\text { social }\end{array}$ & $\begin{array}{c}\text { A } \\
\text { Distância }\end{array}$ & 400 & PR \\
\hline $\begin{array}{l}\text { Universidade Paranaense } \\
\text { - UNIPAR }\end{array}$ & $\begin{array}{l}\text { Gestão Social em } \\
\text { Políticas Públicas }\end{array}$ & Serviços & Presencial & 360 & PR \\
\hline $\begin{array}{l}\text { Universidade Regional } \\
\text { do Noroeste do Estado } \\
\text { do Rio Grande do Sul - } \\
\text { UNIJUI }\end{array}$ & $\begin{array}{l}\text { Administração Pública } \\
\text { e Gestão Social }\end{array}$ & $\begin{array}{l}\text { Ciências sociais, } \\
\text { negócios e direito }\end{array}$ & Presencial & 390 & RS \\
\hline
\end{tabular}

Fonte: Ministério da Educação - Sistema e-MEC/2015

No diretório dos grupos de pesquisa da Plataforma Lattes, da Coordenação de Aperfeiçoamento de Pessoal de Nível Superior (Capes), foram encontrados 24 grupos de pesquisa com o termo "Gestão Social” em sua denominação.

\section{Quadro 4: Grupos de pesquisa com o termo "Gestão Social" em sua denominação cadastrados na Plataforma Lattes em 2016}

\begin{tabular}{cccc}
\hline Instituição & Grupo & $\begin{array}{c}\text { Ano de } \\
\text { formação }\end{array}$ & Líder \\
\hline
\end{tabular}

Fundação Getúlio Vargas - Programa de Estudos em Gestão RJ
Social
1990 Fernando Guilherme Tenório 
Grupo de Estudos em Gestão

Social, Mudanças, Aprendizagem e

Competências Organizacionais

(GESMAC)

Universidade do Vale do
Rio dos Sinos

\section{Centro Universitário} Franciscano do Paraná
2002

Claudia Cristina Bitencourt

Políticas Públicas e Gestão Social

Núcleo de Pesquisa em Ética e

Gestão Social (NUPEGS)

Centro Interdisciplinar de

Desenvolvimento e Gestão Social-

CIAGS

\section{Bahia}

\section{Universidade Federal do \\ Cariri}

Laboratório Interdisciplinar de
Estudos em Gestão Social - LIEGS

Universidade do Tocantins Gestão Social - EaD
2003

Antoninho Caron

\begin{tabular}{|c|c|c|c|}
\hline $\begin{array}{l}\text { Pontifícia Universidade } \\
\text { Católica de Minas Gerais }\end{array}$ & $\begin{array}{l}\text { Núcleo de Pesquisa em Ética e } \\
\text { Gestão Social (NUPEGS) }\end{array}$ & 2003 & $\begin{array}{l}\text { Armindo dos Santos de } \\
\text { Sousa Teodósio / Roberto } \\
\text { Patrus Mundim Pena }\end{array}$ \\
\hline $\begin{array}{l}\text { Universidade Federal da } \\
\text { Bahia }\end{array}$ & $\begin{array}{l}\text { Centro Interdisciplinar de } \\
\text { Desenvolvimento e Gestão Social- } \\
\text { CIAGS }\end{array}$ & 2003 & $\begin{array}{l}\text { Tania Maria Diederichs } \\
\text { Fischer / Maria Suzana de } \\
\text { Souza Moura }\end{array}$ \\
\hline $\begin{array}{l}\text { Universidade Federal do } \\
\text { Cariri }\end{array}$ & $\begin{array}{l}\text { Laboratório Interdisciplinar de } \\
\text { Estudos em Gestão Social - LIEGS }\end{array}$ & 2006 & $\begin{array}{c}\text { Francisco Raniere Moreira } \\
\text { da Silva / Waléria Maria } \\
\text { Menezes de Morais Alencar }\end{array}$ \\
\hline Universidade do Tocantins & Gestão Social - EaD & 2007 & $\begin{array}{l}\text { Fernando Lothario da Roza / } \\
\text { Elidio Luiz Martinelli }\end{array}$ \\
\hline $\begin{array}{l}\text { Universidade Federal de } \\
\text { Lavras }\end{array}$ & $\begin{array}{l}\text { Administração Pública e Gestão } \\
\text { Social }\end{array}$ & 2007 & $\begin{array}{c}\text { Ana Alice Vilas Boas / José } \\
\text { Roberto Pereira }\end{array}$ \\
\hline $\begin{array}{l}\text { Pontifícia Universidade } \\
\text { Católica do Rio Grande do } \\
\text { Sul }\end{array}$ & $\begin{array}{l}\text { FORMASS - Grupo de Estudos } \\
\text { sobre Gestão Social e Formação } \\
\text { em Serviço Social }\end{array}$ & 2008 & Ana Lúcia Suárez Maciel \\
\hline $\begin{array}{l}\text { Universidade Federal de } \\
\text { Viçosa }\end{array}$ & $\begin{array}{l}\text { Administração Pública e Gestão } \\
\text { Social }\end{array}$ & 2008 & $\begin{array}{c}\text { Marco Aurélio Marques } \\
\text { Ferreira }\end{array}$ \\
\hline
\end{tabular}

Universidade Federal do Tocantins

Universidade Federal do Vale do São Francisco

Universidade do Estado da Bahia

Universidade Federal do
Cariri

Universidade Federal do Sul da Bahia

Universidade Federal da

Bahia

Instituto Federal de Educação Ciência e Tecnologia do Norte de Minas Gerais
Grupo de Estudos e Pesquisas em Gestão Social

Núcleo Interdisciplinar de Estudos e Tecnologias em Gestão Social NIGS

Educação Ambiental, Políticas

Públicas e Gestão Social dos

Territórios

Paidéia, Laboratório de pesquisa transdisciplinar sobre metodologias integrativas para a educação e Gestão Social

Paidéia, Laboratório de

Metodologias Integrativas para

Educação e Gestão Social

Processos de Inovação e Aprendizagem em Políticas Públicas e Gestão Social

2008

Airton Cardoso Cançado

Núcleo de Pesquisa e Extensão em Administração Pública e Gestão Social
2008 José Raimundo Cordeiro Neto / Ariádne Scalfoni Rigo

2010 Avelar Luiz Bastos Mutim / Célia Tanajura Machado $2010 \quad$ Valeria Giannella Alves

2010 Valeria Giannella Alves / Rafael Andrés Patino Orozco

2011

Rosana de Freitas Boullosa / Edgilson Tavares de Araújo

André Aristóteles da Rocha Muniz / Hélder Seixas Lima 


\begin{tabular}{|c|c|c|c|}
\hline $\begin{array}{l}\text { Universidade da } \\
\text { Amazônia }\end{array}$ & $\begin{array}{l}\text { Gestão Social e do } \\
\text { Desenvolvimento Local }\end{array}$ & 2012 & $\begin{array}{c}\text { Ana Maria de Albuquerque } \\
\text { Vasconcellos / Mário } \\
\text { Vasconcellos Sobrinho }\end{array}$ \\
\hline $\begin{array}{l}\text { Universidade Federal de } \\
\text { São Paulo }\end{array}$ & $\begin{array}{l}\text { Sistema de Informação de Gestão } \\
\text { Social: Construção de indicadores } \\
\text { sociais na área de saúde }\end{array}$ & 2012 & Ana Rojas Acosta \\
\hline $\begin{array}{l}\text { Universidade Federal do } \\
\text { Amazonas }\end{array}$ & $\begin{array}{l}\text { Grupo de Pesquisa em Gestão } \\
\text { Social, Direitos Humanos e } \\
\text { Sustentabilidade na Amazônia. }\end{array}$ & 2012 & $\begin{array}{l}\text { Marinez Gil Nogueira / } \\
\text { Lucilene Ferreira de Melo }\end{array}$ \\
\hline $\begin{array}{l}\text { Universidade Estadual } \\
\text { Paulista Júlio de Mesquita } \\
\text { Filho }\end{array}$ & $\begin{array}{l}\text { Grupo de Pesquisa em Democracia } \\
\text { e Gestão Social }\end{array}$ & 2014 & $\begin{array}{l}\text { Nelson Russo de Moraes / } \\
\text { Sergio Silva Braga Junior }\end{array}$ \\
\hline $\begin{array}{l}\text { Universidade Federal de } \\
\text { Minas Gerais }\end{array}$ & $\begin{array}{l}\text { Núcleo de estudos em Gestão } \\
\text { Social e economia solidária }\end{array}$ & 2014 & Ana Paula Gomes de Melo \\
\hline $\begin{array}{l}\text { Universidade Estadual do } \\
\text { Oeste do Paraná }\end{array}$ & $\begin{array}{l}\text { Grupo de Estudos e Pesquisa em } \\
\text { Gestão Social, Inovação, Cultura e } \\
\text { Religião }\end{array}$ & 2016 & Edson Marques Oliveira \\
\hline $\begin{array}{l}\text { Universidade Federal de } \\
\text { Santa Catarina }\end{array}$ & $\begin{array}{l}\text { Gestão Social e Administração } \\
\text { Pública }\end{array}$ & 2016 & Irineu Manoel de Souza \\
\hline
\end{tabular}

Fonte: Diretório dos Grupos de Pesquisa no Brasil - Lattes - CNPq

Ainda podemos destacar que há 43 grupos de pesquisa que possuem alguma linha de pesquisa com o termo “Gestão Social” em sua denominação. Dos 24 grupos elencados acima, no quadro 4, 12 deles também aparecem no quadro 5.

\section{Quadro 5: grupos de pesquisa com linha de pesquisa contendo o termo "Gestão Social" cadastrados na Plataforma Lattes em 2016}

\begin{tabular}{|c|c|c|c|c|}
\hline Instituição & Grupo & $\begin{array}{c}\text { Ano de } \\
\text { formação }\end{array}$ & Linha de Pesquisa & Líder \\
\hline $\begin{array}{l}\text { Universidade Federal } \\
\text { de Santa Catarina }\end{array}$ & $\begin{array}{l}\text { Grupo de Pesquisa } \\
\text { Transdisciplinar em } \\
\text { Governança da Água e do } \\
\text { Território-GTHidro }\end{array}$ & 1983 & $\begin{array}{c}\text { Estratégias para a Gestão } \\
\text { Social da Água }\end{array}$ & Daniel José da Silva \\
\hline $\begin{array}{l}\text { Universidade Federal } \\
\text { do Rio Grande do } \\
\text { Norte }\end{array}$ & $\begin{array}{l}\text { Base de Estudos e } \\
\text { Pesquisas em Estratégias e } \\
\text { Políticas de Gestão }\end{array}$ & 1995 & $\begin{array}{c}\text { Teoria das Organizações, } \\
\text { Autonomia do Social e } \\
\text { Estratégia de Gestão } \\
\text { Social }\end{array}$ & $\begin{array}{l}\text { Miguel Eduardo } \\
\text { Moreno Añez / José } \\
\text { Arimatés de Oliveira }\end{array}$ \\
\hline $\begin{array}{l}\text { Universidade Federal } \\
\text { Fluminense }\end{array}$ & $\begin{array}{l}\text { LACTA - Laboratório de } \\
\text { Estudos de Cidadania, } \\
\text { Territorialidade e } \\
\text { Ambiente }\end{array}$ & 1995 & $\begin{array}{l}\text { Políticas urbanas, direito } \\
\text { urbanístico e Gestão } \\
\text { Social das cidades }\end{array}$ & $\begin{array}{c}\text { Selene de Souza } \\
\text { Carvalho Herculano } \\
\text { dos Santos / } \\
\text { Napoleão Miranda }\end{array}$ \\
\hline $\begin{array}{l}\text { Universidade Federal } \\
\text { da Paraíba }\end{array}$ & $\begin{array}{l}\text { Grupo de Pesquisas } \\
\text { Subjetividade e Trabalho }\end{array}$ & 1996 & $\begin{array}{c}\text { Gestão Social e Políticas } \\
\text { Públicas }\end{array}$ & $\begin{array}{l}\text { Anísio José da Silva } \\
\text { Araújo / Paulo César } \\
\text { Zambroni de Souza }\end{array}$ \\
\hline
\end{tabular}




\begin{tabular}{|c|c|c|c|c|}
\hline $\begin{array}{l}\text { Universidade Federal } \\
\text { do Rio Grande do } \\
\text { Norte }\end{array}$ & $\begin{array}{l}\text { Grupo de Estudos e } \\
\text { Pesquisas em Gestão } \\
\text { Institucional e Políticas } \\
\text { Públicas }\end{array}$ & 1997 & $\begin{array}{c}\text { Gestão Pública, Políticas } \\
\text { de Inovação, Parcerias } \\
\text { Público-Privada e Gestão } \\
\text { Social }\end{array}$ & $\begin{array}{c}\text { Dinah dos Santos } \\
\text { Tinôco / } \\
\text { Maria Arlete Duarte } \\
\text { de Araujo }\end{array}$ \\
\hline $\begin{array}{l}\text { Pontifícia } \\
\text { Universidade } \\
\text { Católica de São } \\
\text { Paulo }\end{array}$ & $\begin{array}{l}\text { Núcleo de Estudos } \\
\text { Avançados do Terceiro } \\
\text { Setor- NEATS }\end{array}$ & 1998 & $\begin{array}{c}\text { Gestão Social, Redes } \\
\text { Sociais e } \\
\text { Intersetorialidade }\end{array}$ & $\begin{array}{l}\text { Luciano Antonio } \\
\text { Prates Junqueira / } \\
\text { Ladislas Dowbor }\end{array}$ \\
\hline $\begin{array}{l}\text { Pontifícia } \\
\text { Universidade } \\
\text { Católica de São } \\
\text { Paulo }\end{array}$ & $\begin{array}{l}\text { Núcleo de Estudos e } \\
\text { Pesquisas Trabalho e } \\
\text { Profissão }\end{array}$ & 1998 & $\begin{array}{l}\text { Política Social e Gestão } \\
\text { Social }\end{array}$ & $\begin{array}{l}\text { Raquel Raichelis } \\
\text { Degenszajn }\end{array}$ \\
\hline $\begin{array}{l}\text { Universidade Federal } \\
\text { do Rio Grande do Sul }\end{array}$ & $\begin{array}{l}\text { NIPETS - Núcleo } \\
\text { Interdisciplinar de } \\
\text { Pesquisas e Estudos Sobre } \\
\text { o Terceiro Setor }\end{array}$ & 1998 & $\begin{array}{c}\text { Gestão Social, } \\
\text { Tecnologias e Processos } \\
\text { Alternativos de Gestão, } \\
\text { Produção e }\end{array}$ & $\begin{array}{c}\text { Rosinha da Silva } \\
\text { Machado Carrion / } \\
\text { Pedro de Almeida } \\
\text { Costa }\end{array}$ \\
\hline $\begin{array}{l}\text { Universidade Federal } \\
\text { de Mato Grosso do } \\
\text { Sul }\end{array}$ & Engenharia de Software & 2001 & $\begin{array}{l}\text { Sistema de Informação } \\
\text { em Gestão Social }\end{array}$ & $\begin{array}{l}\text { Marcelo Augusto } \\
\text { Santos Turine / } \\
\text { Débora Maria } \\
\text { Barroso Paiva }\end{array}$ \\
\hline $\begin{array}{l}\text { Universidade do Vale } \\
\text { do Rio dos Sinos }\end{array}$ & $\begin{array}{l}\text { Grupo de Estudos em } \\
\text { Gestão Social, Mudanças, } \\
\text { Aprendizagem e } \\
\text { Competências } \\
\text { Organizacionais }\end{array}$ & 2002 & Gestão Social & $\begin{array}{l}\text { Claudia Cristina } \\
\text { Bitencourt }\end{array}$ \\
\hline $\begin{array}{l}\text { Universidade } \\
\text { Regional do Noroeste } \\
\text { do Estado do Rio } \\
\text { Grande do Sul }\end{array}$ & $\begin{array}{l}\text { Grupo Interdisciplinar de } \\
\text { Estudos em Gestão e } \\
\text { Políticas Públicas, } \\
\text { Desenvolvimento, } \\
\text { Comunicação e Cidadania } \\
\text { - GPDeC }\end{array}$ & 2002 & $\begin{array}{c}\text { Estado, esfera pública e } \\
\text { Gestão Social }\end{array}$ & $\begin{array}{l}\text { Sérgio Luís } \\
\text { Allebrandt }\end{array}$ \\
\hline $\begin{array}{l}\text { Pontifícia } \\
\text { Universidade } \\
\text { Católica de Minas } \\
\text { Gerais }\end{array}$ & $\begin{array}{l}\text { Núcleo de Pesquisa em } \\
\text { Ética e Gestão Social } \\
\text { (NUPEGS) }\end{array}$ & 2003 & $\begin{array}{c}\text { Gestão Social \& Gestão } \\
\text { Pública }\end{array}$ & $\begin{array}{l}\text { Armindo dos Santos } \\
\text { de Sousa Teodósio / } \\
\text { Roberto Patrus } \\
\text { Mundim Pena }\end{array}$ \\
\hline $\begin{array}{l}\text { Universidade Federal } \\
\text { da Bahia }\end{array}$ & $\begin{array}{l}\text { Centro Interdisciplinar de } \\
\text { Desenvolvimento e Gestão } \\
\text { Social- CIAGS }\end{array}$ & 2003 & $\begin{array}{c}\text { Ensino, Pesquisa e } \\
\text { Intervenção em Gestão } \\
\text { Pública e Gestão Social }\end{array}$ & $\begin{array}{c}\text { Tania Maria } \\
\text { Diederichs Fischer / } \\
\text { Maria Suzana de } \\
\text { Souza Moura }\end{array}$ \\
\hline $\begin{array}{l}\text { Universidade do Vale } \\
\text { do Itajaí }\end{array}$ & $\begin{array}{l}\text { Núcleo de Estudos } \\
\text { Interdisciplinares sobre o } \\
\text { Terceiro Setor }\end{array}$ & 2004 & $\begin{array}{l}\text { Gestão Social e } \\
\text { Empresarial }\end{array}$ & $\begin{array}{c}\text { Edilene Naciara } \\
\text { Pereira }\end{array}$ \\
\hline $\begin{array}{l}\text { Universidade Federal } \\
\text { da Bahia }\end{array}$ & $\begin{array}{l}\text { Laboratório de Estudos } \\
\text { Vinculares e Saúde } \\
\text { Mental }\end{array}$ & 2006 & $\begin{array}{l}\text { Subjetividade, vínculo, } \\
\text { fragilidades vinculares e } \\
\text { tecnologias de Gestão } \\
\text { Social. }\end{array}$ & $\begin{array}{l}\text { Marcus Vinicius de } \\
\text { Oliveira Silva / } \\
\text { Mônica Lima de } \\
\text { Jesus }\end{array}$ \\
\hline $\begin{array}{l}\text { Universidade Federal } \\
\text { de Viçosa }\end{array}$ & $\begin{array}{l}\text { Gestão e desenvolvimento } \\
\text { de cooperativas e } \\
\text { associações }\end{array}$ & 2006 & $\begin{array}{l}\text { Gestão Social de } \\
\text { organizações }\end{array}$ & $\begin{array}{c}\text { Nora Beatriz Presno } \\
\text { Amodeo }\end{array}$ \\
\hline $\begin{array}{l}\text { Universidade } \\
\text { Presbiteriana } \\
\text { Mackenzie }\end{array}$ & $\begin{array}{l}\text { Educação, Gestão e } \\
\text { Sociedade }\end{array}$ & 2006 & $\begin{array}{l}\text { Organizações, Gestão } \\
\text { Social e Educacional na } \\
\text { Contemporaneidade }\end{array}$ & $\begin{array}{l}\text { Mary Rosane Ceroni } \\
\text { / Berenice Carpigiani }\end{array}$ \\
\hline $\begin{array}{l}\text { Universidade Federal } \\
\text { de Lavras }\end{array}$ & $\begin{array}{l}\text { Administração Pública e } \\
\text { Gestão Social }\end{array}$ & 2007 & $\begin{array}{c}\text { Administração Pública e } \\
\text { Gestão Social }\end{array}$ & $\begin{array}{c}\text { Ana Alice Vilas Boas } \\
\text { / José Roberto } \\
\text { Pereira }\end{array}$ \\
\hline $\begin{array}{l}\text { Universidade Federal } \\
\text { de Rondônia }\end{array}$ & $\begin{array}{l}\text { Grupo de Estudos e } \\
\text { Pesquisas em } \\
\text { Organizações- GEPORG }\end{array}$ & 2007 & $\begin{array}{l}\text { Gestão Social: } \\
\text { Gerenciamento de } \\
\text { Politicas Sociais e }\end{array}$ & $\begin{array}{c}\text { José Moreira da Silva } \\
\text { Neto / Gleimiria } \\
\text { Batista da Costa }\end{array}$ \\
\hline
\end{tabular}


Simultaneidade da

Cidadania e

Governabilidade

\begin{tabular}{|c|c|c|c|c|}
\hline $\begin{array}{l}\text { Universidade Federal } \\
\text { de Viçosa }\end{array}$ & $\begin{array}{l}\text { Administração Pública e } \\
\text { Gestão Social }\end{array}$ & 2007 & $\begin{array}{c}\text { Administração Pública e } \\
\text { Gestão Social }\end{array}$ & $\begin{array}{c}\text { Ana Alice Vilas Boas } \\
\text { / José Roberto } \\
\text { Pereira }\end{array}$ \\
\hline $\begin{array}{l}\text { Pontifícia } \\
\text { Universidade } \\
\text { Católica do Rio } \\
\text { Grande }\end{array}$ & $\begin{array}{l}\text { FORMASS - Grupo de } \\
\text { Estudos sobre Gestão } \\
\text { Social e Formação em } \\
\text { Serviço Social }\end{array}$ & 2008 & $\begin{array}{c}\text { Gestão Social: Interfaces } \\
\text { com o Estado, o } \\
\text { Mercado e a Sociedade } \\
\text { Civil }\end{array}$ & $\begin{array}{c}\text { Ana Lúcia Suárez } \\
\text { Maciel }\end{array}$ \\
\hline $\begin{array}{l}\text { Universidade Federal } \\
\text { de Lavras }\end{array}$ & $\begin{array}{l}\text { Gênero e Diversidade em } \\
\text { Movimento }\end{array}$ & 2008 & $\begin{array}{c}\text { Administração pública e } \\
\text { Gestão Social }\end{array}$ & $\begin{array}{c}\text { Maria de Lourdes } \\
\text { Souza Oliveira / } \\
\text { Viviane Santos } \\
\text { Pereira }\end{array}$ \\
\hline $\begin{array}{l}\text { Universidade Federal } \\
\text { de Pernambuco }\end{array}$ & $\begin{array}{l}\text { NIECS - Núcleo } \\
\text { Interdisciplinar de Estudos } \\
\text { sobre Conhecimento e } \\
\text { Sociedade }\end{array}$ & 2008 & $\begin{array}{l}\text { Gestão Social e } \\
\text { Conhecimento }\end{array}$ & $\begin{array}{l}\text { Rezilda Rodrigues } \\
\text { Oliveira }\end{array}$ \\
\hline $\begin{array}{l}\text { Universidade Federal } \\
\text { do Rio de Janeiro }\end{array}$ & $\begin{array}{l}\text { GIS - Gestão de } \\
\text { Iniciativas Sociais }\end{array}$ & 2008 & $\begin{array}{c}\text { Gestão Social e Inovação } \\
\text { Social }\end{array}$ & $\begin{array}{l}\text { Roberto dos Santos } \\
\text { Bartholo Junior }\end{array}$ \\
\hline $\begin{array}{l}\text { Universidade Federal } \\
\text { do Tocantins }\end{array}$ & $\begin{array}{l}\text { Grupo de Estudos e } \\
\text { Pesquisas em Gestão } \\
\text { Social }\end{array}$ & 2008 & Gestão Social & $\begin{array}{l}\text { Airton Cardoso } \\
\text { Cançado }\end{array}$ \\
\hline $\begin{array}{l}\text { Universidade Federal } \\
\text { dos Vales do } \\
\text { Jequitinhonha e } \\
\text { Mucuri }\end{array}$ & $\begin{array}{l}\text { Núcleo de Estudos e } \\
\text { Pesquisa em Gestão e } \\
\text { Desenvolvimento } \\
\text { Regional - NEGED }\end{array}$ & 2009 & Gestão Social & $\begin{array}{c}\text { Naldeir dos Santos } \\
\text { Vieira / } \\
\text { Chams Maria } \\
\text { Kumaira }\end{array}$ \\
\hline $\begin{array}{l}\text { Instituto Federal do } \\
\text { Sudeste de Minas } \\
\text { Gerais }\end{array}$ & $\begin{array}{l}\text { Gestão Pública e } \\
\text { Desenvolvimento } \\
\text { socioambiental }\end{array}$ & 2010 & $\begin{array}{c}\text { Gestão Social e Políticas } \\
\text { Públicas }\end{array}$ & $\begin{array}{l}\text { Wildson Justiniano } \\
\text { Pinto / Bruno Silva } \\
\text { Olher }\end{array}$ \\
\hline $\begin{array}{l}\text { Universidade do } \\
\text { Estado da Bahia }\end{array}$ & $\begin{array}{l}\text { Educação Ambiental, } \\
\text { Políticas Públicas e } \\
\text { Gestão Social dos } \\
\text { Territórios }\end{array}$ & 2010 & $\begin{array}{c}\text { Educação Ambiental e } \\
\text { Gestão Social dos } \\
\text { Territórios }\end{array}$ & $\begin{array}{l}\text { Avelar Luiz Bastos } \\
\text { Mutim / Célia } \\
\text { Tanajura Machado }\end{array}$ \\
\hline $\begin{array}{l}\text { Universidade Federal } \\
\text { de Santa Maria }\end{array}$ & $\begin{array}{l}\text { Grupo de Estudos e } \\
\text { Pesquisas em Gestão }\end{array}$ & 2010 & $\begin{array}{l}\text { Gestão Social e Gestão } \\
\text { da Diversidade }\end{array}$ & $\begin{array}{l}\text { Ana Elizabeth } \\
\text { Moiseichyk }\end{array}$ \\
\hline $\begin{array}{l}\text { Universidade de } \\
\text { Cuiabá }\end{array}$ & $\begin{array}{l}\text { Inovação Sustentável e } \\
\text { Desenvolvimento Social }\end{array}$ & 2011 & $\begin{array}{l}\text { Produção e Gestão } \\
\text { Social de Cidades } \\
\text { Sustentáveis }\end{array}$ & $\begin{array}{c}\text { Ana Paula Melo } \\
\text { Mariano / Pedro } \\
\text { Costa Campos Filho }\end{array}$ \\
\hline $\begin{array}{l}\text { Universidade Federal } \\
\text { da Bahia }\end{array}$ & $\begin{array}{l}\text { Processos de Inovação e } \\
\text { Aprendizagem em } \\
\text { Políticas Públicas e } \\
\text { Gestão Social }\end{array}$ & 2011 & $\begin{array}{l}\text { Formação em Gestão } \\
\text { Pública e Gestão Social }\end{array}$ & $\begin{array}{l}\text { Rosana de Freitas } \\
\text { Boullosa / Edgilson } \\
\text { Tavares de Araújo }\end{array}$ \\
\hline $\begin{array}{l}\text { Instituto Federal de } \\
\text { Educação Ciência e } \\
\text { Tecnologia do Norte } \\
\text { de Minas Gerais }\end{array}$ & $\begin{array}{l}\text { Núcleo de Pesquisa e } \\
\text { Extensão em } \\
\text { Administração Pública e } \\
\text { Gestão Social }\end{array}$ & 2012 & $\begin{array}{c}\text { Ensino, Pesquisa e } \\
\text { Extensão em Gestão } \\
\text { Pública e Gestão Social }\end{array}$ & $\begin{array}{c}\text { André Aristóteles da } \\
\text { Rocha Muniz / } \\
\text { Hélder Seixas Lima }\end{array}$ \\
\hline $\begin{array}{l}\text { Universidade Federal } \\
\text { do Amazonas }\end{array}$ & $\begin{array}{l}\text { Grupo de Pesquisa em } \\
\text { Gestão Social, Direitos } \\
\text { Humanos e } \\
\text { Sustentabilidade na } \\
\text { Amazônia. }\end{array}$ & 2012 & $\begin{array}{l}\text { Gestão Social, Políticas } \\
\text { Públicas, Ambiente e } \\
\text { Sustentabilidade; }\end{array}$ & $\begin{array}{c}\text { Marinez Gil } \\
\text { Nogueira / Lucilene } \\
\text { Ferreira de Melo }\end{array}$ \\
\hline
\end{tabular}




\begin{tabular}{|c|c|c|c|c|}
\hline $\begin{array}{l}\text { Universidade da } \\
\text { Integração } \\
\text { Internacional da } \\
\text { Lusofonia Afro- } \\
\text { Brasileira }\end{array}$ & $\begin{array}{l}\text { Pega Teço - } \\
\text { Desenvolvimento, } \\
\text { Cidadania e Políticas } \\
\text { Públicas }\end{array}$ & 2013 & Gestão Social & $\begin{array}{c}\text { Marilia De } \\
\text { Franceschi Neto } \\
\text { Domingos / Maria } \\
\text { Vilma Coelho } \\
\text { Moreira Faria }\end{array}$ \\
\hline $\begin{array}{l}\text { Universidade do } \\
\text { Estado de Minas } \\
\text { Gerais }\end{array}$ & $\begin{array}{l}\text { NEPHES - Núcleo de } \\
\text { ensino e pesquisa em } \\
\text { História Educação e } \\
\text { Sociedade }\end{array}$ & 2013 & $\begin{array}{l}\text { Gestão Social e } \\
\text { Organizacional }\end{array}$ & $\begin{array}{c}\text { Edna Mara Ferreira } \\
\text { da Silva }\end{array}$ \\
\hline $\begin{array}{l}\text { Universidade Federal } \\
\text { de Minas Gerais }\end{array}$ & $\begin{array}{l}\text { Grupo de Estudos } \\
\text { Ergologia, Trabalho e } \\
\text { Desenvolvimento }\end{array}$ & 2013 & $\begin{array}{c}\text { Gestão Social, Políticas } \\
\text { Públicas e } \\
\text { Desenvolvimento }\end{array}$ & $\begin{array}{c}\text { Daisy Moreira Cunha } \\
\text { / Mariana Veríssimo } \\
\text { Soares de Aguiar e } \\
\text { Silva }\end{array}$ \\
\hline $\begin{array}{l}\text { Universidade Federal } \\
\text { Fluminense }\end{array}$ & $\begin{array}{l}\text { LATOS: Laboratório de } \\
\text { Estudos em Trabalho, } \\
\text { Organizações e Sociedade }\end{array}$ & 2013 & $\begin{array}{c}\text { NDGS - Núcleo } \\
\text { Democracia } \\
\text { Participativa, Governo e } \\
\text { Gestão Social }\end{array}$ & $\begin{array}{c}\text { Júlio Cesar Andrade } \\
\text { de Abreu / } \\
\text { Luís Henrique } \\
\text { Abegão }\end{array}$ \\
\hline $\begin{array}{l}\text { Universidade Federal } \\
\text { Rural do Rio de } \\
\text { Janeiro }\end{array}$ & $\begin{array}{l}\text { Laboratório de Pesquisa } \\
\text { em Desenvolvimento } \\
\text { Territorial e Políticas } \\
\text { Públicas }\end{array}$ & 2013 & $\begin{array}{c}\text { Gestão Social e } \\
\text { Desenvolvimento } \\
\text { Territorial no município } \\
\text { de Itaguaí }\end{array}$ & $\begin{array}{l}\text { Lamounier Erthal } \\
\text { Villela }\end{array}$ \\
\hline $\begin{array}{l}\text { Centro Universitário } \\
\text { UNA }\end{array}$ & $\begin{array}{l}\text { Trabalho-educação e } \\
\text { desenvolvimento local }\end{array}$ & 2014 & $\begin{array}{c}\text { Gestão Social do } \\
\text { trabalho e } \\
\text { desenvolvimento local }\end{array}$ & $\begin{array}{c}\text { Eloisa Helena Santos } \\
\text { / Deise de Souza } \\
\text { Dias }\end{array}$ \\
\hline $\begin{array}{l}\text { Universidade do } \\
\text { Estado da Bahia }\end{array}$ & $\begin{array}{l}\text { Grupo de Estudos e } \\
\text { Pesquisa em Gestão } \\
\text { Organizacional e Inovação }\end{array}$ & 2014 & $\begin{array}{l}\text { Desenvolvimento e } \\
\text { Gestão Social }\end{array}$ & $\begin{array}{l}\text { Maria de Fátima } \\
\text { Araújo Frazão }\end{array}$ \\
\hline $\begin{array}{l}\text { Universidade } \\
\text { Estadual Paulista } \\
\text { Júlio de }\end{array}$ & $\begin{array}{l}\text { Grupo de Pesquisa em } \\
\text { Democracia e Gestão } \\
\text { Social }\end{array}$ & 2014 & $\begin{array}{l}\text { Desenvolvimento, } \\
\text { Gestão Social e } \\
\text { Ambiental }\end{array}$ & $\begin{array}{l}\text { Nelson Russo de } \\
\text { Moraes / Sergio Silva } \\
\text { Braga Junior }\end{array}$ \\
\hline $\begin{array}{l}\text { Universidade Federal } \\
\text { do Oeste do Pará }\end{array}$ & $\begin{array}{l}\text { Grupo de Pesquisa } \\
\text { Socioantropologia da } \\
\text { Pesca no Baixo Amazonas }\end{array}$ & 2015 & $\begin{array}{c}\text { Comunidades } \\
\text { ribeirinhas, Gestão } \\
\text { Social da água e } \\
\text { mobilização política } \\
\text { popular }\end{array}$ & Rubens Elias da Silva \\
\hline $\begin{array}{l}\text { Universidade } \\
\text { Estadual do Oeste do } \\
\text { Paraná }\end{array}$ & $\begin{array}{l}\text { Grupo de Estudos e } \\
\text { Pesquisa em Gestão } \\
\text { Social, Inovação, Cultura } \\
\text { e Religião }\end{array}$ & 2016 & $\begin{array}{c}\text { Gestão Social como } \\
\text { articulador dos processos } \\
\text { de intervenção social nos } \\
\text { espaços espaços e } \\
\text { organizações públicas, } \\
\text { privadas e da sociedade } \\
\text { civil } \\
\end{array}$ & $\begin{array}{c}\text { Edson Marques } \\
\text { Oliveira }\end{array}$ \\
\hline
\end{tabular}

Fonte: Diretório dos Grupos de Pesquisa no Brasil - Lattes - CNPq

Sabe-se que há grupos de pesquisa que têm a Gestão Social como objeto de estudo, no entanto não apresentam o termo "Gestão Social" nem em sua denominação nem em suas linhas de pesquisa. A intenção desta seção foi realizar um mapeamento da institucionalização dos grupos de pesquisa em Gestão Social. 


\subsubsection{Principais temáticas de investigação}

Em sua tese de doutorado, Cançado (2011) estabeleceu categorias teóricas que compõem o campo da Gestão Social. Segundo Cançado (2011), "a criação das categorias de análise baseou-se no tratamento, em termos de significação, dado ao termo Gestão Social. O objetivo principal deste trabalho é construir as categorias teóricas para a Gestão Social como campo do conhecimento científico". Primeiramente, Cançado (2011) definiu a categoria "Gestão Social (GS)" para extrair a delimitação do termo e posteriormente estabeleceu outras categorias para analisar textos que não tratavam conceitualmente da Gestão Social, mas que eram importantes para construir um mapa da utilização do termo. As categorias de análise definidas foram: Gestão Emancipatória (GE), Gestão Participativa (GP), Gestão do Desenvolvimento Social (GDS), Gestão em Organizações Sem Fins Lucrativos (GOSFL), Gestão da Responsabilidade Social Empresarial (GRSE), Formação em Gestão Social (FGS) e Outras Formas de Gestão Relacionadas (OFGR).

Podemos também verificar as temáticas da área de Gestão Social por meio dos eixos temáticos do Encontro Nacional de Pesquisadores em Gestão Social (ENAPEGS), conforme quadro abaixo.

\section{Quadro 6: Temas e eixos temáticos do Encontro Nacional de Pesquisadores em Gestão Social (ENAPEGS) de 2007 a 2014}

\begin{tabular}{|c|c|c|c|}
\hline Ano & Tema & $\begin{array}{c}\text { Local de } \\
\text { realização }\end{array}$ & Eixos Temáticos \\
\hline 2007 & $\begin{array}{l}\text { Gestão Social: Práticas } \\
\text { em Debate e Teorias } \\
\text { em Construção }\end{array}$ & $\begin{array}{l}\text { Juazeiro do } \\
\text { Norte (CE) }\end{array}$ & $\begin{array}{l}\text { Teorias em Construção } \\
\text { Práticas em Debate } \\
\text { Perspectivas e Desafios }\end{array}$ \\
\hline 2008 & $\begin{array}{l}\text { Os Desafios da } \\
\text { Formação em Gestão } \\
\text { Social }\end{array}$ & Palmas (TO) & $\begin{array}{l}\text { Epistemologia e Metodologias } \\
\text { Redes Sociais e Desenvolvimento Territorial } \\
\text { Economia Solidária e Cooperativismo } \\
\text { Empreendedorismo Social } \\
\text { Responsabilidade Socioambiental }\end{array}$ \\
\hline 2009 & $\begin{array}{l}\text { Gestão Social e } \\
\text { Políticas Públicas de } \\
\text { Desenvolvimento: } \\
\text { Ações, Articulações } \\
\text { e Agenda }\end{array}$ & $\begin{array}{c}\text { Juazeiro }(\mathrm{BA}) \mathrm{e} \\
\text { Petrolina } \\
(\mathrm{PE})\end{array}$ & $\begin{array}{l}\text { Gestão Social e Políticas Públicas } \\
\text { Economia Solidária e Cooperativismo } \\
\text { Responsabilidade Socioambiental } \\
\text { Movimentos Sociais e Ações Afirmativas } \\
\text { Ensino e Pesquisa em Gestão Social }\end{array}$ \\
\hline
\end{tabular}


Oficinas - Tecnologias Sociais, Experiências, Ensino e Metodologias em Gestão Social

Debates em Gestão Social

\begin{tabular}{|c|c|c|c|}
\hline \multirow{8}{*}{2010} & \multirow{8}{*}{$\begin{array}{l}\text { Gestão Social e } \\
\text { Gestão Pública: } \\
\text { Interfaces e } \\
\text { Delimitações }\end{array}$} & \multirow{8}{*}{ Lavras (MG) } & Gestão Social e Políticas Públicas \\
\hline & & & $\begin{array}{l}\text { Redes, Arranjos Institucionais e Desenvolvimento } \\
\text { Territorial }\end{array}$ \\
\hline & & & Sustentabilidade e Gestão Socioambiental \\
\hline & & & Empreendedorismo Social \\
\hline & & & Inovação e Tecnologias Sociais \\
\hline & & & Economia Solidária e Cooperativismo \\
\hline & & & Ensino e Pesquisa em Gestão Social \\
\hline & & & Diversidade, Movimentos Sociais e Ações Afirmativas \\
\hline
\end{tabular}

Coprodução e Inovação Social na Esfera Pública;

Gestão Social, Redes e Movimentos Sociais;

"Democracias" nos processos de construção de "Outras

Gestão Social como

Caminho para a

Redefinição da Esfera

Pública
Florianópolis

(SC)
Economias": Trilhas para a Redefinição da Esfera Pública;

Gestão Social, Arte e Cultura: valores e tecnologias para a gestão do patrimônio das cidades;

O papel das Metodologias Integrativas na ampliação da esfera pública;

Construção da teoria do conhecimento em Gestão Social;

Filosofia da diferença, biopolítica, produção de subjetividade;

Ensino, pesquisa e extensão em Gestão Social.

\begin{tabular}{|c|c|c|c|}
\hline \multirow{6}{*}{2012} & \multirow{6}{*}{$\begin{array}{l}\text { Gestão Social: } \\
\text { Mobilizações e } \\
\text { Conexões }\end{array}$} & \multirow{6}{*}{ São Paulo (SP) } & Economia Solidária e Cooperativismo \\
\hline & & & Gestão Social, Políticas Públicas e Território \\
\hline & & & Movimentos Sociais na Construção da Democracia \\
\hline & & & Ensino, Pesquisa e Extensão em Gestão Social \\
\hline & & & Sustentabilidade, Mercado e Sociedade \\
\hline & & & Inovações e Tecnologias Sociais \\
\hline \multirow{6}{*}{2013} & \multirow{6}{*}{$\begin{array}{l}\text { Territórios em } \\
\text { Movimento: } \\
\text { Caminhos e } \\
\text { Descaminhos da } \\
\text { Gestão Social e } \\
\text { Ambiental }\end{array}$} & \multirow{6}{*}{ Belém (PA) } & Governança Ambiental e Territorial \\
\hline & & & Economia Solidária e Cooperativismo \\
\hline & & & Gestão Social das Políticas Públicas \\
\hline & & & Redes e Movimentos Sociais na Construção da Cidadania \\
\hline & & & Sustentabilidade, Mercado e Sociedade \\
\hline & & & Ensino, Pesquisa e Extensão em Gestão Social \\
\hline \multirow{3}{*}{2014} & \multirow{3}{*}{$\begin{array}{l}\text { Gestão Social e } \\
\text { Interdisciplinaridade: } \\
\text { construindo novas } \\
\text { pontes e expandindo } \\
\text { fronteiras }\end{array}$} & \multirow{3}{*}{ Cachoeira (BA) } & Gestão Social, Formação e Culturas \\
\hline & & & Gestão Social, Economia e Trabalho \\
\hline & & & $\begin{array}{l}\text { Gestão Social, Políticas Públicas, Desenvolvimento e } \\
\text { Relações Estado-Sociedade }\end{array}$ \\
\hline
\end{tabular}


Durante a primeira edição em 2007, percebe-se um esforço no sentido de apresentar a área da Gestão Social e iniciar o debate sobre sua conceituação. Nos anos seguintes, podemos observar a ampliação dos eixos temáticos, remetendo à segunda geração, abordada em seção anterior. Nesse período, a ampliação dos temas significava a afirmação da área e sua institucionalização. Por fim, podemos notar uma diminuição dos eixos temáticos, o que coincide com o movimento, iniciado pela terceira geração, pela depuração e definição do conceito. 


\section{PROCEDIMENTOS METODOLÓGICOS}

Neste capítulo serão apresentados os procedimentos metodológicos empregados na pesquisa, seguindo a seguinte estrutura: i) natureza do estudo; ii) métodos, subdividindo-se este em a) definição da base de dados e b) procedimento de análise dos dados.

\subsection{Natureza do estudo}

O presente trabalho tem como objetivo mapear e construir a rede de produção científica do campo do saber em Gestão Social na última década e para isso buscará compreender os fundamentos teóricos da Gestão Social; analisar a produção científica dos pesquisadores de Gestão Social; e descrever os fenômenos observados a partir da produção da comunidade científica. Desta forma, podemos dizer que a pesquisa terá natureza exploratória, descritiva e explicativa.

A pesquisa exploratória tem como objetivo proporcionar maior familiaridade com o tema da Gestão Social e apresentar uma caracterização do campo científico, por meio do levantamento bibliográfico e documental e entrevistas.

A pesquisa bibliográfica visa proporcionar a compreensão dos fundamentos teóricos da Gestão Social e uma maior familiaridade com o tema. Para isso, pesquisaram-se artigos relacionados ao tema na base de dados SciELO - Scientific Electronic Library Online utilizando-se como palavra chave o termo "Gestão Social". Outra fonte pesquisada foram os livros publicados após a realização do Encontro Nacional de Pesquisadores em Gestão Social - ENAPEGS, denominados "Coleção ENAPEGS". Além da compreensão dos temas relacionados à Gestão Social, será realizado um levantamento bibliográfico para explorar o tema das redes complexas e de estudos bibliométricos, já que um dos objetivos é construção da rede de produção científica do campo de Gestão Social.

A pesquisa documental utilizará a produção científica dos autores do campo científico de Gestão Social para apontar as configurações do campo. Também serão analisados, para esta finalidade, os anais do Encontro Nacional de Pesquisadores em Gestão Social - 
ENAPEGS, com o objetivo de identificar os pesquisadores participantes e temas abordados, por exemplo.

As entrevistas foram realizadas com alguns pesquisadores do campo da Gestão Social. O objetivo das entrevistas é ter uma visão dos pesquisadores sobre o campo e a validação dos eventos e periódicos que serão utilizados no mapeamento e na construção da rede de produção científica do campo de Gestão Social. Para Gil (2008), “o que se pretende com entrevistas deste tipo é a obtenção de uma visão geral do problema pesquisado, bem como a identificação de alguns aspectos da personalidade do entrevistado".

A pesquisa descritiva utilizará os dados coletados na pesquisa documental para caracterização da configuração do campo científico, distinguindo suas peculiaridades e apresentando suas principais características. Segundo Gil (2008), “as pesquisas deste tipo têm como objetivo primordial a descrição das características de determinada população ou fenômeno ou o estabelecimento de relações entre variáveis".

Para Gil (2008), as pesquisas explicativas "são aquelas que têm como preocupação central identificar os fatores que determinam ou que contribuem para a ocorrência dos fenômenos". Portanto, esta fase da pesquisa possibilitará a discussão detalhada dos fenômenos observados para assim constituir um trabalho cujas considerações esclareçam as motivações e os objetivos elencados.

\subsection{Métodos}

\subsubsection{Definição das bases de dados}

As bases de dados que serão utilizadas nesta pesquisa foram selecionadas segundo o critério de acolherem trabalhos científicos na área de Gestão Social. O período definido para a coleta de dados foi de 2005 a 2015, totalizando um intervalo de onze anos. O corte temporal, tendo como ano inicial 2005, coincide com a criação, neste ano, da divisão de Administração Pública e Gestão Social no Encontro da Associação Nacional de Pós-Graduação e Pesquisa em Administração (EnANPAD). A coleta de dados será feita a partir de websites e CD-ROMs 
dos periódicos e dos eventos e da Plataforma Lattes. A seguir apresentaremos brevemente os eventos e periódicos selecionados para a análise.

\subsubsection{Eventos}

EnANPAD

O Encontro da Associação Nacional de Pós-Graduação e Pesquisa em Administração (EnANPAD) vem sendo realizado anualmente desde 1977. No ano de 2016, realizará, portanto, sua XL edição. Em 2003, foi criada a divisão Gestão Social e Ambiental e, em 2005, foi criada a divisão Administração Pública e Gestão Social, ficando a antiga divisão "Gestão Social e Ambiental" como uma subárea desta mais recente. No entanto, essa divisão existiu até o ano de 2009, tendo sido transformada em "Administração Pública" no ano seguinte, e Gestão Social não entrou sequer como tema de interesse da divisão.

\section{EnAPG}

O EnAPG - Encontro de Administração Pública e Governança da Associação Nacional de Pós-Graduação e Pesquisa em Administração é mais recente e encontra-se em sua VI edição. Este encontro é realizado bianualmente e teve sua primeira edição ocorrida no ano de 2004. Segundo informações institucionais, o evento é uma iniciativa da divisão acadêmica de Administração Pública e Gestão Social da ANPAD, a qual foi delineada a partir do $27^{\circ}$ Congresso Nacional da ANPAD, ocorrido em 2003. A iniciativa surgiu em decorrência de diversos encontros informais entre integrantes e coordenadores das duas áreas e da avaliação conjunta sobre a importância e oportunidade do debate comum das temáticas afetas a esfera pública.

\section{ENAPEGS}

O Encontro Nacional de Pesquisadores em Gestão Social (ENAPEGS), segundo informações institucionais do site do encontro, é um fórum de encontro de pesquisadores, estudantes, profissionais e atores sociais envolvidos ou interessados em debater formas dialógicas, deliberativas, mobilizadoras e emancipadoras de gestão das organizações, reunidas 
sob o signo de Gestão Social. O ENAPEGS é realizado pela Rede de Pesquisadores de Gestão Social (RGS) e organizado por centros de pesquisa na área de Gestão Social, nas cidades que o sedia, desde 2007. Em 2014, foi realizada sua VIII edição e nesta data também ficou deliberado que o evento, a partir dali, seria bianual.

\section{EMAPEGS}

O Encontro Mineiro de Administração Pública, Economia Solidária e Gestão Social (EMAPEGS), segundo o site da edição de 2013, vem se consolidando como um dos mais importantes eventos em Administração Pública em Minas Gerais. Suas quatro edições (2009, 2010, 2012, 2013 e 2015) foram realizadas na Universidade Federal de Lavras (UFLA) e Universidade Federal de Viçosa (UFV), alternadamente. O objetivo do encontro é ser um espaço aberto de reflexão, diálogo e sensibilização em torno dessas temáticas ainda pouco exploradas. Embora o encontro tenha tido cinco edições, para fins desta pesquisa consideraremos apenas a edição de 2015, já que o ENAPEGS, o principal evento do campo da Gestão Social, deixou de ser anual, não ocorrendo no ano de 2015. Desta forma, o EMAPEGS foi considerado o principal evento de Gestão Social no citado ano.

\section{Colóquio Internacional sobre o Poder Local}

O Colóquio Internacional sobre o Poder Local é uma iniciativa do Núcleo de Estudos sobre Poder e Organizações Locais (NEPOL), um núcleo de estudos e pesquisas vinculado ao Núcleo de Pós-Graduação - NPGA da Escola de Administração da Universidade Federal da Bahia. Segundo informações institucionais, desde 1986, o eixo principal do Colóquio é a análise dos poderes locais vistos, pelo menos, em três dimensões: como recortes e escalas territoriais, como espaços simbólicos e como espaços de gestão. 


\subsubsection{Periódicos}

Revista de Administração Pública (RAP)

A Revista de Administração Pública (RAP) foi fundada em 1967, no âmbito da Fundação Getúlio Vargas. O periódico acolhe contribuições das áreas de Administração e Desenvolvimento; Administração Pública; Ciências Humanas, Sociais e Sociais Aplicadas; Estudos Organizacionais; Gestão Social; Movimentos Sociais; Política Pública.

\section{Revista Organizações \& Sociedade $(O \& S)$}

A Revista Organizações \& Sociedade (O\&S), fundada em 1993, é uma publicação da Escola de Administração da Universidade Federal da Bahia (EAUFBA). Segundo a sessão de foco e escopo no site do periódico, a revista contempla artigos sobre organizações públicas, privadas e do terceiro setor, que abrangem a inter, multi e transdisciplinariedade, articulando dialeticamente as organizações no contexto de compreensão da sociedade contemporânea.

\section{Cadernos EBAPE.BR}

O Cadernos EBAPE.BR, publicado pela primeira vez em 2003, é um periódico online com foco na área de Administração, patrocinado pela Escola Brasileira de Administração Pública e de Empresas da Fundação Getúlio Vargas. Segundo a política editorial, o escopo editorial do periódico é o de promover o debate de temas relevantes para a construção do conhecimento no âmbito da Administração com base em abordagens interdisciplinares e críticas.

\section{Administração Pública e Gestão Social (APGS)}

A Administração Pública e Gestão Social (APGS) é um periódico online com periodicidade trimestral e teve sua primeira publicação realizada em 2009. A revista publica artigos nas áreas de Administração Pública, Gestão Social e Terceiro Setor. 
Revista Interdisciplinar de Gestão Social (RIGS)

A Revista Interdisciplinar de Gestão Social (RIGS) é uma publicação eletrônica, fundada em 2012, com periodicidade quadrimestral, vinculada ao Centro Interdisciplinar de Desenvolvimento e Gestão Social (CIAGS) da Escola de Administração da Universidade Federal da Bahia (UFBA).

\section{NAU Social}

A NAU Social é uma revista online, fundada em 2010, vinculada ao Centro Interdisciplinar de Desenvolvimento e Gestão Social (CIAGS) da Escola de Administração da Universidade Federal da Bahia (UFBA). O periódico acolhe contribuições de diferentes formatos relacionados à formação em Gestão Social e políticas públicas, com suas áreas correlacionadas, com ênfase na inovação e aprendizagem, buscando contribuir para a discussão acerca da natureza e fronteiras de ambos os campos.

\section{Cadernos de Gestão Social (CGS)}

O periódico Cadernos de Gestão Social (CGS) foi criado em 2007 pelo Centro Interdisciplinar de Desenvolvimento e Gestão Social (CIAGS), da Escola de Administração da Universidade Federal da Bahia (EA/UFBA). O periódico acolhe trabalhos com temáticas afins da Gestão Social na sua variedade de sub-temas, teorias e práticas em diferentes setores, espaços territoriais e tipos organizacionais.

\section{Cadernos de Gestão Pública e Cidadania $(C G P \& C)$}

Cadernos Gestão Pública e Cidadania (CGP\&C) é um periódico online, cujo principal objetivo é divulgar trabalhos acadêmicos sobre gestão e políticas públicas. Publicado semestralmente pelo Centro de Estudos em Administração Pública e Governo e pelo Departamento de Gestão Pública da Escola de Administração de Empresas de São Paulo da Fundação Getulio Vargas (FGV-EAESP), teve seu primeiro número publicado em 1997. 


\subsubsection{Critérios de seleção dos artigos e trabalhos}

Como a maioria dos eventos e periódicos não acolhem exclusivamente artigos e trabalhos na temática da Gestão Social, definimos que os artigos e trabalhos seriam selecionados de acordo com os eixos temáticos do Enapegs 2010 e 2014, alguns temas do EnANPAD 2016 e dos verbetes Gestão Social, do Dicionário para a Formação em Gestão Social (Boullosa, 2014). Vale destacar que, para os eventos Enapegs e Emapegs, e para os periódicos RIGS, Cadernos de Gestão Social (CGS) e NAU Social, optamos por selecionar todos os artigos e trabalhos, por se tratarem de eventos e periódicos "puro sangue" de Gestão Social. Em relação ao EnANPAD, utilizamos um método híbrido: de 2005 a 2009, selecionamos todos os trabalhos apenas do tema Gestão Social e Ambiental, do eixo Administração Pública e Social; de 2010 a 2015, selecionamos trabalhos de todos os eixos, de acordo com os critérios de seleção citados acima.

\section{Eixos temáticos Enapegs 2010}

- Ensino e Pesquisa em Gestão Social

- Desafios da formação em gestão social

- Capacidades e perfis de competências específicas do gestor social

○ Ensino e pesquisa em gestão social

- Diversidade, Movimentos Sociais e Ações Afirmativas

- Discutir o emprego do gênero e da raça como construtores de identidades sociais

- Democracia racial

- Ações afirmativas

- Políticas públicas relacionadas aos portadores de necessidades especiais

\section{Eixos temáticos Enapegs 2014}

- Gestão Social, Formação e Culturas

- Cultura, arte e criatividade na Gestão Social

- Gestão Social de Políticas Culturais

- Gestão Social, patrimônio e território: a experiência de comunidades tradicionais 
- Práticas inovadoras da Gestão Social em questões de gênero e diversidade sexual

○ Políticas de educação superior: interiorização, acesso e permanência

○ Gestão Social e educação do campo

- Gestão Social, Economia e Trabalho

- Cooperativismo e Economia Solidária

- Empreendedorismo social e a Gestão Social: interfaces teóricas e práticas em curso

- Tecnologias sociais: concepções, experiências e impactos no contexto brasileiro

○ Sustentabilidade, mercado e sociedade

- Responsabilidade social corporativa política e implicações para Gestão Social

- Trabalho, competências e empoderamento: refletindo sobre cidadania na Gestão Social

○ Gestão Social, trabalho e dominação capitalista

- Gestão Social, Políticas Públicas, Desenvolvimento e Relações Estado-Sociedade

○ Movimentos sociais, democracia e Gestão Social

○ Juventudes e participação política

○ Modelos de proteção social e políticas sociais no campo da seguridade social brasileira

○ Tendências no campo de públicas

- Gestão Social e governança territorial e ambiental em contextos locais ou regionais

○ Gestão Social do desenvolvimento: a perspectiva do território

○ Estado como indutor do desenvolvimento e ação pública: espaços de diálogo, decisão e ação

Temas da Divisão de Administração Pública do EnANPAD 2016

Tema 02 - Relações entre Estado e Sociedade: relações entre Estado e organizações do terceiro setor, da economia solidária, não-governamentais, da sociedade civil e sem fins lucrativos. Espaço público e instituições participativas formais e informais. Governança democrática, relações com atores interessados e mecanismos de controle social. Cultura 
política, capital social e coprodução de bens públicos. Desenvolvimento local e ação de organizações públicas não-estatais. Governo aberto.

Tema 11 - Interfaces entre Gestão Pública e Gestão Social: Gestão Social, administração pública e desenvolvimento: interseções e distinções teórico-metodológicas. Gestão Social, governança e políticas públicas. Gestão Social em programas e projetos de desenvolvimento sustentável - dimensões social, ambiental e territorial. Gestão Social em políticas culturais. Gestão de políticas sociais: desigualdade, justiça e democracia. Ação coletiva e cooperação. Cidadania ativa, participação e ação pública. Gestão Social e controle social em ambientes públicos coletivos: fóruns, colegiados e conselhos.

\section{Quadro 7: Temas para a seleção dos artigos}

\begin{tabular}{|c|c|c|c|c|}
\hline \multicolumn{5}{|c|}{ Eixo 1: Gestão Social, Formação e Culturas } \\
\hline \multirow{2}{*}{$\begin{array}{c}\text { Grupos de Trabalho } \\
\text { Cultura, arte e } \\
\text { criatividade na gestão } \\
\text { social }\end{array}$} & \multicolumn{4}{|c|}{ Temas Chave } \\
\hline & $\begin{array}{c}\text { tripé arte, cultura e } \\
\text { criatividade no campo da } \\
\text { gestão social }\end{array}$ & metodologias integrativas & participação & \\
\hline $\begin{array}{c}\text { Gestão Social de Políticas } \\
\text { Culturais }\end{array}$ & $\begin{array}{c}\text { políticas culturais e a } \\
\text { gestão social de } \\
\text { equipamentos, } \\
\text { organizações e ações } \\
\text { culturais } \\
\end{array}$ & $\begin{array}{l}\text { institucionalização de } \\
\text { políticas culturais }\end{array}$ & gestão pública da cultura & planejamento em Cultura \\
\hline $\begin{array}{c}\text { Gestão Social, } \\
\text { patrimônio e território: a } \\
\text { experiência de } \\
\text { comunidades } \\
\text { tradicionais }\end{array}$ & $\begin{array}{c}\text { gestão social em } \\
\text { comunidades tradicionais }\end{array}$ & $\begin{array}{c}\text { gestão do patrimônio } \\
\text { cultural em comunidades } \\
\text { tradicionais }\end{array}$ & $\begin{array}{l}\text { experiências de } \\
\text { empreendedorismo social } \\
\text { e/ou de cooperativismos }\end{array}$ & $\begin{array}{c}\text { fortalecimento de } \\
\text { sentimentos de } \\
\text { identidade e continuidade }\end{array}$ \\
\hline $\begin{array}{l}\text { Práticas inovadoras da } \\
\text { gestão social em } \\
\text { questões de gênero e } \\
\text { diversidade sexual } \\
\end{array}$ & $\begin{array}{l}\text { temáticas relativas a } \\
\text { gênero e diversidade } \\
\text { sexual em contextos } \\
\text { organizacionais } \\
\end{array}$ & $\begin{array}{l}\text { práticas de gestão } \\
\text { pública, privada ou } \\
\text { terceiro setor }\end{array}$ & $\begin{array}{l}\text { políticas públicas } \\
\text { inovadoras }\end{array}$ & \\
\hline $\begin{array}{l}\text { Políticas de educação } \\
\text { superior: interiorização, } \\
\text { acesso e permanência }\end{array}$ & $\begin{array}{l}\text { políticas de educação } \\
\text { superior }\end{array}$ & políticas de interiorização & $\begin{array}{l}\text { acesso e permanência na } \\
\text { Educação Superior }\end{array}$ & \\
\hline $\begin{array}{c}\text { Gestão Social e educação } \\
\text { do campo }\end{array}$ & $\begin{array}{c}\text { projeto pedagógico e } \\
\text { avaliação da } \\
\text { aprendizagem }\end{array}$ & $\begin{array}{c}\text { agroecologia e } \\
\text { desenvolvimento agrário }\end{array}$ & $\begin{array}{c}\text { economia solidária e } \\
\text { políticas públicas do } \\
\text { campo }\end{array}$ & \\
\hline \multicolumn{5}{|c|}{ Eixo 2: Gestão Social, Economia e Trabalho } \\
\hline Grupos de Trabalho & \multicolumn{4}{|c|}{ Temas Chave } \\
\hline $\begin{array}{l}\text { Cooperativismo e } \\
\text { Economia Solidária }\end{array}$ & cooperativismo popular & autogestão & $\begin{array}{l}\text { redes e cadeias } \\
\text { produtivas solidárias }\end{array}$ & \\
\hline $\begin{array}{c}\text { Empreendedorismo } \\
\text { social e a gestão social: } \\
\text { interfaces teóricas e } \\
\text { práticas em curso }\end{array}$ & $\begin{array}{l}\text { gestão dialógica, } \\
\text { transparente e } \\
\text { democrática }\end{array}$ & empreendedorismo social & & \\
\hline $\begin{array}{c}\text { Tecnologias sociais: } \\
\text { concepções, experiências } \\
\text { e impactos no contexto } \\
\text { brasileiro } \\
\end{array}$ & tecnologias sociais & & & \\
\hline
\end{tabular}




\begin{tabular}{|c|c|c|c|c|}
\hline $\begin{array}{l}\text { Sustentabilidade, } \\
\text { mercado e sociedade }\end{array}$ & sustentabilidade & $\begin{array}{l}\text { responsabilidade } \\
\text { socioambiental } \\
\text { corporativa }\end{array}$ & $\begin{array}{l}\text { modelos organizacionais } \\
\text { inovadores em termos de } \\
\text { inclusão social, } \\
\text { responsabilidade } \\
\text { socioambiental e } \\
\text { sustentabilidade }\end{array}$ & $\begin{array}{c}\text { contabilidade, relatórios, } \\
\text { balanços social e } \\
\text { ambiental }\end{array}$ \\
\hline $\begin{array}{l}\text { Responsabilidade social } \\
\text { corporativa política e } \\
\text { implicações para gestão } \\
\text { social }\end{array}$ & $\begin{array}{l}\text { responsabilidade social } \\
\text { corporativa }\end{array}$ & $\begin{array}{c}\text { influência e ação política } \\
\text { que os diferentes atores } \\
\text { organizacionais exercem } \\
\text { sobre o espaço de ação } \\
\text { pública }\end{array}$ & & \\
\hline $\begin{array}{l}\text { Trabalho, competências } \\
\text { e empoderamento: } \\
\text { refletindo sobre } \\
\text { cidadania na gestão } \\
\text { social } \\
\end{array}$ & $\begin{array}{l}\text { políticas públicas de } \\
\text { emprego e renda }\end{array}$ & trabalho e cidadania & $\begin{array}{l}\text { trabalho e } \\
\text { empoderamento }\end{array}$ & $\begin{array}{c}\text { relações de poder e } \\
\text { trabalho }\end{array}$ \\
\hline $\begin{array}{l}\text { Gestão social, trabalho e } \\
\text { dominação capitalista }\end{array}$ & gestão participativa & $\begin{array}{c}\text { gestão verde, ambiental } \\
\text { ou ecológica }\end{array}$ & alternativa ao capitalismo & \\
\hline \multicolumn{5}{|c|}{ Eixo 3: Gestão Social, Políticas Públicas, Desenvolvimento e Relações Estado-Sociedade } \\
\hline Grupos de Trabalho & \multicolumn{4}{|l|}{ Temas Chave } \\
\hline $\begin{array}{l}\text { Movimentos sociais, } \\
\text { democracia e gestão } \\
\text { social }\end{array}$ & movimentos sociais & $\begin{array}{l}\text { formas organizacionais } \\
\text { da sociedade civil }\end{array}$ & $\begin{array}{c}\text { ampliação da esfera } \\
\text { pública e de suas } \\
\text { dimensões } \\
\text { organizacionais }\end{array}$ & ação coletiva \\
\hline $\begin{array}{c}\text { Juventudes e } \\
\text { participação política }\end{array}$ & $\begin{array}{c}\text { juventude e sua relação } \\
\text { com a política }\end{array}$ & & & \\
\hline $\begin{array}{c}\text { Modelos de proteção } \\
\text { social e políticas sociais } \\
\text { no campo da seguridade } \\
\text { social brasileira }\end{array}$ & proteção social & $\begin{array}{l}\text { modelos de proteção } \\
\text { social }\end{array}$ & $\begin{array}{c}\text { políticas sociais de Saúde, } \\
\text { Previdência e Assistência } \\
\text { Social. }\end{array}$ & \\
\hline \multirow[t]{2}{*}{$\begin{array}{l}\text { Tendências no campo de } \\
\text { públicas }\end{array}$} & $\begin{array}{l}\text { participação, controle } \\
\text { social e cidadania }\end{array}$ & $\begin{array}{c}\text { relações } \\
\text { intergovernamentais }\end{array}$ & $\begin{array}{c}\text { monitoramento e } \\
\text { avaliação de políticas } \\
\text { públicas }\end{array}$ & $\begin{array}{c}\text { planejamento } \\
\text { governamental, } \\
\text { governança e } \\
\text { governabilidade }\end{array}$ \\
\hline & gestão pública & modelos cooperativos & gestão de pessoas & $\begin{array}{l}\text { capacidade e execução } \\
\text { orçamentária e financeira }\end{array}$ \\
\hline $\begin{array}{c}\text { Gestão social e } \\
\text { governança territorial e } \\
\text { ambiental em contextos } \\
\text { locais ou regionais }\end{array}$ & $\begin{array}{l}\text { desenvolvimento } \\
\text { territorial }\end{array}$ & $\begin{array}{l}\text { gestão e governança } \\
\text { social e ambiental }\end{array}$ & parceria & \\
\hline $\begin{array}{c}\text { Gestão social do } \\
\text { desenvolvimento: a } \\
\text { perspectiva do território }\end{array}$ & arranjos produtivos locais & conselhos gestores & & \\
\hline $\begin{array}{l}\text { Estado como indutor do } \\
\text { desenvolvimento e ação } \\
\text { pública: espaços de } \\
\text { diálogo, decisão e ação }\end{array}$ & $\begin{array}{l}\text { redefinição do próprio } \\
\text { papel do Estado }\end{array}$ & compras públicas & $\begin{array}{l}\text { Estado como indutor de } \\
\text { desenvolvimento }\end{array}$ & $\begin{array}{c}\text { novos espaços de diálogo } \\
\text { e governança }\end{array}$ \\
\hline
\end{tabular}

Enapegs 2010

\begin{tabular}{|c|c|c|c|c|}
\hline Temática & \multicolumn{2}{|l|}{ Temas Chave } \\
\hline $\begin{array}{c}\text { Ensino e Pesquisa em } \\
\text { Gestão Social }\end{array}$ & $\begin{array}{c}\text { desafios da formação em } \\
\text { gestão social }\end{array}$ & $\begin{array}{c}\text { capacidades e perfis de } \\
\text { competências especificas } \\
\text { do gestor social }\end{array}$ & $\begin{array}{c}\text { ensino e pesquisa em } \\
\text { gestão social }\end{array}$ & \\
\hline $\begin{array}{c}\text { Diversidade, } \\
\text { Movimentos Sociais e } \\
\text { Ações Afirmativas }\end{array}$ & $\begin{array}{c}\text { discutir o emprego do } \\
\text { gênero e da raça como } \\
\text { construtores de } \\
\text { identidades sociais }\end{array}$ & democracia racial & ações afirmativas & $\begin{array}{c}\text { políticas públicas } \\
\text { relacionadas aos } \\
\text { portadores de } \\
\text { necessidades especiais }\end{array}$ \\
\hline
\end{tabular}




\begin{tabular}{|c|c|c|c|c|}
\hline \multicolumn{2}{|c|}{ Temas de Interesse } & Temas Chave \\
\hline $\begin{array}{c}\text { Relações entre Estado e } \\
\text { Sociedade }\end{array}$ & $\begin{array}{c}\text { coprodução de bens } \\
\text { públicos }\end{array}$ & governo aberto & $\begin{array}{c}\text { relações entre Estado e } \\
\text { organizações do terceiro } \\
\text { setor }\end{array}$ & $\begin{array}{c}\text { controle social } \\
\text { Interfaces entre Gestão } \\
\text { Pública e Gestão Social }\end{array}$ \\
\hline
\end{tabular}

Dicionário para a Formação em Gestão

Social: verbete "Gestão Social"

\begin{tabular}{|c|c|c|c|c|}
\hline \multicolumn{5}{|l|}{ Temas Chave } \\
\hline $\begin{array}{c}\text { gestão de organizações } \\
\text { do terceiro setor }\end{array}$ & $\begin{array}{l}\text { tomada de decisão } \\
\text { coletiva, sem coerção, } \\
\text { baseada na } \\
\text { inteligibilidade da } \\
\text { linguagem, na } \\
\text { dialogicidade e no } \\
\text { entendimento esclarecido } \\
\text { como processo, na } \\
\text { transparência como } \\
\text { pressuposto e na } \\
\text { emancipação enquanto } \\
\text { fim último. }\end{array}$ & $\begin{array}{c}\text { participação e } \\
\text { dialogicidade }\end{array}$ & $\begin{array}{l}\text { horizontalidade nas } \\
\text { relações de poder }\end{array}$ & $\begin{array}{c}\text { valores de democracia, } \\
\text { participação, justiça, } \\
\text { equidade e bem-estar } \\
\text { social; a dialogicidade, } \\
\text { horizontalidade e } \\
\text { solidariedades nas } \\
\text { relações; a atuação } \\
\text { intersetorial e } \\
\text { interorganizacional. }\end{array}$ \\
\hline
\end{tabular}

Fonte: Elaborado pela autora

\subsubsection{Procedimentos de análise dos dados}

A etapa seguinte à definição e coleta das bases de dados foi a extração das informações que seriam utilizadas na análise dos resultados. Nesta fase foram coletados: ano de publicação, evento/periódico, título do artigo e autores. Assim como Guarido Filho (2008), constatamos formas variadas de registro de um mesmo autor, o que nos obrigou a realizar a padronização das informações. Sempre que eram constatadas formas diferentes de registro ou grafia de um único autor, adotava-se uma forma única para dar unidade nas entradas do banco de dados. Os dados coletados foram consolidados em planilhas eletrônicas no software Microsoft Excel 2010. A segunda etapa, que consiste na modelagem das redes sociais e cálculo das medidas de centralidade, foi realizada por meio do software Node XL.

A análise dos dados foi segmentada em quatro momentos, seguindo a proposta de Guarido Filho (2008):

i. Distribuição da produção científica do campo da Gestão Social;

ii. Classificação dos pesquisadores, segundo sua regularidade de produção científica; 
iii. Caracterização do campo da Gestão Social em relação à produtividade e cooperação entre os pesquisadores; e

iv. Configuração da estrutura de colaboração, em termos de agrupamento, centralidade dos atores e características estruturais da rede.

Para o primeiro item foram calculados os seguintes indicadores bibliométricos da produção científica: volume de artigos, volume de autores e volume de autorias ${ }^{5}$ por ano e por evento/periódico. Também foram calculados os autores mais prolíficos, através da contagem do número de artigos por autor.

Em relação ao segundo item, foi utilizada uma classificação baseada na regularidade de sua atuação, considerando sua produção científica (GUARIDO FILHO, 2008). Tal classificação foi baseada em critérios utilizados por Guarido Filho (2008), os quais foram fruto de uma adaptação de um estudo anterior feito por Braun, Glanzel e Schubert (2001). Os critérios de classificação podem ser verificados no quadro 8 .

\section{Quadro 8: Classificação dos autores (conceito)}

\begin{tabular}{ll}
\hline \multicolumn{1}{c}{ Categoria } & \multicolumn{1}{c}{ Descrição } \\
\hline Continuantes & $\begin{array}{l}\text { Mais de uma publicação em } 5 \text { ou mais anos diferentes e ao menos uma nos últimos } 3 \\
\text { anos }\end{array}$ \\
\hline Transientes & $\begin{array}{l}\text { Mais de uma publicação distribuídas ao longo do período em não mais do que } 4 \text { anos } \\
\text { diferentes, sendo ao menos uma nos últimos } 3 \text { anos e ao menos uma em anos anteriores }\end{array}$ \\
One-timers & Apenas uma única publicação em todo o período analisado. \\
Entrantes & $\begin{array}{l}\text { Mais de uma publicação em um ou mais anos diferentes nos últimos três anos } \\
\text { (exclusivamente) }\end{array}$ \\
Retirantes & $\begin{array}{l}\text { Mais de uma publicação em um ou mais anos diferentes, mas sem publicações nos } \\
\text { últimos 3 anos }\end{array}$ \\
\hline
\end{tabular}

Fonte: Guarido Filho (2008) adaptado de Braun, Glanzel e Schubert (2001)

O terceiro item também segue critérios utilizados por Guarido Filho (2008) com base no estudo realizado por Braun, Glanzel e Schubert (2001). O objetivo é criar indicadores que reflitam a produtividade e cooperação no campo da Gestão Social. Os conceitos de cada indicador podem ser vistos no quadro 9.

\footnotetext{
${ }^{5}$ Para fins desta pesquisa, consideramos autoria como a soma do número total de autores por artigo.
} 
Quadro 9: Indicadores de produtividade e colaboração

\begin{tabular}{ll}
\hline \multicolumn{1}{c}{ Indicador } & Conceito \\
\hline Artigos & número de artigos publicados/apresentados nos eventos e periódicos \\
\hline Autores & o número de autores em cada evento e periódico \\
Autorias & soma do número de autores por artigo \\
Colaboração & a divisão do número de autorias pelo número de artigos \\
Produtividade fracionada & a divisão número de artigos pelo número de autores \\
\hline Produtividade total & a divisão do número de autorias pelo número de autores \\
\hline
\end{tabular}

Fonte: Guarido Filho (2008) adaptado de Braun, Glanzel e Schubert (2001)

Segundo Guarido Filho (2008), o valor da produtividade total indica o envolvimento dos autores em pesquisas e trabalhos e a produtividade fracionada remete a produtividade média de cada autor relativamente ao número total de artigos publicados/apresentados. De acordo Lee e Bozeman (2005) apud Guarido Filho (2008), “a produtividade fracionada avalia o modo como o crescimento da produção se divide diante do número de pesquisadores no campo, eliminando o viés de superestimação que poderia surgir da análise do valor bruto de produção".

Por fim, para aferir a estrutura de colaboração da rede foi necessário estruturar a base de dados em duplas de autores, conforme a figura 2.

Figura 2: Modelo de estruturação da base de dados

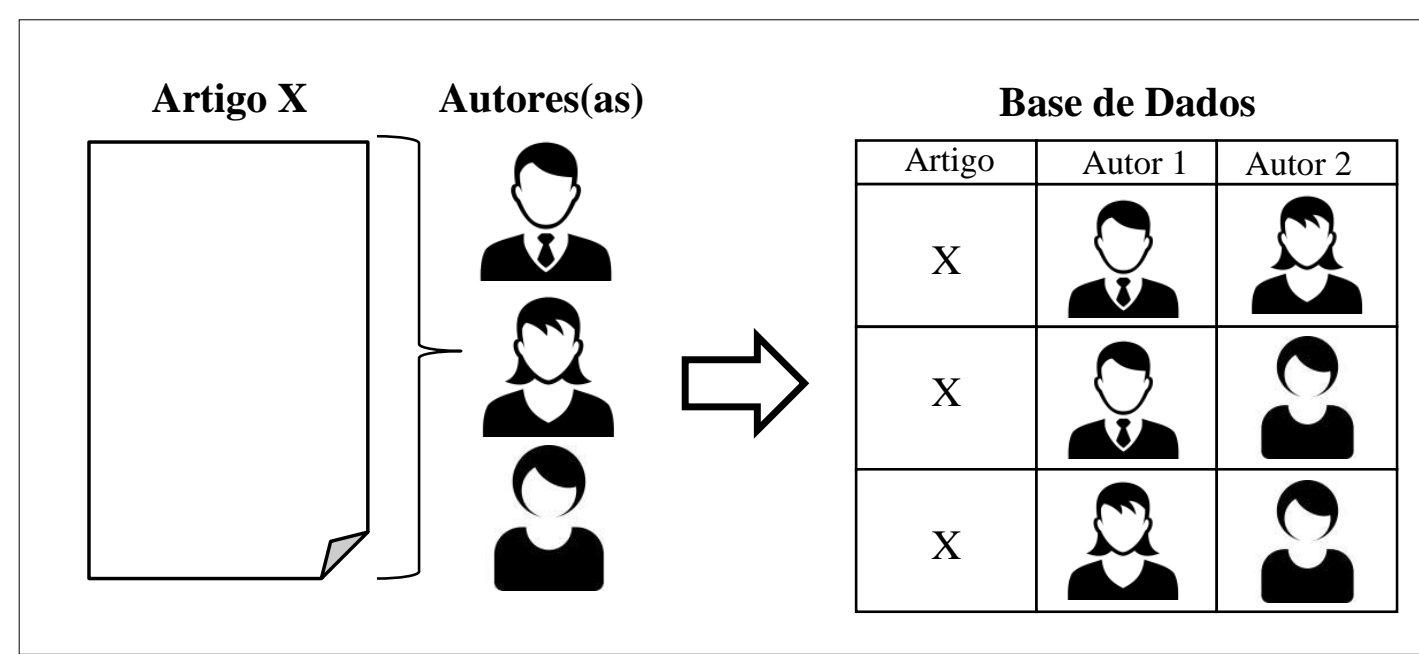

Fonte: elaborado pela autora 
As bases de dados foram estruturadas de duas formas: uma consolidada com todos os eventos e periódicos e uma segmentada por evento/periódico. Essa escolha foi feita para que pudéssemos ter uma análise geral sobre a Rede de Pesquisadores de Gestão Social (RPGS) e uma análise setorizada que permitisse a verificação de especificidades de cada evento e periódico.

Nesta fase foram aferidas três medidas de centralidade: de grau (degree centrality), de intermediação (betweenness centrality) e de autovetor (eigenvector centrality). As medidas de centralidade identificam os vértices mais importantes de cada rede. De acordo com Wasserman e Faust (1994), a centralidade de grau (degree centrality) pode ser definida como o número de ligações de um vértice. Segundo Guarido Filho (2008), "trata-se do número de relacionamento de co-autoria que um pesquisador possui, de modo que quanto maior o grau, maior será sua vizinhança direta, tornando-o mais visível diante de sua capacidade de interagir com os demais". Wasserman e Faust (1994) alertam que a centralidade de grau (degree centrality) depende do tamanho do tamanho do grupo $g$ e, portanto, o maior valor poderá ser $g-1$. Dessa forma, eles propõem a normalização da variável por meio da seguinte fórmula:

$$
C^{\prime}{ }_{D}\left(n_{i}\right)=\frac{d\left(n_{i}\right)}{g-1}
$$

Já a centralidade de intermediação (betweenness centrality) quantifica o número de vezes em que um vértice atua como uma ponte ao longo do caminho mais curto entre outros dois nós. Segundo Wasserman e Faust (1994), a interação entre dois atores não adjacentes depende de um rol de outros atores, principalmente aqueles que estão no meio do caminho entre os dois. Esses "outros atores" possuem, potencialmente, algum controle sobre as interações dos atores não adjacentes. Assim como para a centralidade de grau (degree centrality), Wasserman e Faust (1994) também propõem uma fórmula para a normalização da centralidade de intermediação (betweenness centrality):

$$
C^{\prime}{ }_{B}\left(n_{i}\right)=C^{\prime}{ }_{B}\left(n_{i}\right) /\left[\frac{(g-1)(g-2)}{2}\right]
$$

Por fim, a centralidade de autovetor (eigenvector centrality) pode ser conceituada como a influência de um vetor na rede. Ou seja, essa medida não considera apenas o número de laços (grau/degree) que um vértice possui, mas também o número de laços (grau/degree) dos vértices a que ele está conectado. 
Para os pesquisadores que se destacaram por obterem as maiores medidas de centralidade ou foram classificados como os pesquisadores mais prolíficos da rede foram coletadas também informações sobre sua formação acadêmica (última titulação, instituição, área e subárea) e sobre sua vinculação institucional (vínculo e instituição). A pesquisa e coleta dos dados foram feitas na Plataforma Lattes. O objetivo dessa etapa foi investigar mais a fundo a configuração da rede, representada pelos pesquisadores mais relevantes de cada uma delas. Para Wasserman e Faust (1994), esse tipo de informação é denominado de variável de composição, a qual pode ser definida como a medida dos atributos do ator. 


\section{ANÁLISE DOS RESULTADOS}

\subsection{Rede de Pesquisadores de Gestão Social (RPGS)}

Para fins desta pesquisa, considerou-se como a "Rede de Pesquisadores de Gestão Social (RPGS)" o conjunto de pesquisadores que publicaram artigos ou apresentaram trabalhos nos seguintes eventos e periódicos durante o período de 2005 a 2015, conforme mostra o quadro 7.

\section{Quadro 10: Eventos e periódicos analisados no estudo}

\section{Eventos}

Colóquio Internacional sobre o Poder Local

EMAPEGS - Encontro Mineiro de Administração Pública, Economia Solidária e Gestão Social

EnANPAD - Encontro da Associação Nacional de Pós-Graduação e Pesquisa em Administração

ENAPEGS - Encontro Nacional de Pesquisadores em Gestão Social

EnAPG - Encontro de Administração Pública e Governança da Associação Nacional de Pós-Graduação e Pesquisa em Administração

\section{Periódicos}

Administração Pública e Gestão Social (APGS)

Cadernos de Gestão Pública e Cidadania (CGP\&C)

Cadernos de Gestão Social (CGS)

Cadernos EBAPE.BR

NAU Social

Revista de Administração Pública (RAP)

Revista Interdisciplinar de Gestão Social (RIGS)

Revista Organizações \& Sociedade (O\&S)

Fonte: elaborado pela autora

Durante o período analisado, constatou-se que a "Rede de Pesquisadores de Gestão Social (RPGS)" é composta por 4.302 pesquisadores distintos e possui um total de 3.257 artigos publicados e/ou apresentados. 
Dos eventos analisados, deve-se destacar que apenas o EnANPAD teve edições anuais durante o período considerado nesta pesquisa. Na sequência, podemos apontar o ENAPEGS, que teve 8 edições (2007 a 2014), o EnAPG, com 5 edições (2006, 2008, 2010, 2012 e 2014), o Colóquio Internacional sobre o Poder Local, com 3 edições (2006, 2009 e 2012), e embora o EMAPEGS tenha tido 5 edições $(2009$, 2010, 2012, 2013 e 2015), para fins desta pesquisa, analisamos apenas os trabalhos apresentados na edição de 2015, quando este evento passou a ter abrangência nacional. Isto se deve ao fato de que, na edição de 2014 do ENAPEGS, evento específico da "Rede de Pesquisadores de Gestão Social (RPGS)", deliberou-se que o Encontro passaria a ocorrer de dois em dois anos e não mais anualmente. Desta forma, o EMAPEGS adquiriu o status de único evento específico da área de Gestão Social em 2015.

Em termos de volume de trabalhos apresentados durante o período analisado (2005 a 2015), destacamos o EnANPAD, com 803 trabalhos (32\%), o ENAPEGS, com 745 trabalhos (29\%), e, curiosamente, o Colóquio Internacional sobre o Poder Local, que, embora tenha tido apenas 3 edições analisadas, contou com 698 trabalhos (28\%).

Em relação aos periódicos, quatro possuem edições em todo o período analisado (2005 a 2015). São eles: Cadernos EBAPE.BR, Cadernos de Gestão Pública e Cidadania, Revista de Administração Pública (RAP) e Revista Organizações \& Sociedade (O\&S). Logo em seguida vem Administração Pública e Gestão Social (APGS), com publicações em 7 anos (2009 a 2015), a NAU Social, com publicações em 6 anos diferentes (2010 a 2015), o Cadernos de Gestão Social, com edições nos anos de 2007, 2009, 2012, 2013 e 2014. Por fim, a Revista Interdisciplinar de Gestão Social (RIGS), com publicações entre os anos de 2012 e 2014.

Analisando o número de artigos publicados, destaca-se a NAU Social, com 156 artigos (21\%), embora suas publicações tenham ocorrido apenas em 6 anos, dos 11 anos analisados. Posteriormente, ressalta-se o número de publicações da Revista de Administração Pública (RAP), com 137 artigos (19\%), os Cadernos EBAPE.BR, com 93 artigos (13\%), e a Revista Interdisciplinar de Gestão Social (RIGS), com 89 artigos (12\%). 
Tabela 1: Volume de artigos na "Rede de Pesquisadores de Gestão Social (RPGS)" por ano

\begin{tabular}{|c|c|c|c|c|c|c|c|c|c|c|c|c|c|}
\hline & 2005 & 2006 & 2007 & 2008 & 2009 & 2010 & 2011 & 2012 & 2013 & 2014 & 2015 & Total & $\%$ \\
\hline Evento & 50 & 405 & 81 & 122 & 348 & 224 & 152 & 455 & 211 & 276 & 197 & 2.521 & $77 \%$ \\
\hline EnANPAD & 50 & 54 & 68 & 58 & 47 & 78 & 89 & 89 & 90 & 77 & 103 & 803 & $32 \%$ \\
\hline ENAPEGS & & & 13 & 21 & 61 & 109 & 63 & 187 & 121 & 170 & & 745 & $30 \%$ \\
\hline Colóq. Poder Local & & 308 & & & 240 & & & 150 & & & & 698 & $28 \%$ \\
\hline EnAPG & & 43 & & 43 & & 37 & & 29 & & 29 & & 181 & $7 \%$ \\
\hline EMAPEGS & & & & & & & & & & & 94 & 94 & $4 \%$ \\
\hline Periódico & 34 & 25 & 36 & 34 & 43 & 58 & 79 & 144 & 122 & 106 & 55 & 736 & $23 \%$ \\
\hline NAU Social & & & & & & 15 & 30 & 39 & 29 & 22 & 21 & 156 & $21 \%$ \\
\hline RAP & 20 & 9 & 6 & 8 & 7 & 7 & 9 & 19 & 16 & 18 & 18 & 137 & $19 \%$ \\
\hline Cadernos EBAPE.BR & 9 & 4 & 12 & 7 & 7 & 8 & 17 & 11 & 8 & 7 & 3 & 93 & $13 \%$ \\
\hline RIGS & & & & & & & & 34 & 30 & 25 & & 89 & $12 \%$ \\
\hline CGS & & & 12 & & 11 & & & 19 & 20 & 10 & & 72 & $10 \%$ \\
\hline O\&S & 1 & 9 & 3 & 16 & 7 & 8 & 7 & 3 & 5 & 5 & 5 & 69 & $9 \%$ \\
\hline APGS & & & & & 7 & 11 & 11 & 9 & 8 & 12 & 6 & 64 & $9 \%$ \\
\hline CGP\&C & 4 & 3 & 3 & 3 & 4 & 9 & 5 & 10 & 6 & 7 & 2 & 56 & $8 \%$ \\
\hline Total & 84 & 430 & 117 & 156 & 391 & 282 & 231 & 599 & 333 & 382 & 252 & 3.257 & $100 \%$ \\
\hline
\end{tabular}

Fonte: elaborado pela autora

Considerando os dados acima expostos, constatamos que os eventos possuem uma importância significativa para a "Rede de Pesquisadores de Gestão Social (RPGS)", pois concentra $77 \%$ dos trabalhos apresentados/publicados no campo da Gestão Social. Ainda em relação ao volume de trabalhos apresentados, deve-se ressaltar que houve um pico no ano de 2012, que pode ser explicado pela realização do ENAPEGS, que contou com 187 artigos (o maior volume de todos os ENAPEGS já realizados), e do Colóquio Internacional sobre o Poder Local, com 150 artigos. Apenas esses dois eventos já somam 56\% dos artigos apresentados/publicados no ano de 2012. Também é importante dizer que apenas nos anos de 2012, 2013 e 2014 houve publicação de todos os periódicos analisados, sendo que o ano de 2012 foi o ano que teve o maior número de artigos publicados, atingindo a marca de 144 publicações. Já em 2015, notamos uma queda no número de artigos, pois não houve as realizações do ENAPEGS, do Colóquio Internacional sobre o Poder Local e do EnAPG. Em relação aos periódicos, notamos uma queda no número de artigos em relação ao ano de 2014 
nas seguintes revistas: Administração Pública e Gestão Social (APGS), Cadernos EBAPE.BR e Cadernos de Gestão Pública e Cidadania. Além disso, não houve edição de duas revistas: Revista Interdisciplinar de Gestão Social (RIGS) e Cadernos de Gestão Social (CGS).

\section{Gráfico 1: Evolução do volume de artigos na "Rede de Pesquisadores de Gestão Social (RPGS)"}

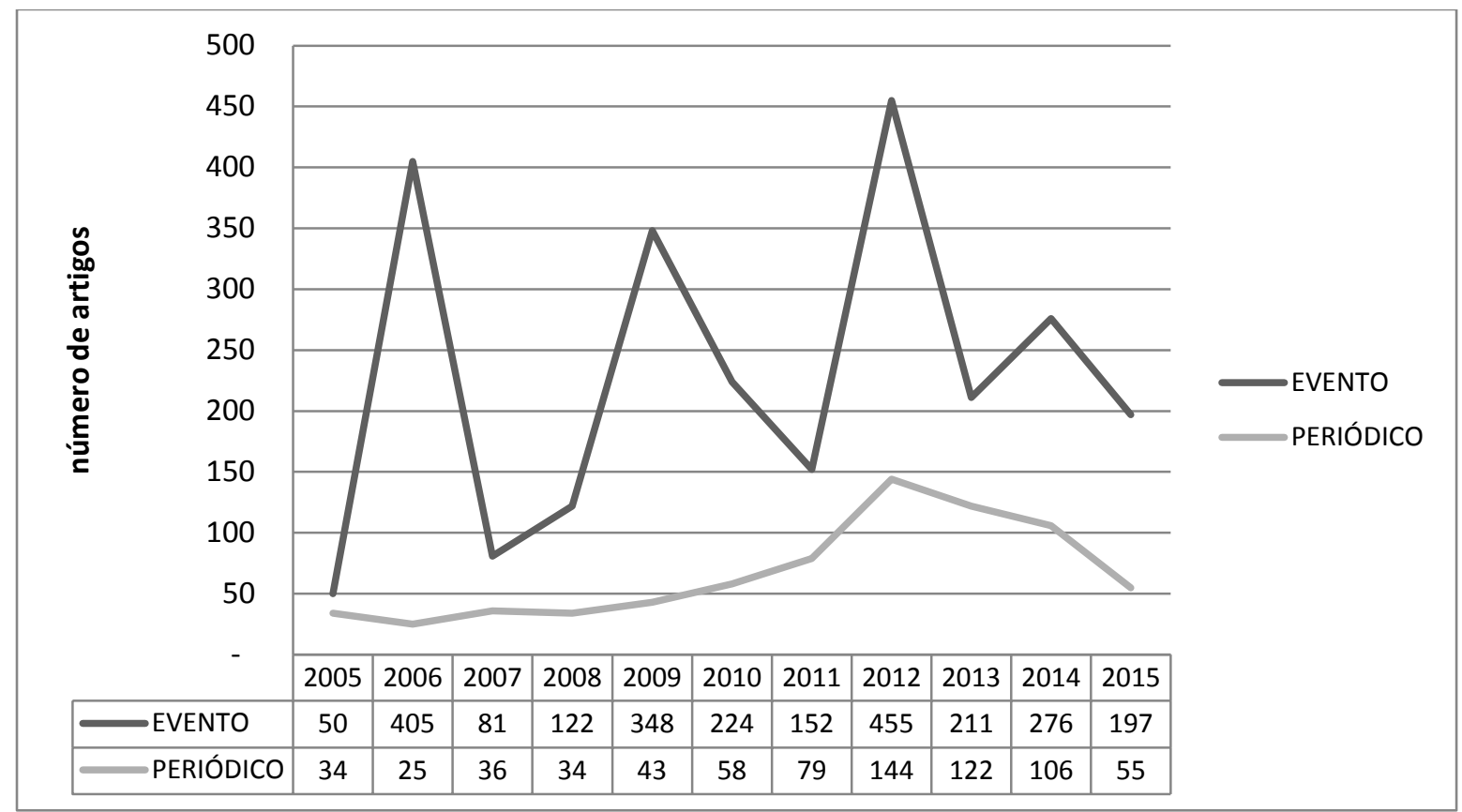

Fonte: elaborado pela autora

A evolução do número de pesquisadores da "Rede de Pesquisadores de Gestão Social (RPGS)" acompanha a tendência do número de artigos publicados/apresentados ano a ano. Novamente, notamos os picos nos anos de realização do Colóquio Internacional sobre o Poder Local, o qual contou com 528, 472 e 313 pesquisadores nas edições de 2006, 2009 e 2012, respectivamente. Ainda que o número de pesquisadores presentes no ENAPEGS tenha contribuído para que o ano de 2012 fosse o ano com o maior número de pesquisadores (1.259) na "Rede de Pesquisadores de Gestão Social (RPGS)", não foi o ano em que o ENAPEGS concentrou o maior volume de pesquisadores. Essa marca foi batida no evento de 2014, o qual congregou 354 pesquisadores. Outro ponto que podemos destacar é que os eventos não concentram apenas o maior número de artigos publicados/apresentados comparados aos periódicos, mas também o maior número de pesquisadores, mantendo inclusive o percentual de $77 \%$. Podemos verificar esses dados no gráfico 2, logo abaixo. 
Gráfico 2: Evolução do número de pesquisadores na "Rede de Pesquisadores de Gestão Social (RPGS)"

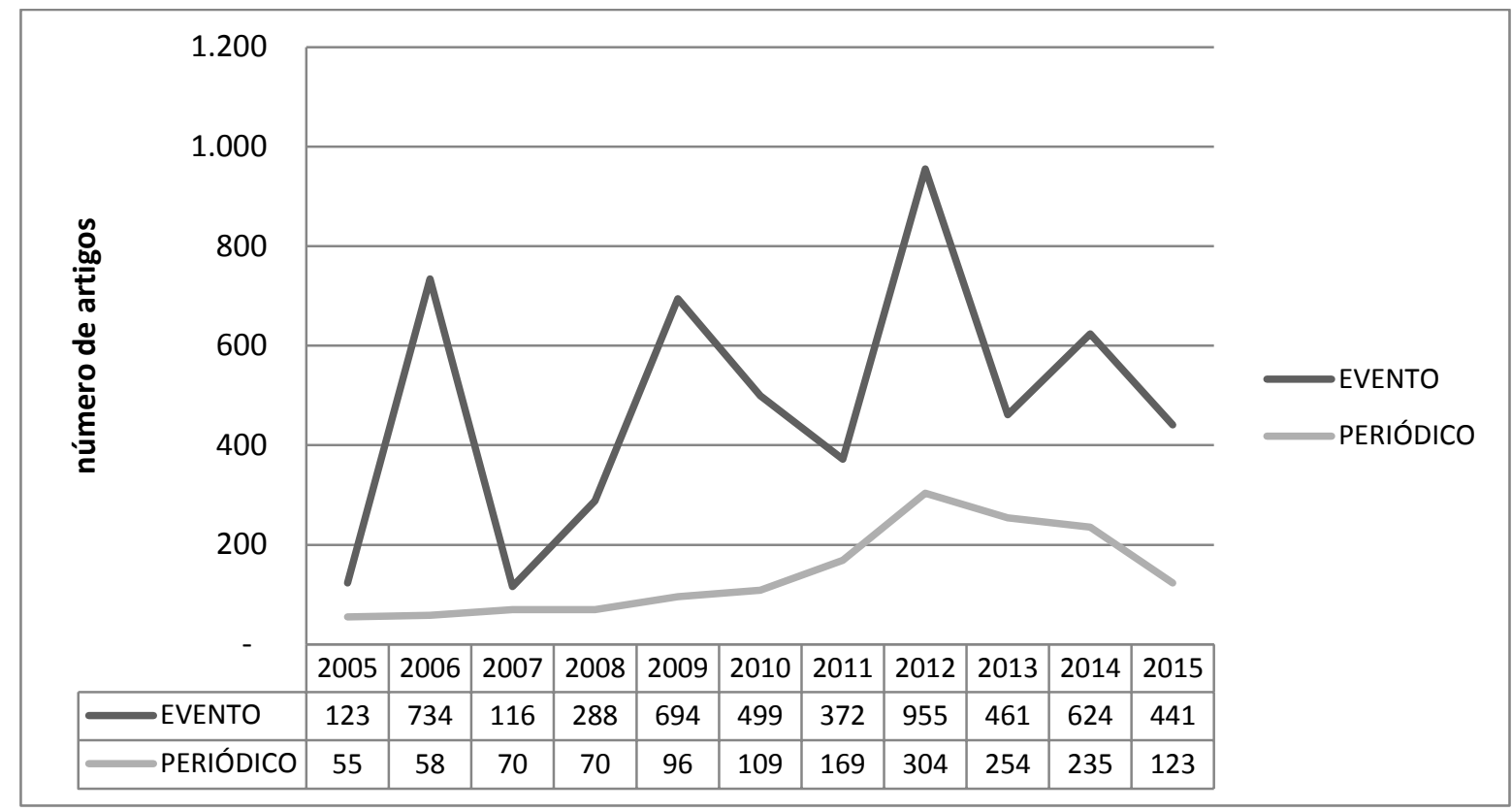

Fonte: elaborado pela autora

Outra dimensão que é possível analisar refere-se à colaboração e a produtividade da "Rede de Pesquisadores de Gestão Social (RPGS)".

Tabela 2: Índices da "Rede de Pesquisadores de Gestão Social (RPGS)"

\begin{tabular}{ccccccc}
\hline ANO & ARTIGOS & AUTORES & AUTORIAS & $\begin{array}{c}\text { COLABO- } \\
\text { RAÇÃO }\end{array}$ & $\begin{array}{c}\text { PRODUTI- } \\
\text { VIDADE } \\
\text { (fracionada) } \\
(\boldsymbol{A} / \boldsymbol{B})\end{array}$ & $\begin{array}{c}\text { PRODUTI- } \\
\text { VIDADE } \\
(\text { total) } \\
(\boldsymbol{C} / \boldsymbol{B})\end{array}$ \\
\hline $\mathbf{2 0 0 5}$ & 84 & 178 & 179 & 2,13 & 0,47 & 1,01 \\
$\mathbf{2 0 0 6}$ & 430 & 792 & 901 & 2,10 & 0,54 & 1,14 \\
$\mathbf{2 0 0 7}$ & 117 & 186 & 226 & 1,93 & 0,63 & 1,22 \\
$\mathbf{2 0 0 8}$ & 156 & 358 & 376 & 2,41 & 0,44 & 1,05 \\
$\mathbf{2 0 0 9}$ & 391 & 790 & 943 & 2,41 & 0,49 & 1,19 \\
$\mathbf{2 0 1 0}$ & 282 & 608 & 682 & 2,42 & 0,46 & 1,12 \\
$\mathbf{2 0 1 1}$ & 231 & 541 & 584 & 2,53 & 0,43 & 1,08 \\
$\mathbf{2 0 1 2}$ & 599 & 1.259 & 1.413 & 2,36 & 0,48 & 1,12 \\
$\mathbf{2 0 1 3}$ & 333 & 715 & 790 & 2,37 & 0,47 & 1,10 \\
$\mathbf{2 0 1 4}$ & 382 & 859 & 958 & 2,51 & 0,44 & 1,12 \\
$\mathbf{2 0 1 5}$ & 252 & 564 & 615 & 2,44 & 0,45 & 1,09 \\
TOTAL & $\mathbf{3 . 2 5 7}$ & $\mathbf{6 . 8 5 0}$ & $\mathbf{7 . 6 6 7}$ & $\mathbf{2 , 3 5}$ & $\mathbf{0 , 4 8}$ & $\mathbf{1 , 1 2}$ \\
\hline
\end{tabular}


Ao analisar a tabela, verificamos que a média geral de colaboração da "Rede de Pesquisadores de Gestão Social (RPGS)" é de 2,35 autores por artigo, atingindo seu ápice em 2011, com o índice de 2,53 autores por artigo, e seu valor mais baixo, de apenas 1,93 autores por artigo, no ano de 2007. Pode-se comparar esse índice com os valores calculados em trabalhos análogos a este, como é o caso de Silva (2012), que tratou da "Rede de Pesquisadores de Administração Pública", e Trottmann (2012), que abordou a "Rede de Pesquisadores de Políticas Públicas". Segundo Silva (2012), o índice de colaboração da "Rede de Pesquisadores de Administração Pública" é de 2,14 autores por artigo, e Trottmann (2012) aponta que o índice de colaboração da "Rede de Pesquisadores de Políticas Públicas" é de 1,94 autores por artigo. Desta forma, podemos verificar que, dos campos do saber que compõem o Campo de Públicas, a Gestão Social apresentou maior índice de colaboração. Ao passo que, se focarmos a análise no índice de produtividade fracionada, ou seja, a divisão do número de artigos pelo número de autores, constatamos que a Gestão Social apresenta o menor índice, a saber, 0,48 artigos por autor. Já no campo da Administração Pública este índice é de 0,64 (SILVA, 2002) e no campo de Políticas Públicas chega a 0,66 artigos por autor (TROTTMANN, 2012).

\section{Gráfico 3: Colaboração e Produtividade da "Rede de Pesquisadores de Gestão Social (RPGS)"}

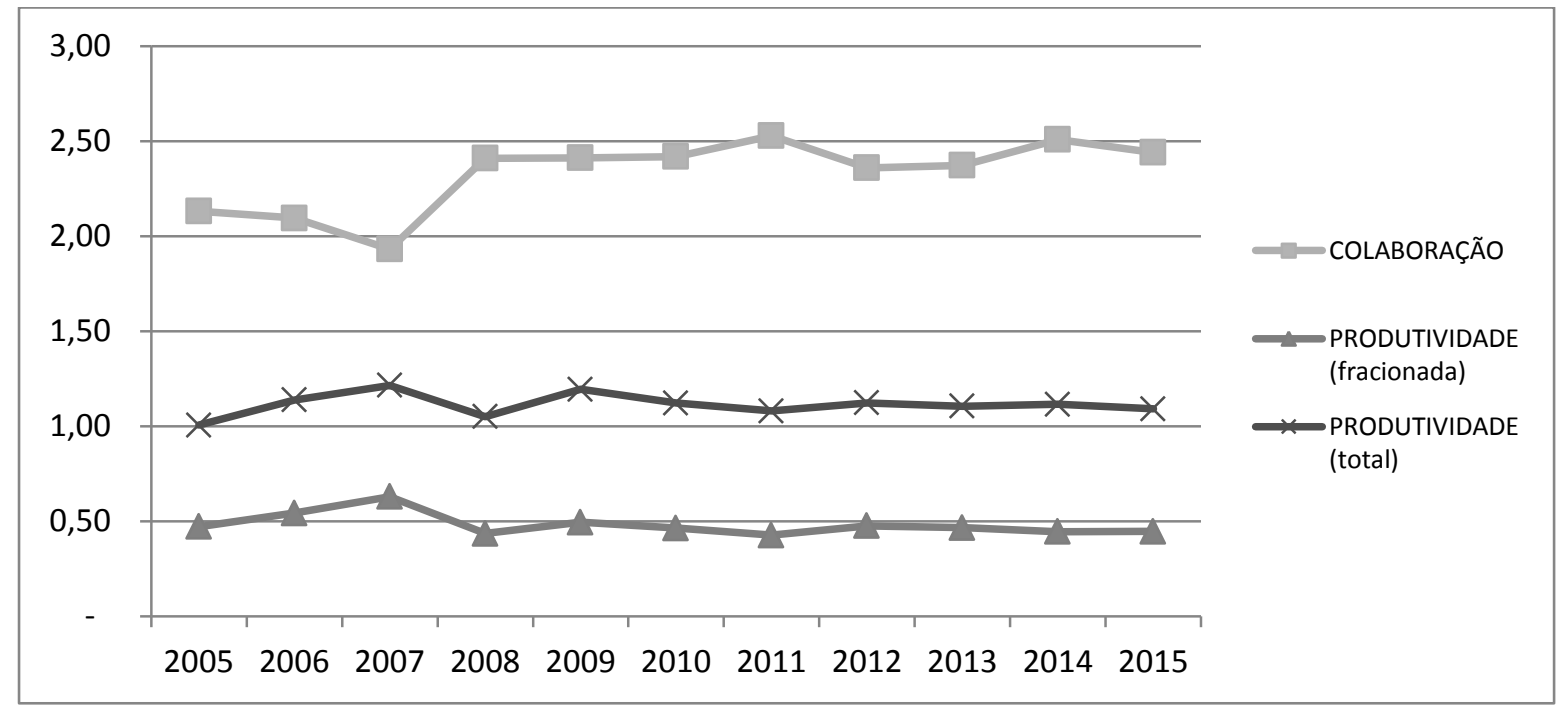

Fonte: elaborado pela autora

Outro dado que corrobora os índices de colaboração acima apresentado é a análise do número de autores por artigo na "Rede de Pesquisadores de Gestão Social (RPGS)". Nota-se 
que $37,89 \%$ (1.234) dos artigos analisados possuem 2 autores por artigo, seguidos de $26,65 \%$ (803) dos artigos, com apenas 1 autor. Ainda que a "Rede de Pesquisadores de Gestão Social (RPGS)" apresente o maior índice de colaboração entre as redes de pesquisadores do Campo de Públicas, conforme exposto acima, nota-se que os artigos de produção individual representam uma fatia significativa do total de artigos publicados no campo. As demais distribuições do número de autores por artigo podem ser vistas no gráfico 4 .

\section{Gráfico 4: Número de autores por artigo}

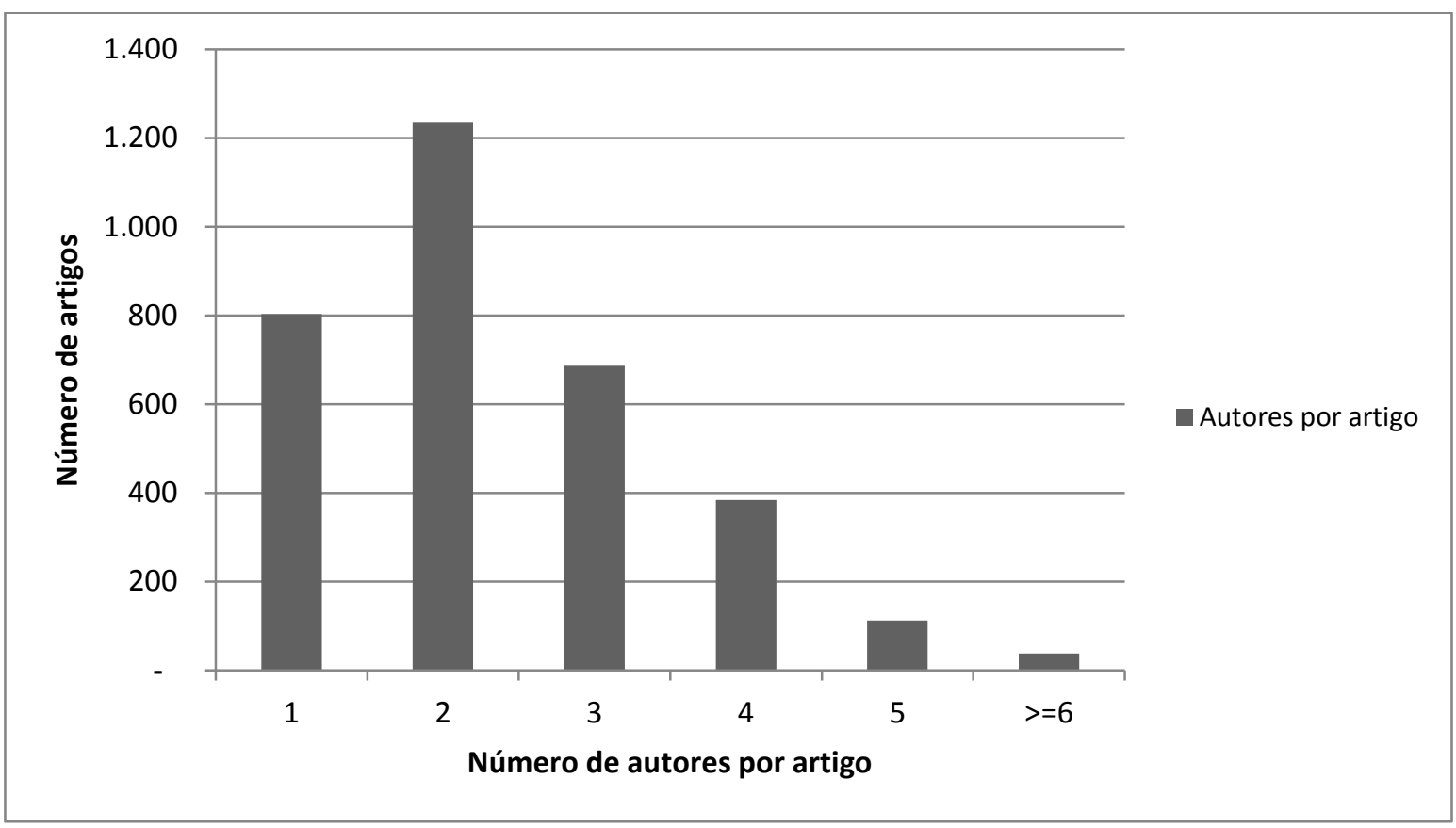

Fonte: elaborado pela autora

O presente estudou também investigou os pesquisadores da "Rede de Pesquisadores de Gestão Social (RPGS)" utilizando uma classificação baseada na regularidade de sua atuação, considerando sua produção científica (GUARIDO FILHO, 2008).

Considerando a classificação proposta por Guarido Filho (2008), notamos que 72,11\% dos pesquisadores da "Rede de Pesquisadores de Gestão Social (RPGS)" tiveram uma única publicação em todo o período analisado, ou seja, foram classificados como one-timers. Posteriormente, temos que $12,62 \%$ dos pesquisadores foram classificados como retirantes, ou seja, sem publicação nos últimos três anos do período analisado. Logo na sequência, podemos apontar que $9,14 \%$ dos pesquisadores são transientes, os quais apresentam certa regularidade em suas publicações, inclusive em período recente. Após, temos os entrantes, representando 
$3,49 \%$ do número de pesquisadores da área, o que assinala que poucos novos pesquisadores entraram no campo da Gestão Social nos últimos três anos. Por fim, com apenas 2,65\%, há os pesquisadores continuantes, que possuem publicações em cinco ou mais anos diferentes, considerando o período recente dos últimos três anos.

\section{Tabela 3: Classificação dos pesquisadores da "Rede de Pesquisadores de Gestão Social (RPGS)"}

\begin{tabular}{ccc}
\hline Categoria & $\mathbf{N}^{\mathbf{0}}$ de Pesquisadores & $\begin{array}{c}\text { \% do total de } \\
\text { pesquisadores da rede }\end{array}$ \\
\hline Continuantes & 114 & $2,65 \%$ \\
Transientes & 393 & $9,14 \%$ \\
One-timers & 3.102 & $72,11 \%$ \\
Entrantes & 150 & $3,49 \%$ \\
Retirantes & 543 & $12,62 \%$ \\
TOTAL & 4.302 & $100,0 \%$ \\
\hline
\end{tabular}

Fonte: elaborado pela autora

Assim como no campo da Gestão Social, Trottmann (2012) encontrou uma configuração muito semelhante no campo de Políticas Públicas, pois a classificação encontrada foi: $74,97 \%$ de one-timers, $10,02 \%$ de retirantes, $9,88 \%$ de transientes, $3,59 \%$ de entrantes e apenas 1,54\% de continuantes. Esse cenário alterou-se quando Silva (2012) aplicou a mesma classificação sobre a "Rede de Pesquisadores de Administração Pública", pois, ao contrário dos campos de Gestão Social e Políticas Públicas, o campo da Administração Pública apresentou uma porcentagem de entrantes superior à porcentagem de transientes, a saber: $71,54 \%$ de one-timers, $11,13 \%$ de retirantes, $8,61 \%$ de entrantes, $6,55 \%$ de transientes, e 2,17\% de continuantes. Devemos destacar também que, dos três campos, o da Gestão Social é o que apresenta o maior percentual de pesquisadores continuantes, o que talvez possa ser explicado pela existência da Rede de Pesquisadores de Gestão Social (RGS), que tem sido permanente e crescente na última década. 
Tabela 4: Comparação entre a classificação dos pesquisadores dos campos de Gestão Social, Políticas Públicas e Administração Pública

\begin{tabular}{cccc}
\hline Categoria & Gestão Social & Políticas Públicas & $\begin{array}{c}\text { Administração } \\
\text { Pública }\end{array}$ \\
\hline Continuantes & $2,65 \%$ & $1,54 \%$ & $2,17 \%$ \\
Transientes & $9,14 \%$ & $9,88 \%$ & $6,55 \%$ \\
One-timers & $72,11 \%$ & $74,97 \%$ & $71,54 \%$ \\
Entrantes & $3,49 \%$ & $3,59 \%$ & $8,61 \%$ \\
Retirantes & $12,62 \%$ & $10,02 \%$ & $11,13 \%$ \\
\hline
\end{tabular}

Fonte: elaborado pela autora com base em Silva (2012) e Trottmann (2012)

Ainda em relação à classificação dos autores, podemos notar que, embora, os autores continuantes representem a menor parcela da "Rede de Pesquisadores de Gestão Social (RPGS)" (apenas 2,65\%), eles são responsáveis pela produção de 18,35\% artigos do total analisado neste estudo, o que significa uma produtividade total (divisão de artigos por autor) de aproximadamente 12 artigos por autor. Se analisarmos a produtividade das demais categorias, vemos que a produtividade (total) dos autores continuantes é cerca de 4 vezes maior do que a produtividade dos autores transientes, por exemplo, que é de aproximadamente 3 artigos por autor. Outras informações que podemos extrair da tabela 5 é a proporção de artigos com e sem coautoria por categoria de autor. Notamos que a categoria dos one-timers é a que mais produziu artigos sem coautoria $(12,02 \%)$, ao passo que a categoria dos transientes é a que apresentou maior número de artigos com coautoria, chegando a $91,61 \%$ do total da produção da categoria.

Tabela 5: Volume e padrão de produção científica por categoria de autor

\begin{tabular}{lccccc}
\hline & Continuante & Transiente & One-timer & Entrante & Retirante \\
\hline Autores & $2,65 \%$ & $9,14 \%$ & $72,11 \%$ & $3,49 \%$ & $12,62 \%$ \\
Autorias em artigos & $18,35 \%$ & $16,94 \%$ & $40,46 \%$ & $4,43 \%$ & $19,81 \%$ \\
Produtividade (total) & 12,34 & 3,31 & 1,00 & 2,27 & 2,80 \\
Artigos com coautoria & $89,62 \%$ & $91,61 \%$ & $87,98 \%$ & $90,59 \%$ & $90,59 \%$ \\
Artigos sem coautoria & $10,38 \%$ & $8,39 \%$ & $12,02 \%$ & $9,41 \%$ & $9,41 \%$ \\
\hline \multicolumn{7}{c}{ Fonte: elaborado pela autora }
\end{tabular}

Da tabela 5, podemos focar as publicações com coautoria apenas dos pesquisadores continuantes. Neste caso, observamos que, dos artigos publicados pelos continuantes, $28,15 \%$ 
deles foram em parceria com algum pesquisador one-timer. Esse fenômeno também foi verificado por Silva (2012) em sua análise da "Rede de Pesquisadores de Administração Pública", em que 30,47\% da produção dos pesquisadores continuantes foram elaboradas em parceria com pesquisadores one-timers. No entanto, na "Rede de Pesquisadores de Gestão Social (RPGS)”, os percentuais de colaboração dos continuantes com outras categorias segue a seguinte ordem: one-timers, com 28,15\%, transientes, com 25,09\%, retirantes, com 22,72\%, continuantes, com 17,91\%, e entrantes, com 6,13\%. Na "Rede de Pesquisadores de Administração Pública", Silva (2012) observou as seguintes porcentagens: one-timers, com $30,47 \%$, continuantes, com $23,36 \%$, retirantes, com $20,99 \%$, entrantes, com $15,15 \%$, e transientes, com 10,04\%. Vale ressaltar que, nesta análise, consideramos as coautorias entre categorias de maneira não exclusiva, ou seja, um único artigo pode ter sido escrito por duas ou mais categorias. Este fato explica também porque o número total de artigos da tabela 6 não corresponde ao número exato de publicações de autores continuantes. Na tabela 6 , um único artigo pode ter sido contabilizado mais de uma vez.

Tabela 6: Relação entre pesquisadores continuantes e outros pesquisadores (publicações não exclusivas)

\begin{tabular}{lccccc}
\hline & Continuante & Transiente & One-timer & Entrante & Retirante \\
\hline $\mathbf{N}^{\mathbf{0}}$ de artigos & 257 & 360 & 404 & 88 & 326 \\
\% do total & $17,91 \%$ & $25,09 \%$ & $28,15 \%$ & $6,13 \%$ & $22,72 \%$ \\
\hline & Fonte: elaborado pela autora
\end{tabular}

No entanto, podemos analisar a relação entre as categorias utilizando outro critério: os artigos publicados exclusivamente entre a categoria de continuantes e outra categoria. Dessa forma, constatamos que os autores continuantes mantêm maior número de parcerias com os autores one-timers $(27,94 \%)$. O que se altera em relação à análise anterior é a porcentagem entre continuantes e transientes, que cai de $25,09 \%$ para $19,91 \%$, entre continuantes e entrantes, que cai de $6,13 \%$ para $5,03 \%$, e as porcentagens de continuantes e retirantes, que sobem de $17,91 \%$ e $22,72 \%$, respectivamente, para $23,55 \%$. 
Tabela 7: Relação entre pesquisadores continuantes e outros pesquisadores (publicações exclusivas)

\begin{tabular}{lccccc}
\hline & Continuante & Transiente & One-timer & Entrante & Retirante \\
\hline $\mathbf{N}^{\mathbf{0}}$ de artigos & 220 & 186 & 261 & 47 & 220 \\
\% do total & $23,55 \%$ & $19,91 \%$ & $27,94 \%$ & $5,03 \%$ & $23,55 \%$ \\
\hline \multicolumn{5}{c}{ Fonte: elaborado pela autora }
\end{tabular}

Dos dados coletados na pesquisa, também foi possível extrair quais são os pesquisadores mais prolíficos da "Rede de Pesquisadores de Gestão Social (RPGS)", ou seja, quais são os pesquisadores com o maior número de publicações. Desta forma, selecionamos os dez maiores valores do indicador de publicações, chegando aos resultados expostos na tabela 8 .

Tabela 8: Os dez autores mais prolíficos da "Rede de Pesquisadores de Gestão Social (RPGS)"6

\begin{tabular}{lcc}
\hline \multicolumn{1}{c}{ Autor(a) } & $\mathbf{N}^{\mathbf{0}}$ publicações & Categoria \\
\hline JOSÉ ROBERTO PEREIRA & 49 & continuante \\
AIRTON CARDOSO CANÇADO & 32 & continuante \\
MARCO AURÉLIO MARQUES FERREIRA & 32 & continuante \\
LUCIANO ANTONIO PRATES JUNQUEIRA & 28 & continuante \\
ARIÁDNE SCALFONI RIGO & 27 & continuante \\
ARMINDO DOS SANTOS DE SOUSA TEODÓSIO & 26 & continuante \\
ROSINHA DA SILVA MACHADO CARRION & 26 & continuante \\
ANA PAULA PAES DE PAULA & 23 & continuante \\
LAMOUNIER ERTHAL VILLELA & 23 & continuante \\
WASHINGTON JOSÉ DE SOUZA & 23 & continuante \\
\hline
\end{tabular}

Fonte: elaborado pela autora

Ainda considerando a classificação dos pesquisadores, devemos apontar que os 10 pesquisadores mais prolíficos da rede foram classificados como continuantes, ou seja, suas produções são regulares e atuais. Na figura 3, pode-se observar a configuração da "Rede de Pesquisadores de Gestão Social (RPGS)", marcada pelo alto número de pesquisadores e ligações entre eles, sendo que os pontos em destaque são os autores mais prolíficos.

\footnotetext{
${ }^{6}$ Foi adotado o critério de apontar os 10 autores mais prolíficos como padrão, mas todos os demais pesquisadores classificados como continuantes constarão no anexo.
} 
Figura 3: "Rede de Pesquisadores de Gestão Social (RPGS)" com os autores mais prolíficos em destaque

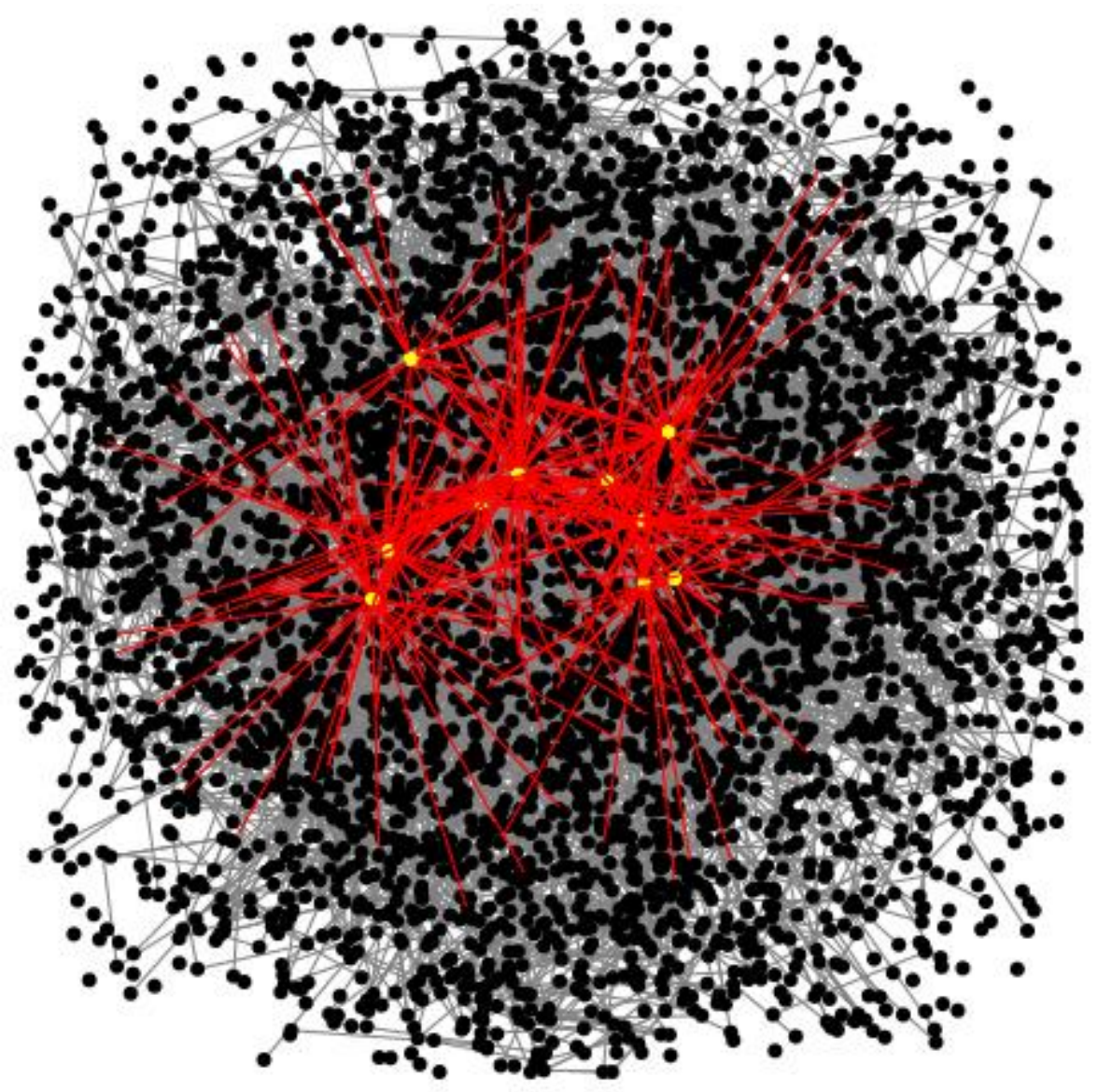

Fonte: elaborado pela autora

O autor mais prolífico "Rede de Pesquisadores de Gestão Social (RPGS)" é José Roberto Pereira, com 49 publicações. Considerando o período analisado (2005-2015), o autor possui publicações em nove dos onze anos analisados. Já em relação à distribuição da sua produção, destacamos que ele apresentou trabalhos em todos os eventos analisados e publicou artigos em seis dos oito periódicos considerados neste estudo. 
Quadro 11: Atributos dos autores mais prolíficos da "Rede de Pesquisadores de Gestão Social (RPGS)"

\begin{tabular}{|c|c|c|c|c|c|c|}
\hline \multirow[b]{2}{*}{ Pesquisador(a) } & \multicolumn{4}{|c|}{ Formação acadêmica } & \multicolumn{2}{|c|}{ Atuação profissional } \\
\hline & $\begin{array}{l}\text { Última } \\
\text { titulação }\end{array}$ & Instituição & Área & Subárea & $\begin{array}{c}\text { Vínculo } \\
\text { Institucional }\end{array}$ & Instituição \\
\hline $\begin{array}{l}\text { AIRTON CARDOSO } \\
\text { CANÇADO }\end{array}$ & Doutorado & UFLA & Administração & & Professor & UFT \\
\hline $\begin{array}{l}\text { ANA PAULA PAES DE } \\
\text { PAULA }\end{array}$ & Doutorado & UNICAMP & Administração & $\begin{array}{l}\text { Administração } \\
\text { Pública }\end{array}$ & Professora & UFMG \\
\hline $\begin{array}{l}\text { ARIÁDNE SCALFONI } \\
\text { RIGO }\end{array}$ & Doutorado & UFBA & Administração & & Professora & UFBA \\
\hline $\begin{array}{l}\text { ARMINDO DOS SANTOS } \\
\text { DE SOUSA TEODÓSIO }\end{array}$ & Doutorado & FGV/SP & Administração & $\begin{array}{c}\text { Administração de } \\
\text { Empresas / } \\
\text { Administração } \\
\text { Pública } \\
\end{array}$ & Professor & PUC/MG \\
\hline $\begin{array}{l}\text { JOSÉ ROBERTO } \\
\text { PEREIRA }\end{array}$ & Doutorado & UnB & Sociologia & $\begin{array}{l}\text { Sociologia Rural / } \\
\text { Sociologia do } \\
\text { Desenvolvimento }\end{array}$ & Professor & UFLA \\
\hline $\begin{array}{l}\text { LAMOUNIER ERTHAL } \\
\text { VILLELA }\end{array}$ & Doutorado & $\begin{array}{c}\text { Université } \\
\text { Sorbonne } \\
\text { Nouvelle - } \\
\text { Paris } 3\end{array}$ & Economia & $\begin{array}{c}\text { Crescimento, } \\
\text { Flutuações e } \\
\text { Planejamento } \\
\text { Econômico / } \\
\text { Economia do Bem- } \\
\text { Estar Social } \\
\end{array}$ & Professor & UFRRJ \\
\hline $\begin{array}{l}\text { LUCIANO ANTONIO } \\
\text { PRATES JUNQUEIRA }\end{array}$ & Doutorado & USP & Administração & $\begin{array}{l}\text { Administração } \\
\text { Pública }\end{array}$ & Professor & PUC/SP \\
\hline $\begin{array}{l}\text { MARCO AURÉLIO } \\
\text { MARQUES FERREIRA }\end{array}$ & Doutorado & UFV & Administração & $\begin{array}{c}\text { Administração de } \\
\text { Setores Específicos } \\
\text { / Métodos } \\
\text { Quantitativos } \\
\text { Aplicados às } \\
\text { Ciências Sociais } \\
\end{array}$ & Professor & UFV \\
\hline $\begin{array}{l}\text { ROSINHA DA SILVA } \\
\text { MACHADO CARRION }\end{array}$ & Doutorado & UFRGS & $\begin{array}{c}\text { Sociologia / } \\
\text { Administração }\end{array}$ & $\begin{array}{c}\text { Sociologia do } \\
\text { Trabalho / } \\
\text { Administração de } \\
\text { Empresas }\end{array}$ & Professora & UFRGS \\
\hline $\begin{array}{l}\text { WASHINGTON JOSÉ DE } \\
\text { SOUZA }\end{array}$ & Doutorado & UFC & Educação & & Professor & UFRN \\
\hline
\end{tabular}

Fonte: elaborado pela autora com base na Plataforma Lattes/2016

Com o objetivo de investigar com mais detalhes a "Rede de Pesquisadores de Gestão Social (RPGS)", buscaram-se informações sobre formação acadêmica e atuação profissional dos autores mais prolíficos, conforme o quadro 10. Notamos que cinco dos dez autores mais prolíficos, ou possuem formação acadêmica ou atuam profissionalmente em alguma universidade do estado de Minas Gerais (Universidade Federal de Lavras, Universidade 
Federal de Viçosa, Pontifícia Universidade Católica de Minas Gerais e Universidade Federal de Minas Gerais). Inclusive, a Universidade Federal de Lavras e a Universidade Federal de Viçosa têm se revezado na organização do EMAPEGS - Encontro Mineiro de Administração Pública, Economia Solidária e Gestão Social. Além disso, a Universidade Federal de Lavras sediou o ENAPEGS - Encontro Nacional de Pesquisadores em Gestão Social em 2010 e a Pontifícia Universidade Católica de Minas Gerais acolheu a Reunião da Rede de Pesquisadores de Gestão Social (RGS) - RGS, em 2015. Desta forma, podemos constatar que as universidades mineiras têm exercido um papel de destaque no campo científico da Gestão Social no Brasil nos últimos anos, assim como a UFBA, a FGV-RJ e a PUC-SP tiveram um papel de lançamento do campo no país, conforme verificamos na seção 2.1.1 Principais definições em torno do termo Gestão Social.

Outra medida que podemos extrair da análise da "Rede de Pesquisadores de Gestão Social (RPGS)" é a centralidade de grau (degree centrality), que, conforme exposto no capítulo de procedimentos metodológicos, reflete o número de laços que o ator tem com outros atores da rede. Neste caso, novamente o pesquisador José Roberto Pereira é o autor com maior centralidade de grau (0,01093), o que representa 47 laços na rede. Na sequência, os autores apresentam as seguintes medidas de centralidade de grau: Marco Aurélio Marques Ferreira, com 0,00930 (40 laços), Armindo dos Santos de Sousa Teodósio, com 0,00814 (35 laços), Magnus Luiz Emmendoerfer, com 0,00767 (33 laços), e Luciano Antonio Prates Junqueira, com 0,00721 (31 laços).

Tabela 9: Centralidade de grau (degree) da "Rede de Pesquisadores de Gestão Social (RPGS)"

\begin{tabular}{lc}
\hline \multicolumn{1}{c}{ Pesquisador } & $\begin{array}{c}\text { Centralidade de } \\
\text { grau }\end{array}$ \\
\hline JOSÉ ROBERTO PEREIRA & 0,01093 \\
MARCO AURÉLIO MARQUES FERREIRA & 0,00930 \\
ARMINDO DOS SANTOS DE SOUSA TEODÓSIO & 0,00814 \\
MAGNUS LUIZ EMMENDOERFER & 0,00767 \\
LUCIANO ANTONIO PRATES JUNQUEIRA & 0,00721 \\
\hline \multicolumn{2}{c}{ Fonte: elaborado pela autora }
\end{tabular}

$\mathrm{Na}$ figura 4, podemos visualizar os autores que apresentaram maior centralidade de grau na rede e observar o número e o alcance de seus laços. 
Figura 4: Representação gráfica da centralidade de grau (degree) da "Rede de Pesquisadores de Gestão Social (RPGS)"

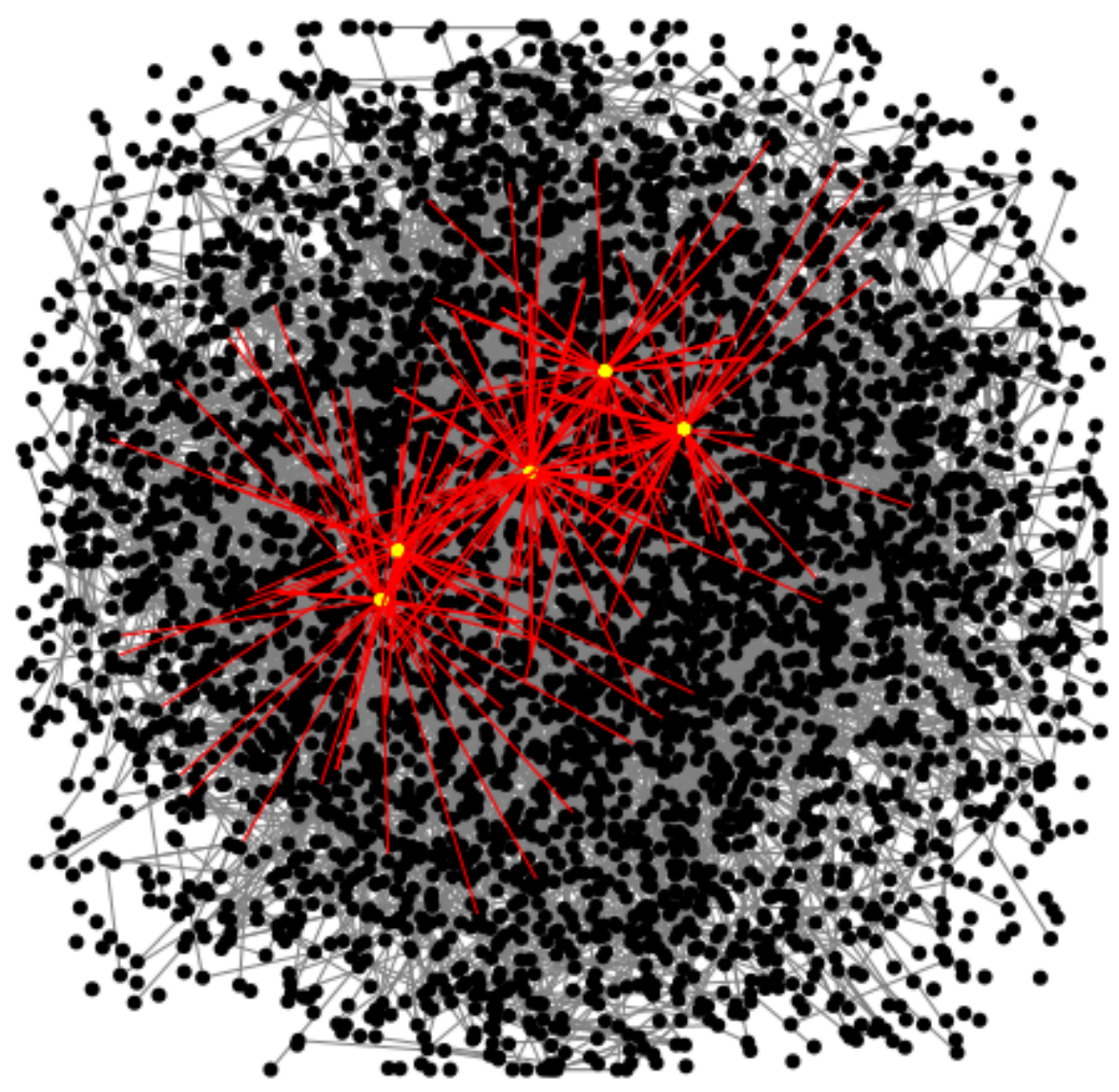

Fonte: elaborado pela autora

Quadro 12: Formação acadêmica e atuação profissional dos autores com maior centralidade de grau (degree) da "Rede de Pesquisadores de Gestão Social (RPGS)"

\begin{tabular}{|l|c|c|c|c|c|c|}
\hline \multirow{2}{*}{ Pesquisador(a) } & \multicolumn{3}{|c|}{ Formação acadêmica } & \multicolumn{2}{c|}{ Atuação profissional } \\
\cline { 2 - 6 } & $\begin{array}{c}\text { Última } \\
\text { titulação }\end{array}$ & Instituição & Área & Subárea & $\begin{array}{c}\text { Vínculo } \\
\text { Institucional }\end{array}$ & Instituição \\
\hline $\begin{array}{l}\text { ARMINDO DOS } \\
\text { SANTOS DE SOUSA } \\
\text { TEODÓSIO }\end{array}$ & Doutorado & FGV/SP & Administração & $\begin{array}{c}\text { Administração } \\
\text { de Empresas / } \\
\text { Administração } \\
\text { Pública }\end{array}$ & Professor & PUC/MG \\
\hline $\begin{array}{l}\text { JOSÉ ROBERTO } \\
\text { PEREIRA }\end{array}$ & Doutorado & UnB & Sociologia & $\begin{array}{c}\text { Sociologia Rural } \\
\text { / Sociologia do } \\
\text { Desenvolvimento }\end{array}$ & Professor & UFLA \\
\hline $\begin{array}{l}\text { LUCIANO ANTONIO } \\
\text { PRATES JUNQUEIRA }\end{array}$ & Doutorado & USP & Administração & $\begin{array}{c}\text { Administração } \\
\text { Pública }\end{array}$ & Professor & PUC/SP \\
\hline $\begin{array}{l}\text { MAGNUS LUIZ } \\
\text { EMMENDOERFER }\end{array}$ & Doutorado & UFMG & $\begin{array}{c}\text { Sociologia / } \\
\text { Administração }\end{array}$ & $\begin{array}{c}\text { Sociologia } \\
\text { Econômica e das } \\
\text { Organizaçóes / } \\
\text { Administração } \\
\text { de Empresas }\end{array}$ & Professor & UFV \\
\hline
\end{tabular}




\begin{tabular}{|c|c|c|c|c|c|c|}
\hline $\begin{array}{l}\text { MARCO AURÉLIO } \\
\text { MARQUES } \\
\text { FERREIRA }\end{array}$ & Doutorado & UFV & Administração & $\begin{array}{l}\text { Administração } \\
\text { de Setores } \\
\text { Específicos / } \\
\text { Métodos } \\
\text { Quantitativos } \\
\text { Aplicados às } \\
\text { Ciências Sociais }\end{array}$ & Professor & UFV \\
\hline
\end{tabular}

Fonte: elaborado pela autora com base na Plataforma Lattes/2016

Quando analisamos os autores com maior centralidade de grau (degree), notamos que quatro dos cinco nomes aparecem também como autores mais prolíficos. A novidade neste quesito é o pesquisador Magnus Luiz Emmendoerfer. Em relação à formação acadêmica e atuação profissional, notamos novamente a preponderância das universidades mineiras, pois, dos cinco autores com maior centralidade de grau (degree), quatro deles possuem vínculo institucional com universidades do estado de Minas Gerais.

Além da centralidade de grau (degree centrality), podemos analisar a medida de centralidade de intermediação (betweenness centrality), que se refere ao poder de um dado ator da rede de intermediar a relação entre dois outros atores que ainda não possuem laços entre si. Novamente, o pesquisador que apresentou a maior medida foi José Roberto Pereira com 0,03456, seguido de Ariádne Scalfoni Rigo, com 0,03034, Fernando Guilherme Tenório, com 0,02936, e Magnus Luiz Emmendoerfer e Mário Aquino Alves, ambos com 0,02299.

Tabela 10: Centralidade de intermediação (betweeneess) da "Rede de Pesquisadores de Gestão Social (RPGS)"

\begin{tabular}{lc}
\hline \multicolumn{1}{c}{ Pesquisador } & $\begin{array}{c}\text { Centralidade de } \\
\text { intermediação }\end{array}$ \\
\hline JOSÉ ROBERTO PEREIRA & 0,03456 \\
ARIÁDNE SCALFONI RIGO & 0,03034 \\
FERNANDO GUILHERME TENÓRIO & 0,02936 \\
MAGNUS LUIZ EMMENDOERFER & 0,02300 \\
MÁRIO AQUINO ALVES & 0,02299 \\
\hline
\end{tabular}

Fonte: elaborado pela autora

$\mathrm{Na}$ figura 5, podemos observar os cinco pesquisadores com as maiores medidas de centralidade de intermediação (betweenness). 
Figura 5: Representação gráfica da centralidade de intermediação (betweenness) da "Rede de Pesquisadores de Gestão Social (RPGS)"

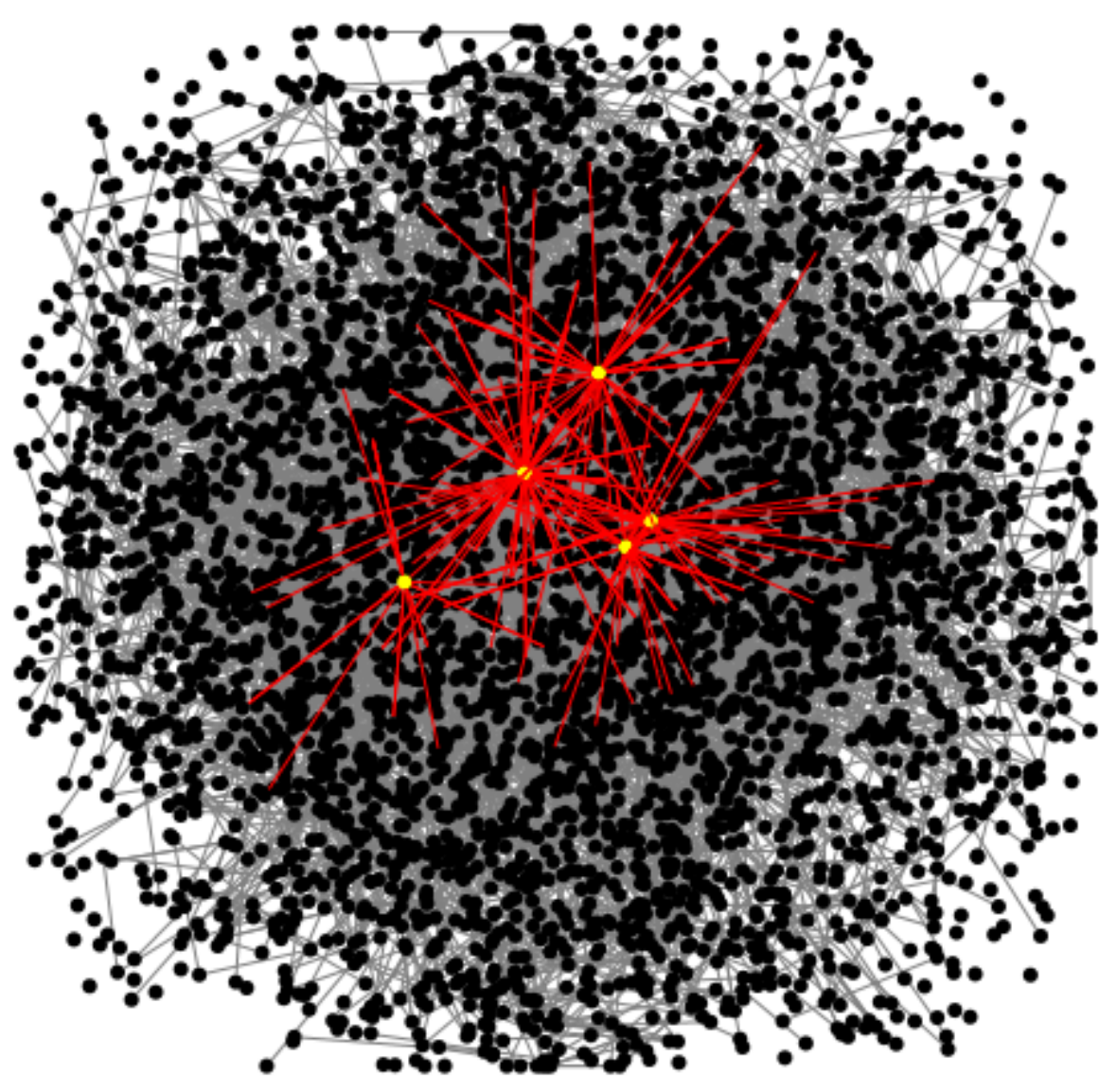

Fonte: elaborado pela autora

Quadro 13: Formação acadêmica e atuação profissional dos autores com maior centralidade de intermediação (betweenness) da "Rede de Pesquisadores de Gestão Social (RPGS)"

\begin{tabular}{|l|c|c|c|c|c|c|}
\hline \multirow{2}{*}{ Pesquisador(a) } & \multicolumn{3}{|c|}{ Formação acadêmica } & \multicolumn{2}{c|}{ Atuação profissional } \\
\cline { 2 - 6 } & $\begin{array}{c}\text { Última } \\
\text { titulação }\end{array}$ & Instituição & Área & Subárea & $\begin{array}{c}\text { Vínculo } \\
\text { Institucional }\end{array}$ & Instituição \\
\hline $\begin{array}{l}\text { ARIÁDNE SCALFONI } \\
\text { RIGO }\end{array}$ & Doutorado & UFBA & Administração & Professora & UFBA \\
\hline $\begin{array}{l}\text { FERNANDO } \\
\text { GUILHERME } \\
\text { TENÓRIO }\end{array}$ & Doutorado & UFRJ & $\begin{array}{c}\text { Engenharia de } \\
\text { Produção }\end{array}$ & Professor & FGV \\
\hline $\begin{array}{l}\text { JOSÉ ROBERTO } \\
\text { PEREIRA }\end{array}$ & Doutorado & UnB & Sociologia & $\begin{array}{l}\text { Sociologia Rural } \\
\text { / Sociologia do } \\
\text { Desenvolvimento }\end{array}$ & Professor & UFLA \\
\hline
\end{tabular}




\begin{tabular}{|l|l|l|l|c|c|c|}
\hline $\begin{array}{l}\text { MAGNUS LUIZ } \\
\text { EMMENDOERFER }\end{array}$ & Doutorado & UFMG & $\begin{array}{c}\text { Sociologia / } \\
\text { Administração } \\
\text { Econômica e das } \\
\text { Organizações / } \\
\text { Administração } \\
\text { de Empresas }\end{array}$ & Professor & UFV \\
\hline $\begin{array}{l}\text { MÁRIO AQUINO } \\
\text { ALVES }\end{array}$ & Doutorado & FGV/SP & Administração & $\begin{array}{c}\text { Administração } \\
\text { Pública }\end{array}$ & Professor & FGV/SP \\
\hline
\end{tabular}

Fonte: elaborado pela autora com base na Plataforma Lattes

Comparando os autores mais prolíficos com os autores que apresentaram maior centralidade de intermediação (betweenness), notamos a coincidência de apenas dois autores: José Roberto Pereira e Ariádne Scalfoni Rigo. O pesquisador Magnus Luiz Emmendoerfer, que aparece como um dos autores com maior centralidade de intermediação (betweenness), também consta na lista dos autores com maior centralidade de grau (degree). Os dois autores que não apareceram nas listas anteriores são Fernando Guilherme Tenório e Mário Aquino Alves, ambos com vínculo institucional com a Fundação Getúlio Vargas, embora de unidades distintas.

Por fim, a última medida que analisaremos na "Rede de Pesquisadores de Gestão Social (RPGS)" é a centralidade de autovetor (eigenvector), que mede a influência de um nó na rede.

Tabela 11: Centralidade de autovetor (eigenvector) da "Rede de Pesquisadores de Gestão Social (RPGS)"

\begin{tabular}{lc}
\hline Pesquisador & Autovetor \\
\hline MARCO AURÉLIO MARQUES FERREIRA & 0,000041 \\
MAGNUS LUIZ EMMENDOERFER & 0,000030 \\
AFONSO AUGUSTO TEIXEIRA DE FREITAS DE CARVALHO LIMA & 0,000025 \\
BRUNO TAVARES & 0,000023 \\
EDSON ARLINDO SILVA & 0,000023 \\
\hline
\end{tabular}

Fonte: elaborado pela autora

Ao contrário das demais medidas, o pesquisador que apresentou maior centralidade de autovetor (eigenvector) foi Marco Aurélio Marques Ferreira, com 0,000041. Na sequência, temos Magnus Luiz Emmendoerfer, com 0,000030, Afonso Augusto Teixeira de Freitas de Carvalho Lima, com 0,000025, e Bruno Tavares e Edson Arlindo Silva, ambos com 0,000023. A representação gráfica desta medida pode ser vista na figura 6 . 
Figura 6: Representação gráfica da centralidade de autovetor (eigenvector) da "Rede de Pesquisadores de Gestão Social (RPGS)"

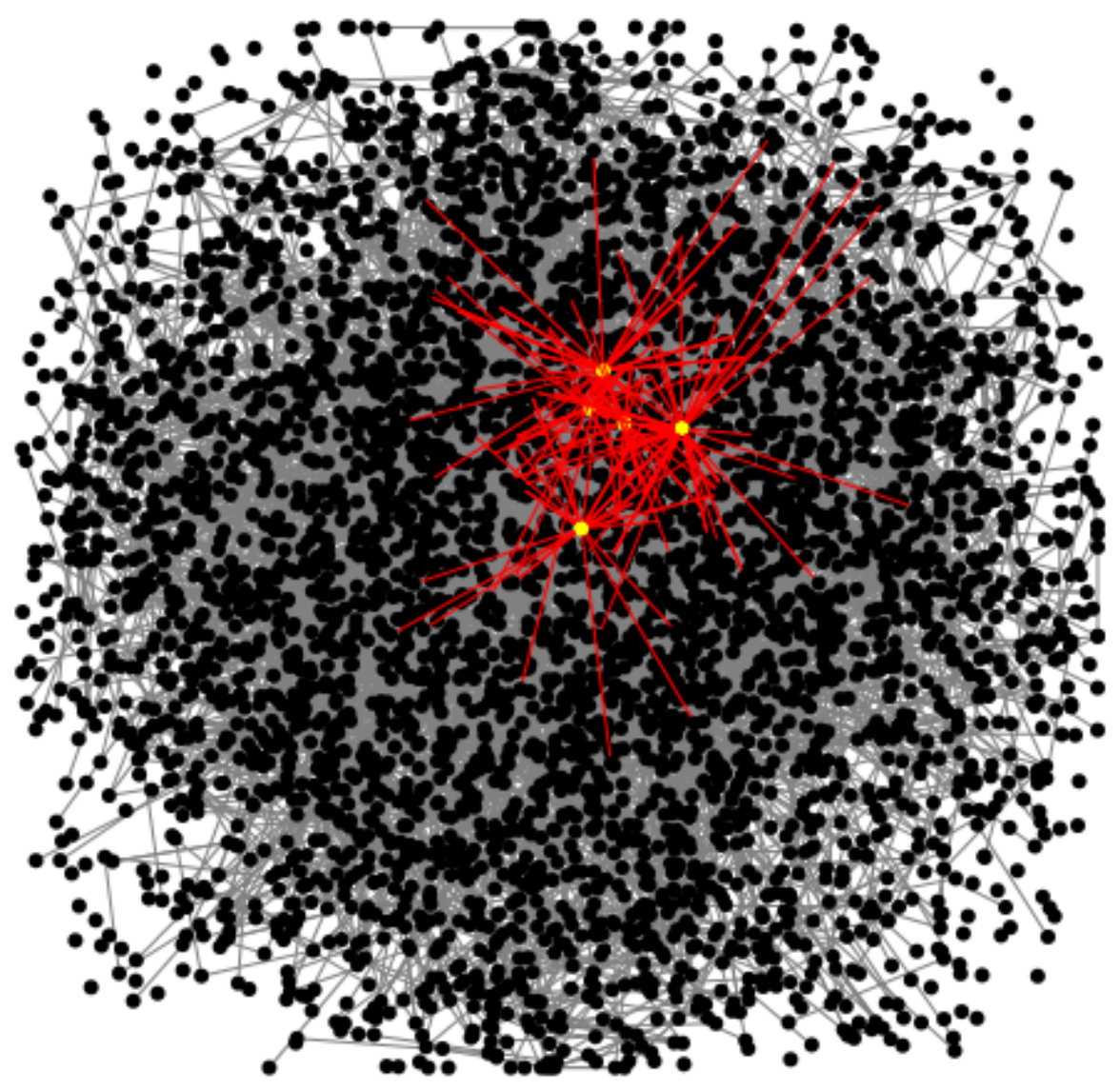

Fonte: elaborado pela autora

Quadro 14: Formação acadêmica e atuação profissional dos autores com maior centralidade de autovetor (eigenvector) da "Rede de Pesquisadores de Gestão Social (RPGS)"

\begin{tabular}{|l|c|c|c|c|c|c|}
\hline \multirow{2}{*}{ Pesquisador(a) } & \multicolumn{3}{|c|}{ Formação acadêmica } & \multicolumn{2}{c|}{ Atuação profissional } \\
\cline { 2 - 7 } & $\begin{array}{c}\text { Última } \\
\text { titulação }\end{array}$ & Instituição & Área & Subárea & \multicolumn{1}{c|}{$\begin{array}{c}\text { Vínculo } \\
\text { Institucional }\end{array}$} & Instituição \\
\hline $\begin{array}{l}\text { AFONSO AUGUSTO } \\
\text { TEIXEIRA DE } \\
\begin{array}{l}\text { FREITAS DE } \\
\text { CARVALHO LIMA }\end{array}\end{array}$ & Doutorado & UFSC & $\begin{array}{c}\text { Engenharia de } \\
\text { Produção }\end{array}$ & Professor & UFV \\
\hline $\begin{array}{l}\text { BRUNO TAVARES } \\
\text { EDSON ARLINDO } \\
\text { SILVA }\end{array}$ & Doutorado & UFLA & Administração & $\begin{array}{c}\text { Administração } \\
\text { de Empresas }\end{array}$ & Professor & UFV \\
\hline
\end{tabular}




\begin{tabular}{|l|l|l|l|c|l|c|}
\hline $\begin{array}{l}\text { MAGNUS LUIZ } \\
\text { EMMENDOERFER }\end{array}$ & Doutorado & UFMG & $\begin{array}{c}\text { Sociologia } \\
\text { Sociologia / } \\
\text { Administração } \\
\text { das } \\
\text { Organizaçães / } \\
\text { Administração } \\
\text { de Empreas }\end{array}$ & Professor & UFV \\
\hline $\begin{array}{l}\text { MARCO AURÉLIO } \\
\text { MARQUES FERREIRA }\end{array}$ & Doutorado & UFV & Administração & $\begin{array}{c}\text { Admistração } \\
\text { de Setores } \\
\text { Espećficos / } \\
\text { Métodos } \\
\text { Quantitativos } \\
\text { Aplicados às } \\
\text { Ciências Sociais }\end{array}$ & Professor & UFV \\
\hline
\end{tabular}

Fonte: elaborado pela autora com base na Plataforma Lattes

Neste caso, todos os autores possuem vínculo institucional com Universidade Federal de Viçosa e quatro dos cinco autores adquiriram titulação acadêmica em universidades mineiras, com destaque para a Universidade Federal de Lavras.

Embora tenhamos apontado que a Rede de Pesquisadores de Gestão Social (RPGS) é composta por 4.302 pesquisadores, deve-se ressaltar que são pesquisadores que publicaram na área, mas não, necessariamente, fazem parte do núcleo duro do campo. Os autores tradicionais e atuantes do campo da Gestão Social podem ser encontrados no Dicionário para a formação em Gestão Social (Boullosa, 2014). Ainda em relação aos autores tradicionais do campo, verificamos que nem todos figuraram as entre os pesquisadores com as maiores medidas calculadas, isso por que, os parâmetros utilizados consideram o volume de publicação de cada autor. Portanto, se um determinado autor possui um texto referência para o campo, mas não mantém um alto volume de publicação, ele não constará entre os pesquisadores em destaque nessa seção, o que não invalida sua relevância para o campo.

Encerramos a primeira parte da análise dos resultados, que foi feita utilizando uma visão global da rede de pesquisadores, e partiremos, na sequência, para uma análise fracionada pelos eventos e periódicos. O objetivo é compreender as variações dentro de cada unidade de análise. Vale ressaltar que em alguns casos haverá redundância com a análise anterior, mas é necessário jogar luz nas particularidades. 


\subsection{Rede de Pesquisadores do ENAPEGS}

O Encontro Nacional de Pesquisadores em Gestão Social (ENAPEGS) é realizado pela Rede de Pesquisadores de Gestão Social (RGS) e organizado por centros de pesquisa no campo da Gestão Social. O encontro já teve oito edições realizadas entre os anos de 2007 e 2014.

A Rede de Pesquisadores do ENAPEGS é composta por 1.197 pesquisadores (vértices) e 1.884 ligações (arestas), sendo que 1.480 ligações são únicas e 404 são ligações duplicadas. A densidade da rede é de 0,0022897, ou seja, a relação entre o número total de arestas e o número máximo de arestas possíveis (se todos os vértices fossem ligados uns aos outros). Apenas $8,19 \%$ dos pesquisadores da rede publicaram artigos sem coautoria.

\section{Figura 7: Rede de Pesquisadores do ENAPEGS}

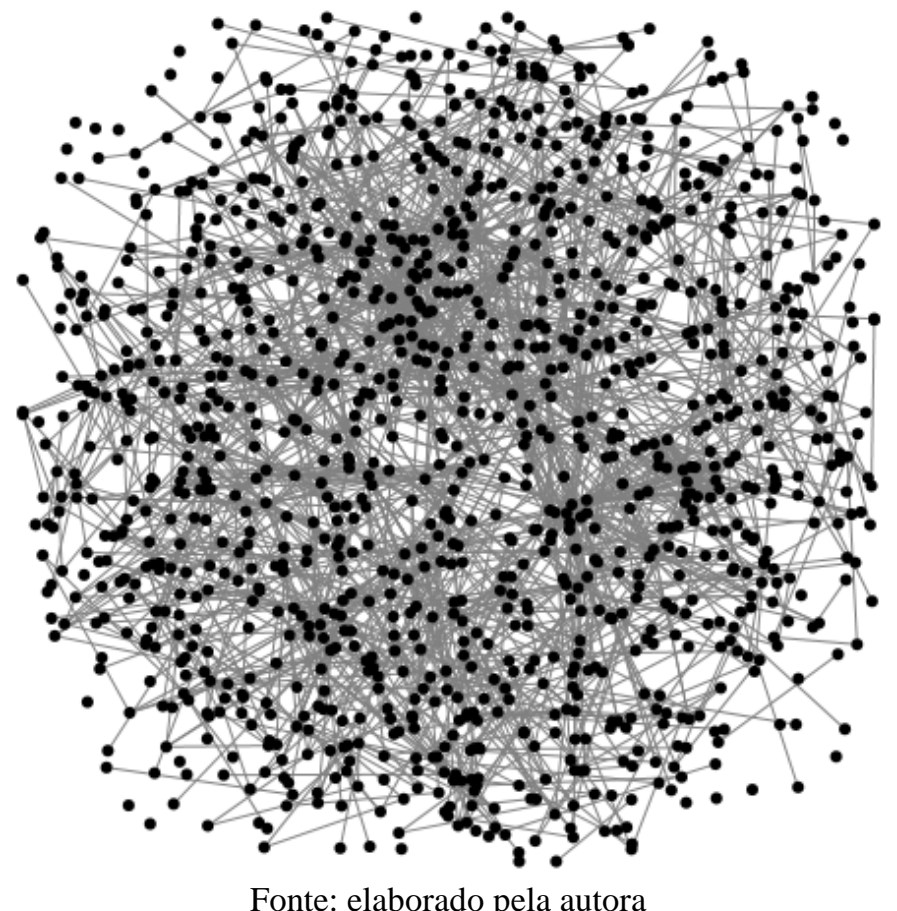

Fonte: elaborado pela autora

Os autores mais prolíficos da Rede de Pesquisadores do ENAPEGS são Marco Aurélio Marques Ferreira (22 publicações), José Roberto Pereira (19 publicações), Washington José de Souza (15 publicações), Magnus Luiz Emmendoerfer (14 publicações) e Rosinha da Silva Machado Carrion (13 publicações). 
Tabela 12: Autores mais prolíficos da Rede de Pesquisadores do ENAPEGS

\begin{tabular}{lc}
\hline \multicolumn{1}{c}{ Pesquisador } & $\mathbf{N}^{\mathbf{0}}$ de publicações \\
\hline MARCO AURÉLIO MARQUES FERREIRA & 22 \\
JOSÉ ROBERTO PEREIRA & 19 \\
WASHINGTON JOSÉ DE SOUZA & 15 \\
MAGNUS LUIZ EMMENDOERFER & 14 \\
ROSINHA DA SILVA MACHADO CARRION & 13 \\
\hline
\end{tabular}

Fonte: elaborado pela autora

Ao analisarmos as medidas de centralidade, notamos que Marco Aurélio Marques Ferreira, além de ser o autor mais prolífico, também apresenta a maior centralidade de grau (degree), o que representa 30 ligações dentro da rede. Na sequência, temos José Roberto Pereira, com 29 ligações, Magnus Luiz Emmendoerfer, com 26 ligações, e Airton Cardoso Cançado e Suely de Fátima Ramos Silveira, com 19 ligações cada um. Em relação à centralidade de intermediação (betweeneess), destacamos a pesquisadora Ariádne Scalfoni Rigo, que apresenta a maior medida da rede $(0,02754)$, e novamente os pesquisadores José Roberto Pereira e Magnus Luiz Emmendoerfer, que também constam entre os pesquisadores mais prolíficos, com maior centralidade de grau (degree) e centralidade de intermediação (betweeneess). Vale ressaltar que apontamos apenas um autor na centralidade de autovetor (eigenvector), pois houve a ocorrência do fenômeno de clique ${ }^{7}$, no qual todos os autores são one-timers, com exceção de Nelson Russo de Moraes. Na sequência, há ocorrência de outro clique, em que o pesquisador Nelson Russo de Moraes também publica um artigo com outros pesquisadores one-timers. Dessa forma, optamos por desprezar estas medidas, pois não representam pesquisadores relevantes para a rede.

Tabela 13: Medidas de centralidade da Rede de Pesquisadores do ENAPEGS

\begin{tabular}{ll}
\hline \multicolumn{1}{c}{ Pesquisador } & Medida \\
\hline Centralidade de grau (degree) & \\
\hline MARCO AURÉLIO MARQUES FERREIRA & 0,02508 \\
JOSÉ ROBERTO PEREIRA & 0,02425 \\
MAGNUS LUIZ EMMENDOERFER & 0,02174
\end{tabular}

\footnotetext{
7 “Um clique num gráfico é um subgráfico completo máximo de três ou mais nós. É constituído por um subconjunto de nós, todos os quais são adjacentes uns aos outros, e não há nós que também sejam adjacentes a todos os membros do clique.” (LUCE, PERRY, 1949; HARARY, NORMAN, CARTWRIGHT, 1965 apud WASSERMAN, FAUST, 2009) (tradução livre)
} 


\begin{tabular}{ll} 
AIRTON CARDOSO CANÇADO & 0,01589 \\
SUELY DE FÁTIMA RAMOS SILVEIRA & 0,01589 \\
\hline Centralidade de intermediação (betweeneess) & \\
\hline ARIÁDNE SCALFONI RIGO & 0,02754 \\
MAGNUS LUIZ EMMENDOERFER & 0,02363 \\
\hline JOSÉ ROBERTO PEREIRA & 0,01874 \\
ANA ALICE VILAS BOAS & 0,01842 \\
VÂNIA APARECIDA REZENDE DE OLIVEIRA & 0,01749 \\
\hline Centralidade de autovetor (eigenvector) & \\
\hline NELSON RUSSO DE MORAES & 0,08303
\end{tabular}

Figura 8: Representação gráfica da centralidade de grau (degree), centralidade de intermediação (betweenness) e centralidade de autovetor (eigenvector) da Rede de

Pesquisadores do ENAPEGS

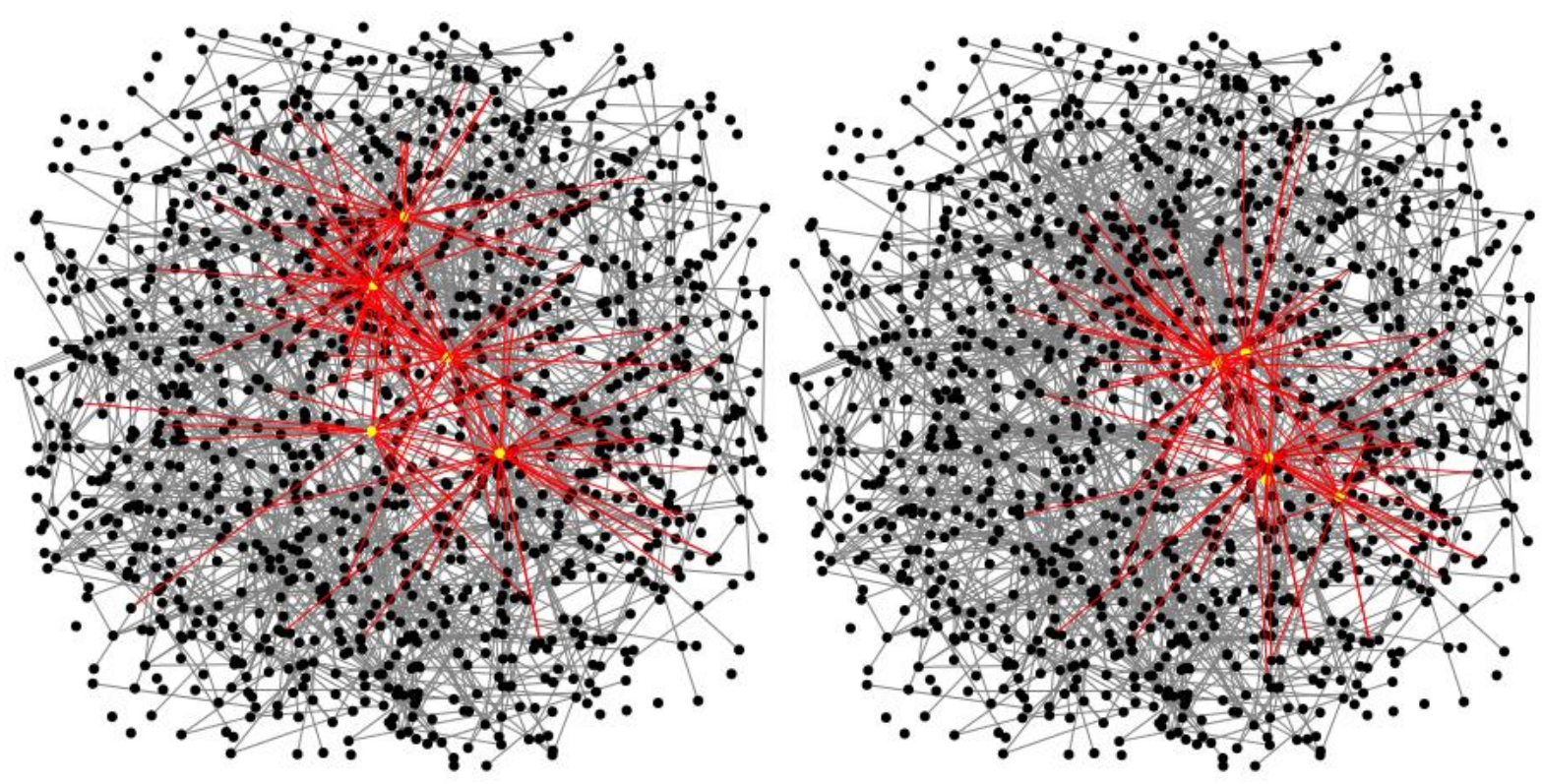




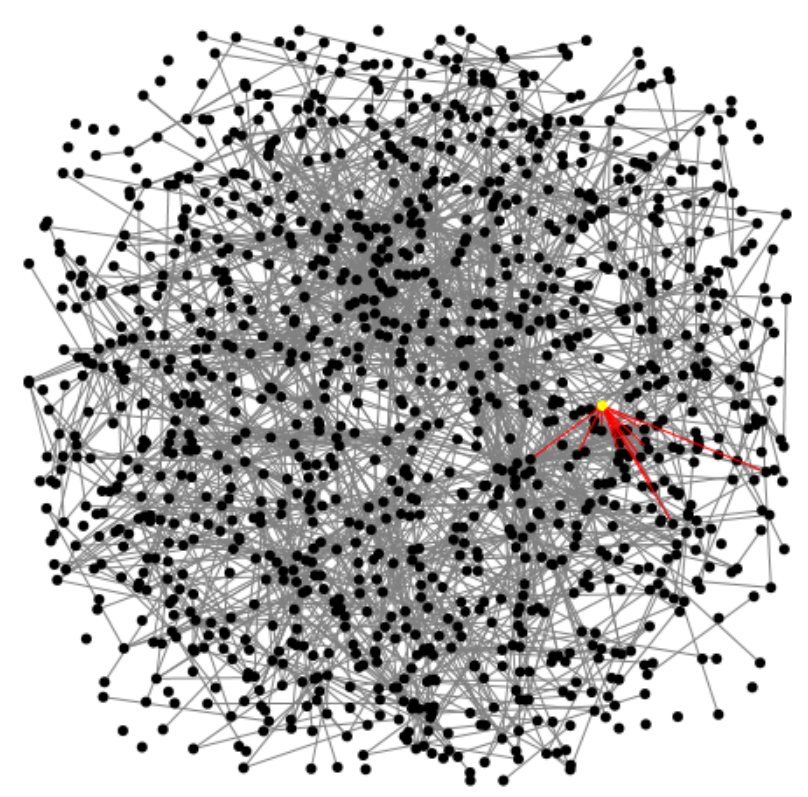

Fonte: elaborado pela autora

A Rede de Pesquisadores do ENAPEGS não apresenta preponderância de alguma instituição acadêmica específica. Podemos destacar que há duas fatias de $18 \%$ de pesquisadores que adquiriram sua última titulação acadêmica na Universidade Federal da Bahia e na Universidade Federal de Lavras. Ao analisar a instituição de atuação profisssional, notamos que $27 \%$ dos pesquisadores possuem vínculo com a Universidade Federal de Viçosa. Além disso, devemos destacar que $36 \%$ dos pesquisadores possuem doutorado por universidades mineiras e 54\% atuam profissionalmente em alguma universidade de Minas Gerais. Mais uma vez, é possível verificar que o estado mineiro é um importante polo de pesquisa no campo da Gestão Social.

\section{Quadro 15: Atributos dos principais autores da Rede de Pesquisadores do ENAPEGS}

\begin{tabular}{|l|c|c|c|c|c|c|}
\hline \multirow{2}{*}{ Pesquisador(a) } & \multicolumn{3}{c|}{ Formação acadêmica } & \multicolumn{2}{c|}{ Atuação profissional } \\
\cline { 2 - 7 } & $\begin{array}{c}\text { Última } \\
\text { titulação }\end{array}$ & Instituição & Área & Subárea & $\begin{array}{c}\text { Vínculo } \\
\text { Institucional }\end{array}$ & Instituição \\
\hline $\begin{array}{l}\text { AIRTON CARDOSO } \\
\text { CANÇADO }\end{array}$ & Doutorado & UFLA & Administração & Professor & UFT \\
\hline ANA ALICE VILAS BOAS & Doutorado & $\begin{array}{c}\text { The } \\
\text { University } \\
\text { of Reading }\end{array}$ & Administração & $\begin{array}{c}\text { Administração de } \\
\text { Empresas / } \\
\text { Administração de } \\
\text { Setores Específicos }\end{array}$ & Professora & UFLA \\
\hline $\begin{array}{l}\text { ARIÁDNE SCALFONI } \\
\text { RIGO }\end{array}$ & Doutorado & UFBA & Administração & Professora & UFBA \\
\hline
\end{tabular}




\begin{tabular}{|c|c|c|c|c|c|c|}
\hline $\begin{array}{l}\text { JOSÉ ROBERTO } \\
\text { PEREIRA }\end{array}$ & Doutorado & UnB & Sociologia & $\begin{array}{l}\text { Sociologia Rural / } \\
\text { Sociologia do } \\
\text { Desenvolvimento }\end{array}$ & Professor & UFLA \\
\hline $\begin{array}{l}\text { MAGNUS LUIZ } \\
\text { EMMENDOERFER }\end{array}$ & Doutorado & UFMG & $\begin{array}{c}\text { Sociologia / } \\
\text { Administração }\end{array}$ & $\begin{array}{c}\text { Sociologia } \\
\text { Econômica e das } \\
\text { Organizações / } \\
\text { Administração de } \\
\text { Empresas } \\
\end{array}$ & Professor & UFV \\
\hline $\begin{array}{l}\text { MARCO AURÉLIO } \\
\text { MARQUES FERREIRA }\end{array}$ & Doutorado & UFV & Administração & $\begin{array}{c}\text { Administração de } \\
\text { Setores Específicos } \\
\text { / Métodos } \\
\text { Quantitativos } \\
\text { Aplicados às } \\
\text { Ciências Sociais } \\
\end{array}$ & Professor & UFV \\
\hline $\begin{array}{l}\text { NELSON RUSSO DE } \\
\text { MORAES }\end{array}$ & Doutorado & UFBA & $\begin{array}{l}\text { Ciência } \\
\text { Política / } \\
\text { Filosofia }\end{array}$ & Teoria Política & Professor & UNESP \\
\hline $\begin{array}{l}\text { ROSINHA DA SILVA } \\
\text { MACHADO CARRION }\end{array}$ & Doutorado & UFRGS & $\begin{array}{c}\text { Sociologia / } \\
\text { Administração }\end{array}$ & $\begin{array}{c}\text { Sociologia do } \\
\text { Trabalho / } \\
\text { Administração de } \\
\text { Empresas } \\
\end{array}$ & Professora & UFRGS \\
\hline $\begin{array}{l}\text { SUELY DE FÁTIMA } \\
\text { RAMOS SILVEIRA }\end{array}$ & Doutorado & USP & Economia & $\begin{array}{c}\text { Métodos } \\
\text { Quantitativos em } \\
\text { Economia }\end{array}$ & Professora & UFV \\
\hline $\begin{array}{l}\text { VÂNIA APARECIDA } \\
\text { REZENDE DE OLIVEIRA }\end{array}$ & Doutorado & UFLA & Administração & & Professora & UFSJ \\
\hline $\begin{array}{l}\text { WASHINGTON JOSÉ DE } \\
\text { SOUZA }\end{array}$ & Doutorado & UFC & Educação & & Professor & UFRN \\
\hline
\end{tabular}

Fonte: elaborado pela autora com base na Plataforma Lattes

A maioria dos pesquisadores da Rede do ENAPEGS é composta por one-timers (38,27\%), seguindo a tendência da Rede de Pesquisadores de Gestão Social (RPGS). No entanto, o número de pesquisadores continuantes é bastante alto $(23,05 \%)$, se comparado à rede completa da área, que é de apenas 2,65\%. Na sequência, temos 17,86\% de pesquisadores transientes, $14,39 \%$ de pesquisadores retirantes e $6,33 \%$ de pesquisadores entrantes. Se somarmos as porcentagens dos pesquisadores continuantes e transientes, chegamos a $40,91 \%$ do total de pesquisadores. 
Tabela 14: Categorização dos Pesquisadores da Rede de Pesquisadores do ENAPEGS

\begin{tabular}{cc}
\hline Categoria & \% do total de autorias do evento \\
\hline Continuantes & $23,05 \%$ \\
Transientes & $17,86 \%$ \\
One-timers & $38,37 \%$ \\
Entrantes & $6,33 \%$ \\
Retirantes & $14,39 \%$ \\
\hline
\end{tabular}

Fonte: elaborado pela autora

De acordo com os dados apresentados, podemos concluir que o ENAPEGS é um evento típico do campo da Gestão Social, pois concentra um alto número (cerca de 8 vezes mais que a Rede de Pesquisadores de Gestão Social (RPGS)) de pesquisadores que possuem produção científica recente e regular, além de apontar nomes de pesquisadores tradicionais do campo, integrantes da Rede de Pesquisadores de Gestão Social (RGS), por exemplo. Em comparação com as demais redes é a que mais se assemelha à rede global de Pesquisadores em Gestão Social.

\subsection{Rede de Pesquisadores do EnANPAD}

O Encontro da Associação Nacional de Pós-Graduação e Pesquisa em Administração (EnANPAD) é realizado desde 1977. Para fins desta pesquisa, consideraremos o período de 2005 a 2015.

A Rede de Pesquisadores do EnANPAD é composta por 1.474 pesquisadores (vértices) e 1.917 ligações (arestas) entre eles, sendo 1.717 ligações únicas e 200 ligações duplicadas. Apenas 66 pesquisadores, ou seja, 4,48\%, publicaram artigos sozinhos, sem coautoria, em todo o período analisado. Isso denota que a Rede de Pesquisadores do EnANPAD é a mais colaborativa de todas as redes analisadas. 
Figura 9: Rede de Pesquisadores do EnANPAD

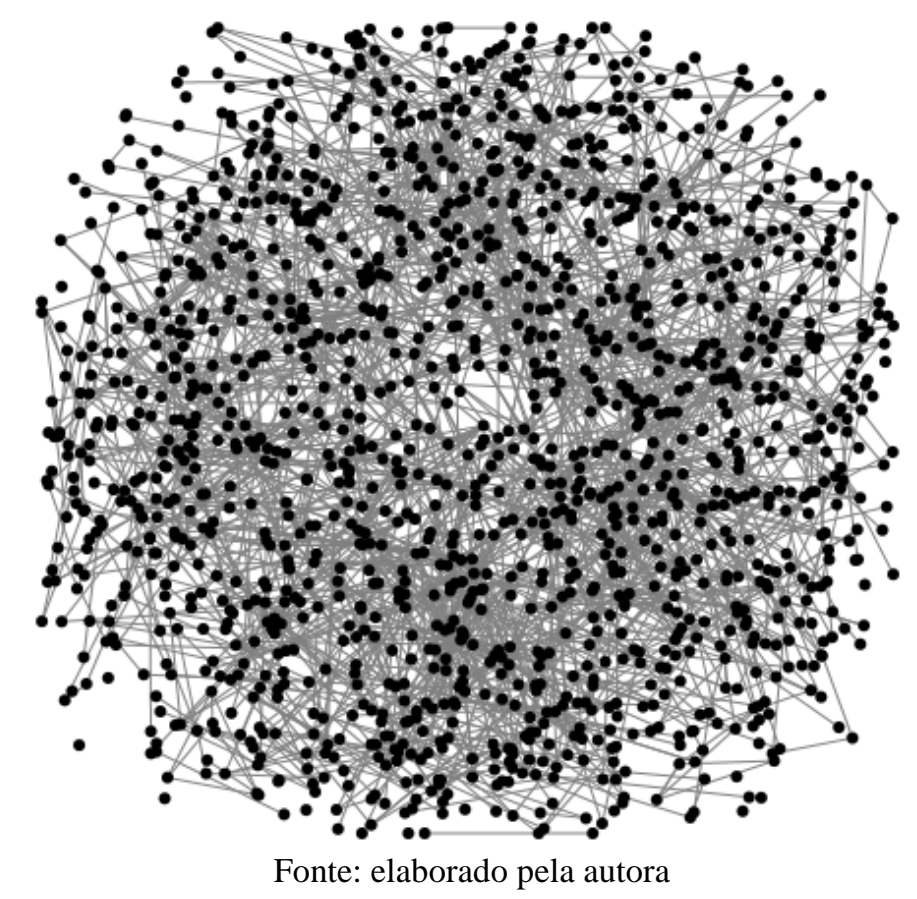

Os autores mais prolíficos da Rede de Pesquisadores do EnANPAD são: Mônica Cavalcanti Sá de Abreu, José Carlos Lázaro da Silva Filho, Francisco de Assis Soares, Hans Michael Van Bellen, José Célio Silveira Andrade, Ariádne Scalfoni Rigo e João Luiz Passador.

Tabela 15: Autores mais prolíficos da Rede de Pesquisadores do EnANPAD

\begin{tabular}{lc}
\hline \multicolumn{1}{c}{ Pesquisador } & $\mathbf{N}^{\mathbf{0}}$ de publicações \\
\hline MÔNICA CAVALCANTI SÁ DE ABREU & 13 \\
JOSÉ CARLOS LÁZARO DA SILVA FILHO & 9 \\
FRANCISCO DE ASSIS SOARES & 9 \\
HANS MICHAEL VAN BELLEN & 8 \\
JOSÉ CÉLIO SILVEIRA ANDRADE & 7 \\
ARIÁDNE SCALFONI RIGO & 7 \\
JOÃO LUIZ PASSADOR & 7 \\
\hline
\end{tabular}

Fonte: elaborado pela autora

A análise das medidas de centralidade (grau/degree, intermediação/betweenness e autovetor/eigenvector) revelam que a pesquisadora Mônica Cavalcanti Sá de Abreu, além de ser a pesquisadora mais prolífica da rede, com 13 publicações no período analisado, também apresenta as maiores medidas de centralidade. O pesquisador Francisco de Assis Soares 
também aparece como um dos pesquisadores mais prolíficos e com uma das maiores medidas de centralidade de grau e autovetor da rede. Assim como o pesquisador José Carlos Lázaro da Silva Filho, que se destaca como um dos autores mais prolíficos, além de figurar entre os pesquisadores com altas medidas de centralidade grau e autovetor.

Tabela 16: Medidas de centralidade da Rede de Pesquisadores do EnANPAD

\begin{tabular}{ll}
\hline \multicolumn{1}{c}{ Pesquisador } & Medida \\
\hline Centralidade de grau (degree) & \\
\hline MÔNICA CAVALCANTI SÁ DE ABREU & 0,01358 \\
\hline JOSÉ CÉLIO SILVEIRA ANDRADE & 0,01018 \\
\hline FRANCISCO DE ASSIS SOARES & 0,00815 \\
\hline DENISE CARNEIRO DOS REIS BERNARDO & 0,00815 \\
\hline JOSÉ CARLOS LÁZARO DA SILVA FILHO & 0,00747 \\
\hline JOÃO LUIZ PASSADOR & 0,00747 \\
\hline Centralidade de intermediação (betweeneess) & \\
\hline MÔNICA CAVALCANTI SÁ DE ABREU & 0,00064 \\
\hline AUGUSTO CÉZAR DE AQUINO CABRAL & 0,00060 \\
\hline ANDRÉ LUIZ FISCHER & 0,00057 \\
\hline WILSON APARECIDO COSTA DE AMORIM & 0,00052 \\
RAQUEL DA SILVA PEREIRA & 0,00050 \\
\hline Centralidade de autovetor (eigenvector) & \\
\hline MÔNICA CAVALCANTI SÁ DE ABREU & 0,10800 \\
\hline FRANCISCO DE ASSIS SOARES & 0,08500 \\
\hline JOSÉ CARLOS LÁZARO DA SILVA FILHO & 0,07000 \\
\hline BRUNO CALS DE OLIVEIRA & 0,06200 \\
\hline FRANCISCO LEITE HOLANDA JÚNIOR & 0,05029 \\
\hline NICOLAS RENATO SIQUEIRA ARAUJO & 0,05029 \\
\hline
\end{tabular}

Fonte: elaborado pela autora

Na figura 10, podemos visualizar as representações gráficas de cada uma das medidas de centralidade. 
Figura 10: Representação gráfica da centralidade de grau (degree), centralidade de intermediação (betweenness) e centralidade de autovetor (eigenvector) da Rede de

\section{Pesquisadores do EnANPAD}
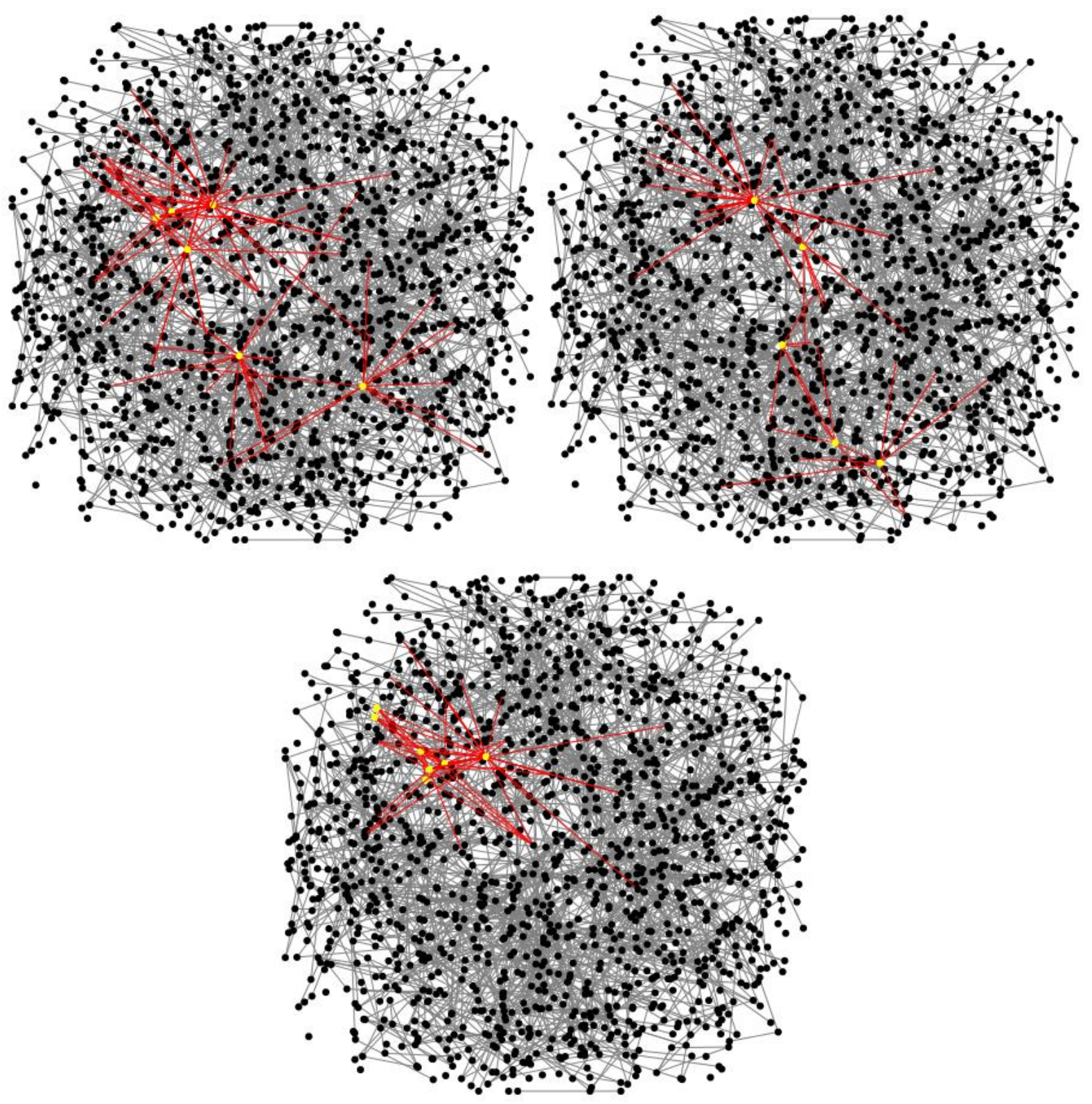

Fonte: elaborado pela autora

Em relação à formação acadêmica dos pesquisadores destacados acima, podemos notar que 47,67\% possuem doutorado pelas seguintes instituições: Universidade de São Paulo (3 pesquisadores), Universidade Federal da Bahia (2 pesquisadores) e Universidade Federal de Santa Catarina (2 pesquisadores). Considerando a instituição em que os pesquisadores atuam profissionalmente, verificamos que $26,67 \%$ estão vinculados à Universidade Federal do Ceará, $20 \%$ à Universidade de São Paulo e 13,33\% à Universidade Federal da Bahia. Ao 
contrário das redes analisadas anteriormente, a Rede de Pesquisadores do EnANPAD apresenta uma melhor distribuição geográfica e institucional dos pesquisadores.

Quadro 16: Atributos dos principais autores da Rede de Pesquisadores do EnANPAD ${ }^{8}$

\begin{tabular}{|c|c|c|c|c|c|c|}
\hline \multirow[b]{2}{*}{ Pesquisador(a) } & \multicolumn{4}{|c|}{ Formação acadêmica } & \multicolumn{2}{|c|}{ Atuação profissional } \\
\hline & $\begin{array}{l}\text { Última } \\
\text { titulação }\end{array}$ & Instituição & Área & Subárea & $\begin{array}{c}\text { Vínculo } \\
\text { Institucional }\end{array}$ & Instituição \\
\hline ANDRÉ LUIZ FISCHER & Doutorado & USP & Administração & $\begin{array}{l}\text { Administração de } \\
\text { Empresas }\end{array}$ & Professor & USP \\
\hline $\begin{array}{l}\text { ARIÁDNE SCALFONI } \\
\text { RIGO }\end{array}$ & Doutorado & UFBA & Administração & & Professora & UFBA \\
\hline $\begin{array}{l}\text { AUGUSTO CÉZAR DE } \\
\text { AQUINO CABRAL }\end{array}$ & Doutorado & UFMG & Administração & $\begin{array}{l}\text { Administração de } \\
\text { Empresas }\end{array}$ & Professor & UFC \\
\hline $\begin{array}{l}\text { BRUNO CALS DE } \\
\text { OLIVEIRA }\end{array}$ & Doutorado & USP & Administração & & Professor & FIA \\
\hline $\begin{array}{l}\text { DENISE CARNEIRO DOS } \\
\text { REIS BERNARDO }\end{array}$ & Doutorado & UFLA & Administração & $\begin{array}{l}\text { Administração de } \\
\text { Empresas }\end{array}$ & Professora & UFSJ \\
\hline $\begin{array}{l}\text { FRANCISCO DE ASSIS } \\
\text { SOARES }\end{array}$ & Mestrado & UFC & Economia & $\begin{array}{c}\text { Métodos } \\
\text { Quantitativos em } \\
\text { Economia } \\
\end{array}$ & Professor & UFC \\
\hline $\begin{array}{l}\text { HANS MICHAEL VAN } \\
\text { BELLEN }\end{array}$ & Doutorado & UFSC & $\begin{array}{l}\text { Engenharia de } \\
\text { Produção }\end{array}$ & & Professor & $\begin{array}{l}\text { UFSC / } \\
\text { UNISUL }\end{array}$ \\
\hline JOÃO LUIZ PASSADOR & Doutorado & FGV/SP & Administração & $\begin{array}{l}\text { Administração } \\
\text { Pública }\end{array}$ & Professor & USP \\
\hline $\begin{array}{l}\text { JOSÉ CARLOS LÁZARO } \\
\text { DA SILVA FILHO }\end{array}$ & Doutorado & $\begin{array}{l}\text { Technische } \\
\text { Universität- } \\
\text { Berlin }\end{array}$ & Administração & Política Ambiental & Professor & UFC \\
\hline $\begin{array}{l}\text { JOSÉ CÉLIO SILVEIRA } \\
\text { ANDRADE }\end{array}$ & Doutorado & UFBA & Administração & $\begin{array}{l}\text { Administração de } \\
\text { Empresas }\end{array}$ & Professor & UFBA \\
\hline $\begin{array}{l}\text { MÔNICA CAVALCANTI } \\
\text { SÁ DE ABREU }\end{array}$ & Doutorado & UFSC & $\begin{array}{l}\text { Engenharia de } \\
\text { Produção }\end{array}$ & & Professor & UFC \\
\hline $\begin{array}{l}\text { NICOLAS RENATO } \\
\text { SIQUEIRA ARAUJO }\end{array}$ & Doutorado & UFPB & Administração & $\begin{array}{l}\text { Administração de } \\
\text { Empresas }\end{array}$ & Professor & $\begin{array}{l}\text { Faculdade } \\
\text { Santa Cruz }\end{array}$ \\
\hline $\begin{array}{l}\text { RAQUEL DA SILVA } \\
\text { PEREIRA }\end{array}$ & Doutorado & PUC/SP & $\begin{array}{l}\text { Administração } \\
\text { / Sociologia }\end{array}$ & & Professora & USCS \\
\hline
\end{tabular}

\footnotetext{
${ }^{8}$ Não encontramos os dados do pesquisador Francisco Leite Holanda Júnior
} 


\begin{tabular}{|l|l|l|l|c|c|c|}
\hline $\begin{array}{l}\text { WILSON APARECIDO } \\
\text { COSTA DE AMORIM }\end{array}$ & Doutorado & USP & $\begin{array}{c}\text { Economia / } \\
\text { Educação }\end{array}$ & $\begin{array}{c}\text { Economia dos } \\
\text { Recursos Humanos } \\
\text { / Ensino- } \\
\text { Aprendizagem }\end{array}$ & Professor & USP \\
\hline
\end{tabular}

Fonte: elaborado pela autora com base na Plataforma Lattes

Por fim, a última categoria de análise que iremos apontar os resultados considera a regularidade da produção científica dos pesquisadores. Novamente, como nas demais redes já tratadas anteriormente, o percentual de pesquisadores one-timers é alto, chegando a 44,49\% do total. Na sequência, temos que $18,94 \%$ dos pesquisadores são transientes, $17,23 \%$ são retirantes, $14,24 \%$ são continuantes e apenas $4,39 \%$ são entrantes.

Tabela 17: Categorização dos Pesquisadores da Rede de Pesquisadores do EnANPAD

\begin{tabular}{cc}
\hline Categoria & \% do total de autorias do evento \\
\hline Continuantes & $14,24 \%$ \\
Transientes & $18,94 \%$ \\
One-timers & $44,49 \%$ \\
Entrantes & $4,39 \%$ \\
Retirantes & $17,93 \%$ \\
\hline \multicolumn{2}{c}{ Fonte: elaborado pela autora } \\
\hline
\end{tabular}

O resultado encontrado na Rede de Pesquisadores do EnANPAD pode estar atrelado à amplitude da subárea de Gestão Social e Ambiental do EnANPAD, que vigorou de 2005 a 2009, pois os autores em destaque não são típicos do campo da Gestão Social. Outro fator que devemos destacar é que a extinção de um tema específico de Gestão Social provocou a diminuição da presença de pesquisadores tradicionais da Rede de Pesquisadores de Gestão Social (RGS). 


\subsection{Rede de Pesquisadores do Colóquio Internacional sobre o Poder Local}

O Colóquio Internacional sobre o Poder Local é realizado pelo Núcleo de Estudos sobre Poder e Organizações Locais (NEPOL), vinculado ao Núcleo de Pós-Graduação NPGA da Escola de Administração da Universidade Federal da Bahia.

A Rede de Pesquisadores do Colóquio Internacional sobre o Poder Local é composta por 1.139 vértices (pesquisadores), sendo que 124 deles publicaram apenas artigos sem nenhuma coautoria. Conforme dito acima, do total de pesquisadores da rede, apenas 10,89\% (124 pesquisadores) não possuem nenhuma ligação. A rede também apresenta um total de 1.466 arestas (ligação entre dois vértices), das quais 1.277 são arestas únicas e 189 são arestas duplicadas. Isso significa que há 189 casos em que uma dupla de pesquisadores publicou conjuntamente mais de uma vez. A densidade da rede é de 0,0021031. Por meio da figura 11, podemos verificar que a rede possui um alto número de pesquisadores e de ligações entre eles.

Figura 11: Rede de Pesquisadores do Colóquio Internacional sobre o Poder Local

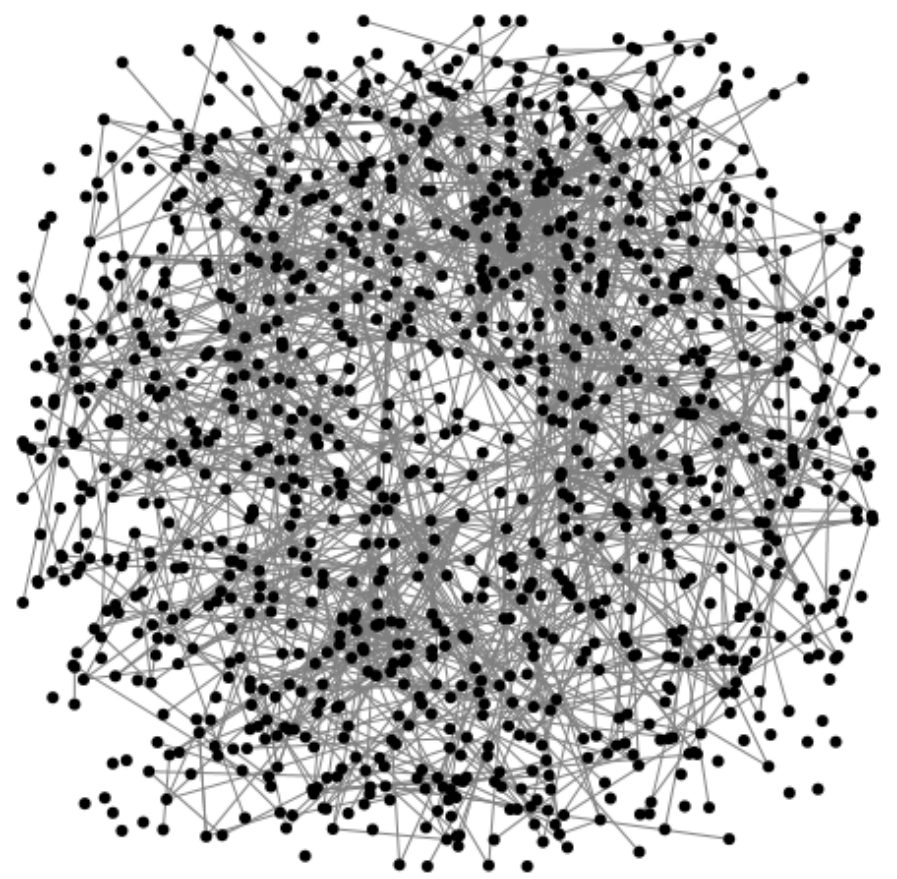

Fonte: elaborado pela autora

Quando analisamos os autores mais prolíficos deste evento, notamos que os pesquisadores Alexandre de Pádua Carrieri e Marta Ferreira Santos Farah estão no topo com 8 
trabalhos apresentados cada um, seguidos de Lamounier Erthal Villela, Marlene Catarina de Oliveira Lopes Melo e Neusa Rolita Cavedon com 7 trabalhos cada um.

Tabela 18: Autores mais prolíficos da Rede de Pesquisadores do Colóquio Internacional sobre o Poder Local

\begin{tabular}{lc}
\hline \multicolumn{1}{c}{ Pesquisador } & $\mathbf{N}^{\mathbf{0}}$ de publicações \\
\hline ALEXANDRE DE PÁDUA CARRIERI & 8 \\
MARTA FERREIRA SANTOS FARAH & 8 \\
LAMOUNIER ERTHAL VILLELA & 7 \\
MARLENE CATARINA DE OLIVEIRA LOPES MELO & 7 \\
NEUSA ROLITA CAVEDON & 7 \\
\hline \multicolumn{2}{l}{ Fonte: elaborado pela autora }
\end{tabular}

Outra característica que podemos analisar é a importância relativa de um vértice em uma rede. A primeira medida que analisaremos será a centralidade de grau (degree), cujos autores que apresentaram os maiores valores são: José Célio Silveira Andrade, com 0,01494 (17 laços), Alexandre de Pádua Carrieri, com 0,01318 (15 laços), Reginaldo Souza Santos, com 0,01230 (14 laços), Armindo dos Santos de Sousa Teodósio, com 0,01142 (13 laços), e Ana Sílvia Rocha Ipiranga, com 0,01054 (12 laços).

Em relação à centralidade de intermediação (betweeneess), notamos que o pesquisador Alexandre de Pádua Carrieri se destaca novamente, apresentando a maior medida $(0,00111)$, seguido dos pesquisadores Carolina Machado Saraiva de Albuquerque Maranhão (0,00070), Denise Franca Barros $(0,00044)$, Ivan Beck Ckagnazaroff $(0,00044)$ e Suzane Strehlau $(0,00036)$.

Já na medida de centralidade de autovetor (eigenvector), destacam-se Reginaldo Souza Santos (0,10724), Elizabeth Matos Ribeiro (0,09999), Weslei Gusmão Piau Santana $(0,01881)$, Elinaldo Leal Santos $(0,01748)$ e Vitor Lélio Braga $(0,01748)$. Vale assinalar que Cleber Dias da Silva Júnior, Daniel Andrade Caribé, Fábio Guedes Gomes, Iará Martins Icó Souto, Leidimar Candida dos Santos, Mônica Matos Ribeiro e Thiago Chagas Silva Santos apresentaram uma centralidade de autovetor (eigenvector) de 0,093747. No entanto, optamos por não incluí-los na tabela 19, pois notamos que eles fazem parte de um “clique".

Todos os pesquisadores desse grupo, com exceção de Fábio Guedes Gomes, são onetimers. Os pesquisadores citados anteriormente (Cleber Dias da Silva Júnior, Daniel Andrade Caribé, Fábio Guedes Gomes, Iará Martins Icó Souto, Leidimar Candida dos Santos, Mônica 
Matos Ribeiro e Thiago Chagas Silva Santos) publicaram um único artigo, sendo este em conjunto com Reginaldo Souza Santos e Elizabeth Matos Ribeiro no evento de 2006. Fábio Guedes Gomes é classificado como retirante, tendo apenas 2 artigos publicados em todo o período analisado.

O mesmo caso pode ser observado com os pesquisadores que possuem a $4^{\mathrm{a}}$ maior medida de centralidade de autovetor (eigenvector): Eduardo Fausto Barreto e Maria Da Graça Pitiá Barreto, ambos com uma medida de centralidade de autovetor (eigenvector) de 0,02874. Os dois são one-timers e publicaram um único artigo, sendo este também na companhia de Reginaldo Souza Santos e Elizabeth Matos Ribeiro no evento de 2009.

Os próximos pesquisadores na ordem de maior medida de centralidade de autovetor (eigenvector) são Elinaldo Leal Santos e Vitor Lélio Braga, que, embora pertençam a um “clique”, não são pesquisadores one-timers e possuem artigos publicados com outros atores da rede.

\section{Tabela 19: Medidas de centralidade da Rede de Pesquisadores do Colóquio Internacional sobre o Poder Local}

\begin{tabular}{lc}
\hline \multicolumn{1}{c}{ Pesquisador } & Medida \\
\hline Centralidade de grau (degree) & \\
\hline JOSÉ CÉLIO SILVEIRA ANDRADE & 0,01494 \\
ALEXANDRE DE PÁDUA CARRIERI & 0,01318 \\
\hline REGINALDO SOUZA SANTOS & 0,01230 \\
ARMINDO DOS SANTOS DE SOUSA TEODÓSIO & 0,01142 \\
\hline ANA SÍLVIA ROCHA IPIRANGA & 0,01054 \\
\hline Centralidade de intermediação (betweeneess) & \\
\hline ALEXANDRE DE PÁDUA CARRIERI & 0,00111 \\
CAROLINA MACHADO SARAIVA DE ALBUQUERQUE MARANHÃO & 0,00070 \\
\hline DENISE FRANCA BARROS & 0,00044 \\
IVAN BECK CKAGNAZAROFF & 0,00044 \\
\hline SUZANE STREHLAU & 0,00036 \\
\hline Centralidade de autovetor (eigenvector) & \\
\hline REGINALDO SOUZA SANTOS & 0,10724 \\
\hline ELIZABETH MATOS RIBEIRO & 0,09999 \\
\hline WESLEI GUSMÃO PIAU SANTANA & 0,01881 \\
\hline ELINALDO LEAL SANTOS & 0,01748 \\
\hline VITOR LÉLIO BRAGA & 0,01748 \\
\hline
\end{tabular}


Abaixo podemos ver a representação gráfica das três medidas de centralidade citadas acima.

Figura 12: Representação gráfica da centralidade de grau (degree), centralidade de intermediação (betweenness) e centralidade de autovetor (eigenvector) da Rede de Pesquisadores do Colóquio Internacional sobre o Poder Local
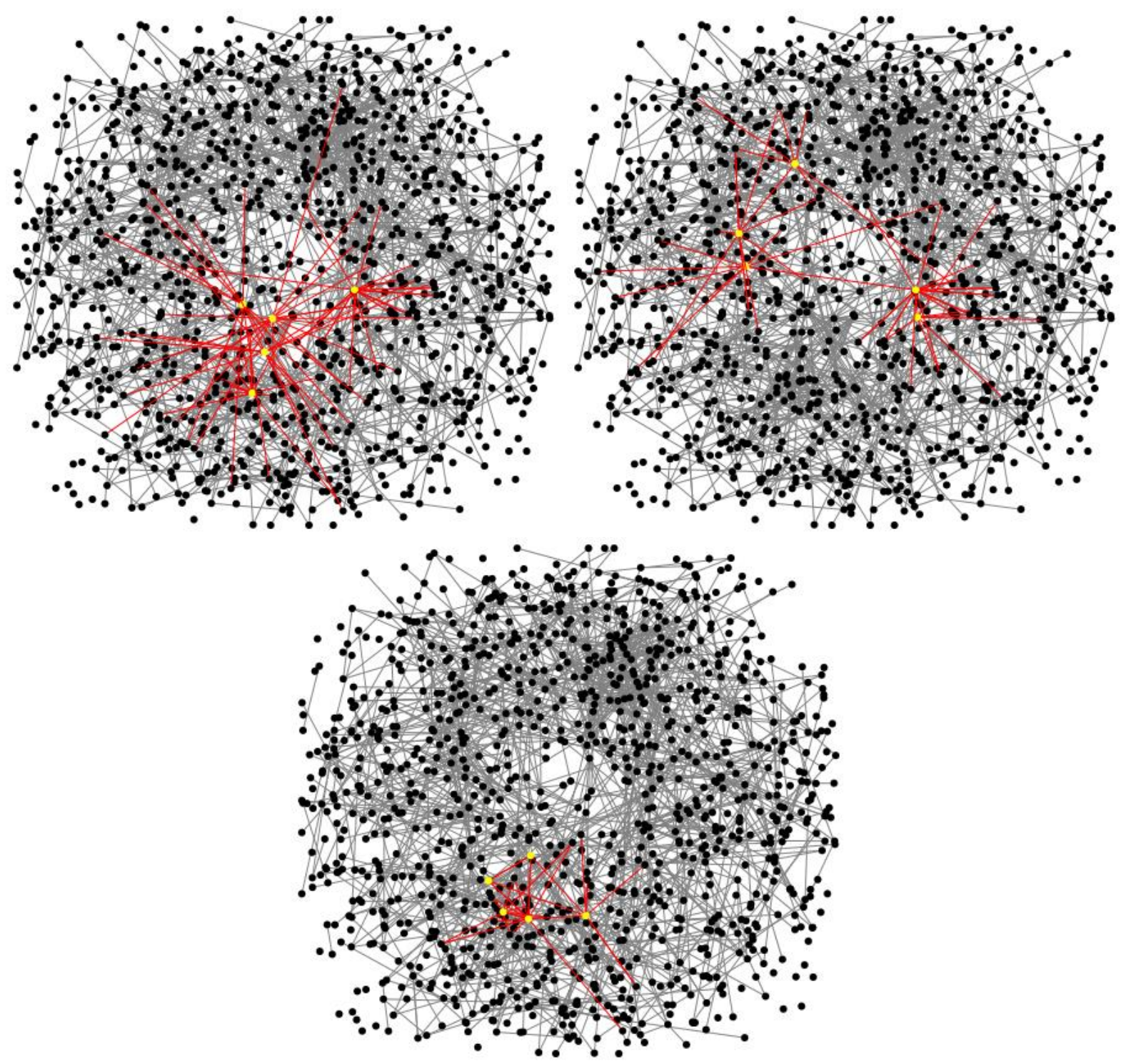

Fonte: elaborado pela autora

Ao analisarmos a vinculação institucional, tanto da formação acadêmica quanto da atuação profissional, notamos que $17,65 \%$ dos pesquisadores adquiriram sua última titulação acadêmica na Universidade Federal da Bahia e 17,65\% dos pesquisadores atuam profissionalmente como pesquisadores na mesma instituição. Ainda em relação à formação acadêmica, podemos apontar que 35,29\% dos pesquisadores cursaram o doutorado em 
universidades estrangeiras, nas áreas de Ciência Política, Psicologia, Economia e Administração.

\section{Quadro 17: Atributos dos principais autores da Rede de Pesquisadores do Colóquio Internacional sobre o Poder Local}

\begin{tabular}{|c|c|c|c|c|c|c|}
\hline \multirow{2}{*}{ Pesquisador(a) } & \multicolumn{3}{|c|}{ Formação acadêmica } & \multicolumn{3}{|c|}{ Atuação profissional } \\
\hline & $\begin{array}{l}\text { Última } \\
\text { titulação }\end{array}$ & Instituição & Área & Subárea & $\begin{array}{c}\text { Vínculo } \\
\text { Institucional }\end{array}$ & Instituição \\
\hline $\begin{array}{l}\text { ALEXANDRE DE } \\
\text { PÁDUA CARRIERI }\end{array}$ & Doutorado & UFMG & Administração & $\begin{array}{l}\text { Administração de } \\
\text { Empresas }\end{array}$ & Professor & UFMG \\
\hline $\begin{array}{l}\text { ANA SÍLVIA } \\
\text { ROCHA IPIRANGA }\end{array}$ & Doutorado & $\begin{array}{c}\text { Universita di } \\
\text { Bologna }\end{array}$ & $\begin{array}{l}\text { Ciência Política } \\
\text { / Psicologia }\end{array}$ & $\begin{array}{c}\text { Comportamento } \\
\text { Político / } \\
\text { Psicologia Social }\end{array}$ & Professora & UECE \\
\hline $\begin{array}{l}\text { ARMINDO DOS } \\
\text { SANTOS DE } \\
\text { SOUSA TEODÓSIO }\end{array}$ & Doutorado & FGV/SP & Administração & $\begin{array}{c}\text { Administração de } \\
\text { Empresas / } \\
\text { Administração } \\
\text { Pública }\end{array}$ & Professor & $\mathrm{PUC} / \mathrm{MG}$ \\
\hline \begin{tabular}{|l} 
CAROLINA \\
MACHADO \\
SARAIVA DE \\
ALBUQUERQUE \\
MARANHÃO \\
\end{tabular} & Doutorado & UFMG & Administração & $\begin{array}{c}\text { Estudos Críticos } \\
\text { em } \\
\text { Administração }\end{array}$ & Professora & UFOP \\
\hline $\begin{array}{l}\text { DENISE FRANCA } \\
\text { BARROS }\end{array}$ & Doutorado & FGV & Administração & & Professora & UNIGRANRIO \\
\hline $\begin{array}{l}\text { ELINALDO LEAL } \\
\text { SANTOS }\end{array}$ & Doutorado & UFBA & Administração & & Professor & UESB \\
\hline $\begin{array}{l}\text { ELIZABETH } \\
\text { MATOS RIBEIRO }\end{array}$ & Doutorado & $\begin{array}{c}\text { Universidade } \\
\text { de Santiago } \\
\text { de } \\
\text { Compostela }\end{array}$ & Ciência Política & $\begin{array}{c}\text { Estado e } \\
\text { Políticas Públicas } \\
\text { / Políticas } \\
\text { Públicas }\end{array}$ & Professora & UFBA \\
\hline $\begin{array}{l}\text { IVAN BECK } \\
\text { CKAGNAZAROFF }\end{array}$ & Doutorado & $\begin{array}{l}\text { Aston } \\
\text { University }\end{array}$ & Administração & $\begin{array}{l}\text { Administração } \\
\text { Pública }\end{array}$ & Professor & UFMG \\
\hline $\begin{array}{l}\text { JOSÉ CÉLIO } \\
\text { SILVEIRA } \\
\text { ANDRADE }\end{array}$ & Doutorado & UFBA & Administração & $\begin{array}{l}\text { Administração de } \\
\text { Empresas }\end{array}$ & Professor & UFBA \\
\hline $\begin{array}{l}\text { LAMOUNIER } \\
\text { ERTHAL VILLELA }\end{array}$ & Doutorado & $\begin{array}{l}\text { Université } \\
\text { Sorbonne } \\
\text { Nouvelle - } \\
\text { Paris } 3\end{array}$ & Economia & $\begin{array}{c}\text { Crescimento, } \\
\text { Flutuações e } \\
\text { Planejamento } \\
\text { Econômico / } \\
\text { Economia do } \\
\text { Bem-Estar Social }\end{array}$ & Professor & UFRRJ \\
\hline $\begin{array}{l}\text { MARLENE } \\
\text { CATARINA DE } \\
\text { OLIVEIRA LOPES } \\
\text { MELO }\end{array}$ & Doutorado & $\begin{array}{l}\text { Université } \\
\text { Paris- } \\
\text { Dauphine - } \\
\text { Paris IX }\end{array}$ & $\begin{array}{l}\text { Ciências das } \\
\text { Organizações }\end{array}$ & & Professora & $\begin{array}{l}\text { Faculdade } \\
\text { Novos } \\
\text { Horizontes }\end{array}$ \\
\hline
\end{tabular}




\begin{tabular}{|l|l|l|l|l|l|l|}
\hline $\begin{array}{l}\text { MARTA FERREIRA } \\
\text { SANTOS FARAH }\end{array}$ & Doutorado & USP & Sociologia & & FGV/SP \\
\hline $\begin{array}{l}\text { NEUSA ROLITA } \\
\text { CAVEDON }\end{array}$ & Doutorado & UFRGS & Administração & $\begin{array}{c}\text { Administração de } \\
\text { Setores } \\
\text { Específicos }\end{array}$ & Professora & UFRGS \\
\hline $\begin{array}{l}\text { REGINALDO } \\
\text { SOUZA SANTOS }\end{array}$ & Doutorado & UNICAMP & $\begin{array}{c}\text { Ciências } \\
\text { Econômicas }\end{array}$ & & Professor & UFBA \\
\hline $\begin{array}{l}\text { SUZANE } \\
\text { STREHLAU }\end{array}$ & Doutorado & FGV/SP & $\begin{array}{c}\text { Administração } \\
\text { de Empresas }\end{array}$ & Professora & UNINOVE \\
\hline $\begin{array}{l}\text { VITOR LÉLIO } \\
\text { BRAGA }\end{array}$ & Doutorado & $\begin{array}{c}\text { University } \\
\text { Business } \\
\text { School }\end{array}$ & & & Professor & Politécnico do \\
Porto
\end{tabular}

Fonte: elaborado pela autora com base na Plataforma Lattes

A análise das categorias dos autores que apresentaram trabalhos no Colóquio Internacional sobre o Poder Local, segundo sua regularidade de produção, apresentou a seguinte configuração: $39,25 \%$ são one-timers, $32,48 \%$ são retirantes, $16,08 \%$ são continuantes, $12,19 \%$ são transientes e não houve registro de nenhum entrante. Isso porque o último evento foi realizado em 2012, mais de três anos do último ano considerado no estudo.

\section{Tabela 20: Categorização dos Pesquisadores da Rede de Pesquisadores do Colóquio Internacional sobre o Poder Local}

\begin{tabular}{cc}
\hline Categoria & \% do total de autorias do evento \\
\hline Continuantes & $16,08 \%$ \\
Transientes & $12,19 \%$ \\
One-timers & $39,25 \%$ \\
Entrantes & $0,00 \%$ \\
Retirantes & $32,48 \%$ \\
\hline
\end{tabular}

Fonte: elaborado pela autora

Podemos notar que boa parte dos pesquisadores em destaque é ligada à Universidade Federal da Bahia (UFBA) ou universidades da região. Outro fator que podemos destacar é a presença de pesquisadores que trabalham o tema da Teoria das Organizações e o tema da Administração Pública. 


\subsection{Rede de Pesquisadores do EnAPG}

O EnAPG - Encontro de Administração Pública e Governança é realizado bienalmente pela Associação Nacional de Pós-Graduação e Pesquisa em Administração ANPAD, sendo que sua primeira edição ocorreu em 2004.

A Rede de Pesquisadores do EnAPG é composta por 375 pesquisadores (vértices) e 436 ligações (arestas) entre os pesquisadores, sendo que 408 delas são ligações únicas e 28 duplicadas. Do total dos 375 pesquisadores, apenas 28 deles $(7,47 \%)$ não fizeram nenhuma parceria na rede, ou seja, não publicaram artigos com coautoria de outros pesquisadores. A densidade da Rede de Pesquisadores do EnAPG é de 0,0060036.

Figura 13: Rede de Pesquisadores do EnAPG

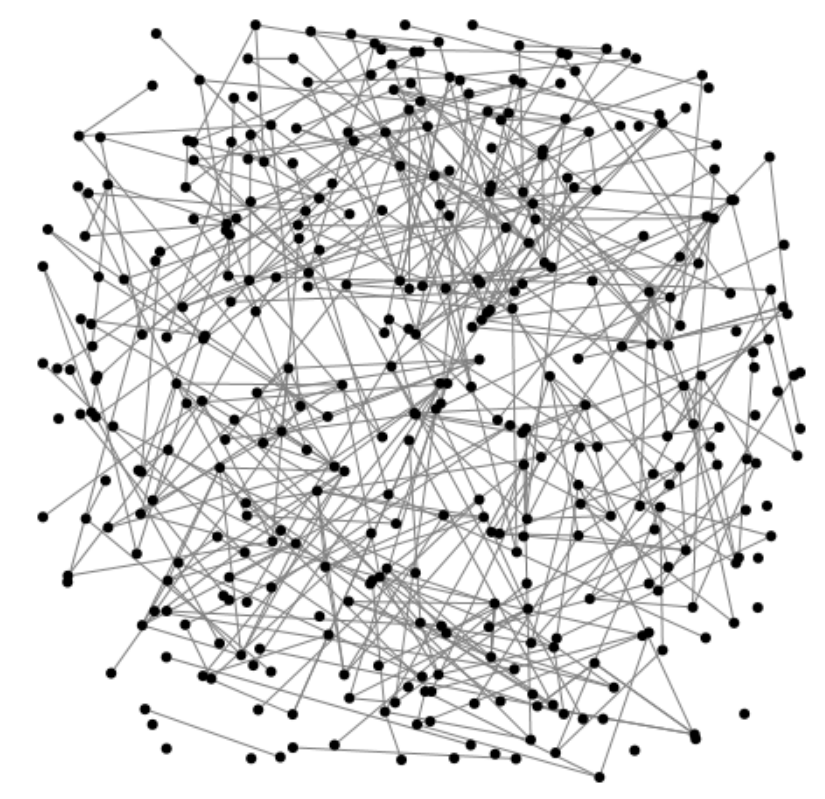

Fonte: elaborado pela autora

Os autores mais prolíficos da Rede de Pesquisadores do EnAPG são José Antonio Gomes de Pinho, José Franciso Salm e Maria Ester Menegasso, com 4 publicações cada um. Optamos por apontar apenas os três primeiros autores do ranking, pois na sequência há 11 pesquisadores com 3 publicações cada. 
Tabela 21: Autores mais prolíficos da Rede de Pesquisadores do EnAPG

\begin{tabular}{lc}
\hline \multicolumn{1}{c}{ Pesquisador } & No de publicações $^{\mathbf{0}}$ \\
\hline JOSÉ ANTÔNIO GOMES DE PINHO & 4 \\
JOSÉ FRANCISCO SALM & 4 \\
MARIA ESTER MENEGASSO & 4 \\
\hline
\end{tabular}

Fonte: elaborado pela autora

Em relação às medidas de centralidade, Maria Carolina Martinez Andion apresentou as maiores medidas de centralidade de grau (degree) e de intermediação (betweeneess) da rede. Destaca-se também Fernando Guilherme Tenório, que aparece entre os cinco pesquisadores com as maiores medidas nas três centralidades: grau (degree), intermediação (betweeneess) e autovetor (eigenvector). Vale ressaltar que novamente identificamos o fenômeno do "clique" ao analisar a centralidade de autovetor (eigenvector). Optamos, portanto, por eliminar da tabela 22, os pesquisadores Bruna Viana, Érico Cardoso Porto e Fernanda Vianna Gurjão, pois, embora apresentem maiores medidas que Lamounier Erthal Villela, Jonathan Felix Ribeiro Lopes e William dos Santos Melo, caracterizam-se como pesquisadores one-timers.

Tabela 22: Medidas de centralidade da Rede de Pesquisadores do EnAPG

\begin{tabular}{lc}
\hline \multicolumn{1}{c}{ Pesquisador } & Medida \\
\hline Centralidade de grau (degree) & \\
\hline MARIA CAROLINA MARTINEZ ANDION & 0,02406 \\
FERNANDO GUILHERME TENÓRIO & 0,02139 \\
ANDERSON FELISBERTO DIAS & 0,01872 \\
FERNANDA CRISTINA DA SILVA & 0,01604 \\
LUCIANA FRANCISCO DE ABREU RONCONI & 0,01604 \\
RONISE SUZUKI DE OLIVEIRA & 0,01604 \\
\hline Centralidade de intermediação (betweeneess) & \\
\hline MARIA CAROLINA MARTINEZ ANDION & 0,00049 \\
JOSÉ ROBERTO PEREIRA & 0,00034 \\
FERNANDO GUILHERME TENÓRIO & 0,00026 \\
LUCIANA FRANCISCO DE ABREU RONCONI & 0,00026 \\
ANA CAROLINA GUERRA & 0,00026 \\
\hline Centralidade de autovetor (eigenvector) & \\
\hline FERNANDO GUILHERME TENÓRIO & 0,15456 \\
\hline ANDERSON FELISBERTO DIAS & 0,14989
\end{tabular}




\begin{tabular}{ll} 
LAMOUNIER ERTHAL VILLELA & 0,12808 \\
JONATHAN FELIX RIBEIRO LOPES & 0,06956 \\
WILLIAM DOS SANTOS MELO & 0,06956 \\
\hline
\end{tabular}

Fonte: elaborado pela autora

Figura 14: Representação gráfica da centralidade de grau (degree), centralidade de intermediação (betweenness) e centralidade de autovetor (eigenvector) da Rede de

\section{Pesquisadores do EnAPG}
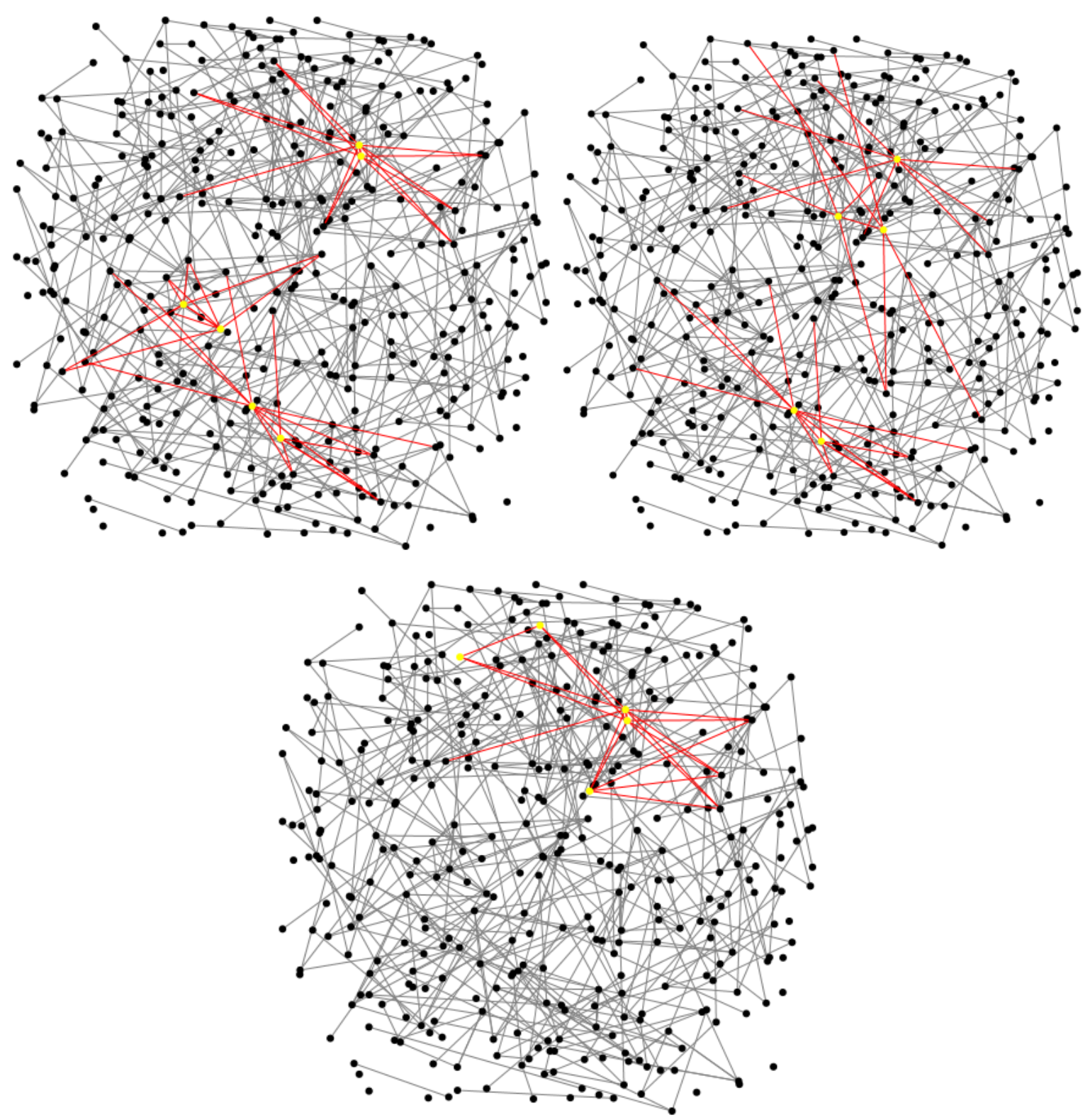

Fonte: elaborado pela autora

Notamos que, dos 14 pesquisadores em destaque na Rede de Pesquisadores do EnAPG, 21,43\% adquiriram sua última titulação acadêmica na Universidade Federal de Santa Catarina (UFSC) e 21,43\% na Fundação Getúlio Vargas (FGV). Também podemos apontar 
que $28,57 \%$ dos pesquisadores cursaram doutorado em universidades estrangeiras (Estados Unidos, França Inglaterra e Portugal). O estado de Santa Catarina destaca-se novamente quando analisamos a vinculação institucional relacionada à atuação profissional dos pesquisadores: 21,43\% atuam na Universidade do Estado de Santa Catarina (UDESC).

\section{Quadro 18: Atributos dos principais autores da Rede de Pesquisadores do EnAPG}

\begin{tabular}{|c|c|c|c|c|c|c|}
\hline \multirow[b]{2}{*}{ Pesquisador(a) } & \multicolumn{4}{|c|}{ Formação acadêmica } & \multicolumn{2}{|c|}{ Atuação profissional } \\
\hline & $\begin{array}{l}\text { Última } \\
\text { titulação }\end{array}$ & Instituição & Área & Subárea & $\begin{array}{c}\text { Vínculo } \\
\text { Institucional }\end{array}$ & Instituiçãa \\
\hline $\begin{array}{l}\text { ANA CAROLINA } \\
\text { GUERRA }\end{array}$ & Doutorado & UFMG & Administração & & Professora & UNIFAL \\
\hline $\begin{array}{l}\text { ANDERSON } \\
\text { FELISBERTO DIAS }\end{array}$ & Doutorado & FGV & Administração & & $\begin{array}{l}\text { Professor / } \\
\text { Bolsista }\end{array}$ & FGV \\
\hline $\begin{array}{l}\text { FERNANDA CRISTINA } \\
\text { DA SILVA }\end{array}$ & Doutorado & FGV & $\begin{array}{l}\text { Administração } \\
\text { Pública e } \\
\text { Governo }\end{array}$ & & Professora & UFV \\
\hline $\begin{array}{l}\text { FERNANDO } \\
\text { GUILHERME TENÓRIO }\end{array}$ & Doutorado & UFRJ & $\begin{array}{l}\text { Engenharia de } \\
\text { Produção }\end{array}$ & & Professor & FGV \\
\hline $\begin{array}{l}\text { JONATHAN FELIX } \\
\text { RIBEIRO LOPES }\end{array}$ & Mestrado & $\begin{array}{l}\text { Universidade } \\
\text { de Lisboa }\end{array}$ & $\begin{array}{l}\text { Administração } \\
\text { Pública }\end{array}$ & & Pesquisador & $\begin{array}{l}\text { Universidade } \\
\text { de Lisboa }\end{array}$ \\
\hline $\begin{array}{l}\text { JOSÉ ANTÔNIO GOMES } \\
\text { DE PINHO }\end{array}$ & Doutorado & $\begin{array}{l}\text { University of } \\
\text { London }\end{array}$ & $\begin{array}{l}\text { Planejamento } \\
\text { Regional }\end{array}$ & & Professor & UFBA \\
\hline JOSÉ FRANCISCO SALM & Doutorado & $\begin{array}{l}\text { University of } \\
\text { Southern } \\
\text { California }\end{array}$ & Administração & $\begin{array}{l}\text { Administração } \\
\text { Pública }\end{array}$ & Professor & UNINTER \\
\hline $\begin{array}{l}\text { JOSÉ ROBERTO } \\
\text { PEREIRA }\end{array}$ & Doutorado & UnB & Sociologia & $\begin{array}{l}\text { Sociologia Rural / } \\
\text { Sociologia do } \\
\text { Desenvolvimento }\end{array}$ & Professor & UFLA \\
\hline $\begin{array}{l}\text { LAMOUNIER ERTHAL } \\
\text { VILLELA }\end{array}$ & Doutorado & $\begin{array}{c}\text { Université } \\
\text { Sorbonne } \\
\text { Nouvelle - } \\
\text { Paris } 3\end{array}$ & Economia & $\begin{array}{c}\text { Crescimento, } \\
\text { Flutuações e } \\
\text { Planejamento } \\
\text { Econômico / } \\
\text { Economia do } \\
\text { Bem-Estar Social }\end{array}$ & Professor & UFRRJ \\
\hline $\begin{array}{l}\text { LUCIANA FRANCISCO } \\
\text { DE ABREU RONCONI }\end{array}$ & Doutorado & UFSC & Sociologia & & Professora & UDESC \\
\hline $\begin{array}{l}\text { MARIA CAROLINA } \\
\text { MARTINEZ ANDION }\end{array}$ & Doutorado & UFSC & $\begin{array}{l}\text { Ciência } \\
\text { Política / } \\
\text { Sociologia }\end{array}$ & & Professora & UDESC \\
\hline $\begin{array}{l}\text { MARIA ESTER } \\
\text { MENEGASSO }\end{array}$ & Doutorado & UFSC & $\begin{array}{l}\text { Engenharia de } \\
\text { Produção }\end{array}$ & $\begin{array}{l}\text { Qualidade e } \\
\text { Produtividade }\end{array}$ & Professora & UDESC \\
\hline
\end{tabular}




\begin{tabular}{|l|l|l|l|l|l|c|}
\hline $\begin{array}{l}\text { RONISE SUZUKI DE } \\
\text { OLIVEIRA }\end{array}$ & Mestrado & UFV & Administração & Professora & $\begin{array}{c}\text { IFSP / } \\
\text { UNIVIÇOSA }\end{array}$ \\
\hline $\begin{array}{l}\text { WILLIAM DOS SANTOS } \\
\text { MELO }\end{array}$ & Mestrado & FGV & $\begin{array}{c}\text { Administração } \\
\text { Pública e } \\
\text { Governo }\end{array}$ & Professor & UFRJ \\
\hline
\end{tabular}

Fonte: elaborado pela autora com base na Plataforma Lattes

Em comparação com a Rede de Pesquisadores de Gestão Social (RPGS), a rede do EnAPG apresenta um número menor de pesquisadores one-timers, 37,92\%, em contraponto a $72,11 \%$. A porcentagem de pesquisadores continuantes do EnAPG é cerca de sete vezes maior do que a proporção da Rede de Pesquisadores de Gestão Social (RPGS), sendo 20,09\% e $2,65 \%$, respectivamente. Em seguida, verificamos que há $23,25 \%$ de pesquisadores retirantes, $16,03 \%$ de pesquisadores transientes e $2,71 \%$ de pesquisadores entrantes. Vale ressaltar o alto número de pesquisadores retirantes e o baixo número de pesquisadores entrantes.

\section{Tabela 23: Categorização dos Pesquisadores da Rede de Pesquisadores do EnAPG}

\begin{tabular}{cc}
\hline Categoria & \% do total de autorias do evento \\
\hline Continuantes & $20,09 \%$ \\
Transientes & $16,03 \%$ \\
One-timers & $37,92 \%$ \\
Entrantes & $2,71 \%$ \\
Retirantes & $23,25 \%$ \\
\hline
\end{tabular}

Fonte: elaborado pela autora

Podemos notar que o EnAPG é um evento típico do campo da Administração da Pública e conta com a presença de pesquisadores deste campo que fazem uma interface com a Gestão Social, como é o caso de José Antônio Gomes de Pinho, que fez uma série de críticas ao campo da Gestão Social (vide Box 2) e de José Francisco Salm e Maria Ester Menegasso, que trabalham a temática do Novo Serviço Público. 


\subsection{Rede de Pesquisadores do EMAPEGS}

O Encontro Mineiro de Administração Pública, Economia Solidária e Gestão Social (EMAPEGS) vem sendo realizado alternadamente pela Universidade Federal de Lavras (UFLA) e Universidade Federal de Viçosa (UFV). Conforme explicitado no capítulo 3, de procedimentos metodológicos, este trabalho considerará apenas a edição realizada no ano de 2015.

A Rede de Pesquisadores do EMAPEGS é composta por 191 vértices e 228 arestas, sendo que 220 são arestas únicas e 8 são arestas duplicadas. Sobre os vértices, apenas 12 pesquisadores apresentaram artigos sem nenhuma coautoria, o que representa $6,28 \%$ do total. A densidade da rede é de 0,0123450 . Na figura 15, podemos notar que há um número razoável de ligações entre os vértices e um pequeno número de vértices sem nenhuma ligação.

\section{Figura 15: Rede de Pesquisadores do EMAPEGS}

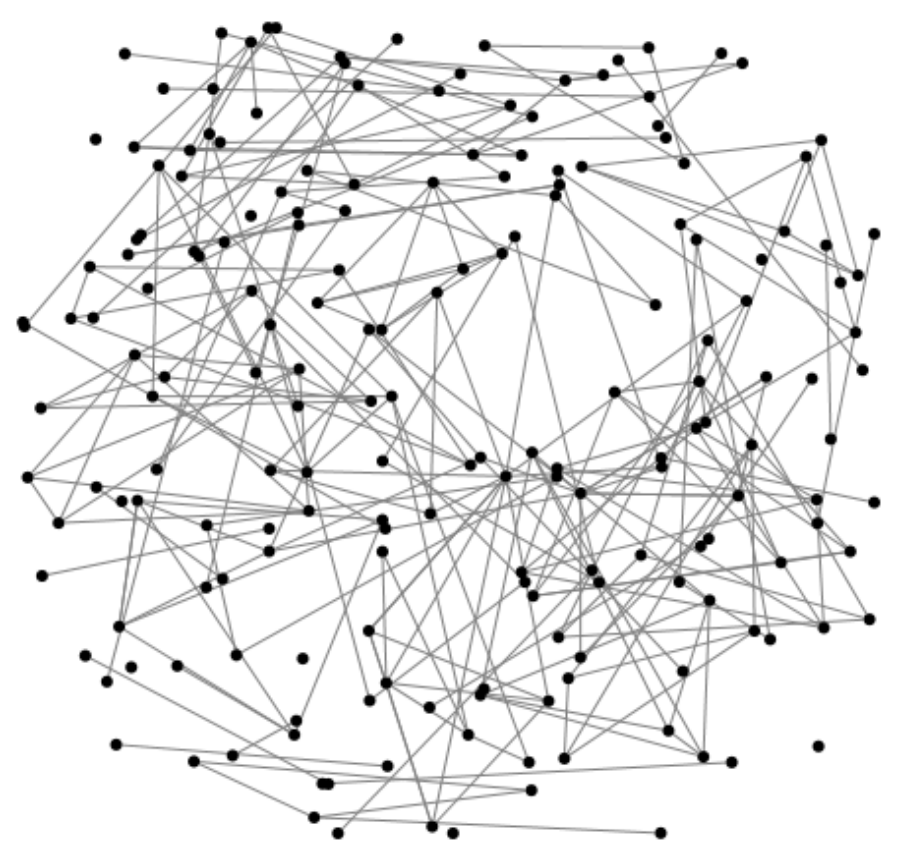

Fonte: elaborado pela autora

A próxima categoria de análise, que aponta os autores mais prolíficos, deve ser vista com cautela, pois, neste caso específico, estamos considerando apenas uma das edições do evento. Com as devidas considerações feitas, vemos que os autores mais prolíficos são: 
Rodrigo Gava, Magnus Luiz Emmendoerfer, Brendow Oliveira Fraga, Edson Arlindo Silva e Maria Júlia Clemente Vecchi, conforme detalha a tabela 24.

Tabela 24: Autores mais prolíficos da Rede de Pesquisadores do EMAPEGS

\begin{tabular}{lc}
\hline \multicolumn{1}{c}{ Pesquisador } & $\mathbf{N}^{\mathbf{0}}$ de publicações \\
\hline RODRIGO GAVA & 6 \\
MAGNUS LUIZ EMMENDOERFER & 5 \\
BRENDOW OLIVEIRA FRAGA & 4 \\
EDSON ARLINDO SILVA & 3 \\
MARIA JÚLIA CLEMENTE VECCHI & 3 \\
\hline
\end{tabular}

Fonte: elaborado pela autora

$\mathrm{Na}$ tabela 25, podemos observar as medidas de centralidade da rede. Além de ser o pesquisador mais prolífico dessa edição do EMAPEGS, verificamos que o pesquisador Rodrigo Gava também apresentou a maior centralidade de grau (degree), de intermediação (betweenness) e de autovetor (eigenvector). O pesquisador Magnus Luiz Emmendoerfer também aparece na lista dos pesquisadores mais prolíficos e com maior centralidade de grau (degree) e intermediação (betweeneess). Embora o pesquisador Bruno Tavares não apareça entre os mais prolíficos, ele consta como um dos pesquisadores com as maiores medidas de centralidade da rede.

Vale destacar que o grupo de pesquisadores apontados com as maiores medidas de centralidade de autovetor (eigenvector) constituem um "clique". Rodrigo Gava, Bruno Tavares e Afonso Augusto Teixeira De Freitas De Carvalho Lima são classificados como pesquisadores continuantes e Cecilia Alves Da Silva Antero e Sabrina Olimpio Caldas de Castro como pesquisadoras entrantes. Dessa forma, não desprezaremos essas medidas e manteremos na análise.

Tabela 25: Medidas de centralidade da Rede de Pesquisadores do EMAPEGS

\begin{tabular}{lc}
\hline \multicolumn{1}{c}{ Pesquisador } & Medida \\
\hline Centralidade de grau (degree) & \\
\hline RODRIGO GAVA & 0,05263 \\
MAGNUS LUIZ EMMENDOERFER & 0,03684 \\
BRUNO TAVARES & 0,03158 \\
ADRIEL RODRIGUES DE OLIVEIRA & 0,02632
\end{tabular}


Centralidade de intermediação (betweeneess)

RODRIGO GAVA

0,01431

MAGNUS LUIZ EMMENDOERFER

0,01356

BRENDOW OLIVEIRA FRAGA

0,01231

BRUNO TAVARES

0,00897

ADRIEL RODRIGUES DE OLIVEIRA

0,00696

JÉSSICA NATÁLIA SILVA

0,00696

Centralidade de autovetor (eigenvector)

RODRIGO GAVA

0,14400

BRUNO TAVARES

0,09800

AFONSO AUGUSTO TEIXEIRA DE FREITAS DE CARVALHO LIMA 0,08800

CECILIA ALVES DA SILVA ANTERO

0,08800

SABRINA OLIMPIO CALDAS DE CASTRO

0,08800

Fonte: elaborado pela autora

Abaixo podemos ver a representação gráfica das três medidas de centralidade citadas acima.

Figura 16: Representação gráfica da centralidade de grau (degree), centralidade de intermediação (betweenness) e centralidade de autovetor (eigenvector) da Rede de Pesquisadores do EMAPEGS

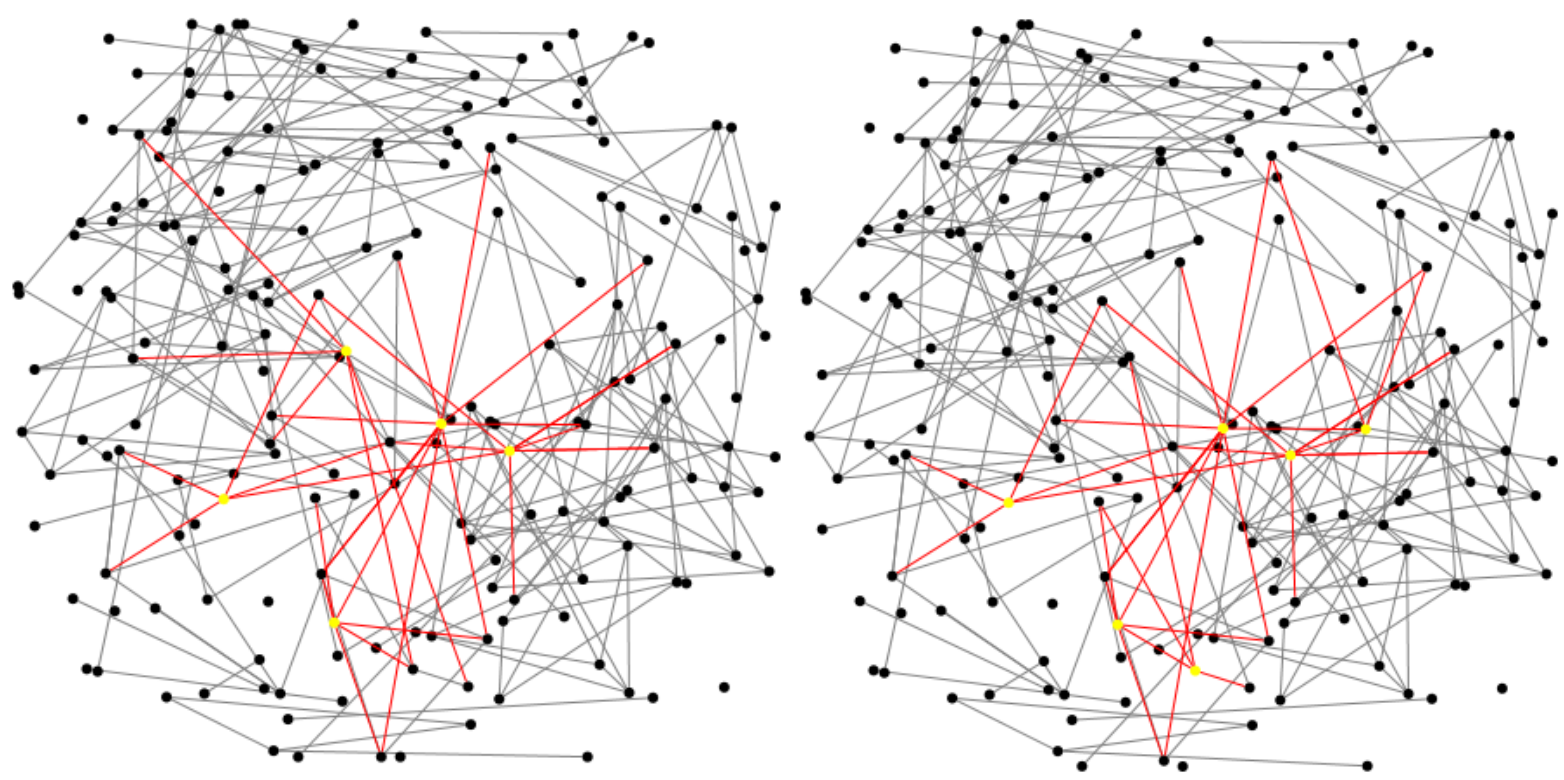




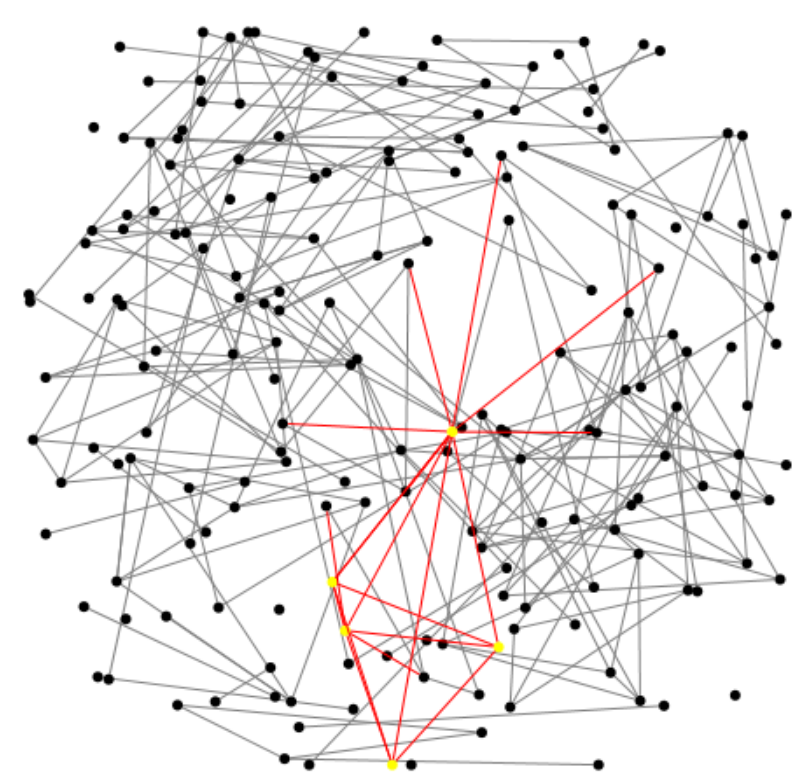

Fonte: elaborado pela autora

Em relação à filiação dos pesquisadores, $50 \%$ adquiriu sua última titulação na Universidade Federal de Viçosa (UFV) e 83,33\% atua profissionalmente na mesma instituição. Novamente, notamos a forte presença das universidades mineiras na formação dos pesquisadores da área de Gestão Social, correspondendo a 75\% do total, ou seja, dos 11 pesquisadores em destaque da rede, 9 deles possuem formação acadêmica por uma das seguintes instituições: Universidade Federal de Lavras, Universidade Federal de Viçosa ou Universidade Federal de Minas Gerais.

Quadro 19: Atributos dos principais autores da Rede de Pesquisadores do EMAPEGS

\begin{tabular}{|l|c|c|c|c|c|c|}
\hline \multirow{2}{*}{ Pesquisador(a) } & \multicolumn{3}{c|}{ Formação acadêmica } & \multicolumn{2}{c|}{ Atuação profissional } \\
\cline { 2 - 7 } & $\begin{array}{c}\text { Última } \\
\text { titulação }\end{array}$ & Instituição & Área & Subárea & $\begin{array}{c}\text { Vínculo } \\
\text { Institucional }\end{array}$ & Instituição \\
\hline $\begin{array}{l}\text { ADRIEL RODRIGUES DE } \\
\text { OLIVEIRA }\end{array}$ & Doutorado & USP & Administração & Professor & UFV \\
\hline $\begin{array}{l}\text { AFONSO AUGUSTO } \\
\text { TEIXEIRA DE FREITAS } \\
\text { DE CARVALHO LIMA }\end{array}$ & Doutorado & UFSC & $\begin{array}{c}\text { Engenharia de } \\
\text { Produção }\end{array}$ & & Professor & UFV \\
\hline $\begin{array}{l}\text { BRENDOW OLIVEIRA } \\
\text { FRAGA }\end{array}$ & Graduação & UFV & Administração & Bolsista & UFV \\
\hline $\begin{array}{l}\text { BRUNO TAVARES } \\
\text { BRAR }\end{array}$ & Doutorado & UFLA & Administração & $\begin{array}{c}\text { Administração de } \\
\text { Empresas }\end{array}$ & Professor & UFV \\
\hline
\end{tabular}




\begin{tabular}{|c|c|c|c|c|c|c|}
\hline $\begin{array}{l}\text { CECILIA ALVES DA } \\
\text { SILVA ANTERO }\end{array}$ & Mestrado & UFV & Administração & & $\begin{array}{l}\text { Professora / } \\
\text { Tutora }\end{array}$ & $\begin{array}{l}\text { FADIP / } \\
\text { UFV }\end{array}$ \\
\hline EDSON ARLINDO SILVA & Doutorado & UFLA & Administração & & Professor & UFV \\
\hline $\begin{array}{l}\text { JÉSSICA NATÁLIA } \\
\text { SILVA }\end{array}$ & Graduação & UFV & Administração & & $\begin{array}{c}\text { Auxiliar } \\
\text { Administrativa }\end{array}$ & $\begin{array}{c}\text { Agros } \\
\text { Instituto } \\
\text { UFV de } \\
\text { Seguridade } \\
\text { Social } \\
\end{array}$ \\
\hline $\begin{array}{l}\text { MAGNUS LUIZ } \\
\text { EMMENDOERFER }\end{array}$ & Doutorado & UFMG & $\begin{array}{c}\text { Sociologia / } \\
\text { Administração }\end{array}$ & $\begin{array}{c}\text { Sociologia } \\
\text { Econômica e das } \\
\text { Organizações / } \\
\text { Administração de } \\
\text { Empresas } \\
\end{array}$ & Professor & UFV \\
\hline $\begin{array}{l}\text { MARIA JÚLIA } \\
\text { CLEMENTE VECCHI }\end{array}$ & Graduação & UFV & Administração & & Bolsista & UFV \\
\hline $\begin{array}{l}\text { MYRIAM MARTA } \\
\text { MELLO }\end{array}$ & Graduação & UFV & $\begin{array}{l}\text { Ciências } \\
\text { Contábeis }\end{array}$ & & & \\
\hline RODRIGO GAVA & Doutorado & FGV & Administração & & Professor & UFV \\
\hline $\begin{array}{l}\text { SABRINA OLIMPIO } \\
\text { CALDAS DE CASTRO }\end{array}$ & Graduação & UFV & Administração & & Bolsista & UFV \\
\hline
\end{tabular}

Fonte: elaborado pela autora com base na Plataforma Lattes

A análise da rede do ponto de vista da categorização dos pesquisadores, segundo sua regularidade de produção científica, apresenta um resultado interessante. Em comparação com a Rede de Pesquisadores de Gestão Social (RPGS), o número de continuantes e entrantes da Rede de Pesquisadores do EMAPEGS é bastante superior, correspondendo a $14,72 \%$ e 25,97\%, respectivamente, em contraponto aos 2,65\% e 3,49\% da Rede de Pesquisadores de Gestão Social (RPGS). 
Tabela 26: Categorização dos Pesquisadores da Rede de Pesquisadores do EMAPEGS

\begin{tabular}{cc}
\hline Categoria & \% do total de autorias do evento \\
\hline Continuantes & $14,72 \%$ \\
Transientes & $7,36 \%$ \\
One-timers & $51,95 \%$ \\
Entrantes & $25,97 \%$ \\
Retirantes & $0,00 \%$ \\
\hline \multicolumn{2}{c}{ Fonte: elaborado pela autora } \\
\hline
\end{tabular}

Diante desses dados, podemos concluir que o EMAPEGS é um evento típico da área da Gestão Social, pois os pesquisadores se identificam com as temáticas e submetem seus trabalhos. Outro fator que deve ser observado é a regionalização do evento que contou prioritariamente com pesquisadores ligados a instituições da região de Minas Gerais.

\subsection{Rede de Pesquisadores da Revista de Administração Pública (RAP)}

A Revista de Administração Pública (RAP) foi fundada em 1967, no âmbito da Fundação Getúlio Vargas. Para fins desta pesquisa, analisamos 52 números do período, entre 2005 e 2015.

A Rede de Pesquisadores da Revista de Administração Pública (RAP) é composta por 290 pesquisadores (vértices) e 289 ligações (arestas) entre os pesquisadores, sendo que 275 ligações são únicas e 14 são duplicadas. Do total de 290 pesquisadores, 10,69\% deles publicaram apenas artigos sem coautoria. A densidade da rede é de 0,006729507. 
Figura 17: Rede de Pesquisadores da Revista de Administração Pública (RAP)

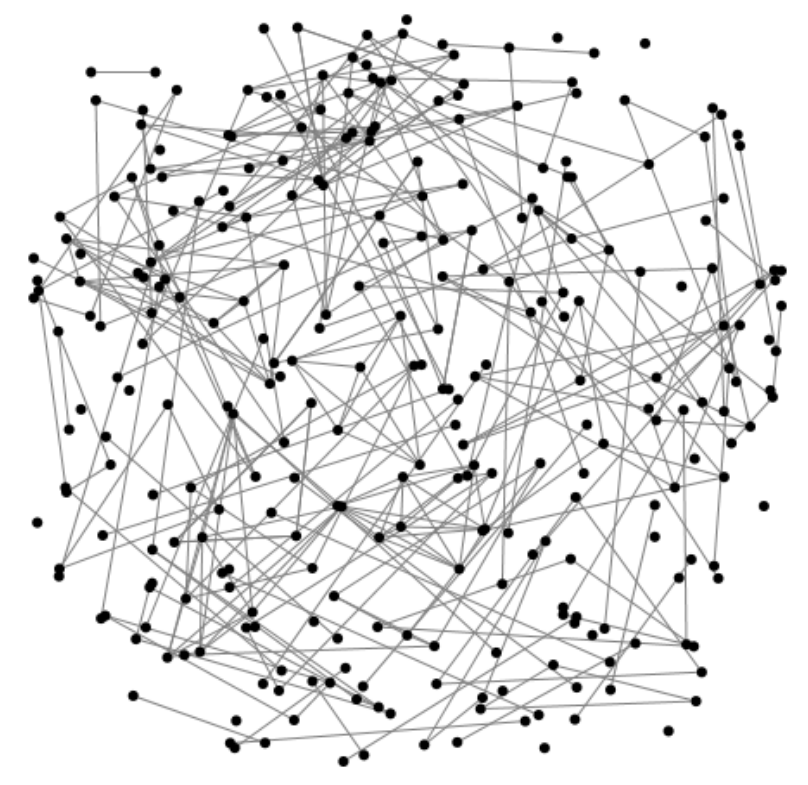

Fonte: elaborado pela autora

O pesquisador mais prolífico da Rede de Pesquisadores da Revista de Administração Pública (RAP) é Luciano Antonio Prates Junqueira, com 3 publicações no período analisado. Em segundo lugar há 21 pesquisadores empatados com 2 publicações cada um. Portanto, optamos por apontar apenas o pesquisador com o maior número de publicações.

Tabela 27: Autores mais prolíficos da Rede de Pesquisadores da Revista de Administração Pública (RAP)

\begin{tabular}{cc}
\hline Pesquisador & $\mathbf{N}^{\mathbf{o}}$ de publicações \\
\hline LUCIANO ANTONIO PRATES JUNQUEIRA & 3 \\
\hline Fonte: elaborado pela autora &
\end{tabular}

Fonte: elaborado pela autora

Os autores com as maiores medidas de centralidade de grau (degree) foram desprezados, pois todos se classificavam como pesquisadores one-timers. Apresentamos na tabela 28 os pesquisadores com a segunda maior medida de centralidade de grau (degree), excluindo novamente os pesquisadores one-timers. O cálculo das medidas de centralidade de intermediação (betweeneess) resultou nos seguintes pesquisadores com as maiores medidas: Luciano Antonio Prates Junqueira, Sylmara Lopes Francelino Gonçalves-Dias, Anny Karine de Medeiros, Mário Aquino Alves e José Osvaldo de Sordi. Por fim, devemos ressaltar que 
não apontaremos os pesquisadores com as maiores medidas de centralidade de autovetor (eigenvector), pois todos que apresentaram algum valor eram one-timers.

Tabela 28: Medidas de centralidade da Rede de Pesquisadores da Revista de Administração Pública (RAP)

\begin{tabular}{lc}
\hline \multicolumn{1}{c}{ Pesquisador } & Medida \\
\hline Centralidade de grau (degree) & \\
\hline ADEMÁRIO DE JESUS & 0,01730 \\
ANDREA PAULA SEGATTO & 0,01730 \\
CARLOS CESAR GARCIA FREITAS & 0,01730 \\
CLAUDIANI WAIANDT & 0,01730 \\
MARCOS ROBERTO KUHL & 0,01730 \\
MARLETE BEATRIZ MAÇANEIRO & 0,01730 \\
MÉRCYA ROSE DE OLIVEIRA CARVALHO & 0,01730 \\
TÂNIA MARIA DIEDERICHS FISCHER & 0,01730 \\
VANESSA PATERNOSTRO MELO & 0,01730 \\
\hline Centralidade de intermediação (betweeneess) & 0,00022 \\
\hline LUCIANO ANTONIO PRATES JUNQUEIRA & 0,00019 \\
SYLMARA LOPES FRANCELINO GONÇALVES-DIAS & 0,00014 \\
ANNY KARINE DE MEDEIROS & 0,00010 \\
MÁRIO AQUINO ALVES & 0,00007 \\
\hline JOSÉ OSVALDO DE SORDI &
\end{tabular}


Figura 18: Representação gráfica da centralidade de grau (degree) e centralidade de intermediação (betweenness) da Rede de Pesquisadores da Revista de Administração Pública (RAP)
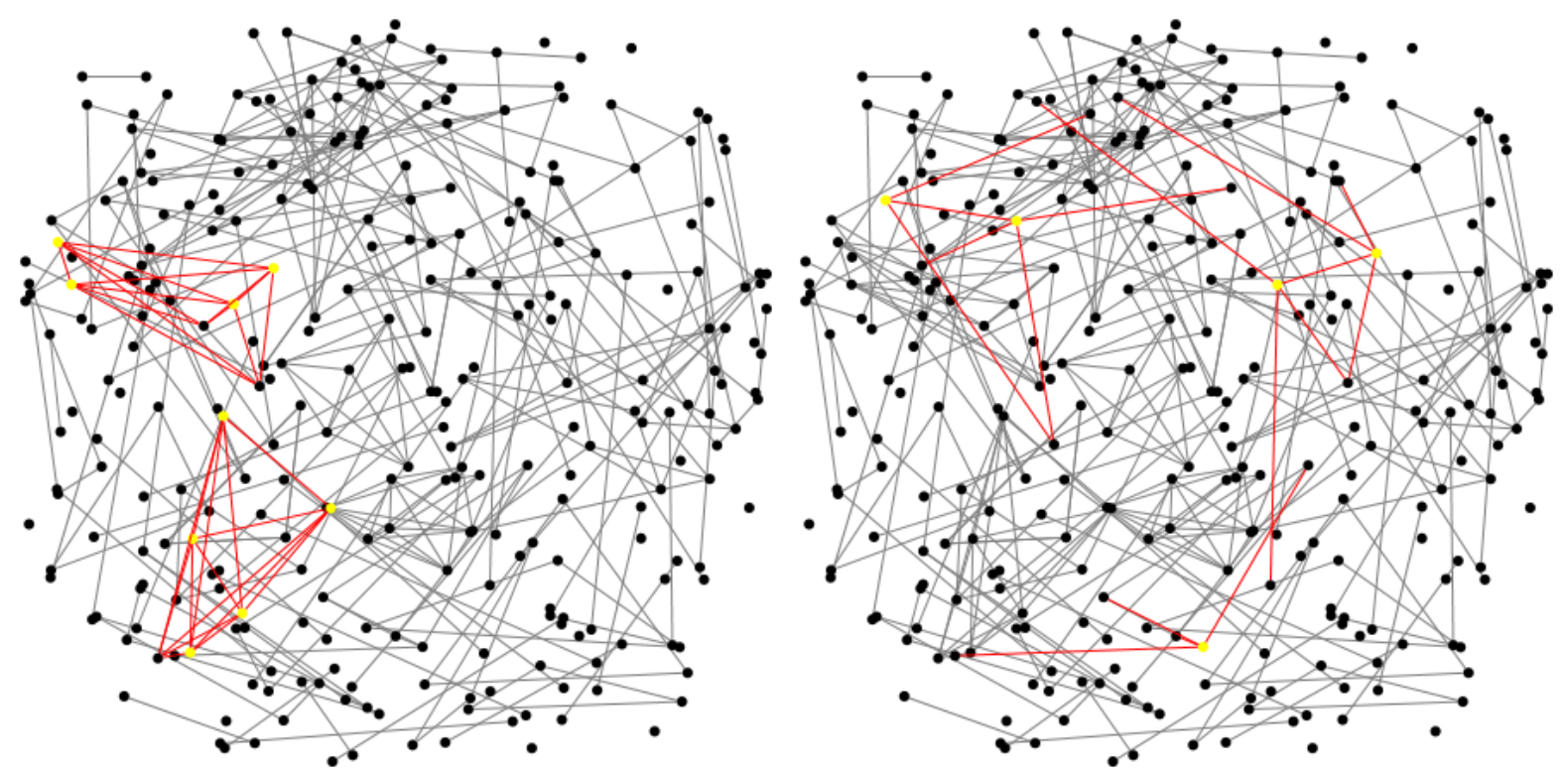

Fonte: elaborado pela autora

Os principais pesquisadores da Rede de Pesquisadores da Revista de Administração Pública (RAP) adquiriram sua última titulação acadêmica em quatro instituições, a saber: Universidade Federal da Bahia, Universidade Federal do Paraná, Universidade de São Paulo e Fundação Getúlio Vargas/SP. No entanto, ao analisar a vinculação institucional da atuação profissional, notamos um número muito maior de instituições, sendo que 14,29\% dos pesquisadores estão ligados à Universidade Estadual do Centro-Oeste (Paraná) e 14,29\% estão ligados à Universidade Federal da Bahia.

Quadro 20: Atributos dos principais autores da Rede de Pesquisadores da Revista de Administração Pública (RAP)

\begin{tabular}{|l|c|c|c|c|c|c|}
\hline \multirow{2}{*}{ Pesquisador(a) } & \multicolumn{3}{|c|}{ Formação acadêmica } & \multicolumn{2}{c|}{ Atuação profissional } \\
\cline { 2 - 7 } & $\begin{array}{c}\text { Última } \\
\text { titulação }\end{array}$ & Instituição & Área & Subárea & $\begin{array}{c}\text { Vínculo } \\
\text { Institucional }\end{array}$ & Instituição \\
\hline ADEMÁRIO DE JESUS & Mestrado & UFBA & Administração & $\begin{array}{c}\text { Administração } \\
\text { Pública }\end{array}$ & $\begin{array}{c}\text { Coordenador de } \\
\text { Inovação }\end{array}$ & FAPESB \\
\hline $\begin{array}{l}\text { ANDREA PAULA } \\
\text { SEGATTO }\end{array}$ & Doutorado & USP & Administração & $\begin{array}{c}\text { Administração de } \\
\text { Ciência e } \\
\text { Tecnologia }\end{array}$ & Professor & UFPR \\
\hline
\end{tabular}




\begin{tabular}{|c|c|c|c|c|c|c|}
\hline $\begin{array}{l}\text { ANNY KARINE DE } \\
\text { MEDEIROS }\end{array}$ & Mestrado & FGV/SP & $\begin{array}{c}\text { Administração } \\
\text { Pública e } \\
\text { Governo }\end{array}$ & & $\begin{array}{c}\text { Gerente de } \\
\text { acompanhamento }\end{array}$ & $\begin{array}{c}\text { Secretaria } \\
\text { Municipal de } \\
\text { Planejamento } \\
\text { e Gestão - } \\
\text { Osasco }\end{array}$ \\
\hline $\begin{array}{l}\text { CARLOS CESAR } \\
\text { GARCIA FREITAS }\end{array}$ & Doutorado & UFPR & Administração & & Professor & UENP \\
\hline CLAUDIANI WAIANDT & Doutorado & UFBA & Administração & Ensino & Professora & UFBA \\
\hline $\begin{array}{l}\text { JOSÉ OSVALDO DE } \\
\text { SORDI }\end{array}$ & Doutorado & $\mathrm{FGV} / \mathrm{SP}$ & $\begin{array}{l}\text { Administração } \\
\text { de Empresas }\end{array}$ & & Professor & $\begin{array}{c}\text { FMU / } \\
\text { FACCAMP }\end{array}$ \\
\hline $\begin{array}{l}\text { LUCIANO ANTONIO } \\
\text { PRATES JUNQUEIRA }\end{array}$ & Doutorado & USP & Administração & $\begin{array}{l}\text { Administração } \\
\text { Pública }\end{array}$ & Professor & PUC/SP \\
\hline $\begin{array}{l}\text { MARCOS ROBERTO } \\
\text { KUHL }\end{array}$ & Doutorado & UFPR & Administração & $\begin{array}{l}\text { Administração de } \\
\text { Empresas }\end{array}$ & Professor & UNICENTRO \\
\hline $\begin{array}{l}\text { MÁRIO AQUINO } \\
\text { ALVES }\end{array}$ & Doutorado & $\mathrm{FGV} / \mathrm{SP}$ & Administração & $\begin{array}{l}\text { Administração } \\
\text { Pública }\end{array}$ & Professor & FGV/SP \\
\hline $\begin{array}{l}\text { MARLETE BEATRIZ } \\
\text { MAÇANEIRO }\end{array}$ & Doutorado & UFPR & Administração & $\begin{array}{l}\text { Tecnologia e } \\
\text { Inovação }\end{array}$ & Professor & UNICENTRO \\
\hline $\begin{array}{l}\text { MÉRCYA ROSE DE } \\
\text { OLIVEIRA CARVALHO }\end{array}$ & Mestrado & UFBA & Administração & & Professora & $\begin{array}{l}\text { UNIJORGE / } \\
\text { FDJ }\end{array}$ \\
\hline $\begin{array}{l}\text { SYLMARA LOPES } \\
\text { FRANCELINO } \\
\text { GONÇALVES-DIAS }\end{array}$ & Doutorado & $\begin{array}{l}\text { USP / } \\
\text { FGV/SP }\end{array}$ & Administração & $\begin{array}{l}\text { Administração de } \\
\text { Empresas / } \\
\text { Administração e } \\
\text { meio ambiente }\end{array}$ & Professora & USP \\
\hline $\begin{array}{l}\text { TÂNIA MARIA } \\
\text { DIEDERICHS FISCHER }\end{array}$ & Doutorado & USP & Administração & & Professora & UFBA \\
\hline $\begin{array}{l}\text { VANESSA } \\
\text { PATERNOSTRO MELO }\end{array}$ & Mestrado & UFBA & Educação & $\begin{array}{c}\text { Planejamento e } \\
\text { Avaliação } \\
\text { Educacional }\end{array}$ & Analista & Banco Central \\
\hline
\end{tabular}

Fonte: elaborado pela autora com base na Plataforma Lattes

Seguindo a tendência da maioria das redes analisadas, a maior parte $(43,77 \%)$ dos pesquisadores da Rede de Pesquisadores da Revista de Administração Pública (RAP) é composta por one-timers, seguida por $19,49 \%$ de retirantes, $19,17 \%$ de transientes, $15,02 \%$ de continuantes e $2,56 \%$ de entrantes. 


\section{Tabela 29: Categorização dos Pesquisadores da Rede de Pesquisadores da Revista de Administração Pública (RAP)}

\begin{tabular}{cc}
\hline Categoria & $\begin{array}{c}\text { \% do total de autorias do } \\
\text { periódico }\end{array}$ \\
\hline Continuantes & $15,02 \%$ \\
Transientes & $19,17 \%$ \\
One-timers & $43,77 \%$ \\
Entrantes & $2,56 \%$ \\
Retirantes & $19,49 \%$ \\
\hline \multicolumn{2}{c}{ Fonte: elaborado pela autora } \\
\hline
\end{tabular}

A Revista de Administração Pública (RAP) é o principal periódico de Administração Pública no Brasil atualmente, possuindo alta classificação no sistema Qualis Capes e alto fator de impacto. Portanto, é um periódico muito competitivo e com nível de dificuldade de publicação maior. Apesar dos fatores ponderados, notamos a presença de alguns pesquisadores tradicionais do campo da Gestão Social, como por exemplo: Luciano Antonio Prates Junqueira, Sylmara Lopes Francelino Gonçalves-Dias e Tânia Maria Diederichs Fischer.

\subsection{Rede de Pesquisadores dos Cadernos EBAPE.BR}

Os Cadernos EBAPE.BR, publicados pela primeira vez em 2003, é um periódico online, patrocinado pela Escola Brasileira de Administração Pública e de Empresas da Fundação Getúlio Vargas. De 2003 a 2015, foram publicados 55 números do periódico.

A Rede de Pesquisadores dos Cadernos EBAPE.BR, durante o período considerado nesta pesquisa, possui 189 pesquisadores (vértices) e 199 ligações (arestas), sendo 174 delas únicas e 25 duplicadas. Do total de pesquisadores, 8,99\% optaram por publicar apenas artigos sem coautoria. A densidade da rede é de 0,0104694. 
Figura 19: Rede de Pesquisadores dos Cadernos EBAPE.BR

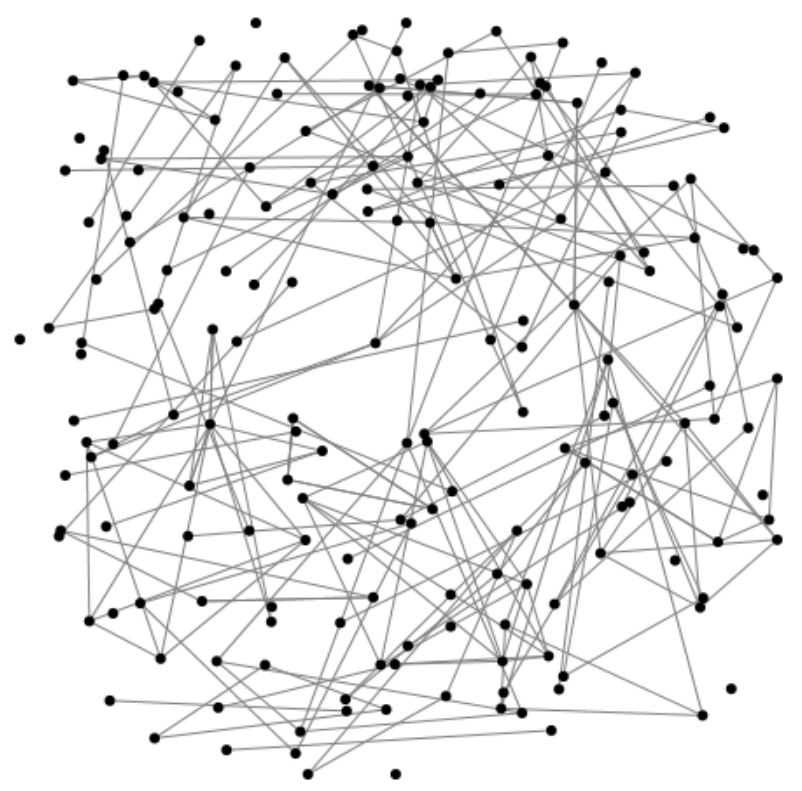

Fonte: elaborado pela autora

Os pesquisadores mais prolíficos da Rede de Pesquisadores dos Cadernos EBAPE.BR são: José Roberto Pereira, com 5 publicações, e Ana Sílvia Rocha Ipiranga, Carlos Eduardo Justen, Jorge Oneide Sausen, Júlio Araújo Carneiro da Cunha e Luís Moretto Neto, com 3 publicações cada.

Tabela 30: Autores mais prolíficos da Rede de Pesquisadores dos Cadernos EBAPE.BR

\begin{tabular}{lc}
\hline \multicolumn{1}{c}{ Pesquisador } & $\mathbf{N}^{\mathbf{0}}$ de publicações \\
\hline JOSÉ ROBERTO PEREIRA & 5 \\
ANA SÍLVIA ROCHA IPIRANGA & 3 \\
CARLOS EDUARDO JUSTEN & 3 \\
JORGE ONEIDE SAUSEN & 3 \\
JÚLIO ARAÚJO CARNEIRO DA CUNHA & 3 \\
LUÍS MORETTO NETO & 3 \\
\hline
\end{tabular}

Fonte: elaborado pela autora

O pesquisador José Roberto Pereira, além de ser o pesquisador mais prolífico da rede, também possui as maiores medidas de centralidade de grau (degree) e de intermediação (betweeneess). Optamos por apontar apenas dois pesquisadores na lista de centralidade de grau (degree), pois em terceiro lugar estão empatados 9 pesquisadores com a medida de 
0,02660. Na lista de centralidade de autovetor (eigenvector), excluímos os pesquisadores Francisco Tiago Garcia Peña e Tatiane Amanda Simm, pois ambos são classificados como one-timers.

Tabela 31: Medidas de centralidade da Rede de Pesquisadores dos Cadernos EBAPE.BR

\begin{tabular}{|c|c|}
\hline Pesquisador & Medida \\
\hline \multicolumn{2}{|l|}{ Centralidade de grau (degree) } \\
\hline JOSÉ ROBERTO PEREIRA & 0,04787 \\
\hline JÚLIO ARAÚJO CARNEIRO DA CUNHA & 0,03191 \\
\hline \multicolumn{2}{|l|}{ Centralidade de intermediação (betweeneess) } \\
\hline JOSÉ ROBERTO PEREIRA & 0,00185 \\
\hline SUELI MARIA GOULART SILVA & 0,00051 \\
\hline FERNANDO GUILHERME TENÓRIO & 0,00051 \\
\hline JÚLIO ARAÚJO CARNEIRO DA CUNHA & 0,00046 \\
\hline ANA SÍLVIA ROCHA IPIRANGA & 0,00034 \\
\hline \multicolumn{2}{|l|}{ Centralidade de autovetor (eigenvector) } \\
\hline CLERILEI APARECIDA BIER & 0,16667 \\
\hline LEANDRO COSTA SCHMITZ & 0,16667 \\
\hline RODRIGO BOUSFIELD & 0,16667 \\
\hline SIMONE GHISI FEUERSCHÜTTE & 0,16667 \\
\hline
\end{tabular}

Fonte: elaborado pela autora

Figura 20: Representação gráfica da centralidade de grau (degree), centralidade de intermediação (betweenness) e centralidade de autovetor (eigenvector) da Rede de Pesquisadores dos Cadernos EBAPE.BR
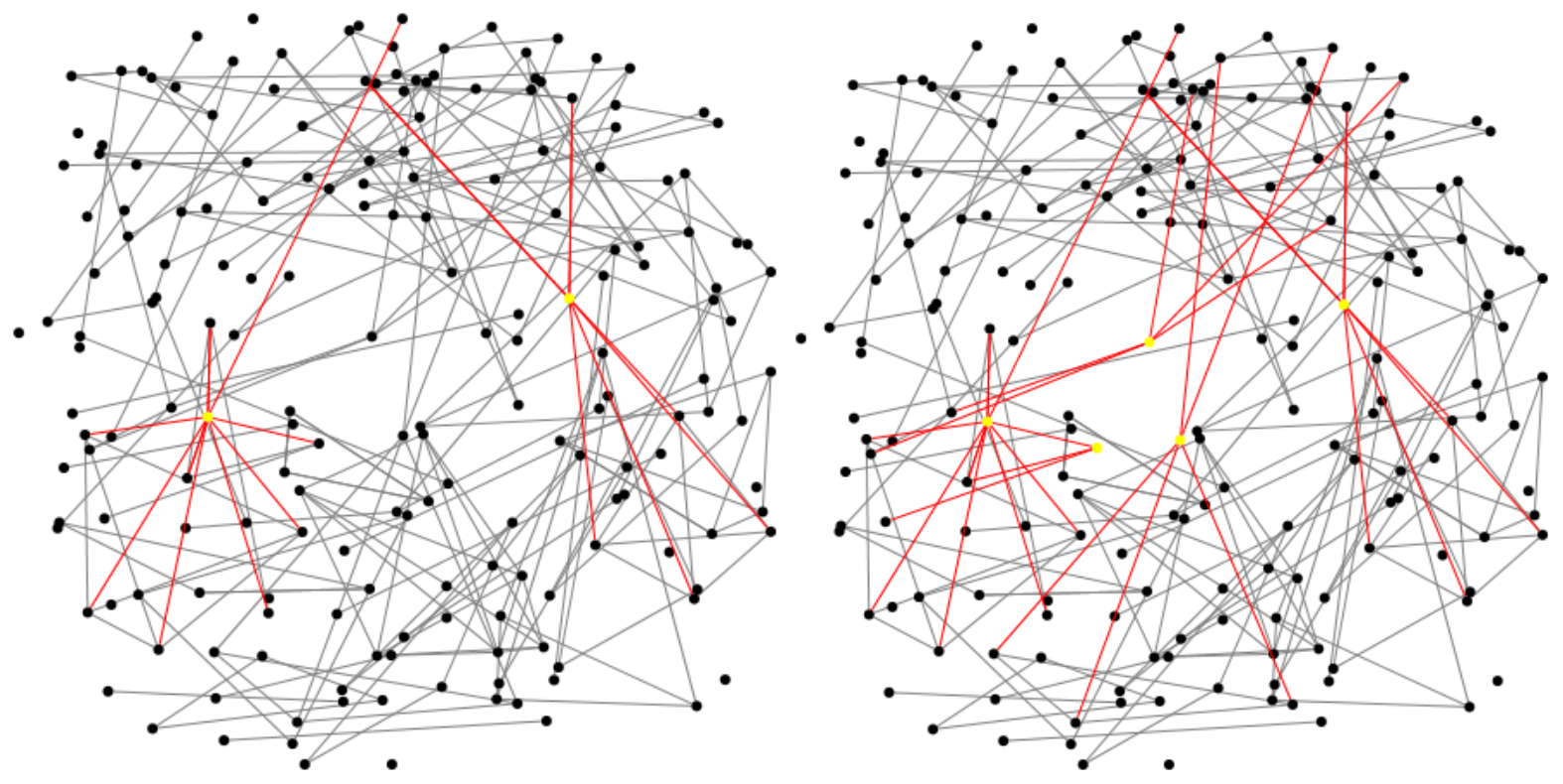


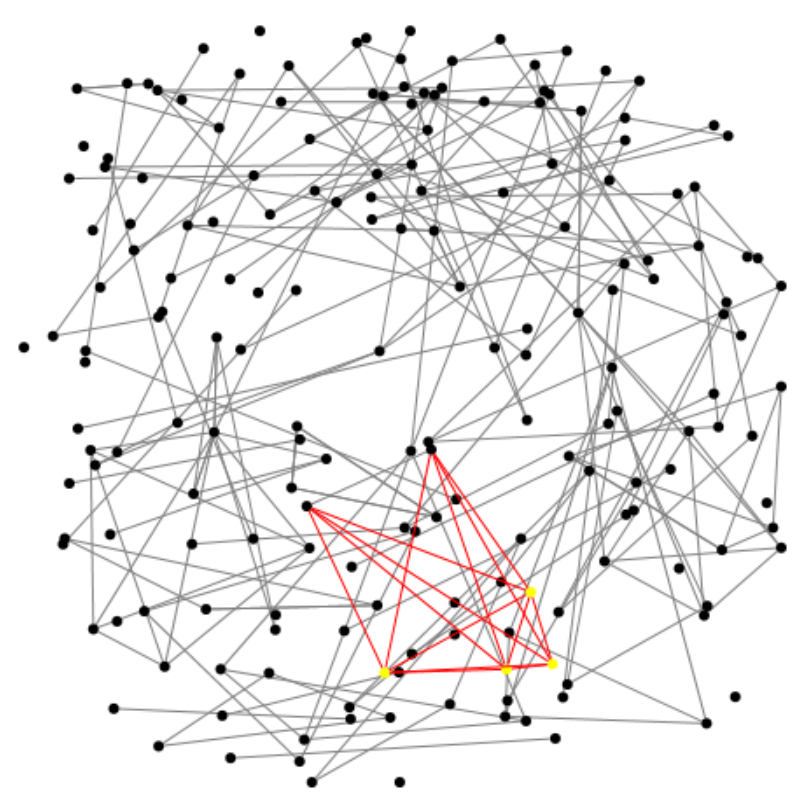

Fonte: elaborado pela autora

Analisando a formação acadêmica dos principais pesquisadores da Rede dos Cadernos EBAPE.BR, notamos que 33,33\% adquiriram titulação de doutorado na Universidade Federal de Santa Catarina (UFSC). A preponderância do estado de Santa Catarina é percebida, novamente, quando verificamos a vinculação institucional da atuação profisssional, pois 44,44\% dos pesquisadores estão ligados à Universidade do Estado de Santa Catarina (UDESC).

\section{Quadro 21: Atributos dos principais autores da Rede de Pesquisadores dos Cadernos EBAPE.BR}

\begin{tabular}{|l|c|c|c|c|c|c|}
\hline \multirow{2}{*}{ Pesquisador(a) } & \multicolumn{3}{|c|}{ Formação acadêmica } & \multicolumn{2}{c|}{ Atuação profissional } \\
\cline { 2 - 7 } & $\begin{array}{c}\text { Última } \\
\text { titulação }\end{array}$ & Instituição & Área & Subárea & $\begin{array}{c}\text { Vínculo } \\
\text { Institucional }\end{array}$ & Instituição \\
\hline $\begin{array}{l}\text { ANA SÍLVIA ROCHA } \\
\text { IPIRANGA }\end{array}$ & Doutorado & $\begin{array}{c}\text { Universita di } \\
\text { Bologna }\end{array}$ & $\begin{array}{c}\text { Ciência } \\
\text { Política / } \\
\text { Psicologia }\end{array}$ & $\begin{array}{c}\text { Comportamento } \\
\text { Político / } \\
\text { Psicologia Social }\end{array}$ & Professora & UECE \\
\hline $\begin{array}{l}\text { CLERILEI APARECIDA } \\
\text { BIER }\end{array}$ & Doutorado & $\begin{array}{c}\text { Universidad } \\
\text { Complutense } \\
\text { de Madrid }\end{array}$ & Direito & Professora & UDESC \\
\hline $\begin{array}{l}\text { FERNANDO } \\
\text { GUILHERME TENÓRIO }\end{array}$ & Doutorado & UFRJ & $\begin{array}{c}\text { Engenharia de } \\
\text { Produção }\end{array}$ & Professor & FGV \\
\hline $\begin{array}{l}\text { JOSÉ ROBERTO } \\
\text { PEREIRA }\end{array}$ & Doutorado & UnB & Sociologia & $\begin{array}{c}\text { Sociologia Rural/ / } \\
\text { Seciogia do }\end{array}$ & Professor & UFLA \\
\hline $\begin{array}{l}\text { JÚLIO ARAÚmento } \\
\text { CARNEIRO DA CUNHA }\end{array}$ & Doutorado & USP / FGV & $\begin{array}{c}\text { Administração } \\
\text { de Empresas }\end{array}$ & & Professor & UNINOVE \\
\hline $\begin{array}{l}\text { LEANDRO COSTA } \\
\text { SCHMITZ }\end{array}$ & Doutorado & UFSC & Administração & Professor & UDESC \\
\hline
\end{tabular}




\begin{tabular}{|l|c|c|c|c|c|c|}
\hline RODRIGO BOUSFIELD & Doutorado & UFSC & Direito & Direito Público & Professor & UDESC \\
\hline $\begin{array}{l}\text { SIMONE GHISI } \\
\text { FEUERSCHÜTTE }\end{array}$ & Doutorado & UFSC & $\begin{array}{c}\text { Engenharia de } \\
\text { Produção }\end{array}$ & Professora & UDESC \\
\hline $\begin{array}{l}\text { SUELI MARIA GOULART } \\
\text { SILVA }\end{array}$ & Doutorado & UFPE & Administração & $\begin{array}{c}\text { Administração de } \\
\text { Setores Específicos }\end{array}$ & Professora & UFRGS \\
\hline
\end{tabular}

Fonte: elaborado pela autora com base na Plataforma Lattes

Assim como a maior parte das redes analisadas, a maior parcela de pesquisadores da Rede de Pesquisadores dos Cadernos EBAPE.BR pertence à categoria de one-timers, representando $32,27 \%$ do total. Na sequência, temos $26,36 \%$ de continuantes, $24,09 \%$ de retirantes, $16,82 \%$ de transientes e apenas $0,45 \%$ de entrantes.

Tabela 32: Categorização dos Pesquisadores da Rede de Pesquisadores dos Cadernos EBAPE.BR

\begin{tabular}{cc}
\hline Categoria & $\begin{array}{c}\text { \% do total de autorias do } \\
\text { periódico }\end{array}$ \\
\hline Continuantes & $26,36 \%$ \\
Transientes & $16,82 \%$ \\
One-timers & $32,27 \%$ \\
Entrantes & $0,45 \%$ \\
Retirantes & $24,09 \%$ \\
\hline \multicolumn{2}{c}{ Fonte: elaborado pela autora } \\
\hline
\end{tabular}

É possível notar que entre os pesquisadores mais prolíficos há a predominância de pesquisadores que atuam no campo dos estudos organizacionais críticos, como é o caso de Ana Sílvia Rocha Ipiranga, Jorge Oneide Sausen e Júlio Araújo Carneiro da Cunha. 


\subsection{Rede de Pesquisadores da Revista Organizações \& Sociedade (O\&S)}

A Revista Organizações \& Sociedade (O\&S), fundada em 1993, é uma publicação da Escola de Administração da Universidade Federal da Bahia (UFBA). Considerando o período analisado por esta pesquisa, selecionamos 33 números publicados.

A Rede de Pesquisadores da Revista Organizações \& Sociedade (O\&S) possui 148 pesquisadores (vértices) e 142 ligações (arestas) entre os pesquisadores, sendo que todas as ligações são únicas. Do total de pesquisadores, 8,78\% publicou apenas artigos sem coautoria. A densidade da rede é de 0,0130539.

Figura 21: Rede de Pesquisadores da Revista Organizações \& Sociedade (O\&S)

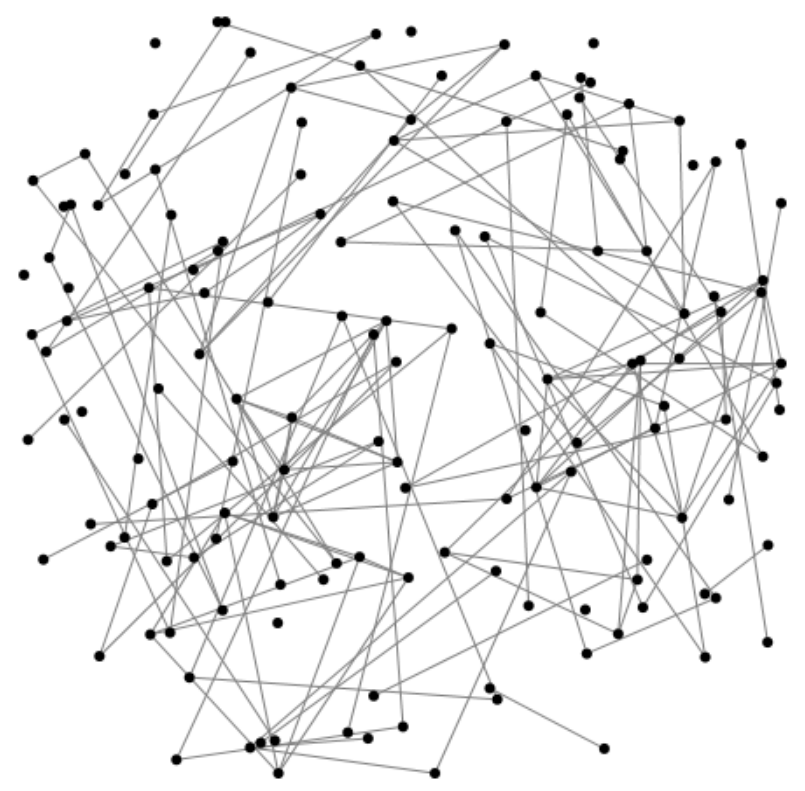

Fonte: elaborado pela autora

Os pesquisadores mais prolíficos da Rede de Pesquisadores da Revista Organizações \& Sociedade $(\mathrm{O} \& S)$ são: Deise Luiza da Silva Ferraz, com 3 publicações, Andréa Leite Rodrigues, Genauto Carvalho de França Filho, Júlia Furlanetto Graeff, Luciana Mourão, Luciano Munck, Maria Vilma Coelho Moreira e Sergio Bulgacov, com 2 publicações cada um. 
Tabela 33: Autores mais prolíficos da Rede de Pesquisadores da Revista Organizações \& Sociedade (O\&S)

\begin{tabular}{lc}
\hline \multicolumn{1}{c}{ Pesquisador } & $\mathbf{N}^{\mathbf{o}}$ de publicações \\
\hline DEISE LUIZA DA SILVA FERRAZ & 3 \\
ANDRÉA LEITE RODRIGUES & 2 \\
GENAUTO CARVALHO DE FRANÇA FILHO & 2 \\
JÚLIA FURLANETTO GRAEFF & 2 \\
LUCIANA MOURÃO & 2 \\
LUCIANO MUNCK & 2 \\
MARIA VILMA COELHO MOREIRA & 2 \\
SERGIO BULGACOV & 2 \\
\hline
\end{tabular}

Fonte: elaborado pela autora

$\mathrm{Na}$ análise das medidas de centralidade de grau (degree), de intermediação (betweeneess) e de autovetor (eigenvector), optamos por não incluir os pesquisadores onetimers na tabela 34. Outro ponto que devemos destacar é que todos os pesquisadores apresentados na tabela 34 obtiveram o mesmo resultado, ou seja, todos os pesquisadores apresentaram uma medida de centralidade de grau (degree) igual a 0,03401. O mesmo ocorreu com as medidas de centralidade de intermediação (betweeneess), que é de 0,00019, e da centralidade de autovetor (eigenvector), igual a 0,08333 .

Tabela 34: Medidas de centralidade da Rede de Pesquisadores da Revista Organizações $\&$ Sociedade $(O \& S)$

\begin{tabular}{lc}
\hline \multicolumn{1}{c}{ Pesquisador } & Medida \\
\hline Centralidade de grau (degree) & \\
\hline ANA PAULA PAES DE PAULA & 0,03401 \\
ANTONIO CARVALHO NETO & 0,03401 \\
ARMINDO DOS SANTOS DE SOUSA TEODÓSIO & 0,03401 \\
DANIEL CALBINO PINHEIRO & 0,03401 \\
DIMITRI AUGUSTO DA CUNHA TOLEDO & 0,03401 \\
LEONARDO MASCARENHAS & 0,03401 \\
ROBERTO PATRUS PENA & 0,03401 \\
\hline Centralidade de intermediação (betweeneess) & \\
\hline JÚLIA FURLANETTO GRAEFF & 0,00019 \\
LUCIANA MOURÃO & 0,00019 \\
MARIA VILMA COELHO MOREIRA & 0,00019 \\
SERGIO BULGACOV & 0,00019
\end{tabular}


Centralidade de autovetor (eigenvector)

\begin{tabular}{ll}
\hline ANA PAULA PAES DE PAULA & 0,08333 \\
ANTONIO CARVALHO NETO & 0,08333 \\
ARMINDO DOS SANTOS DE SOUSA TEODÓSIO & 0,08333 \\
DANIEL CALBINO PINHEIRO & 0,08333 \\
DIMITRI AUGUSTO DA CUNHA TOLEDO & 0,08333 \\
LEONARDO MASCARENHAS & 0,08333 \\
ROBERTO PATRUS PENA & 0,08333 \\
\hline
\end{tabular}

Fonte: elaborado pela autora

Figura 22: Representação gráfica da centralidade de grau (degree), centralidade de intermediação (betweenness) e centralidade de autovetor (eigenvector) da Rede de Pesquisadores da Revista Organizações \& Sociedade (O\&S)
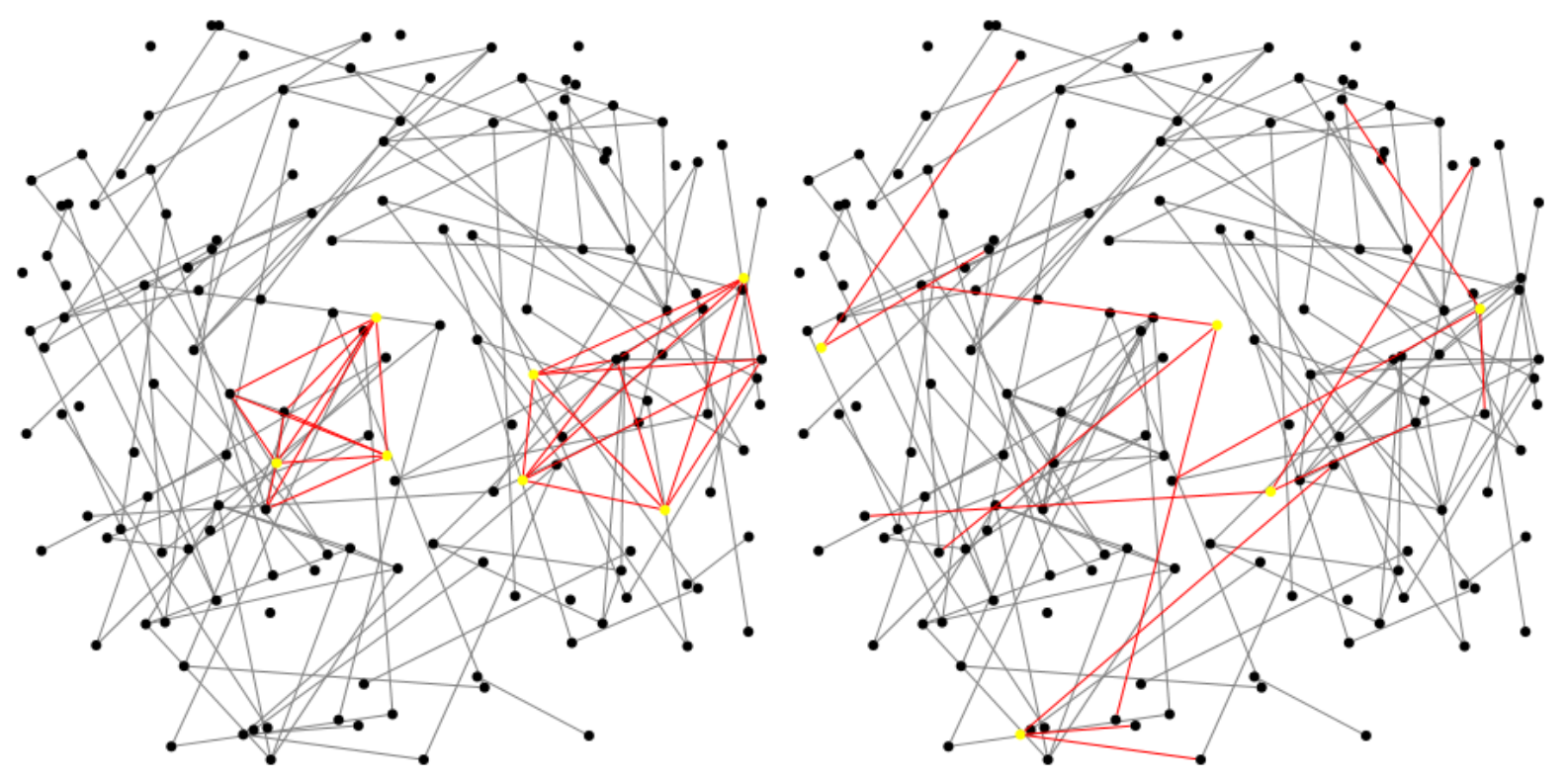


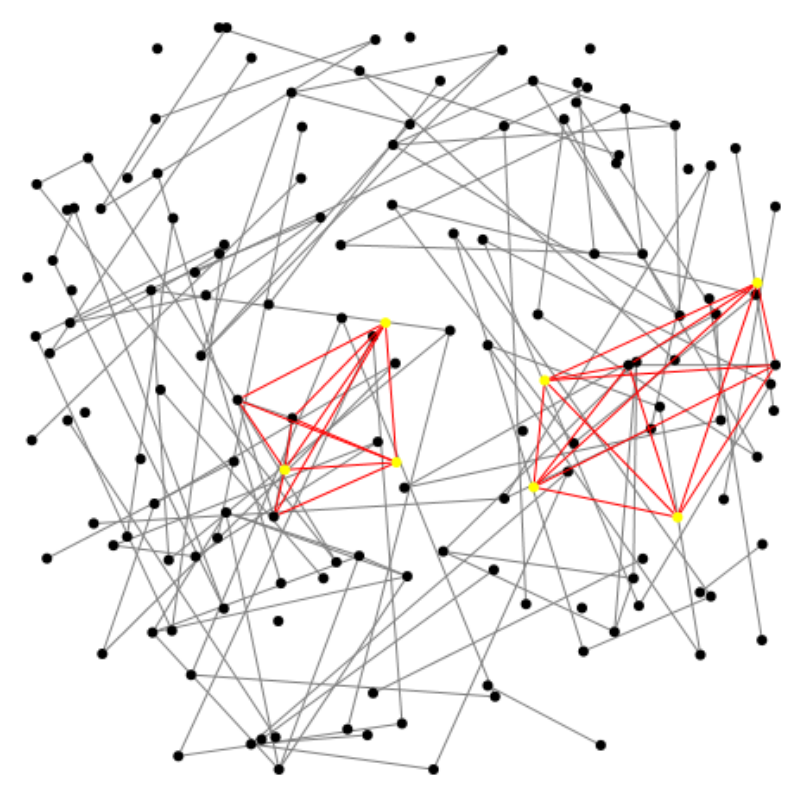

Fonte: elaborado pela autora

A análise dos atributos dos principais autores da Rede de Pesquisadores da Revista Organizações \& Sociedade (O\&S) nos mostra que $20 \%$ dos pesquisadores adquiriram seu título de doutorado na Universidade Federal de Minas Gerais. Outra parcela de $20 \%$ dos pesquisadores adquiriu sua última titulação acadêmica em universidades estrangeiras. Ao verificar a instituição em que os pesquisadores atuam profissionalmente, notamos uma preponderância para universidades do estado de Minas Gerais, pois $20 \%$ estão ligados à Pontifícia Universidade Católica de Minas Gerais, 13,33\% à Universidade Federal de Minas Gerais, 6,67\% à Universidade Federal de São João Del-Rei e 6,67\% à Universidade Federal de Alfenas, totalizando 46,67\% do total.

\section{Quadro 22: Atributos dos principais autores da Rede de Pesquisadores da da Revista Organizações \& Sociedade $(\mathrm{O \& S})^{9}$}

\begin{tabular}{|l|c|c|c|c|c|c|}
\hline \multirow{2}{*}{ Pesquisador(a) } & \multicolumn{3}{c|}{ Formação acadêmica } & \multicolumn{2}{c|}{ Atuação profissional } \\
\cline { 2 - 7 } & $\begin{array}{c}\text { Última } \\
\text { titulação }\end{array}$ & Instituição & Área & Subárea & $\begin{array}{c}\text { Vínculo } \\
\text { Institucional }\end{array}$ & Instituição \\
\hline $\begin{array}{l}\text { ANA PAULA PAES DE } \\
\text { PAULA }\end{array}$ & Doutorado & UNICAMP & Administração & $\begin{array}{c}\text { Administração } \\
\text { Pública }\end{array}$ & Professora & UFMG \\
\hline $\begin{array}{l}\text { ANDRÉA LEITE } \\
\text { RODRIGUES }\end{array}$ & Doutorado & FGV & Administração & $\begin{array}{c}\text { Administração } \\
\text { Geral }\end{array}$ & Professora & USP \\
\hline
\end{tabular}

\footnotetext{
${ }^{9}$ Não encontramos os dados do pesquisador Leonardo Mascarenhas
} 


\begin{tabular}{|c|c|c|c|c|c|c|}
\hline $\begin{array}{l}\text { ANTONIO CARVALHO } \\
\text { NETO }\end{array}$ & Doutorado & UFMG & $\begin{array}{l}\text { Sociologia / } \\
\text { Economia }\end{array}$ & $\begin{array}{c}\text { Outras Sociologias } \\
\text { Específicas / } \\
\text { Economia dos } \\
\text { Recursos } \\
\text { Humanos } \\
\end{array}$ & Professor & $\mathrm{PUC} / \mathrm{MG}$ \\
\hline $\begin{array}{l}\text { ARMINDO DOS SANTOS } \\
\text { DE SOUSA TEODÓSIO }\end{array}$ & Doutorado & FGV/SP & Administração & $\begin{array}{c}\text { Administração de } \\
\text { Empresas / } \\
\text { Administração } \\
\text { Pública }\end{array}$ & Professor & PUC/MG \\
\hline $\begin{array}{l}\text { DANIEL CALBINO } \\
\text { PINHEIRO }\end{array}$ & Doutorado & UFMG & Administração & & Professor & UFSJ \\
\hline $\begin{array}{l}\text { DEISE LUIZA DA SILVA } \\
\text { FERRAZ }\end{array}$ & Doutorado & UFRGS & Administração & $\begin{array}{c}\text { Administração de } \\
\text { Recursos } \\
\text { Humanos / } \\
\text { Administração de } \\
\text { Setores } \\
\text { Específicos } \\
\end{array}$ & Professora & UFMG \\
\hline $\begin{array}{l}\text { DIMITRI AUGUSTO DA } \\
\text { CUNHA TOLEDO }\end{array}$ & Mestrado & UFMG & Administração & & Professor & UNIFAL \\
\hline $\begin{array}{l}\text { GENAUTO CARVALHO } \\
\text { DE FRANÇA FILHO }\end{array}$ & Doutorado & $\begin{array}{c}\text { Université } \\
\text { Paris } \\
\text { Diderot }\end{array}$ & Sociologia & & Professor & UFBA \\
\hline $\begin{array}{l}\text { JÚLIA FURLANETTO } \\
\text { GRAEFF }\end{array}$ & Doutorado & UFPR & Administração & $\begin{array}{l}\text { Administração de } \\
\text { Empresas }\end{array}$ & $\begin{array}{l}\text { Pesquisadora } \\
\text { colaboradora }\end{array}$ & UFSC \\
\hline LUCIANA MOURÃO & Doutorado & UnB & Psicologia & $\begin{array}{l}\text { Psicologia do } \\
\text { Trabalho e } \\
\text { Organizacional }\end{array}$ & Professora & $\begin{array}{c}\text { Universidade } \\
\text { Salgado de } \\
\text { Oliveira }\end{array}$ \\
\hline LUCIANO MUNCK & Doutorado & USP & Administração & $\begin{array}{l}\text { Administração de } \\
\text { Empresas }\end{array}$ & Professor & UNICENTRO \\
\hline $\begin{array}{l}\text { MARIA VILMA COELHO } \\
\text { MOREIRA }\end{array}$ & Doutorado & $\begin{array}{l}\text { University } \\
\text { Of } \\
\text { Tennessee }\end{array}$ & Sociologia & $\begin{array}{l}\text { Sociologia do } \\
\text { Trabalho }\end{array}$ & Professora & UNILAB \\
\hline $\begin{array}{l}\text { ROBERTO PATRUS } \\
\text { PENA }\end{array}$ & Doutorado & $\begin{array}{c}\text { Universidad } \\
\text { Complutense } \\
\text { de Madrid }\end{array}$ & Filosofia & & Professor & PUC/MG \\
\hline SERGIO BULGACOV & Doutorado & FGV/SP & $\begin{array}{l}\text { Administração } \\
\text { de Empresas }\end{array}$ & & Professor & FGV/SP \\
\hline
\end{tabular}

Fonte: elaborado pela autora com base na Plataforma Lattes

A categorização dos pesquisadores da Rede de Pesquisadores da Revista Organizações \& Sociedade $(O \& S)$, segundo a regularidade de produção científica, tem a seguinte distribuição: $42,68 \%$ de one-timers, $22,93 \%$ de continuantes, $22,93 \%$ de retirantes, $11,46 \%$ de transientes e $0 \%$ de entrantes. 
Tabela 35: Categorização dos Pesquisadores da Rede de Pesquisadores da Revista Organizações \& Sociedade $(\mathrm{O \& S})$

\begin{tabular}{cc}
\hline Categoria & $\begin{array}{c}\text { \% do total de autorias do } \\
\text { periódico }\end{array}$ \\
\hline Continuantes & $22,93 \%$ \\
Transientes & $11,46 \%$ \\
One-timers & $42,68 \%$ \\
Entrantes & $0,00 \%$ \\
Retirantes & $22,93 \%$ \\
\hline \multicolumn{2}{c}{ Fonte: elaborado pela autora } \\
\hline
\end{tabular}

Assim como a Revista de Administração Pública (RAP), a revista Organizações \& Sociedade (O\&S) também possui uma alta classificação no Qualis Capes, o que a torna um periódico bastante competitivo. Sua linha editorial posiciona-se entre Estudos Organizações, Administração Pública e Gestão Social.

\subsection{Rede de Pesquisadores dos Cadernos de Gestão Pública e Cidadania}

Os Cadernos Gestão Pública e Cidadania são publicados pelo Centro de Administração Pública e Governo e pelo Departamento de Gestão Pública da Escola de Administração de Empresas de São Paulo da Fundação Getulio Vargas. O periódico já teve 67 números editados, sendo que o primeiro foi publicado no ano de 1997.

A Rede de Pesquisadores dos Cadernos de Gestão Pública e Cidadania é composta por 97 autores (vértices) e 77 ligações (arestas). Vale destacar que no período analisado por este trabalho não verificamos nenhuma ligação duplicada. Do total de pesquisadores da rede, $25,77 \%$ publicaram artigos sem coautoria, percentual bastante superior em relação aos demais eventos da área. A densidade da rede é de 0,0165378. 
Figura 23: Rede de Pesquisadores dos Cadernos de Gestão Pública e Cidadania

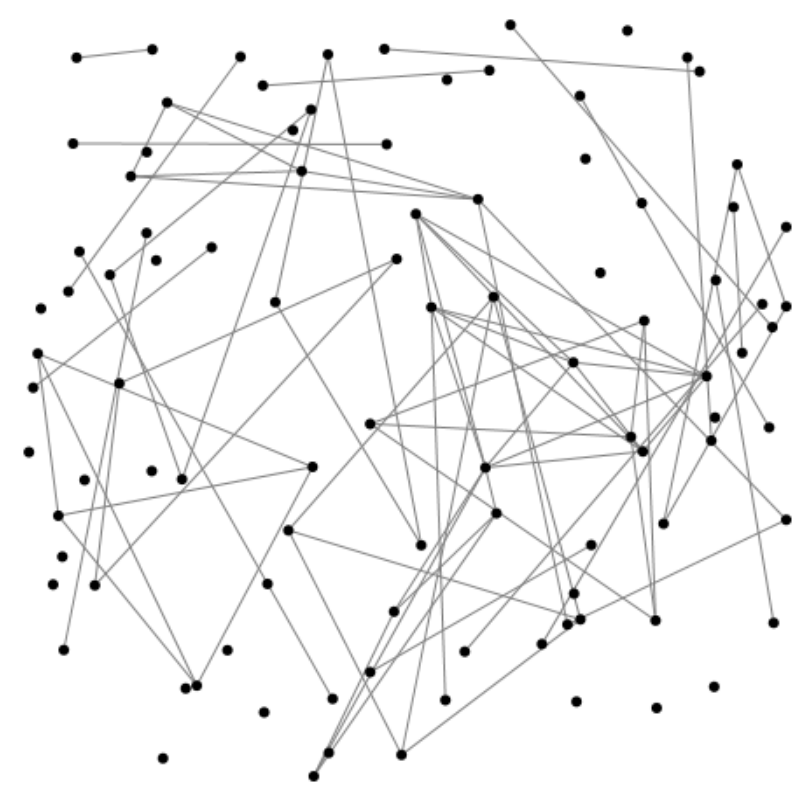

Fonte: elaborado pela autora

Os pesquisadores mais prolíficos da Rede de Pesquisadores dos Cadernos de Gestão Pública e Cidadania são Marco Antonio Carvalho Teixeira e Sandro Pereira Silva, com 3 publicações cada, e Carlos Eduardo Guerra Silva e Marcus Vinícius Peinado Gomes, com 2 publicações cada um.

Tabela 36: Autores mais prolíficos da Rede de Pesquisadores dos Cadernos de Gestão Pública e Cidadania

\begin{tabular}{lc}
\hline \multicolumn{1}{c}{ Pesquisador } & $\mathbf{N}^{\mathbf{0}}$ de publicações \\
\hline MARCO ANTONIO CARVALHO TEIXEIRA & 3 \\
SANDRO PEREIRA SILVA & 3 \\
CARLOS EDUARDO GUERRA SILVA & 2 \\
MARCUS VINÍCIUS PEINADO GOMES & 2 \\
\hline \multicolumn{1}{c}{ Fonte: elaborado pela autora }
\end{tabular}

Fonte: elaborado pela autora

Marco Antonio Carvalho Teixeira e Marcus Vinícius Peinado Gomes, além de estarem entre os pesquisadores mais prolíficos da rede, também apresentam as maiores medidas de centralidade de grau (degree), de intermediação (betweeneess) e de autovetor (eigenvector). Devemos ressaltar que não consideramos Malu Vilella, Luciana Stocco Betiol e Thiago Hector Kanashiro Uehara entre os pesquisadores com as maiores medidas de centralidade de 
grau (degree) e de autovetor (eigenvector $)^{10}$, pois são pesquisadores one-timers. Para a medida de centralidade de intermediação (betweeneess), apresentamos apenas três valores, pois os demais autores obtiveram resultados iguais a zero para esta medida.

Tabela 37: Medidas de centralidade da Rede de Pesquisadores dos Cadernos de Gestão Pública e Cidadania

\begin{tabular}{ll}
\hline \multicolumn{1}{c}{ Pesquisador } & Medida \\
\hline Centralidade de grau (degree) & \\
\hline MARCO ANTONIO CARVALHO TEIXEIRA & 0,08333 \\
MARCUS VINÍCIUS PEINADO GOMES & 0,06250 \\
MARIO PRESTES MONZONI NETO & 0,05208 \\
CARLOS EDUARDO GUERRA SILVA & 0,05208 \\
MARIA RITA LOUREIRO & 0,03125 \\
\hline Centralidade de intermediação (betweeneess) & \\
\hline MARCO ANTONIO CARVALHO TEIXEIRA & 0,00395 \\
MARCUS VINÍCIUS PEINADO GOMES & 0,00175 \\
CARLOS EDUARDO GUERRA SILVA & 0,00132 \\
\hline Centralidade de autovetor (eigenvector) & \\
\hline MARCO ANTONIO CARVALHO TEIXEIRA & 0,15680 \\
MARCUS VINÍCIUS PEINADO GOMES & 0,13745 \\
MARIO PRESTES MONZONI NETO & 0,13320 \\
MARIA RITA LOUREIRO & 0,04886 \\
FERNANDO LUIZ ABRUCIO & 0,04886 \\
\hline
\end{tabular}

Fonte: elaborado pela autora

${ }^{10}$ Malu Vilella, Luciana Stocco Betiol e Thiago Hector Kanashiro Uehara apresentaram uma medida de centralidade de grau (degree) de 0,05208 e de centralidade de autovetor (eigenvector) de 0,13320. 
Figura 24: Representação gráfica da centralidade de grau (degree), centralidade de intermediação (betweenness) e centralidade de autovetor (eigenvector) da Rede de Pesquisadores dos Cadernos de Gestão Pública e Cidadania

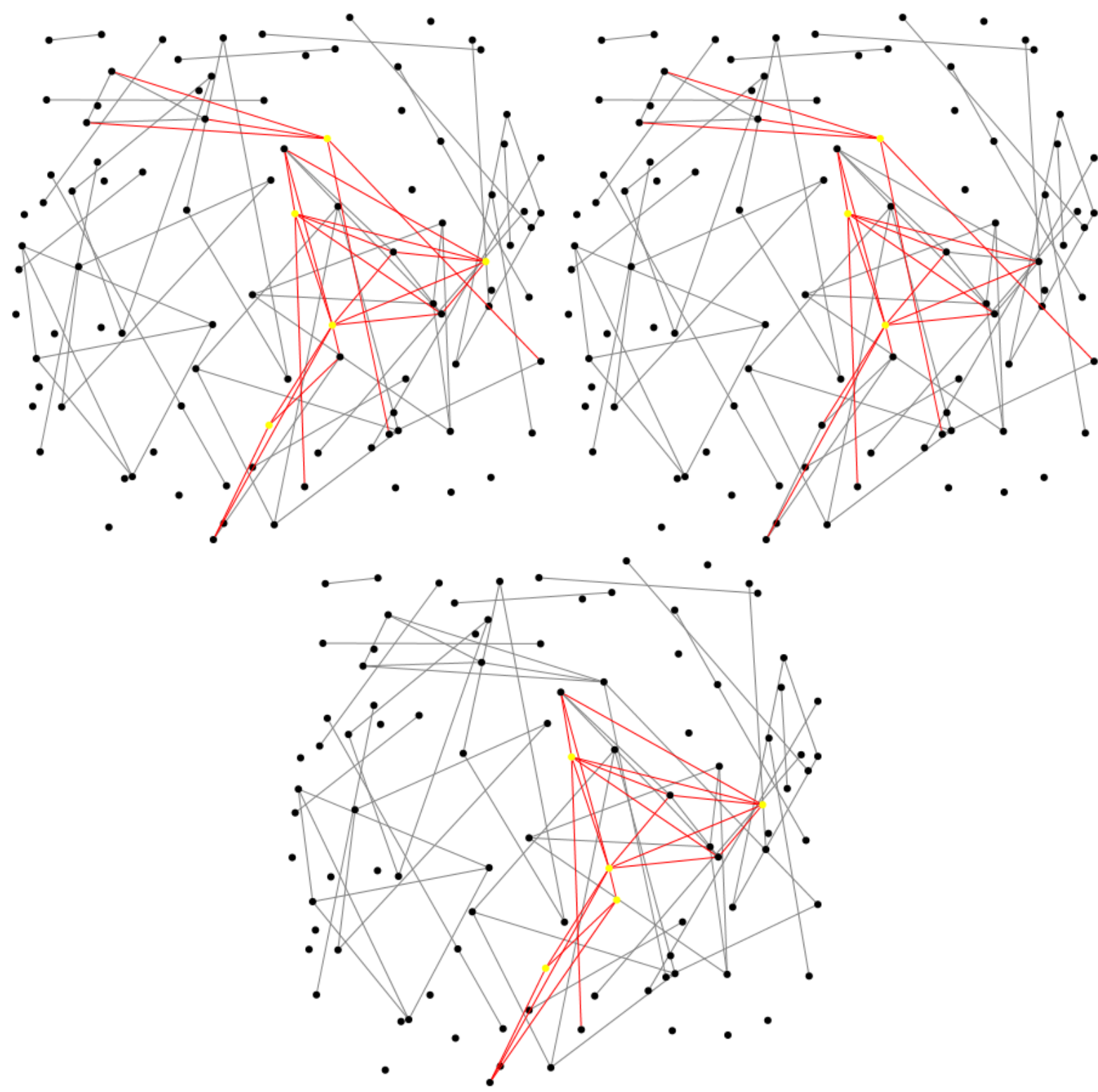

Fonte: elaborado pela autora

Analisando os atributos dos principais pesquisadores da Rede de Pesquisadores dos Cadernos de Gestão Pública e Cidadania notamos que 71,43\% atuam profissionalmente como professores na Fundação Getulio Vargas de São Paulo, a qual é responsável pela publicação do periódico. Em relação à formação acadêmica, 71,43\% dos pesquisadores adquiriram o título de mestrado ou doutorado em universidades paulistas, sendo que o restante $(28,57 \%)$ formou-se em universidades mineiras. 
Quadro 23: Atributos dos principais autores da Rede de Pesquisadores dos Cadernos de Gestão Pública e Cidadania

\begin{tabular}{|c|c|c|c|c|c|c|}
\hline \multirow[b]{2}{*}{ Pesquisador(a) } & \multicolumn{4}{|c|}{ Formação acadêmica } & \multicolumn{2}{|c|}{ Atuação profissional } \\
\hline & $\begin{array}{l}\text { Última } \\
\text { titulação }\end{array}$ & Instituição & Área & Subárea & $\begin{array}{c}\text { Vínculo } \\
\text { Institucional }\end{array}$ & Instituição \\
\hline $\begin{array}{l}\text { CARLOS EDUARDO } \\
\text { GUERRA SILVA }\end{array}$ & Doutorado & UFMG & Administração & & Professor & UFMG \\
\hline $\begin{array}{l}\text { FERNANDO LUIZ } \\
\text { ABRUCIO }\end{array}$ & Doutorado & USP & $\begin{array}{l}\text { Ciência } \\
\text { Política }\end{array}$ & Estado e Governo & Professor & FGV/SP \\
\hline $\begin{array}{l}\text { MARCO ANTONIO } \\
\text { CARVALHO TEIXEIRA }\end{array}$ & Doutorado & PUC/SP & Sociologia & & Professor & FGV/SP \\
\hline $\begin{array}{l}\text { MARCUS VINÍCIUS } \\
\text { PEINADO GOMES }\end{array}$ & Doutorado & FGV/SP & $\begin{array}{l}\text { Ciências } \\
\text { Sociais }\end{array}$ & & Professor & FGV/SP \\
\hline MARIA RITA LOUREIRO & Doutorado & USP & Sociologia & & Professor & FGV/SP \\
\hline $\begin{array}{l}\text { MARIO PRESTES } \\
\text { MONZONI NETO }\end{array}$ & Doutorado & FGV/SP & Administração & $\begin{array}{l}\text { Administração } \\
\text { Pública }\end{array}$ & Professor & FGV/SP \\
\hline $\begin{array}{l}\text { SANDRO PEREIRA } \\
\text { SILVA }\end{array}$ & Mestrado & UFV & $\begin{array}{l}\text { Engenharia } \\
\text { Mecânica }\end{array}$ & & $\begin{array}{c}\text { Técnico de } \\
\text { Planejamento } \\
\text { e Pesquisa }\end{array}$ & IPEA \\
\hline
\end{tabular}

Fonte: elaborado pela autora com base na Plataforma Lattes

Seguindo a tendência da Rede de Pesquisadores de Gestão Social (RPGS), 50,49\% dos autores da Rede de Pesquisadores dos Cadernos de Gestão Pública e Cidadania são onetimers. Os demais se distribuem entre $19,42 \%$ de transientes, $15,53 \%$ de continuantes, $12,62 \%$ de retirantes e apenas $1,94 \%$ de entrantes. Embora o percentual de one-timers seja alto, devemos destacar que a soma de pesquisadores continuantes e transientes é de $34,95 \%$.

Tabela 38: Categorização dos Pesquisadores da Rede de Pesquisadores dos Cadernos de Gestão Pública e Cidadania

\begin{tabular}{cc}
\hline Categoria & $\begin{array}{c}\text { \% do total de autorias do } \\
\text { periódico }\end{array}$ \\
\hline Continuantes & $15,53 \%$ \\
Transientes & $19,42 \%$ \\
One-timers & $50,49 \%$ \\
Entrantes & $1,94 \%$ \\
Retirantes & $12,62 \%$ \\
\hline
\end{tabular}

Fonte: elaborado pela autora 


\subsection{Rede de Pesquisadores da Administração Pública e Gestão Social (APGS)}

A Administração Pública e Gestão Social (APGS) é um período online vinculado à Universidade Federal de Viçosa (UFV). Suas publicações são trimestrais, sendo que o primeiro número foi lançado em 2009. Considerando o período considerado na pesquisa, analisamos 28 números publicados.

A Rede de Pesquisadores da Administração Pública e Gestão Social (APGS) possui 136 pesquisadores (vértices) e 147 ligações (arestas) entre eles, sendo que 138 ligações são únicas e 9 ligações são duplicadas, ou seja, os pesquisadores repetiram a parceria em mais de um artigo. Vale ressaltar que $8,82 \%$ dos pesquisadores publicaram artigos sozinhos, isto é, sem coautoria. Por fim, podemos apontar que a densidade da rede é de 0,01546841 .

\section{Figura 25: Rede de Pesquisadores da Administração Pública e Gestão Social (APGS)}

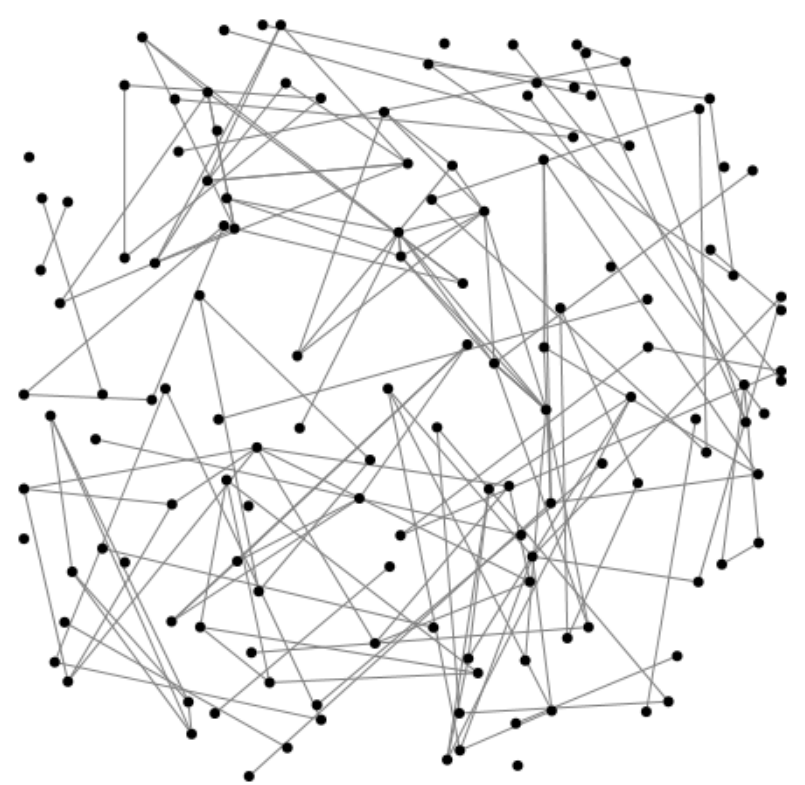

Fonte: elaborado pela autora

Os pesquisadores mais prolíficos da Rede de Pesquisadores da Administração Pública e Gestão Social (APGS) são Airton Cardoso Cançado e Ariádne Scalfoni Rigo, com 4 publicações cada um, e José Roberto Pereira, com 3 publicações. 
Tabela 39: Autores mais prolíficos da Rede de Pesquisadores da Administração Pública e Gestão Social (APGS)

\begin{tabular}{lc}
\hline \multicolumn{1}{c}{ Pesquisador } & $\mathbf{N}^{\mathbf{0}}$ de publicações \\
\hline AIRTON CARDOSO CANÇADO & 4 \\
ARIÁDNE SCALFONI RIGO & 4 \\
JOSÉ ROBERTO PEREIRA & 3 \\
\hline
\end{tabular}

Fonte: elaborado pela autora

Os três pesquisadores mais prolíficos, Airton Cardoso Cançado, Ariádne Scalfoni Rigo e José Roberto Pereira, também estão entre os autores com as maiores medidas de centralidade de grau (degree), intermediação (betweeneess) e autovetor (eigenvector). Outro autor que está entre os pesquisadores com as maiores medidas de centralidade é Fernando Guilherme Tenório.

Tabela 40: Medidas de centralidade da Rede de Pesquisadores da Administração Pública e Gestão Social (APGS)

\begin{tabular}{lc}
\hline \multicolumn{1}{c}{ Pesquisador } & Medida \\
\hline Centralidade de grau (degree) & \\
\hline FERNANDO GUILHERME TENÓRIO & 0,05185 \\
\hline ARIÁDNE SCALFONI RIGO & 0,04444 \\
AIRTON CARDOSO CANÇADO & 0,04444 \\
JOSÉ ROBERTO PEREIRA & 0,04444 \\
FLÁVIA DE PAULA DUQUE BRASIL & 0,04444 \\
\hline Centralidade de intermediação (betweeneess) & \\
\hline FERNANDO GUILHERME TENÓRIO & 0,00332 \\
ARIÁDNE SCALFONI RIGO & 0,00221 \\
AIRTON CARDOSO CANÇADO & 0,00221 \\
\hline JOSÉ ROBERTO PEREIRA & 0,00188 \\
JOSÉ RAIMUNDO CORDEIRO NETO & 0,00133 \\
\hline Centralidade de autovetor (eigenvector) & \\
\hline FERNANDO GUILHERME TENÓRIO & 0,13975 \\
\hline ARIÁDNE SCALFONI RIGO & 0,12728 \\
\hline AIRTON CARDOSO CANÇADO & 0,12728 \\
\hline JOSÉ ROBERTO PEREIRA & 0,12658 \\
\hline VÂNIA APARECIDA REZENDE DE OLIVEIRA & 0,12186 \\
\hline \multicolumn{1}{c}{ Fonte: elaborado pela autora } \\
\hline
\end{tabular}


Figura 26: Representação gráfica da centralidade de grau (degree), centralidade de intermediação (betweenness) e centralidade de autovetor (eigenvector) da Rede de Pesquisadores da Administração Pública e Gestão Social (APGS)
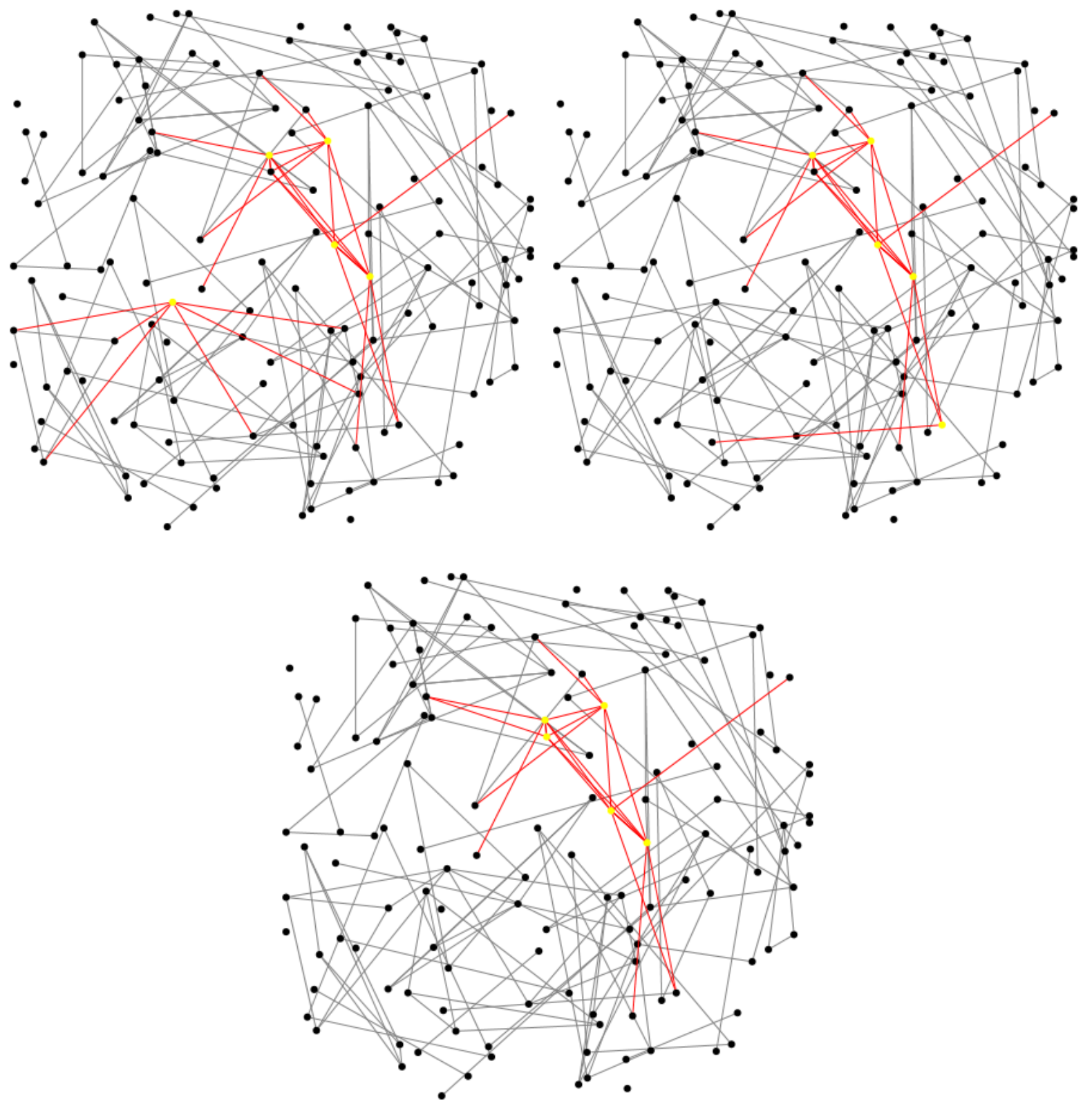

Fonte: elaborado pela autora

Dois dos pesquisadores em destaque na rede cursaram doutorado na Universidade Federal de Lavras (Airton Cardoso Cançado e Vânia Aparecida Rezende de Oliveira) e $42,86 \%$ dos pesquisadores adquiriram sua última titulação em alguma universidade mineira (UFLA e UFMG). Ao focarmos nas instituições em que os pesquisadores mantêm vínculos profissionais, podemos perceber que $42,86 \%$ estão em universidades e fundações do estado de 
Minas Gerais e os demais estão distribuídos pelos estados da Bahia, Pernambuco, Rio de Janeiro e Tocantins.

Quadro 24: Atributos dos principais autores da Rede de Pesquisadores da
Administração Pública e Gestão Social (APGS)

\begin{tabular}{|l|c|c|c|c|c|c|}
\hline \multicolumn{1}{|c|}{ Pesquisador(a) } & \multicolumn{2}{c|}{ Formação acadêmica } & \multicolumn{2}{c|}{ Atuação profissional } \\
\cline { 2 - 7 } & $\begin{array}{c}\text { Última } \\
\text { titulação }\end{array}$ & Instituição & Área & Subárea & $\begin{array}{c}\text { Vínculo } \\
\text { Institucional }\end{array}$ & Instituição \\
\hline $\begin{array}{l}\text { AIRTON CARDOSO } \\
\text { CANÇADO }\end{array}$ & Doutorado & UFLA & Administração & Professor & UFT \\
\hline $\begin{array}{l}\text { ARIÁDNE SCALFONI } \\
\text { RIGO }\end{array}$ & Doutorado & UFBA & Administração & & Professora & UFBA \\
\hline $\begin{array}{l}\text { FERNANDO } \\
\text { GUILHERME TENÓRIO }\end{array}$ & Doutorado & UFRJ & $\begin{array}{c}\text { Engenharia de } \\
\text { Produção }\end{array}$ & Professor & FGV \\
\hline $\begin{array}{l}\text { FLÁVIA DE PAULA } \\
\text { DUQUE BRASIL }\end{array}$ & Doutorado & UFMG & $\begin{array}{c}\text { Sociologia / } \\
\text { Ciência }\end{array}$ & $\begin{array}{c}\text { Outras Sociologias } \\
\text { Específicas / } \\
\text { Políticas Públicas }\end{array}$ & $\begin{array}{c}\text { Professora / } \\
\text { Pesquisadora }\end{array}$ & $\begin{array}{c}\text { Fundação } \\
\text { João } \\
\text { Pinheiro }\end{array}$ \\
\hline $\begin{array}{l}\text { JOSÉ RAIMUNDO } \\
\text { CORDEIRO NETO }\end{array}$ & Mestrado & UFPE & Administração & & Professor & UNIVASF \\
\hline $\begin{array}{l}\text { JOSÉ ROBERTO } \\
\text { PEREIRA }\end{array}$ & Doutorado & UnB & Sociologia & $\begin{array}{c}\text { Sociologia do } \\
\text { Desenvolvimento }\end{array}$ & Professor & UFLA \\
\hline $\begin{array}{l}\text { VÂNIA APARECIDA } \\
\text { REZENDE DLIVIRA }\end{array}$ & Doutorado & UFLA & Administração & Professora & UFSJ \\
\hline
\end{tabular}

Fonte: elaborado pela autora com base na Plataforma Lattes

Curiosamente, o número de pesquisadores one-timers não representa a maior parcela dos pesquisadores da Rede de Pesquisadores da Administração Pública e Gestão Social (APGS). Esta categoria representa 25,64\% do total, sendo que a maior fatia é composta por pesquisadores continuantes, que representam 33,33\% da totalidade. Na sequência, temos $21,79 \%$ de pesquisadores transientes, $17,31 \%$ de pesquisadores retirantes e apenas $1,92 \%$ de pesquisadores entrantes. 
Tabela 41: Categorização dos Pesquisadores da Rede de Pesquisadores da Administração Pública e Gestão Social (APGS)

\begin{tabular}{cc}
\hline Categoria & $\begin{array}{c}\text { \% do total de autorias do } \\
\text { periódico }\end{array}$ \\
\hline Continuantes & $33,33 \%$ \\
Transientes & $21,79 \%$ \\
One-timers & $25,64 \%$ \\
Entrantes & $1,92 \%$ \\
Retirantes & $17,31 \%$ \\
\hline \multicolumn{2}{c}{ Fonte: elaborado pela autora } \\
\end{tabular}

Vale ressaltar que a revista Administração Pública e Gestão Social (APGS) foi o primeiro periódico a levar o termo "Gestão Social” em seu nome. Além disso, é editorado por pesquisadores pertencentes à Rede de Pesquisadores de Gestão Social (RGS), o que acaba por atrair os pesquisadores do campo. Outro atrativo é que, dos periódicos "puro sangue" de Gestão Social, é o que possui maior classificação no Qualis Capes.

\subsection{Rede de Pesquisadores da NAU Social}

A NAU Social é uma revista online, fundada em 2010, vinculada ao Centro Interdisciplinar de Desenvolvimento e Gestão Social (CIAGS) da Escola de Administração da Universidade Federal da Bahia (UFBA). Desde sua fundação, o periódico teve 11 números publicados.

A Rede de Pesquisadores da NAU Social possui 237 pesquisadores (vértices) e 231 ligações (arestas), sendo 222 delas únicas e 9 duplicadas. Do total de pesquisadores, 29,11\% publicaram apenas artigos sem coautoria. A densidade da rede é de 0,0080812 . 
Figura 27: Rede de Pesquisadores da NAU Social

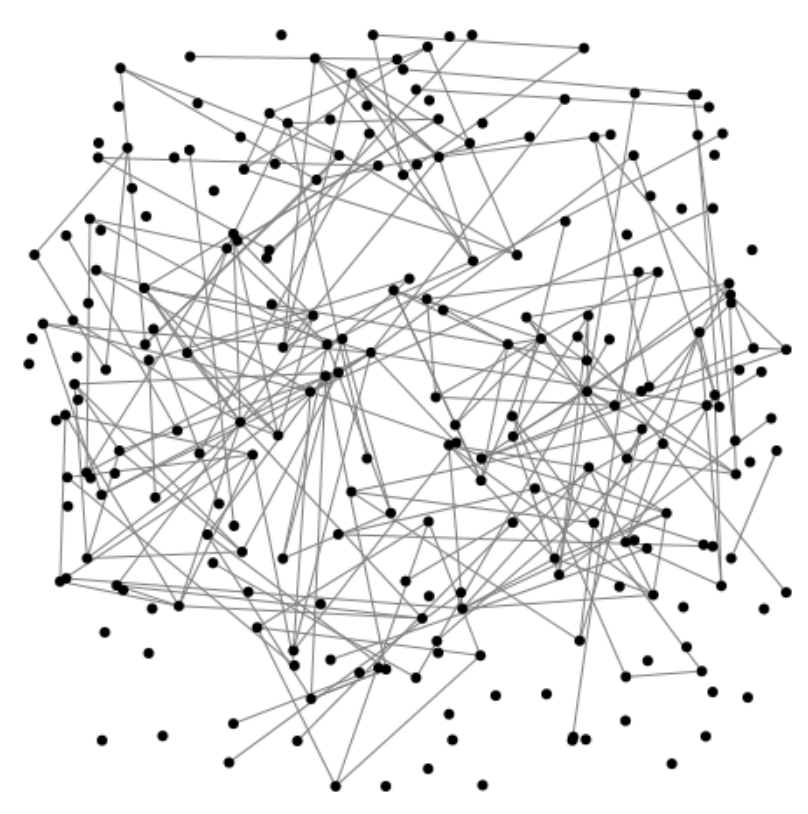

Fonte: elaborado pela autora

Os autores mais prolíficos da Rede de Pesquisadores da NAU Social são: Airton Cardoso Cançado e José Roberto Pereira, com 5 publicações cada, e Eduardo Vivian da Cunha e Rosana de Freitas Boullosa, com 4 publicações cada.

Tabela 42: Autores mais prolíficos da Rede de Pesquisadores da NAU Social

\begin{tabular}{lc}
\hline \multicolumn{1}{c}{ Pesquisador } & $\mathbf{N}^{\mathbf{0}}$ de publicações \\
\hline AIRTON CARDOSO CANÇADO & 5 \\
JOSÉ ROBERTO PEREIRA & 5 \\
EDUARDO VIVIAN DA CUNHA & 4 \\
ROSANA DE FREITAS BOULLOSA & 4 \\
\hline
\end{tabular}

Fonte: elaborado pela autora

Airton Cardoso Cançado, José Roberto Pereira e Eduardo Vivian da Cunha, além de estarem entre os pesquisadores mais prolíficos da Rede de Pesquisadores da NAU Social, também estão entre as maiores medidas de centralidade de grau (degree), de intermediação (betweeneess) e de autovetor (eigenvector). Outra pesquisadora que merece destaque é Maria Laís dos Santos Leite Leal, que também está entre os pesquisadores com as maiores medidas de centralidade. Vale destacar que excluímos da análise de centralidade de autovetor 
(eigenvector) os pesquisadores Maria Bianca Pinheiro de Moura e Tiago Pereira da Silva, pois são classificados como one-timers.

Tabela 43: Medidas de centralidade da Rede de Pesquisadores da NAU Social

\begin{tabular}{|c|c|}
\hline Pesquisador & Medida \\
\hline \multicolumn{2}{|l|}{ Centralidade de grau (degree) } \\
\hline JOSÉ ROBERTO PEREIRA & 0,03814 \\
\hline MARIA LAÍS DOS SANTOS LEITE LEAL & 0,03814 \\
\hline LUCIANO ANTONIO PRATES JUNQUEIRA & 0,03390 \\
\hline AIRTON CARDOSO CANÇADO & 0,02966 \\
\hline CELME TORRES FERREIRA DA COSTA & 0,02966 \\
\hline \multicolumn{2}{|l|}{ Centralidade de intermediação (betweeneess) } \\
\hline MARIA LAÍS DOS SANTOS LEITE LEAL & 0,00191 \\
\hline EDUARDO VIVIAN DA CUNHA & 0,00162 \\
\hline JOSÉ ROBERTO PEREIRA & 0,00126 \\
\hline LUCIANO ANTONIO PRATES JUNQUEIRA & 0,00105 \\
\hline CELME TORRES FERREIRA DA COSTA & 0,00097 \\
\hline \multicolumn{2}{|l|}{ Centralidade de autovetor (eigenvector) } \\
\hline MARIA LAÍS DOS SANTOS LEITE LEAL & 0,14798 \\
\hline ÍTALO ANDERSON TAUMATURGO DOS SANTOS & 0,11881 \\
\hline JOSEANE QUEIROZ VIEIRA & 0,11881 \\
\hline WALÉRIA MARIA MENEZES MORAIS DE ALENCAR & 0,11881 \\
\hline EDUARDO VIVIAN DA CUNHA & 0,05728 \\
\hline
\end{tabular}


Figura 28: Representação gráfica da centralidade de grau (degree), centralidade de intermediação (betweenness) e centralidade de autovetor (eigenvector) da Rede de

\section{Pesquisadores da NAU Social}
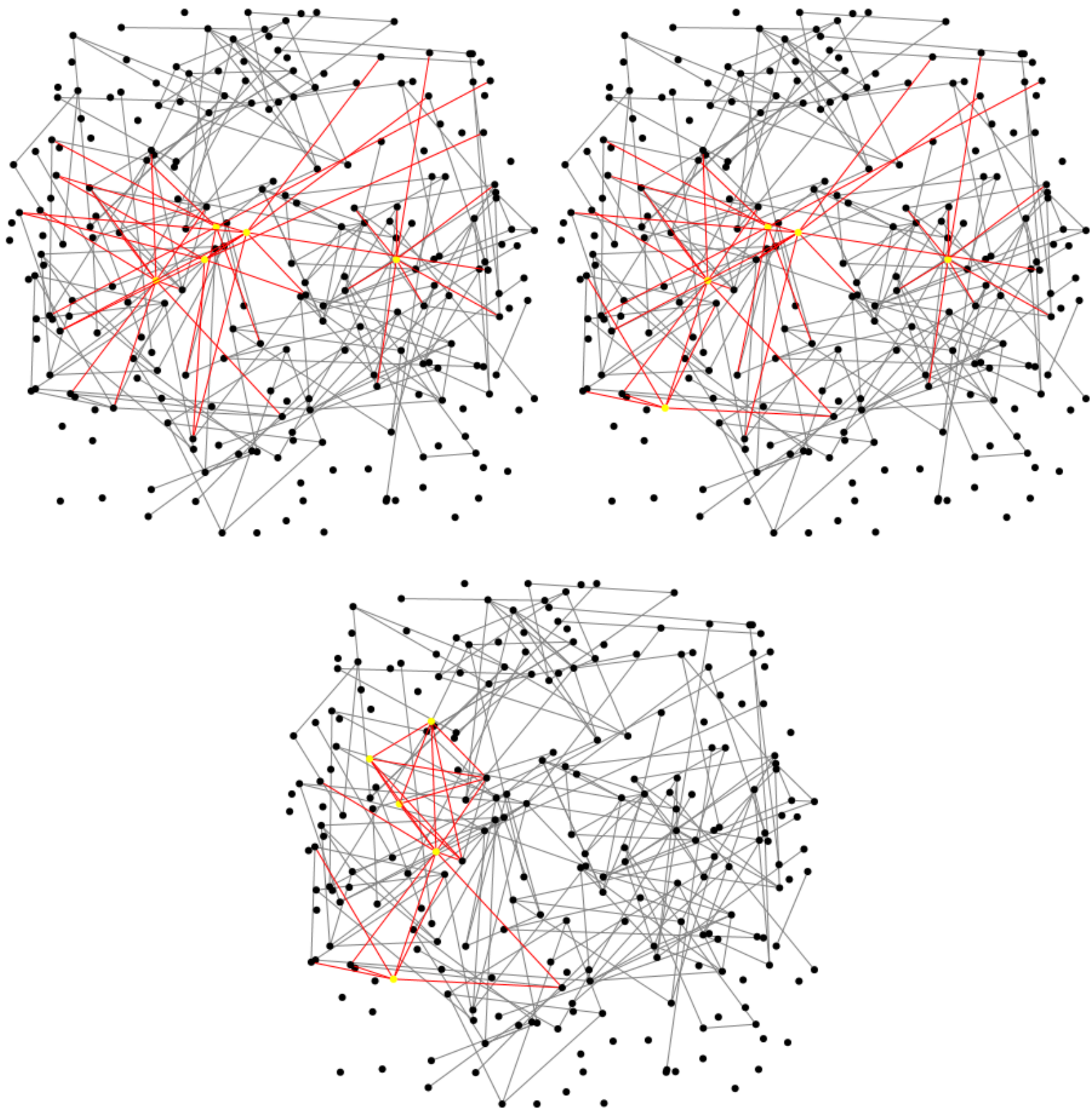

Fonte: elaborado pela autora

Notamos que os principais pesquisadores adquiriram sua ultima titulação acadêmica principalmente fora do eixo Rio-São Paulo, com destaque para a Universidade Federal do Ceará (UFC), responsável pela formação de $20 \%$ dos pesquisadores. Novamente, o estado do Ceará se destaca quando analisamos a vinculação institucional relacionada à atuação profissional, pois $40 \%$ dos pesquisadores estão ligados à Universidade Federal do Cariri 
(UFCA). Os demais pesquisadores estão vinculados à Universidade Federal do Tocantins, Faculdade Leão Sampaio (Ceará), Universidade Federal da Bahia, Universidade Federal de Lavras (Minas Gerais), Pontifícia Universidade Católica de São Paulo e Enactus Brasil (São Paulo).

\section{Quadro 25: Atributos dos principais autores da Rede de Pesquisadores da NAU Social}

\begin{tabular}{|c|c|c|c|c|c|c|}
\hline \multirow[b]{2}{*}{ Pesquisador(a) } & \multicolumn{4}{|c|}{ Formação acadêmica } & \multicolumn{2}{|c|}{ Atuação profissional } \\
\hline & $\begin{array}{l}\text { Última } \\
\text { titulação }\end{array}$ & Instituição & Área & Subárea & $\begin{array}{c}\text { Vínculo } \\
\text { Institucional } \\
\end{array}$ & Instituição \\
\hline $\begin{array}{l}\text { AIRTON } \\
\text { CARDOSO } \\
\text { CANÇADO }\end{array}$ & Doutorado & UFLA & Administração & & Professor & UFT \\
\hline $\begin{array}{l}\text { CELME } \\
\text { TORRES } \\
\text { FERREIRA DA } \\
\text { COSTA }\end{array}$ & Doutorado & UFC & Engenharia Civil & Modelagem & Professora & UFCA \\
\hline $\begin{array}{l}\text { EDUARDO } \\
\text { VIVIAN DA } \\
\text { CUNHA }\end{array}$ & Doutorado & UFBA & Administração & $\begin{array}{l}\text { Administração de } \\
\text { Setores Específicos }\end{array}$ & Professor & UFCA \\
\hline $\begin{array}{l}\text { ÍTALO } \\
\text { ANDERSON } \\
\text { TAUMATURGO } \\
\text { DOS SANTOS }\end{array}$ & Graduação & UFC & Administração & & $\begin{array}{l}\text { Gerente de } \\
\text { programa }\end{array}$ & $\begin{array}{c}\text { Enactus } \\
\text { Brasil }\end{array}$ \\
\hline $\begin{array}{l}\text { JOSÉ } \\
\text { ROBERTO } \\
\text { PEREIRA }\end{array}$ & Doutorado & UnB & Sociologia & $\begin{array}{l}\text { Sociologia Rural / } \\
\text { Sociologia do } \\
\text { Desenvolvimento }\end{array}$ & Professor & UFLA \\
\hline $\begin{array}{l}\text { JOSEANE } \\
\text { QUEIROZ } \\
\text { VIEIRA }\end{array}$ & Mestrado & UNISC & Direito & & Professora & $\begin{array}{l}\text { Faculdade } \\
\text { Leão } \\
\text { Sampaio }\end{array}$ \\
\hline $\begin{array}{l}\text { LUCIANO } \\
\text { ANTONIO } \\
\text { PRATES } \\
\text { JUNQUEIRA } \\
\end{array}$ & Doutorado & USP & Administração & $\begin{array}{l}\text { Administração } \\
\text { Pública }\end{array}$ & Professor & PUC/SP \\
\hline $\begin{array}{l}\text { MARIA LAÍS } \\
\text { DOS SANTOS } \\
\text { LEITE LEAL }\end{array}$ & Graduação & $\begin{array}{l}\text { Faculdade } \\
\text { Leão } \\
\text { Sampaio }\end{array}$ & Psicologia & & $\begin{array}{c}\text { Servidora } \\
\text { técnico- } \\
\text { administrativa } \\
\text { / pesquisadora } \\
\text { discente }\end{array}$ & UFCA \\
\hline $\begin{array}{l}\text { ROSANA DE } \\
\text { FREITAS } \\
\text { BOULLOSA }\end{array}$ & Doutorado & $\begin{array}{l}\text { Università } \\
\text { IUAV di } \\
\text { Venezia }\end{array}$ & $\begin{array}{l}\text { Planejamento } \\
\text { Urbano e Regional }\end{array}$ & $\begin{array}{c}\text { Fundamentos do } \\
\text { Planejamento } \\
\text { Urbano e Regional } \\
\text { / Serviços Urbanos } \\
\text { e Regionais }\end{array}$ & Professora & UFBA \\
\hline $\begin{array}{l}\text { WALÉRIA } \\
\text { MARIA } \\
\text { MENEZES } \\
\text { MORAIS DE } \\
\text { ALENCAR }\end{array}$ & Mestrado & $\begin{array}{l}\text { Fundação } \\
\text { Joaquim } \\
\text { Nabuco }\end{array}$ & $\begin{array}{c}\text { Gestão de Políticas } \\
\text { Públicas }\end{array}$ & & Professora & UFCA \\
\hline
\end{tabular}

Fonte: elaborado pela autora com base na Plataforma Lattes 
Utilizando o critério de regularidade de produção científica, podemos verificar que $41,96 \%$ dos pesquisadores são classificados como one-timers, $21,68 \%$ como transientes, $16,78 \%$ como continuantes, $12,59 \%$ como retirantes e $6,99 \%$ como entrantes.

Tabela 44: Categorização dos Pesquisadores da Rede de Pesquisadores da NAU Social

\begin{tabular}{cc}
\hline Categoria & $\begin{array}{c}\text { \% do total de autorias do } \\
\text { periódico }\end{array}$ \\
\hline Continuantes & $16,78 \%$ \\
Transientes & $21,68 \%$ \\
One-timers & $41,96 \%$ \\
Entrantes & $6,99 \%$ \\
Retirantes & $12,59 \%$ \\
\hline \multicolumn{2}{c}{ Fonte: elaborado pela autora }
\end{tabular}

É possível verificar a presença de diversos pesquisadores da Rede de Pesquisadores de Gestão Social (RGS) entre os que tiveram destaque na análise. Inclusive a equipe editorial da revista é composta por vários pesquisadores da rede RGS também, como é o caso da editorachefe, professora Rosana de Freitas Boullosa. Outro ponto de destaque é que os pesquisadores estão ligados, majoritariamente, a universidades da região nordeste.

\subsection{Rede de Pesquisadores dos Cadernos de Gestão Social}

O periódico Cadernos de Gestão Social (CGS) foi criado em 2007 pelo Centro Interdisciplinar de Desenvolvimento e Gestão Social (CIAGS), da Escola de Administração da Universidade Federal da Bahia (EA/UFBA). Em 2011, o periódico passou por uma reestruturação, após a qual passou a ser publicado semestralmente em parceria com a Rede de Pesquisadores de Gestão Social (RGS). Desde sua criação, foram publicados 8 números.

A Rede de Pesquisadores dos Cadernos de Gestão Social (CGS) conta com 139 pesquisadores (vértices) e 128 parcerias (arestas) entre os pesquisadores. Do total de pesquisadores da rede, 17,99\% publicaram apenas artigos sem coautoria. A densidade da Rede de Pesquisadores dos Cadernos de Gestão Social (CGS) é de 0,0133458. 
Figura 29: Rede de Pesquisadores dos Cadernos de Gestão Social (CGS)

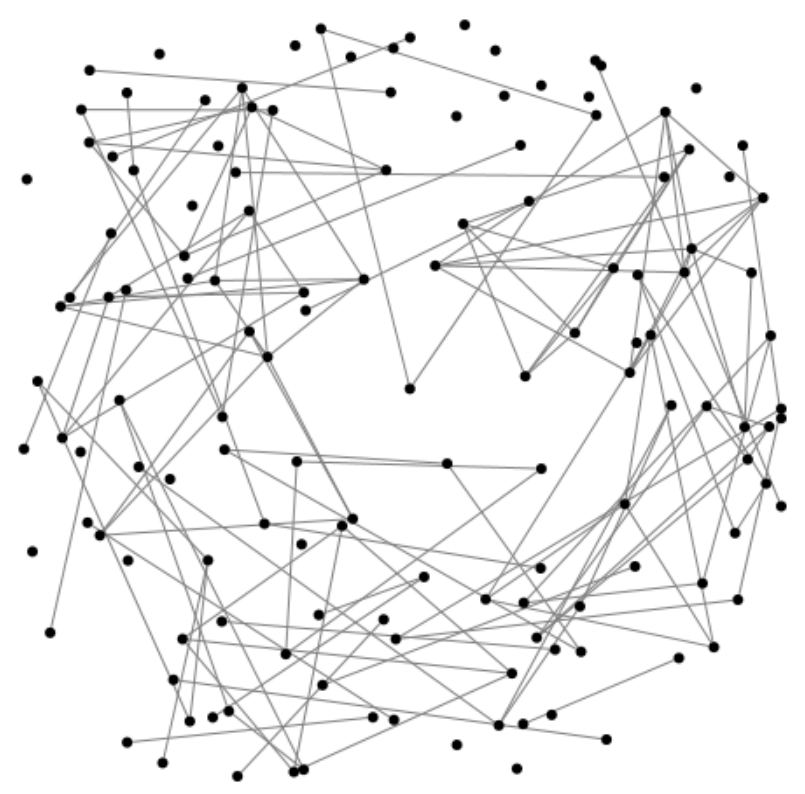

Fonte: elaborado pela autora

Os autores mais prolíficos da Rede de Pesquisadores dos Cadernos de Gestão Social (CGS) possuem duas publicações cada. Eles podem ser vistos na tabela 45, abaixo.

Tabela 45: Autores mais prolíficos da Rede de Pesquisadores dos Cadernos de Gestão Social (CGS)

\begin{tabular}{lc}
\hline \multicolumn{1}{c}{ Pesquisador } & $\mathbf{N}^{\mathbf{0}}$ de publicações \\
\hline AIRTON CARDOSO CANÇADO & 2 \\
ARIÁDNE SCALFONI RIGO & 2 \\
IVAN BECK CKAGNAZAROFF & 2 \\
JOSÉ ROBERTO PEREIRA & 2 \\
JUAN LEANDRO MUNT & 2 \\
MÁRIO VASCONCELLOS SOBRINHO & 2 \\
MIGUEL PACÍFICO FILHO & 2 \\
REBECA DA ROCHA GRANGEIRO & 2 \\
REZILDA RODRIGUES OLIVEIRA & 2 \\
SYLMARA LOPES FRANCELINO GONÇALVES-DIAS & 2 \\
\hline \multicolumn{2}{r}{ Fonte: elaborado pela autora } \\
\hline
\end{tabular}

Fonte: elaborado pela autora

Ivan Beck Ckagnazaroff está entre os pesquisadores com as maiores medidas de centralidade de grau (degree), de intermediação (betweeneess) e de intermediação 
(betweeneess). Sylmara Lopes Francelino Gonçalves-Dias, Artur Campos Cheib, Carolina Riente de Andrade e Mirian Lúcia Jácome Machado também são pesquisadores que aparecem em mais de um ranking com as maiores medidas de centralidade. Devemos destacar que, embora Bruno Valadares de Abreu e Gabriela Teixeira Vieira figurem entre os pesquisadores com as maiores medidas de centralidade de grau (degree) e de intermediação (betweeneess), eles são classificados como pesquisadores one-timers, motivo pelo qual não os consideramos na análise.

Tabela 46: Medidas de centralidade da Rede de Pesquisadores dos Cadernos de Gestão Social (CGS)

\begin{tabular}{|c|c|}
\hline Pesquisador & Medida \\
\hline \multicolumn{2}{|l|}{ Centralidade de grau (degree) } \\
\hline IVAN BECK CKAGNAZAROFF & 0,05072 \\
\hline SYLMARA LOPES FRANCELINO GONÇALVES-DIAS & 0,05072 \\
\hline ARTUR CAMPOS CHEIB & 0,03623 \\
\hline CAROLINA RIENTE DE ANDRADE & 0,03623 \\
\hline MIRIAN LÚCIA JÁCOME MACHADO & 0,03623 \\
\hline \multicolumn{2}{|l|}{ Centralidade de intermediação (betweeneess) } \\
\hline SYLMARA LOPES FRANCELINO GONÇALVES-DIAS & 0,00127 \\
\hline IVAN BECK CKAGNAZAROFF & 0,00106 \\
\hline AIRTON CARDOSO CANÇADO & 0,00021 \\
\hline JOSÉ ROBERTO PEREIRA & 0,00021 \\
\hline MÁRIO VASCONCELLOS SOBRINHO & 0,00021 \\
\hline REBECA DA ROCHA GRANGEIRO & 0,00021 \\
\hline \multicolumn{2}{|l|}{ Centralidade de autovetor (eigenvector) } \\
\hline IVAN BECK CKAGNAZAROFF & 0,16427 \\
\hline ARTUR CAMPOS CHEIB & 0,15107 \\
\hline CAROLINA RIENTE DE ANDRADE & 0,15107 \\
\hline MIRIAN LÚCIA JÁCOME MACHADO & 0,15107 \\
\hline HUDSON FERNANDES AMARAL & 0,04019 \\
\hline
\end{tabular}


Figura 30: Representação gráfica da centralidade de grau (degree), centralidade de intermediação (betweenness) e centralidade de autovetor (eigenvector) da Rede de Pesquisadores dos Cadernos de Gestão Social (CGS)
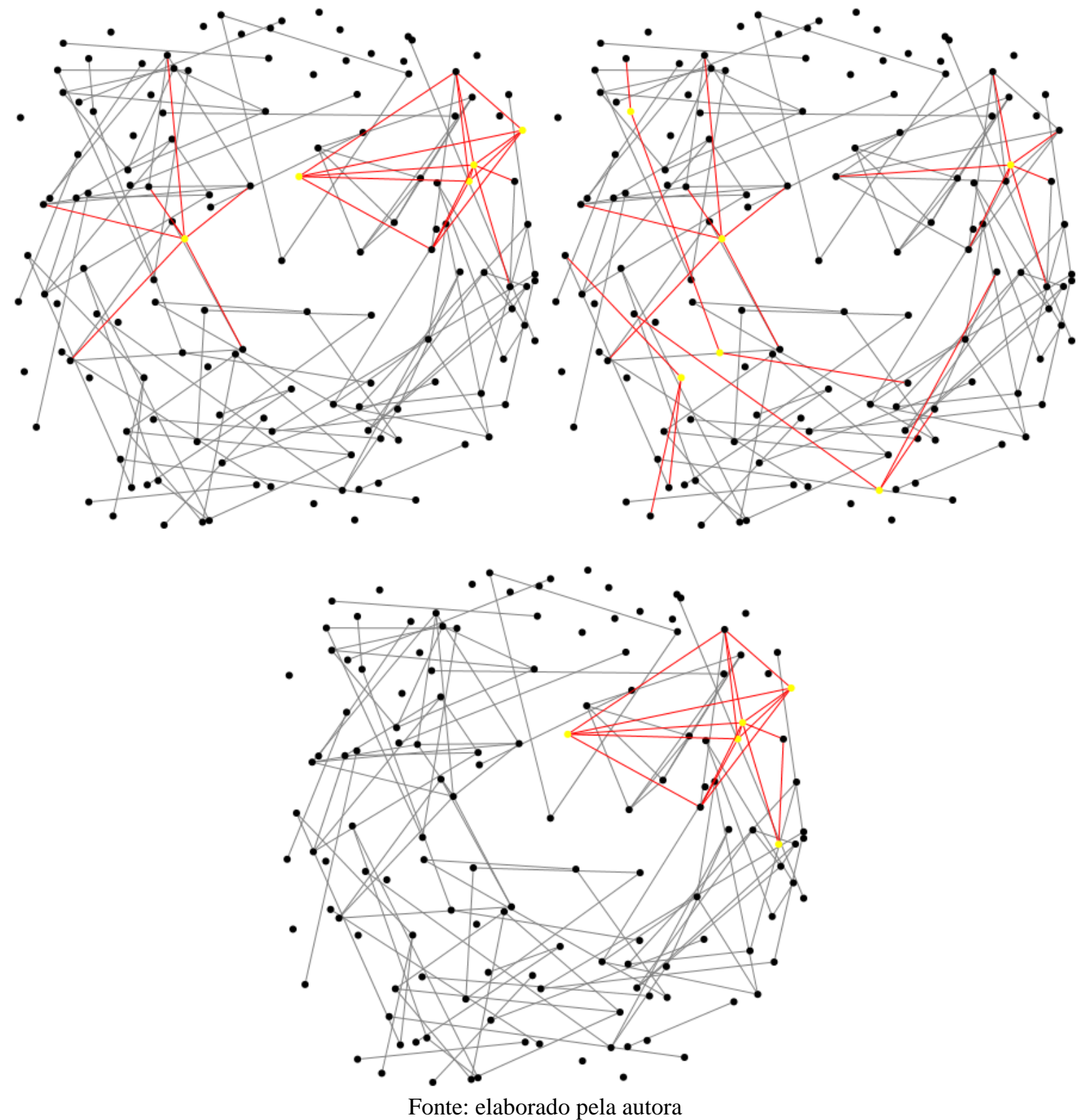

A Universidade Federal de Minas Gerais foi a instituição em que 21,43\% dos pesquisadores em destaque da rede se formaram academicamente. Na sequência, destacamos a Universidade Federal da Bahia, que foi responsável pela formação acadêmica de 14,29\% dos principais pesquisadores. Ao analisar as instituições em que os pesquisadores estão vinculados profissionalmente, notamos que, dos pesquisadores do quadro 25 , dois deles são vinculados atualmente à Universidade Federal do Tocantins e outros dois à Universidade Federal de Minas Gerais. 
Quadro 26: Atributos dos principais autores da Rede de Pesquisadores dos Cadernos de Gestão Social (CGS)

\begin{tabular}{|c|c|c|c|c|c|c|}
\hline \multirow[b]{2}{*}{ Pesquisador(a) } & \multicolumn{4}{|c|}{ Formação acadêmica } & \multicolumn{2}{|c|}{ Atuação profissional } \\
\hline & $\begin{array}{c}\text { Última } \\
\text { titulação }\end{array}$ & Instituição & Área & Subárea & \begin{tabular}{|c|} 
Vínculo \\
Institucional
\end{tabular} & Instituição \\
\hline $\begin{array}{l}\text { AIRTON CARDOSO } \\
\text { CANÇADO }\end{array}$ & Doutorado & UFLA & Administração & & Professor & UFT \\
\hline $\begin{array}{l}\text { ARIÁDNE SCALFONI } \\
\text { RIGO }\end{array}$ & Doutorado & UFBA & Administração & & Professora & UFBA \\
\hline ARTUR CAMPOS CHEIB & Graduação & UFMG & $\begin{array}{l}\text { Administração } \\
\text { de Empresas }\end{array}$ & & & \\
\hline $\begin{array}{l}\text { CAROLINA RIENTE DE } \\
\text { ANDRADE }\end{array}$ & Doutorado & UFMG & Administração & $\begin{array}{l}\text { Administração de } \\
\text { Empresas }\end{array}$ & Professora & CEFET/MG \\
\hline $\begin{array}{l}\text { HUDSON FERNANDES } \\
\text { AMARAL }\end{array}$ & Doutorado & $\begin{array}{l}\text { Université } \\
\text { Pierre } \\
\text { Mendés } \\
\text { France } \\
\text { Grenoble II } \\
\end{array}$ & Administração & & Professor & UFMG \\
\hline $\begin{array}{l}\text { IVAN BECK } \\
\text { CKAGNAZAROFF }\end{array}$ & Doutorado & $\begin{array}{c}\text { Aston } \\
\text { University }\end{array}$ & Administração & $\begin{array}{l}\text { Administração } \\
\text { Pública }\end{array}$ & Professor & UFMG \\
\hline $\begin{array}{l}\text { JOSÉ ROBERTO } \\
\text { PEREIRA }\end{array}$ & Doutorado & UnB & Sociologia & $\begin{array}{l}\text { Sociologia Rural / } \\
\text { Sociologia do } \\
\text { Desenvolvimento }\end{array}$ & Professor & UFLA \\
\hline $\begin{array}{l}\text { MÁRIO } \\
\text { VASCONCELLOS } \\
\text { SOBRINHO }\end{array}$ & Doutorado & $\begin{array}{c}\text { University } \\
\text { of Wales } \\
\text { Swansea }\end{array}$ & $\begin{array}{c}\text { Estudos do } \\
\text { Desenvolvimento }\end{array}$ & & Professor & UFPA \\
\hline $\begin{array}{l}\text { MIGUEL PACÍFICO } \\
\text { FILHO }\end{array}$ & Doutorado & UNESP & História & & Professor & UFT \\
\hline $\begin{array}{l}\text { MIRIAN LÚCIA JÁCOME } \\
\text { MACHADO }\end{array}$ & Graduação & UFMG & $\begin{array}{l}\text { Administração } \\
\text { de Empresas }\end{array}$ & & & \\
\hline $\begin{array}{l}\text { REBECA DA ROCHA } \\
\text { GRANGEIRO }\end{array}$ & Doutorado & UFBA & Psicologia & $\begin{array}{l}\text { Psicologia do } \\
\text { Trabalho e } \\
\text { Organizacional }\end{array}$ & Professora & UFC \\
\hline $\begin{array}{l}\text { REZILDA RODRIGUES } \\
\text { OLIVEIRA }\end{array}$ & Doutorado & IUPERJ & Ciência Política & & Professora & UFRPE \\
\hline $\begin{array}{l}\text { SYLMARA LOPES } \\
\text { FRANCELINO } \\
\text { GONÇALVES-DIAS }\end{array}$ & Doutorado & $\begin{array}{l}\text { USP / } \\
\text { FGV-SP }\end{array}$ & Administração & $\begin{array}{l}\text { Administração de } \\
\text { Empresas / } \\
\text { Administração e } \\
\text { meio ambiente }\end{array}$ & Professora & USP \\
\hline
\end{tabular}

Fonte: elaborado pela autora com base na Plataforma Lattes

Em relação à regularidade de produção dos pesquisadores, notamos que na Rede de Pesquisadores dos Cadernos de Gestão Social a maioria é one-timer (30,20\%), seguida de $21,48 \%$ de continuantes, $20,13 \%$ de retirantes, $18,79 \%$ de transientes e $9,40 \%$ de entrantes. 
Tabela 47: Categorização dos Pesquisadores da Rede de Pesquisadores dos Cadernos de Gestão Social (CGS)

\begin{tabular}{cc}
\hline Categoria & $\begin{array}{c}\text { \% do total de autorias do } \\
\text { periódico }\end{array}$ \\
\hline Continuantes & $21,48 \%$ \\
Transientes & $18,79 \%$ \\
One-timers & $30,20 \%$ \\
Entrantes & $9,40 \%$ \\
Retirantes & $20,13 \%$ \\
\hline \multicolumn{2}{c}{ Fonte: elaborado pela autora } \\
\end{tabular}

Assim como a Nau Social, os Cadernos de Gestão Pública também são vinculados ao Centro Interdisciplinar de Desenvolvimento e Gestão Social (CIAGS) da UFBA e também conta com muitos pesquisadores da Rede de Pesquisadores de Gestão Social (RGS) no seu corpo editorial. Esses elementos tornam-se atrativos aos pesquisadores do campo da Gestão Social.

\subsection{Rede de Pesquisadores da Revista Interdisciplinar de Gestão Social (RIGS)}

A Revista Interdisciplinar de Gestão Social (RIGS) é uma publicação eletrônica, fundada em 2012, com periodicidade quadrimestral, vinculada ao Centro Interdisciplinar de Desenvolvimento e Gestão Social (CIAGS) da Escola de Administração da Universidade Federal da Bahia (UFBA). Considerando o período compreendido por esta pesquisa, analisamos 8 números publicados.

A Rede de Pesquisadores da Revista Interdisciplinar de Gestão Social (RIGS) é composta por 191 pesquisadores (vértices) e 245 ligações (arestas), sendo que 239 são únicas e 6 são repetidas. Do total de pesquisadores, 12,14\% deles publicaram apenas artigos sem coautoria. A densidade da rede é de 0,0133370. 
Figura 31: Rede de Pesquisadores da Revista Interdisciplinar de Gestão Social (RIGS)

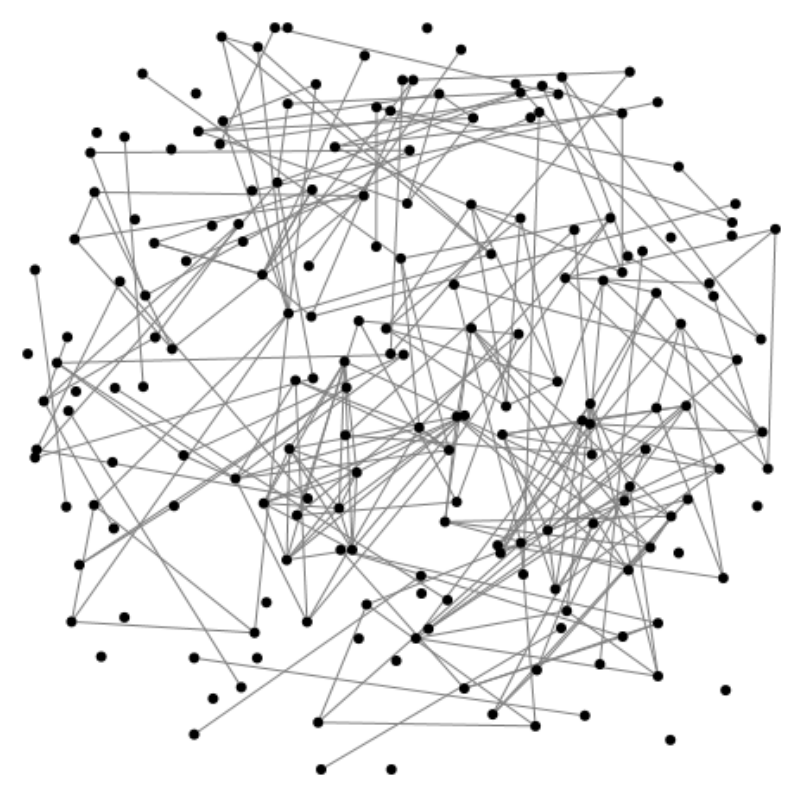

Fonte: elaborado pela autora

Neusa Rolita Cavedon é a pesquisadora mais prolífica da Rede de Pesquisadores da Revista Interdisciplinar de Gestão Social (RIGS), com um total de 5 artigos publicados. Na sequência temos Claudiani Waiandt, Fernando Gomes de Paiva Júnior, João Gualberto Moreira Vasconcellos, Marina Dantas de Figueiredo e Tânia Maria Diederichs Fischer, com 3 publicações cada um.

Tabela 48: Autores mais prolíficos da Rede de Pesquisadores da Revista Interdisciplinar de Gestão Social (RIGS)

\begin{tabular}{lc}
\hline \multicolumn{1}{c}{ Pesquisador } & $\mathbf{N}^{\mathbf{0}}$ de publicações \\
\hline NEUSA ROLITA CAVEDON & 5 \\
CLAUDIANI WAIANDT & 3 \\
FERNANDO GOMES DE PAIVA JÚNIOR & 3 \\
JOÃO GUALBERTO MOREIRA VASCONCELLOS & 3 \\
MARINA DANTAS DE FIGUEIREDO & 3 \\
TÂNIA MARIA DIEDERICHS FISCHER & 3 \\
\hline
\end{tabular}

Fonte: elaborado pela autora

Fernando Gomes de Paiva Júnior, além de estar entre os pesquisadores mais prolíficos, possui as maiores medidas de centralidade de grau (degree) e de intermediação (betweeneess). 
Em relação à centralidade de grau (degree), devemos apontar que excluímos da tabela 45 todos os pesquisadores one-timers e apresentamos as três maiores medidas, pois na quarta colocação estão empatados 14 pesquisadores. $\mathrm{Na}$ centralidade de intermediação (betweeneess), apresentamos 6 pesquisadores, já que Luiz Roberto Santos Moraes, Maria Lúcia Politano Álvares e Nicholas Carvalho de Almeida Costa estão empatados no terceiro lugar. Por fim, devemos ressaltar que todos os pesquisadores que apresentaram alguma medida de centralidade de autovetor (eigenvector) são one-timers e, por isso, os excluímos da análise.

Tabela 49: Medidas de centralidade da Rede de Pesquisadores da Revista Interdisciplinar de Gestão Social (RIGS)

\begin{tabular}{ll}
\hline \multicolumn{1}{c}{ Pesquisador } & Medida \\
\hline Centralidade de grau (degree) & \\
FERNANDO GOMES DE PAIVA JÚNIOR & 0,04211 \\
MARIA ELISABETE PEREIRA DOS SANTOS & 0,03684 \\
LUIZ ROBERTO SANTOS MORAES & 0,03158 \\
MARIA LÚCIA POLITANO ÁLVARES & 0,03158 \\
\hline Centralidade de intermediação (betweeneess) & \\
\hline FERNANDO GOMES DE PAIVA JÚNIOR & 0,00117 \\
MARIA ELISABETE PEREIRA DOS SANTOS & 0,00117 \\
NEUSA ROLITA CAVEDON & 0,00061 \\
LUIZ ROBERTO SANTOS MORAES & 0,00050 \\
MARIA LÚCIA POLITANO ÁLVARES & 0,00050 \\
NICHOLAS CARVALHO DE ALMEIDA COSTA & 0,00050 \\
\hline
\end{tabular}

Fonte: elaborado pela autora 
Figura 32: Representação gráfica da centralidade de grau (degree) e centralidade de intermediação (betweenness) da Rede de Pesquisadores da Revista Interdisciplinar de Gestão Social (RIGS)

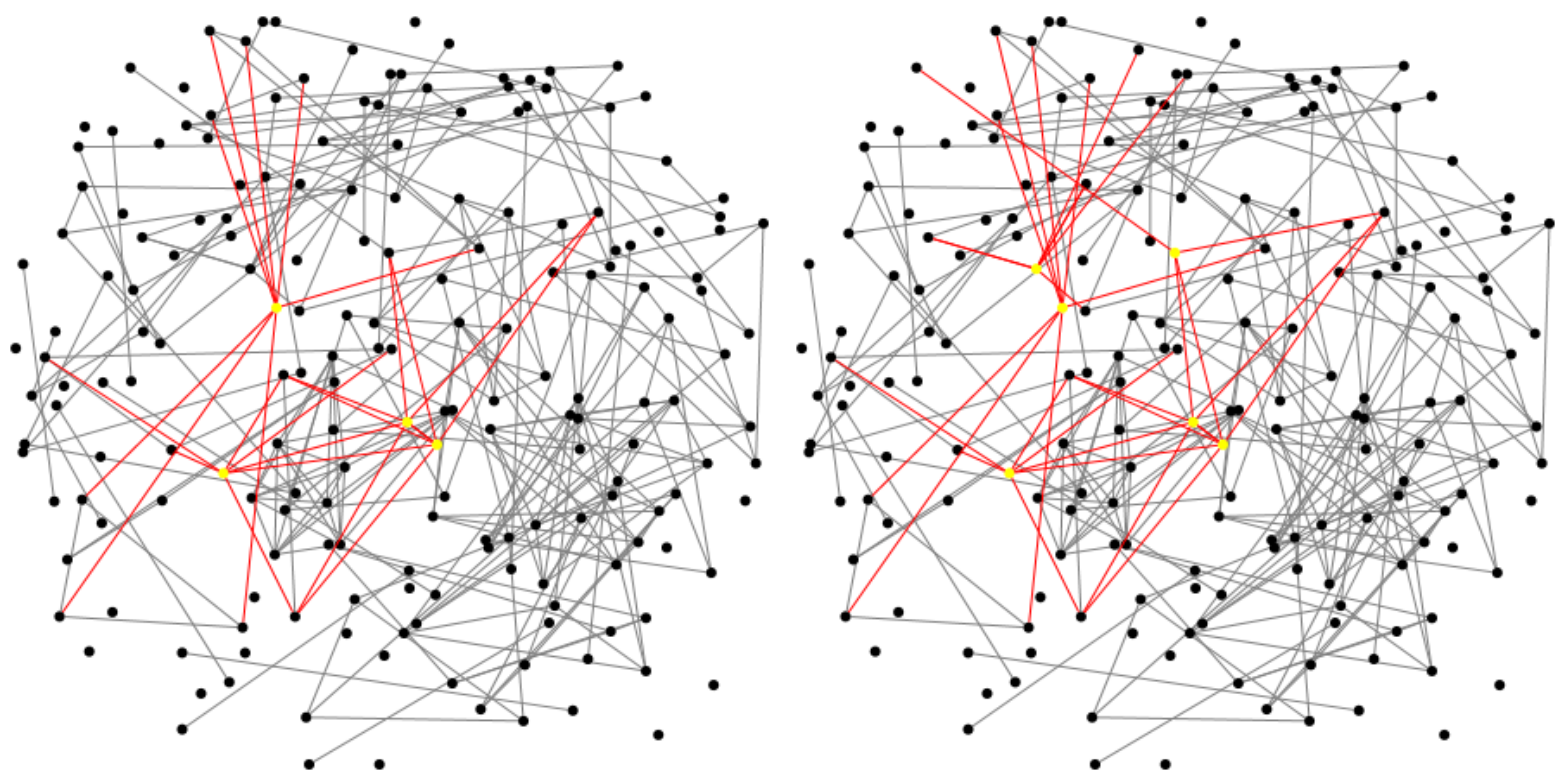

Fonte: elaborado pela autora

Duas instituições se destacam na formação acadêmica da Rede de Pesquisadores da Revista Interdisciplinar de Gestão Social (RIGS). São elas: Universidade Federal do Rio Grande do Sul (UFRGS) e Universidade Federal da Bahia (UFBA). Ambas são responsáveis pela titulação de $40 \%$ dos pesquisadores desta rede. Ademais, a Universidade Federal da Bahia é a instituição em que $40 \%$ dos pesquisadores possuem vinculação em relação à atuação profissional.

Quadro 27: Atributos dos principais autores da Rede de Pesquisadores da Revista Interdisciplinar de Gestão Social (RIGS)

\begin{tabular}{|l|c|c|c|c|c|c|}
\hline \multirow{2}{*}{ Pesquisador(a) } & \multicolumn{3}{|c|}{ Formação acadêmica } & \multicolumn{2}{c|}{ Atuação profissional } \\
\cline { 2 - 7 } & $\begin{array}{c}\text { Última } \\
\text { titulação }\end{array}$ & Instituição & Área & Subárea & $\begin{array}{c}\text { Vínculo } \\
\text { Institucional }\end{array}$ & Instituição \\
\hline $\begin{array}{l}\text { CLAUDIANI } \\
\text { WAIANDT }\end{array}$ & Doutorado & UFBA & Administração & Ensino & Professora & UFBA \\
\hline $\begin{array}{l}\text { FERNANDO GOMES } \\
\text { DE PAIVA JÚNIOR }\end{array}$ & Doutorado & UFMG & Administração & & Professor & UFPE \\
\hline
\end{tabular}




\begin{tabular}{|c|c|c|c|c|c|c|}
\hline $\begin{array}{l}\text { JOÃO GUALBERTO } \\
\text { MOREIRA } \\
\text { VASCONCELLOS }\end{array}$ & Doutorado & $\begin{array}{l}\text { Ecole des } \\
\text { Hautes } \\
\text { Études en } \\
\text { Sciences } \\
\text { Sociales } \\
\end{array}$ & Sociologia & & $\begin{array}{l}\text { Sócio Diretor de } \\
\text { Relacionamento }\end{array}$ & Futura \\
\hline $\begin{array}{l}\text { LUIZ ROBERTO } \\
\text { SANTOS MORAES }\end{array}$ & Doutorado & $\begin{array}{l}\text { University } \\
\text { of London }\end{array}$ & $\begin{array}{l}\text { Saúde } \\
\text { Coletiva }\end{array}$ & Epidemiologia & $\begin{array}{l}\text { Professor } \\
\text { Participante } \\
\text { Especial }\end{array}$ & UFBA \\
\hline $\begin{array}{l}\text { MARIA ELISABETE } \\
\text { PEREIRA DOS } \\
\text { SANTOS }\end{array}$ & Doutorado & UNICAMP & $\begin{array}{l}\text { Ciências } \\
\text { Sociais }\end{array}$ & & Professora & UFBA \\
\hline $\begin{array}{l}\text { MARIA LÚCIA } \\
\text { POLITANO ÁLVARES }\end{array}$ & Mestrado & UFBA & $\begin{array}{c}\text { Engenharia } \\
\text { Ambiental } \\
\text { Urbana }\end{array}$ & & $\begin{array}{l}\text { Engenheira } \\
\text { Projetista }\end{array}$ & $\begin{array}{c}\text { HIGESA / } \\
\text { GEOHIDRO } \\
\text { / EMBASA }\end{array}$ \\
\hline $\begin{array}{l}\text { MARINA DANTAS DE } \\
\text { FIGUEIREDO }\end{array}$ & Doutorado & UFRGS & Administração & & Professora & UNIFOR \\
\hline $\begin{array}{l}\text { NEUSA ROLITA } \\
\text { CAVEDON }\end{array}$ & Doutorado & UFRGS & Administração & $\begin{array}{c}\text { Administração } \\
\text { de Setores } \\
\text { Específicos }\end{array}$ & Professora & UFRGS \\
\hline $\begin{array}{l}\text { NICHOLAS } \\
\text { CARVALHO DE } \\
\text { ALMEIDA COSTA }\end{array}$ & Graduação & UNIJORGE & $\begin{array}{l}\text { Ciências } \\
\text { Biológicas }\end{array}$ & & Biólogo/Pesquisador & $\begin{array}{c}\text { Área } 1 \text { - } \\
\text { Faculdade } \\
\text { de Ciência e } \\
\text { Tecnologia }\end{array}$ \\
\hline $\begin{array}{l}\text { TÂNIA MARIA } \\
\text { DIEDERICHS FISCHER }\end{array}$ & Doutorado & USP & Administração & & Professora & UFBA \\
\hline
\end{tabular}

Fonte: elaborado pela autora com base na Plataforma Lattes

No tocante à regularidade de produção científica da Rede de Pesquisadores da Revista Interdisciplinar de Gestão Social (RIGS), destacamos que 35,98\% dos pesquisadores são onetimers, $26,17 \%$ são transientes, $16,36 \%$ são continuantes, $14,02 \%$ são retirantes e apenas $7,48 \%$ são entrantes.

Tabela 50: Categorização dos Pesquisadores da Rede de Pesquisadores da Revista Interdisciplinar de Gestão Social (RIGS)

\begin{tabular}{cc}
\hline Categoria & $\begin{array}{c}\text { \% do total de autorias do } \\
\text { periódico }\end{array}$ \\
\hline Continuantes & $16,36 \%$ \\
Transientes & $26,17 \%$ \\
One-timers & $35,98 \%$ \\
Entrantes & $7,48 \%$ \\
Retirantes & $14,02 \%$ \\
\hline
\end{tabular}

Fonte: elaborado pela autora 
A Revista Interdisciplinar de Gestão Social (RIGS), bem como os periódicos NAU Social e Cadernos de Gestão Social, é vinculada ao Centro Interdisciplinar de Desenvolvimento e Gestão Social (CIAGS) da UFBA. Isso pode explicar o alto número de pesquisadores vinculados a esta universidade.

\subsection{Considerações gerais sobre a análise dos resultados}

A análise global dos resultados, tratada na seção 4.1, mostrou que os eventos têm um peso significativo para a produção científica do campo da Gestão Social, pois representa 77\% do volume total. Ainda em relação ao volume da produção científica, notamos que alguns periódicos sofreram descontinuidade em alguns períodos, o que pode ter contribuído para sua menor participação no volume total da produção. Outro ponto que podemos destacar é que comparativamente às demais subáreas do Campo de Públicas (Administração Pública e Políticas Públicas), o campo da Gestão Social é o que apresenta o maior índice de colaboração e o menor índice de produtividade fracionada (artigos por autor). Ainda em relação à análise comparativa, o campo da Gestão Social é o que apresenta o maior percentual de pesquisadores continuantes.

Já a análise segmentada por evento e periódico indicou que o campo da Gestão Social é multidisciplinar, pois é composto por pesquisadores de diversas áreas de formação, como por exemplo: administração, sociologia, engenharia de produção, direito etc. No entanto, podemos notar uma prevalência da área de administração nos eventos, periódicos e na formação dos pesquisadores. A maioria maciça dos pesquisadores possuem doutorado que adquiriram, principalmente, pelas seguintes instituições: UFMG, USP, UFBA, UFSC e UFV. Ao analisar as instituições em que os pesquisadores estão vinculados atualmente, destacamos a UFV e a UFBA. Outro ponto que devemos ressaltar é como a relação entre orientador e orientando contribuiu para a formação da rede e para a inserção de novos autores na temática. Além disso, devemos ressaltar que os eventos e periódicos mantêm certa territorialidade, pois atraem pesquisadores da região em que os eventos são realizados ou da região em que a instituição responsável pelo periódico se localiza. 
O quadro 28 sintetiza em um espaço único as medidas de densidade das redes, o número de vértices total, o número de vértices com e sem coautoria, o número de arestas total, o número de arestas únicas e duplicadas e a distribuição dos pesquisadores entre as categorias de regularidade de produção (continuantes, transientes, one-timers, entrantes e retirantes).

Quadro 28: Comparação das medidas calculadas

\begin{tabular}{|c|c|c|c|c|c|c|c|c|c|c|c|c|}
\hline \multirow{2}{*}{ Rede } & \multirow{2}{*}{ Densidade } & \multicolumn{3}{|c|}{ Vértices } & \multicolumn{3}{|c|}{ Arestas } & \multicolumn{5}{|c|}{ Categoria } \\
\hline & & Total & $\begin{array}{c}\text { Com } \\
\text { coautoria }\end{array}$ & $\begin{array}{c}\text { Sem } \\
\text { coautoria }\end{array}$ & Total & Única & $\begin{array}{l}\text { Dupli- } \\
\text { cada }\end{array}$ & $\begin{array}{l}\text { Continu- } \\
\text { antes }\end{array}$ & $\begin{array}{c}\text { Transi- } \\
\text { entes }\end{array}$ & $\begin{array}{c}\text { One- } \\
\text { timers }\end{array}$ & $\begin{array}{l}\text { Entran- } \\
\text { tes }\end{array}$ & $\begin{array}{l}\text { Retiran- } \\
\text { tes }\end{array}$ \\
\hline RGPS & 0,0006604 & 4302 & $\begin{array}{c}3896 \\
(90,56 \%)\end{array}$ & $\begin{array}{c}406 \\
(9,44 \%)\end{array}$ & 7389 & 5274 & 2115 & $2,65 \%$ & $9,14 \%$ & $72,11 \%$ & $3,49 \%$ & $12,62 \%$ \\
\hline CISPL & 0,0021031 & 1139 & $\begin{array}{c}1015 \\
(89,11 \%)\end{array}$ & $\begin{array}{c}124 \\
(10,89 \%)\end{array}$ & 1466 & 1277 & 189 & $16,08 \%$ & $12,19 \%$ & $39,25 \%$ & $0,00 \%$ & $32,48 \%$ \\
\hline EMAPEGS & 0,0123450 & 191 & $\begin{array}{c}179 \\
(93,72 \%)\end{array}$ & $\begin{array}{c}12 \\
(6,28 \%)\end{array}$ & 228 & 220 & 8 & $14,72 \%$ & $7,36 \%$ & $51,95 \%$ & $25,97 \%$ & $0,00 \%$ \\
\hline EnANPAD & 0,0016664 & 1474 & $\begin{array}{c}1408 \\
(95,52 \%)\end{array}$ & $\begin{array}{c}66 \\
(4,48 \%)\end{array}$ & 1917 & 1717 & 200 & $14,24 \%$ & $18,94 \%$ & $44,49 \%$ & $4,39 \%$ & $17,93 \%$ \\
\hline ENAPEGS & 0,0022897 & 1197 & $\begin{array}{c}1099 \\
(91,81 \%)\end{array}$ & $\begin{array}{c}98 \\
(8,19 \%)\end{array}$ & 1884 & 1480 & 404 & $23,05 \%$ & $17,86 \%$ & $38,37 \%$ & $6,33 \%$ & $14,39 \%$ \\
\hline EnAPG & 0,0060036 & 375 & $\begin{array}{c}347 \\
(92,53 \%)\end{array}$ & $\begin{array}{c}28 \\
(7,47 \%)\end{array}$ & 436 & 408 & 28 & $20,09 \%$ & $16,03 \%$ & $37,92 \%$ & $2,71 \%$ & $23,25 \%$ \\
\hline APGS & 0,0154684 & 136 & $\begin{array}{c}124 \\
(91,18 \%)\end{array}$ & $\begin{array}{c}12 \\
(8,82 \%)\end{array}$ & 147 & 138 & 9 & $33,33 \%$ & $21,79 \%$ & $25,64 \%$ & $1,92 \%$ & $17,31 \%$ \\
\hline RAP & 0,0067295 & 290 & $\begin{array}{c}259 \\
(89,31 \%)\end{array}$ & $\begin{array}{c}31 \\
(10,69 \%)\end{array}$ & 289 & 275 & 14 & $15,02 \%$ & $19,17 \%$ & $43,77 \%$ & $2,56 \%$ & $19,49 \%$ \\
\hline RIGS & 0,0133370 & 191 & $\begin{array}{c}164 \\
(85,86 \%)\end{array}$ & $\begin{array}{c}27 \\
(12,14 \%)\end{array}$ & 245 & 239 & 6 & $16,36 \%$ & $26,17 \%$ & $35,98 \%$ & $7,48 \%$ & $14,02 \%$ \\
\hline $\begin{array}{l}\text { NAU } \\
\text { Social }\end{array}$ & 0,0080812 & 237 & $\begin{array}{c}168 \\
(70,89 \%)\end{array}$ & $\begin{array}{c}69 \\
(29,11 \%)\end{array}$ & 231 & 222 & 9 & $16,78 \%$ & $21,68 \%$ & $41,96 \%$ & $6,99 \%$ & $12,59 \%$ \\
\hline O\&S & 0,0130539 & 148 & $\begin{array}{c}135 \\
(91,22 \%)\end{array}$ & $\begin{array}{c}13 \\
(8,78 \%)\end{array}$ & 142 & 142 & 0 & $22,93 \%$ & $11,46 \%$ & $42,68 \%$ & $0,00 \%$ & $22,93 \%$ \\
\hline CGP\&C & 0,0165378 & 97 & $\begin{array}{c}72 \\
(74,23 \%)\end{array}$ & $\begin{array}{c}25 \\
(25,77 \%)\end{array}$ & 77 & 0 & 77 & $15,53 \%$ & $19,42 \%$ & $50,49 \%$ & $1,94 \%$ & $12,62 \%$ \\
\hline CGS & 0,0133458 & 139 & $\begin{array}{c}114 \\
(82,01 \%)\end{array}$ & $\begin{array}{c}25 \\
(17,99 \%)\end{array}$ & 128 & 128 & 0 & $21,48 \%$ & $18,79 \%$ & $30,20 \%$ & $9,40 \%$ & $20,13 \%$ \\
\hline $\begin{array}{l}\text { Cadernos } \\
\text { EBAPE.BR }\end{array}$ & 0,0104694 & 189 & $\begin{array}{c}172 \\
(91,01 \%)\end{array}$ & $\begin{array}{c}17 \\
(8,99 \%)\end{array}$ & 199 & 174 & 25 & $26,36 \%$ & $16,82 \%$ & $32,27 \%$ & $0,45 \%$ & $24,09 \%$ \\
\hline
\end{tabular}

Fonte: elaborado pela autora

Por fim, é importante dizer que os dados podem ser interpretados de diversas formas, dependendo do conhecimento e da área de formação e atuação de quem os está avaliando. 


\section{CONSIDERAÇÕES FINAIS}

O objetivo geral desta dissertação era mapear e construir a rede de produção científica do campo do saber em Gestão Social na última década (2005-2015). De grande medida, a coleta dos artigos científicos publicados nos periódicos e apresentados nos eventos e o posterior tratamento das informações permitiu uma possível radiografia da Rede de Pesquisadores de Gestão Social (RPGS) no país. Em relação aos objetivos específicos, podemos constatar que também foi possível identificar as principais características do campo da Gestão Social, no que diz respeito à formação acadêmica e vinculação institucional de seus pesquisadores mais prolíficos. A coleta e análise dos atributos dos principais pesquisadores evidenciou que o campo da Gestão Social é multidisciplinar, pois congrega pesquisadores com diversas áreas de formação, a saber: administração, sociologia, engenharia de produção, direito etc. Além disso, foi possível perceber o protagonismo das universidades mineiras e das universidades da região nordeste na ampliação e consolidação desse campo do saber nos últimos anos.

A evolução do campo por meio da rede de produção científica nos mostrou que os eventos possuem grande importância no volume total de artigos do campo, representando cerca de 2/3 (dois terços) do total da produção. Ainda em relação aos eventos, é necessário destacar a importância da criação do Encontro Nacional de Pesquisadores em Gestão Social que é responsável por uma parcela significativa da produção científica do campo, além de ser o evento específico de Gestão Social com maior regularidade e congregação dos principais pesquisadores. O cálculo dos índices, com base na produção científica do campo, nos mostrou que, em comparação com as demais subáreas do Campo de Públicas (Administração Pública e Políticas Públicas), o campo da Gestão Social se mostrou o mais colaborativo, com o índice de 2,35 autores por artigo e o com menor índice de produtividade fracionada com o número de 0,48 artigos por autor. Ainda tratando da produção científica, notamos que das três subáreas do Campo de Públicas, o campo da Gestão Social apresenta o maior percentual de pesquisadores continuantes, representado por 2,65\% do total. Conforme dissemos no capítulo de análise dos resultados, isso pode ser consequência da existência da Rede de Pesquisadores de Gestão Social (RGS) composta pelos principais pesquisadores da área que vem debatendo e alimentando a pesquisa em Gestão Social na última década. 
O último objetivo específico proposto era contribuir com o debate em torno da construção da identidade da área de pesquisa em Gestão Social. A elaboração da rede de pesquisadores, o levantamento dos atributos dos principais pesquisadores e a análise da produção científica dão elementos para uma análise mais aprofundada do campo, inclusive no sentido de colaborar com a discussão da identidade do campo da Gestão Social. Entretanto, nessa fase da pesquisa o foco foi mais quantitativo e, portanto, apresentou limitações em relação a uma análise qualitativa mais pormenorizada que pudesse contribuir para o atingimento de tal objetivo.

É importante frisar que essa dissertação não tinha a pretensão de aprofundar o debate proposto por Cançado (2011) e Araújo (2012) sobre se a Gestão Social pode ser considerada como um campo de conhecimento consolidado, bem como discorrer sobre as críticas que a abordagem da Gestão Social sofre, ainda que esses tópicos foram abordados - brevemente - no trabalho. Entendemos que tais tópicos são de suma importância, mas o objetivo do estudo no capítulo 2 foi traçar apenas um panorama das principais discussões e dos elementos basais, para auxiliar na compreensão do campo da Gestão Social, sem a pretensão de tornar essa análise o ponto central da dissertação.

Por fim, é necessário apontar que algumas das limitações da pesquisa, citadas acima, podem ser alvo da agenda de pesquisa futura. A partir da coleta dos dados e da construção das redes de pesquisa, é possível avançar para a próxima fase da investigação que deve englobar:

a) O aprofundamento e análise crítica da revisão bibliográfica, por meio da abordagem mais pormenorizada dos aspectos tratados brevemente pelo presente estudo e reflexão crítica sobre toda a bibliografia tratada;

b) A criação de um referencial teórico, que levante conceitos chave para o desenvolvimento do trabalho e análise dos resultados, e que também auxiliem na criação de categorias analíticas;

c) A análise das temáticas tratadas na produção científica, o que contribuirá para o debate em torno da construção da identidade da área de pesquisa em Gestão Social;

d) Um estudo mais aprofundado sobre a endogenia dos periódicos e dos eventos para verificar a tendência identificada neste trabalho, o qual apontou que os eventos e periódicos atraíam pesquisadores das universidades responsáveis pelos eventos e/ou publicações; 
e) e a análise qualificada das redes, que permitirá a verificação de aspectos importantes sobre a estrutura e características das redes. Para isso, contaremos com apoio de pesquisadores do campo da Gestão Social e de outras áreas que possam contribuir com tal análise. 


\section{REFERÊNCIAS BIBLIOGRÁFICAS}

ANJOS, G. C. B.. Procedimentos Metodológicos em Pesquisas Sobre Gestão Social: Um Estudo Bibliométrico dos Anais do ENANPAD e ENAPG no Período de 2001 a 2011. In: VIII ENAPEGS - Encontro Nacional de Pesquisadores em Gestão Social, 2014, Cachoeira/BA. Anais do VIII ENAPEGS - Encontro Nacional de Pesquisadores em Gestão Social, 2014.

ARAÚJO, E. T. (In)consistências da Gestão Social e seus processos de formação: um campo em construção. Tese de Doutorado em Serviço Social. Pontifícia Universidade Católica de São Paulo, Programa de Estudos Pós-graduados em Serviço Social, São Paulo: PUC-SP, 2012.

- Gestão Social. In: BOULlOSA, R. F. (org.). Dicionário para a formação em Gestão Social. Salvador: CIAGS/UFBA, 2014. p. 85-90.

BORGES, G. F.; et al. Gestão Social no "Divã": Uma Análise dos Estudos Publicados em Periódicos Nacionais entre 2001 e 2011. In: Colóquio Internacional sobre Poder Local, 12, Salvador. Anais..., Salvador: CIAGS/UFBA, 2012.

BOULLOSA, R. F. ; SCHOMMER, P. . Limites da Natureza da Inovação ou Qual o futuro da Gestão Social?. In: EnANPAD, XXXII, 2008, Rio de Janeiro. Anais..., Rio de Janeiro: 2008.

Gestão Social: Caso de Inovação em Políticas Públicas ou mais um Enigma de Lampedusa? In: ENAPEGS - Encontro Nacional de Pesquisadores em Gestão Social, III, 2009, Juazeiro/Ba e Petrolina/Pe. Anais..., Petrolina/PE : NIGS/UNIVASF, 2009. v. 1.p. 1-16.

BOUllosA, R. F.. Dicionário para a Formação em Gestão Social. 1. Ed. Salvador: Editora CIAGS, 2014. v. 1. 210p .

BOURDIEU, P. O campo científico. In: ORTIZ, R. Pierre Bourdieu: sociologia. São Paulo: Ática,1983.

BRAUN, T., GLÄNZEL, W.; SCHUBERT, A. Publication and cooperation patterns of the authors of neuroscience journals. Scientometrics, v. 51, n. 3, p. 499-510, 2001.

BRESSER-PEREIRA, C.. Réplica: comparação impossível. Rev. adm. empres., São Paulo, v. 45, n. 1, p. 50-51, mar. 2005. Disponível em $<$ http://www.scielo.br/scielo.php?script=sci_arttext\&pid=S0034-

75902005000100006\&lng=pt\&nrm=iso>. Acessado em 26 abr. 2016. 
CANÇADO, A. C. Fundamentos teóricos da Gestão Social. 2011. Tese (Doutorado em Administração), Universidade Federal de Lavras, Lavras. 2011.

Gestão Social: um debate para a construção do campo. NAU Social, v. 4, p. 191-209, 2013.

Gestão Social. In: BOULlOSA, R. F. (org.). Dicionário para a formação em Gestão Social. Salvador: CIAGS/UFBA, 2014. p. 80-84.

CANÇADO, A. C. et al.. Gestão Social: conhecimento e produção científica nos ENAPEGS 2007-2010. Administração Pública e Gestão Social, v. 3, n. 2, 2011. Disponível em: < http://www.apgs.ufv.br/index.php/apgs/article/view/59\#.VHN-5jTF-oM>. Acesso em 24 de nov. 2014.

CANÇADO, A. C.; PINHEIRO, L. S.. Gestão Social: uma análise comparada da produção científica nos ENAPEGS 2007-2013. Revista Interdisciplinar de Gestão Social, v. 3, n. 3, 2014. Disponível em: < http://www.rigs.ufba.br/pdfs/RIGS_v3_n3_art1.pdf>. Acesso em 24 de nov. 2014.

CANCADO, A. C.; TENORIO, F. G.; PEREIRA, J. R.. Gestão Social: reflexões teóricas e conceituais. Cad. EBAPE.BR, Rio de Janeiro, v. 9, n. 3, p. 681-703, set. 2011. Disponível em <http://www.scielo.br/scielo.php?script=sci_arttext\&pid=S167939512011000300002\&lng=pt\&nrm=iso>. Acessado em 26 abr. 2016.

CANÇADO, A. C; PEREIRA, J. R.; TENÓRIO, F. G. Gestão Social: epistemologia de um paradigma. Curitiba: CRV, 2013, 216p.

CARRION, R. S. M.; GARAY, A.. Organizações Privadas Sem Fins Lucrativos: a Participação do Mercado no Terceiro Setor. Tempo Social. Revista de Sociologia da USP, São Paulo, v. 12, n.2, p. 237-255, 2000.

CARTA DE BALNEÁRIO CAMBORIÚ. In: Encontro Nacional dos Estudantes de Administração Pública - ENEAP, IX, 2010, Balneário Camboriú, 2010. Disponível em: <https://psigma.files.wordpress.com/2010/08/carta-de-bal_-camboriu.pdf>

CENTRO LATINOAMERICANO DE ADMINISTRACIÓN PARA EL DESARROLLO CLAD. Gestión Pública Iberoamericana para el siglo XXI. In: Reunión Ordinaria del Consejo Directivo del CLAD, XL, Santo Domingo, Republica Dominicana, 2010.

COELHO, F. S.. Prefácio. Gestão Social: epistemologia de um paradigma. 2. ed. Curitiba: CRV, 2015. v. 1. 218p 
DENHARDT, R. B. Teorias da administração pública. São Paulo: Cengage Learning, 2012.

DOWBOR, L. O que é poder local?. São Paulo: Brasiliense, 1994.

A Gestão Social em busca de paradigmas. In: Elizabeth de Melo Rico; Raquel Raichelis. (Org.). Gestão Social - uma questão de debate. São Paulo: EDUC/IEE (Insituto de estudos Especiais da PUC-SP), 1999.

FADUL, É. et al . Administração pública no Brasil: reflexões sobre o campo do saber a partir da Divisão Acadêmica da Associação Nacional de Pós-Graduação e Pesquisa em Administração (2009-2013). Revista de Administração Pública, Rio de Janeiro, v.48, n.5, out. $2014 . \quad$ Disponível em: <http://www.scielo.br/scielo.php?script=sci_arttext\&pid=S0034-

$76122014000500012 \& \operatorname{lng}=$ pt\&nrm=iso $>$. Acesso em 20 de jan. 2015.

FARAH, M. F. S. Administração Pública e Políticas Públicas. Revista de Administração Pública, Rio de Janeiro - FGV, v. 3, n. 45, p. 813-836, 2011.

FISCHER, T.. Poderes locais, desenvolvimento e gestão: introdução a uma agenda. In: FISCHER, T. (Org.). Gestão do desenvolvimento e poderes locais: marcos teóricos e avaliação. Salvador: Casa da Qualidade, 2002. p. 12-32.

FISCHER, Rosa Maria. Estado, Mercado e Terceiro Setor: uma análise conceitual das parcerias intersetoriais. Revista de Administração (FEA-USP), São Paulo, v. 40, n.1, p. 5$18,2005$.

FRANÇA FILHO, G. C; DZIMIRA, S.. Economia solidária e dádiva. Organizações e Sociedade, Salvador - Bahia - Brasil, v. 06, n.14, p. 141-183, 1999.

FRANÇA FILHO, G. C. Definindo a Gestão Social. In: SILVA JÚNIOR, Jeová Torres; MÂSIHET, Rogério Teixeira (Org.). Gestão Social: práticas em debate, teorias em construção. Fortaleza: Imprensa Universitária, 2008. v. 1, p. 26-37.

GIL, A. C. Métodos e Técnicas de Pesquisa Social. São Paulo: Atlas, 2008.

GRANGEIRO, R. R.; PINTO, A.M.G ; VINHAS, F.D.. Redes de Colaboração Científica: Uma Análise das Publicações do Encontro Nacional de Pesquisadores em Gestão Social. Cadernos Gestão Social, v. 4, p. 163-180, 2013. 
GUARIDO FILHO, E. R.. A construção da teoria institucional nos estudos organizacionais no Brasil: o período 1993-2007. 2008. 316p. Tese (Doutorado em Administração). Universidade Federal do Paraná (UFPR). Curitiba.2008.

HEIDEMANN, F. G.; SALM, J. F. (Orgs). Políticas públicas e desenvolvimento: bases epistemológicas e modelos de análise. Brasília: Editora Universidade de Brasilia, 2009. 340 p.

HOCAYEN-DA-SILVA, A. J.; ROSSONI, L.; FERREIRA JUNIOR, I.. Administração pública e Gestão Social: a produção científica brasileira entre 2000 e 2005. Revista de Administração Pública, Rio de Janeiro, v. 42, n. 4, ago. 2008. Disponível em: $<$ http://www.scielo.br/scielo.php?script=sci_arttext\&pid=S0034-

$76122008000400002 \& \operatorname{lng}=$ en\&nrm=iso $>$. Acesso em 24 de nov. 2014.

IIZUKA, E. S.; JUNQUEIRA, L. A. P.. Produção Acadêmica em Gestão Social: visita aos Anais dos ENAPEGS de 2007 a 2012. RGSA: Revista de Gestão Social e Ambiental, v. 7, n. 2, 2013. Disponível em: <http://www.revistargsa.org/rgsa/article/view/651/pdf_49>. Acesso em 24 de nov. 2014.

JUNQUEIRA, L. A. P.. Intersetorialidade, transetorialidade e redes sociais na saúde. RAP. Revista Brasileira de Administração Pública, Rio de Janeiro - RJ, v. 34, n.6, p. 35-45, 2000.

Apresentação do $\mathrm{N}^{\circ}$ especial da Revista de administração Pública Intersetorialidade e Redes sociais. RAP. Revista Brasileira de Administração Pública, Rio de Janeiro, v. 34, n.6, p. 7-10, 2000.

MARTINS, S. M. A Construção do Conhecimento Científico no Campo de Gestão de Operações no Brasil: uma análise sob a ótica de Redes Sociais do período 1997-2008. Dissertação (Mestrado em Administração de Empresas), Fundação Getúlio Vargas, São Paulo. 2009.

MENDONCA, P. M. E.; GONCALVES-DIAS, S. L. F.; JUNQUEIRA, L. A. P.. Gestão Social: notícias sobre o campo de estudos e práticas a partir das interações e debates do VI Enapegs. Revista de Administração Pública, Rio de Janeiro , v. 46, n. 5, out. 2012. Disponível em: <http://www.scielo.br/scielo.php?script=sci_arttext\&pid=S0034$76122012000500010 \& \operatorname{lng}=e n \& n r m=i s o>$. Acesso em 24 de nov. 2014.

PAES DE PAULA, A. P.. Administração pública brasileira entre o gerencialismo e a Gestão Social. Revista de Administração de Empresas, São Paulo, v. 45, n. Disponível em: 
<http://www.scielo.br/scielo.php?script=sci_arttext\&pid=S0034-

$75902005000100005 \& \operatorname{lng}=$ en\&nrm=iso>. Acesso em 24 de nov. 2014.

PEREIRA, J. P.; RIGATTO, S. H.. Gestão Social de Políticas Públicas no Contexto das Relações Entre Estado e Sociedade Moderna. In: PEREIRA, J. P. (org.). Gestão Social de Políticas Públicas. Lavras: Ed. UFLA, 2011. 234 p.

PINHO, J. A. G. de. Gestão social: conceituando e discutindo os limites e possibilidades reais na sociedade brasileira. In RIGO, A. S.; SILVA JÚNIOR, J. T.; SCHOMMER, P. C.; CANÇADO, A. C. Gestão Social e Políticas Públicas de Desenvolvimento: Ações, Articulações e Agenda. Recife: UNIVASF, 2009. 456 p.

PINHO, J. A. G. de; SANTOS, E. P.. Aporias tem Torno do Conceito de Gestão Social: dilemas teóricos e políticos. In: EnANPAD, XXXVII, 2013, Rio de Janeiro. Anais..., Rio de Janeiro, 2013.

PIRES, V., et al. Dossiê - Campo de Públicas no Brasil: definição, movimento constitutivo e desafios atuais. Administração Pública e Gestão Social, v. 6, n. 3, jul. 2014. Disponível em: <http://www.apgs.ufv.br/index.php/apgs/article/view/719/371>. Acesso em 24 de nov. 2014.

SILVA, V. C.. Uma Análise do Campo do Saber em Administração Pública no Brasil (20002010) pela Modelagem de Redes Sociais. 2012. 176 p. Tese (Mestrado em Modelagem em Sistemas Complexos). Universidade de São Paulo. São Paulo. 2012

SOUZA, C. Políticas Públicas: Uma revisão da literatura. Sociologias, Porto Alegre, n. 16, 2003.

TENÓRIO, F. G., Gestão Social: uma perspectiva conceitual. Revista de Administração Pública, Rio de Janeiro, v.32, n.5, set/out. 1998. Disponível em: <http://bibliotecadigital.fgv.br/ojs/index.php/rap/article/viewFile/7754/6346>. Acesso em 24 de nov. 2014.

Questão, Ijuí, v. 3, n. 5, 2005. Disponível em: $<$ https://www.revistas.unijui.edu.br/index.php/desenvolvimentoemquestao/article/download/1 08/65>. Acesso em 24 de nov. 2014.

Gestão Social: uma réplica. In: RIGO, A. S.; SILVA JÚNIOR, J. T.; SCHOMMER, P. C.; CANÇADO, A. C.. Gestão Social e Políticas Públicas de Desenvolvimento: Ações, Articulações e Agenda. Recife: UNIVASF, 2010. 
TROTTMANN, P. A Produção Científica Em Políticas Públicas No Brasil: Uma Análise Sob a Ótica de Redes Sociais. 2012. 219 p. Tese (Mestrado em Modelagem em Sistemas Complexos). Universidade de São Paulo. São Paulo. 2012

WASSERMAN, S.; FAUST, K. Social network analysis: methods and applications. Cambridge: Cambridge University Press, 1994. 


\section{ANEXO}

Lista de pesquisadores classificados como continuantes na Rede de Pesquisadores de Gestão Social (RPGS), durante o período de 2005 a 2015.

ABDON SILVA RIBEIRO DA CUNHA AFONSO AUGUSTO TEIXEIRA DE FREITAS DE CARVALHO LIMA AIRTON CARDOSO CANÇADO ALAIR FERREIRA DE FREITAS ALEXANDRE DE PÁDUA CARRIERI ALMIRALVA FERRAZ GOMES ANA ALICE VILAS BOAS ANA CAROLINA GUERRA ANA MARIA ALBUQUERQUE VASCONCELLOS ANA PAULA PAES DE PAULA ANA SÍLVIA ROCHA IPIRANGA ANDRÉA LEITE RODRIGUES ARIÁDNE SCALFONI RIGO ARLINDO CARVALHO ROCHA ARMINDO DOS SANTOS DE SOUSA TEODÓSIO

ÁUREO MAGNO GASPAR PINTO BENILSON BORINELLI

BRUNO TAVARES

CARLOS ALBERTO GONÇALVES CARLOS EDUARDO GUERRA SILVA CÍNTIA RODRIGUES DE OLIVEIRA MEDEIROS

CLÁUDIA DE SOUZA PASSADOR DANIEL CALBINO PINHEIRO

DEISE LUIZA DA SILVA FERRAZ DIMITRI AUGUSTO DA CUNHA TOLEDO DUNIA COMERLATTO EDGILSON TAVARES DE ARAÚJO EDILEUSA GODÓI DE SOUSA EDSON ARLINDO SILVA EDSON SADAO IIZUKA EDUARDO VIVIAN DA CUNHA ELIANE SALETE FILIPPIN ELOÍSA HELENA DE SOUZA CABRAL ÉLVIA MIRIAN CAVALCANTI FADUL EUGÊNIO ÁVILA PEDROZO FABIANO MAURY RAUPP FABIO BITTENCOURT MEIRA FELIPE BARBOSA ZANI FERNANDO GOMES DE PAIVA JÚNIOR FERNANDO GUILHERME TENÓRIO FLÁVIA DE PAULA DUQUE BRASIL FLÁVIA LUCIANA NAVES MAFRA GABRIELA DE BRELÀZ GUSTAVO MELO SILVA
HÉLIO ARTHUR REIS IRIGARAY HILKA PELIZZA VIER MACHADO IVAN BECK CKAGNAZAROFF JACQUES DEMAJOROVIC JEOVÁ TORRES SILVA JÚNIOR JOÃO LUIZ PASSADOR JOSÉ ANTÔNIO GOMES DE PINHO JOSÉ CARLOS LÁZARO DA SILVA FILHO JOSÉ CÉLIO SILVEIRA ANDRADE JOSÉ RAIMUNDO CORDEIRO NETO JOSÉ ROBERTO PEREIRA JÚLIO CESAR ANDRADE DE ABREU JÚNIA DE FÁTIMA DO CARMO GUERRA LAMOUNIER ERTHAL VILLELA LUCIANO ANTONIO PRATES JUNQUEIRA

LUCIANO MUNCK

LUIS FELIPE NASCIMENTO

LUIZ ALEX SILVA SARAIVA LUIZ ROBERTO ALVES LUIZA REIS TEIXEIRA LYDIA MARIA PINTO BRITO MARCO ANTONIO CARVALHO TEIXEIRA

MARCO AURÉLIO MARQUES FERREIRA MARIA AMÉLIA JUNDURIAN CORÁ MARIA CAROLINA MARTINEZ ANDION MARIA ELISABETE PEREIRA DOS SANTOS

MARIO PRESTES MONZONI NETO MÁRIO VASCONCELLOS SOBRINHO MARTA FERREIRA SANTOS FARAH MÔNICA CAVALCANTI SÁ DE ABREU MOZAR JOSÉ DE BRITO NEUSA ROLITA CAVEDON PATRÍCIA APARECIDA FERREIRA PAULA CHIES SCHOMMER RAFAEL BORIM DE SOUZA ROSANA DE FREITAS BOULLOSA SABRINA SOARES DA SILVA SÉRGIO LUÍS ALLEBRANDT TÂNIA MARIA DIEDERICHS FISCHER TÂNIA NUNES DA SILVA THIAGO FERREIRA DIAS VALÉRIA GIANNELLA ALVES VÂNIA APARECIDA REZENDE DE OLIVEIRA 
Lista de pesquisadores classificados como transientes na Rede de Pesquisadores de Gestão Social (RPGS), durante o período de 2005 a 2015.

ADELAIDE MARIA COELHO BAÊTA ADILENE GONÇALVES QUARESMA ADÍLIO RENÊ ALMEIDA MIRANDA ADILSON FERREIRA FARIA ADRIANA NOGUEIRA VIEIRA LIMA ADRIANO LEAL BRUNI ADRIEL RODRIGUES DE OLIVEIRA ALAN FERREIRA DE FREITAS ALESSANDRA DEBONE DE SOUSA ALEX PIZZIO DA SILVA ALEXANDRE LIMA BAIÃO ALEXANDRE MATOS DRUMOND ALICE RODRIGUES BORGES LAZARONI ALINE LOURENÇO DE OLIVEIRA ALINE PEREIRA SALES

ALKETA PECI

ALLAN CLAUDIUS QUEIROZ BARBOSA ALMOG GRINER

ÁLVARO ESCRIVÃO JR.

AMBROZINA ABREU PEREIRA SILVA

ANA CAROLINA DE OLIVEIRA

ANA CECÍLIA FEITOSA DE

VASCONCELOS

ANA CRISTINA DE OLIVEIRA

TELÉSFORO

ANA LÚCIA GUEDES

ANA LÚCIA MAGRI LOPES

ANA MARIA MALIK

ANA PAULA RODRIGUES DINIZ

ANA RITA PINHEIRO DE FREITAS

ANDERSON DE OLIVEIRA REIS

ANDERSON RAFAEL NASCIMENTO

ANDRÉ LUIS ROCHA DE SOUZA

ANDRÉ LUIZ FISCHER

ANDREA CARDOSO VENTURA

ANDREA PAULA SEGATTO

ANETE ALBERTON

ANNA LAURA TEIXEIRA DE ALMEIDA

ANNY KARINE DE MEDEIROS

ANTONIO CARLOS SILVA COSTA

ANTONIO COSTA SILVA JUNIOR

ANTÔNIO MOREIRA CARVALHO NETO

ANTONIO SÉRGIO ARAUJO FERNANDES

ARILDA SCHMIDT GODOY

AUGUSTO CÉZAR DE AQUINO CABRAL

ÁURIO LÚCIO LEOCÁDIO DA SILVA

BARBARA CALÇADO LOPES MARTINS

BÁRBARA GALLELI

BENILDA REGINA PAIVA DE BRITO

BERNARDO CARLOS SPAULONCI

CHIACHIA MATOS DE OLIVEIRA
BIANCA BURDINI MAZZEI

BIBIANA VOLKMER MARTINS

BRENO AUGUSTO DINIZ PEREIRA

BRENO DE PAULA ANDRADE CRUZ

BRUNO LAZZAROTTI DINIZ COSTA

CAIO CÉSAR DE MEDEIROS COSTA

CARINE DE ALMEIDA VIEIRA

CARLA BRONZO LADEIRA CARNEIRO

CARLOS ALBERTO FRANTZ DOS

SANTOS

CARLOS ALBERTO GRESPAN BONACIM

CARLOS CESAR GARCIA FREITAS

CARLOS DOUGLAS DE SOUSA

OLIVEIRA

CARLOS EDUARDO CAVALCANTE

CARLOS EDUARDO JUSTEN

CARLOS FREDERICO BOM KRAEMER

CARLOS RICARDO ROSSETTO

CARLOS ROBERTO SANCHEZ MILANI

CARMEN PINEDA NEBOT

CAROLINA PIWOWARCZYK REIS

CAROLINA WÜNSCH MARCELINO

CECÍLIA OLIVIERI

CELME TORRES FERREIRA DA COSTA

CHARBEL JOSÉ CHIAPPETTA JABBOUR

CÍNTIA BINCOLETO FAZION

CLANDIA MAFFINI GOMES

CLAUDIA DA SILVA JORDÃO

CLAUDIO ROBERTO MARQUES GURGEL

CLAUDIO SONAGLIO ALBANO

CLAUDIO ZANCAN

CLEBER JOSÉ CUNHA DUTRA

CLENIA DE MATTIA

CLEONÍSIA ALVES RODRIGUES DO

VALE

CLERILEI APARECIDA BIER

CRISTIAN EUGENIO ORELLANA PINO

CRISTIANA FERNANDES DE MÜYLDER

CRISTIANE BETANHO

CRISTIELE TOMM DECKERT

DAIANE MEDEIROS ROQUE

DANIEL LEITE MESQUITA

DANIEL REIS ARMOND DE MELO

DANIELE CARDOSO DO NASCIMENTO

DANIELLE REGINA ULLRICH

DANIELLE SOARES PAIVA

DANY FLÁVIO TONELLI

DARCY MITIKO MORI HANASHIRO

DÉBORA COUTINHO PASCHOAL

DOURADO

DEBORAH OLIVEIRA SANTOS ABDALA 
DEISIANE DOS SANTOS DELFINO

DENISE CRISTINA MOMO

DENISE DE CASTRO PEREIRA

DENIZE GRZYBOVSKI

DEONIR DE TONI

DIETER RUGARD SIEDENBERG

DIOGO HENRIQUE HELAL

DORALIZA AUXILIADORA ABRANCHES

MONTEIRO

DORIANA DAROIT

DOUGLAS WEGNER

EDUARDO DE CAMARGO OLIVA

EDUARDO DE LIMA CALDAS

EDUARDO GRANHA MAGALHÃES

GOMES

EDUARDO GUSMÃO DA COSTA

EDUARDO JOSÉ GRIN

ELINALDO LEAL SANTOS

ELISA YOSHIE ICHIKAWA

ELISABETH CAVALCANTE DOS SANTOS

ELISETE DAHMER PFITSCHER

ELISSON ALBERTO TAVARES ARAÚJO

ELIZABETH APARECIDA DA COSTA

ALMEIDA

ELIZETE APARECIDA DE MAGALHÃES

ELNIVAN MOREIRA DE SOUZA

ELOISIO MOULIN DE SOUZA

ELY LAUREANO PAIVA

EMANUEL DHEISON DOS SANTOS

PENHA

EMILIANA DEBETIR

EMMANUELLE FONSECA MARINHO DE

ANIAS DALTRO

ENIO LUIZ SPANIOL

ERICA MONTEIRO DO BOMFIM BORDIN

ÉRIKA LOUREIRO BORBA

EVELIZE WELZEL

EWERTON MARTINHO VILAS BOAS

FÁBIA CALASANS

FABIANE LOUISE BITENCOURT PINTO

FABIANO LARENTIS

FABÍOLA DAPUZZO VINHAS

FABRÍCIO MOLICA DE MENDONÇA

FABRÍCIO NASCIMENTO DA CRUZ

FAGNER CORDEIRO DANTAS

FELIPE MARQUES CARABETTI GONTIJO

FERNANDA CRISTINA DA SILVA

FERNANDA DA VITÓRIA LEBARCKY

FERNANDA FERNANDES GURGEL

FERNANDA HENRIQUE CUPERTINO

ALCÂNTARA

FERNANDA MITSUE SOARES ONUMA

FERNANDA SANTINELLI
FERNANDO BURGOS PIMENTEL DOS

SANTOS

FERNANDO DO AMARAL NOGUEIRA

FERNANDO LUIZ ABRUCIO

FERNANDO NOGUEIRA

FLÁVIA LUCIANE SCHERER

FLAVIA REGINA PANAZZOLO MACIEL

FLAVIO HOURNEAUX JUNIOR

FLÁVIO SANTOS NOVAES

FRANCISCO CORREIA DE OLIVEIRA

FRANCISCO RANIERE MOREIRA DA

SILVA

FRANCIVALDO DOS SANTOS

ALBUQUERQUE

FRANCIVALDO DOS SANTOS

NASCIMENTO

FREDERICO FERREIRA DE OLIVEIRA

GABRIEL SPERANDIO MILAN

GERALDO CÉSAR DIEGUES

GESINALDO ATAIIDE CÂNDIDO

GÉSSICA MATHIAS DINIZ

GLENER ALVARENGA MIZAEL

GRAZIELA DIAS ALPERSTEDT

GRAZIELA DONÁRIO DE AZEVEDO

GRAZIELLA MARIA COMINI

GUILHERME DORNELAS CAMARA

GUINEVERRE ALVAREZ MACHADO DE

MELO GOMES

HAMILTON LUIZ CORRÊA

HELENA KUERTEN DE SALLES

HELGA MIDORI IWAMOTO

HUDSON SANTOS DA SILVA

HUGO NARITOMI

IAGO ITÃ DE ALMEIDA PEREIRA

INGRID WINKLER

ISABEL CRISTINA DA SILVA

ISABELA BRAGA DA MATTA

ISAK KRUGLIANSKAS

ITAIR DE OLIVEIRA ARAÚJO

ÍTALO ANDERSON TAUMATURGO DOS

SANTOS

IURI GAVRONSKI

IVES ROMERO TAVARES DO

NASCIMENTO

JACKELINE AMANTINO DE ANDRADE

JAIR NASCIMENTO SANTOS

JANETTE BRUNSTEIN

JÁSSIO PEREIRA DE MEDEIROS

JAYSA ELIUDE AGUIAR DOS SANTOS

JEAN PIERRE CHASSOT

JEFERSON DAHMER

JOÃO BATISTA REZENDE

JOÃO MAURÍCIO GAMA BOAVENTURA

JOÃO MORAES SOBRINHO 
JOAQUIM RUBENS FONTES FILHO

JORDANA MARQUES KNEIPP

JORGE ALEXANDRE BARBOSA NEVES

JORGE BRAUN NETO

JORGE ONEIDE SAUSEN

JORGE RENATO DE SOUZA

VERSCHOORE FILHO

JORGE SÜNDERMANN

JOSÉ EDUARDO FERREIRA LOPES

JOSÉ FRANCISCO DE CARVALHO

REZENDE

JOSÉ HENRIQUE DE FARIA

JOSÉ MATIAS-PEREIRA

JOSÉ ROBERTO FERREIRA GUERRA

JOSÉ RODOLFO TENÓRIO LIMA

JOSÉ VITOR PALHARES DOS SANTOS

JOSEANE DE QUEIROZ VIEIRA

JOSEANE QUEIROZ VIEIRA

JOSIANE SILVA DE OLIVEIRA

JOYSI MORAES

JUAREZ AZEVEDO DE PAIVA

JULIANA OLIVEIRA ANDRADE

KELLEN DA SILVA COELHO

KÊNIA MUNARETTI FROZZA

KÉSIA APARECIDA TEIXEIRA SILVA

LAUISA BARBOSA PINTO

LAURA DA VEIGA

LAURO SANTOS PINHEIRO

LEANDER LUIZ KLEIN

LEANDRO DOMINGUES DOS SANTOS

LHAYENNY RHISTAYNNE LIRA DE

OLIVEIRA

LILIAM DEISY GHIZONI

LÍLIAN BAMBIRRA DE ASSIS

LILIANE DE OLIVEIRA GUIMARÃES

LILLIAN BASTIAN

LINDOMAR PINTO DA SILVA

LUCAS CANESTRI DE OLIVEIRA

LÚCIA REJANE DA ROSA GAMA

MADRUGA

LUCIANA FRANCISCO DE ABREU

RONCONI

LUCIANA MADEIRA BARROS COIMBRA

LUCIANO D'ASCENZI

LUCIANO MENDES

LUCIANO MENEZES BEZERRA SAMPAIO

LUCIANO ROSSONI

LUCIENE LOPES BAPTISTA

LUCÍLIA REGINA DE SOUZA MACHADO

LUCIMAR FERRAZ DE ANDRADE

MACEDO

LUÍS ANDRÉ ARAGÃO FROTA

LUIS CARLOS ZUCATTO

LUÍS FERNANDO SILVA ANDRADE
LUIS PAULO BRESCIANI

LUIS ROQUE KLERING

LUIZ ALBERTO MARIZ

LUIZ FERNANDO DE CARVALHO

LUIZ FERNANDO MACEDO BESSA

LUIZ MARCELO ANTONIALLI

LUMA LOUISE SOUSA LOPES

MAÍRA COELHO BONILHA

MARCELLE COLARES OLIVEIRA

MARCELO CONTERATO

MARCELO HENRIQUE DE ARAUJO

MARCELO JOSÉ BRAGA

MARCELO MARCHESINI DA COSTA

MÁRCIA DA SILVA COSTA

MÁRCIA MICHELLE CARNEIRO DA

SILVA

MÁRCIA REGINA FERREIRA

MÁRCIO ANDRÉ LEAL BAUER

MARCOS GILSON GOMES FEITOSA

MARCOS ROBERTO KUHL

MARGARIDA MARIA SILVA DOS

SANTOS

MARIA CECILIA BEZERRA TAVARES

MALAIA

MARIA CECÍLIA GOMES PEREIRA

MARIA CECÍLIA TEIXEIRA REIS

MARIA DE FATIMA MARTINS

MARIA DO CARMO BRANT DE

CARVALHO

MARIA DO CARMO MEIRELLES TOLEDO

CRUZ

MARIA GRACINDA CARVALHO

TEIXEIRA

MARIA IOLANDA SACHUK

MARIA JOSÉ BARBOSA DE SOUZA

MARIA LAÍS DOS SANTOS LEITE LEAL

MARIA LUISA MENDES TEIXEIRA

MARIA MAGDALENA VILA URIBE

MARIA NAIULA MONTEIRO PESSOA

MARIA RAQUEL CAIXETA GANDOLFI

MARIA SUZANA MOURA

MARIANA LUÍSA DA COSTA LAGE

MARIANA SIMÕES FERRAZ DO

AMARAL FREGONESI

MARINA DANTAS DE FIGUEIREDO

MARINALVA DE JESUS OLIVEIRA

MÁRIO VINÍCIUS CLAUSSEN SPINELLI

MARLETE BEATRIZ MAÇANEIRO

MARLUSE MARTINS DE MATOS

MAURÍCIO CUSTÓDIO SERAFIM

MAURÍCIO SARDÁ FARIA

MAURO GUILHERME MAIDANA

CAPELARI

MAURO SILVA RUIZ 
MICHELLE FIRMINO CELESTINO

MOREIRA

MIGUEL ANGEL VERDINELLI

MIGUEL RIVERA PERES JR.

MILTON CARLOS FARINA

MILTON CORDEIRO FARIAS FILHO

MILTON LUIZ WITTMANN

MINELLE ENÉAS DA SILVA

NATHÁLIA CARVALHO MOREIRA

NATHÁLIA DE FÁTIMA JOAQUIM

NELSON DA CRUZ MONTEIRO

FERNANDES

NICHOLAS JOSEPH TAVARES DA CRUZ

NILTON DOS SANTOS PORTUGAL

ODEMIR VIEIRA BAÊTA

OSÍRIS LUÍS DA CUNHA FERNANDES

PATRICIA BRANT MOURÃO TEIXEIRA

MENDES

PATRÍCIA DIAS

PATRÍCIA TRINDADE CALDAS

PAULO ARAÚJO PONTES

PAULO DA CRUZ FREIRE DOS SANTOS

PAULO EMÍLIO MATOS MARTINS

PAULO OTOLINI GARRIDO

PAULO RICARDO DA COSTA REIS

PAULO ROBERTO ARVATE

PEDRO DOS SANTOS PORTUGAL

JÚNIOR

PEDRO GUIDO GUIMARÃES

PEDRO HENRIQUE DE GOIS

PEDRO JAIME DE COELHO JÚNIOR

PETERSON ELIZANDRO GANDOLFI

POLLIANA DE LUNA NUNES BARRETO

PRISCILA REZENDE DA COSTA

RAFAEL CUBA MANCEBO

RAFAEL DIOGO PEREIRA

RAFAEL KRUTER FLORES

RAFAELA COSTA CRUZ BARBIERI

RAQUEL FINAMOR CARDOSO

RAQUEL MENEZES BEZERRA SAMPAIO

RAQUEL REJANE BONATO NEGRELLE

REBECA DA ROCHA GRANGEIRO

REYNALDO MAIA MUNIZ

RICARDO ALMEIDA ABDALA

RICARDO BRESLER

RICARDO CARNEIRO

RICARDO CORRÊA GOMES

ROBERTO PATRUS PENA

ROBERTO RODRIGUES RAMOS

RODRIGO CASSIMIRO DE FREITAS

RODRIGO KUYUMJIAN

RODRIGO SILVA DINIZ LEROY

RONAN PEREIRA CAPOBIANGO

ROSA MARIA CASTILHOS FERNANDES
ROSA TERESA MOREIRA MACHADO

ROSALIA ALDRACI BARBOSA

LAVARDA

RUI MESQUITA CORDEIRO

SAIONARA BONFIM SANTOS

SANDRA MARIA DOS SANTOS

SANDRA R. H. MARIANO

SANDRO APARECIDO GONÇALVES

SANDRO CABRAL

SANDRO PEREIRA SILVA

SERGIO BULGACOV

SÉRGIO CARVALHO BENÍCIO DE MELLO

SÉRGIO ROBERT DE SANT'ANNA

SÉRGIO SCHNEIDER

SIDINEI ROCHA DE OLIVEIRA

SIEGLINDE KINDL DA CUNHA

SILVIA GATTAI

SILVIA HELENA PASSARELLI

SILVIA MARIA BAHIA MARTINS

SIMÃO PEREIRA DA SILVA

SIMONE DE LIRA ALMEIDA

SIRLEI GLASENAPP

SOLANGE REGINA MARIN

SÔNIA MARIA DA SILVA GOMES

SÔNIA MARIA GUEDES GONDIM

SUELINE SILVA SOUZA

SUELY SALGUEIRO CHACON

SUYLAN DE ALMEIDA MIDLEJ E SILVA

SYLVIA CONSTANT VERGARA

TÁBATA CHRISTIE FREITAS MOREIRA

TAMARA ILINSKY CRANTSCHANINOV

TATIANA RIBEIRO VELLOSO

TELMA HOYLER

TELMA REGINA DA COSTA GUIMARÃES

BARBOSA

TEMÍSTOCLES MURILO OLIVEIRA

JUNIOR

THAÍS BARBOSA FERREIRA

THAISA ANDRADE DE FREITAS

THIAGO DE MELO TEIXEIRA DA COSTA

THIAGO TEIXEIRA SANT'ANA E

CASTRO

TOBIAS COUTINHO PARENTE

VAGNER ALVES ARANTES

VALCEMIRO NOSSA

VALDERÍ DE CASTRO ALCÂNTARA

VALDIR ROQUE DALLABRIDA

VALÉRIA MARIA MARTINS JUDICE

VANESSA BRULON SOARES

VERÔNICA SALGUEIRO DO

NASCIMENTO

VERONIKA PAULICS

VICENTE DA ROCHA SOARES FERREIRA

VIRGÍLIO CÉZAR DA SILVA E OLIVEIRA 
VIRGÍNIA DONIZETE DE CARVALHO VITOR FRANCISCO SCHUCH JÚNIOR WALERY COSTA DOS REIS

WALMER FARONI

WELLINGTON TAVARES

WENDEL ALEX CASTRO SILVA
WILSON APARECIDO COSTA DE AMORIM

YANA MOURA SOUSA

YASMINE MANSUR

YUNA FONTOURA

ZILMA BORGES DE SOUZA

Lista de pesquisadores classificados como entrantes na Rede de Pesquisadores de Gestão Social (RPGS), durante o período de 2005 a 2015.

ADLLER MOREIRA CHAVES

AIRTON CARLOS PATZLAFF

ALESSANDRA BANDEIRA AZEVEDO

ALEX DOS SANTOS MACEDO

ALEXANDRE SETTE ABRANTES

FIORAVANTE

ANA LUCIA CASTILHO DA MOTA

ANA PAULA DENTE VITELLI MORGADO

ANA PAULA FERREIRA ALVES

ANDERSON DIEGO FARIAS DA SILVA

ANGELINA MARIA DE OLIVEIRA

LICORIO

ANGELINE COIMBRA T M ALVES

ANTONIO LUIZ ROCHA DACORSO

ARIELA KARANI DA SILVA

AUGUSTO DE OLIVEIRA TAVARES

BRENDOW OLIVEIRA FRAGA

BRUNA RODRIGUES DE FREITAS

BRUNO DE JESUS LOPES

BRUNO HENRIQUE AGUIAR

BRUNO LUAN DANTAS CARDOSO

BRYAN SILVA ANDRADE

CAMILA SANT'ANNA GOMIDE

CARLA CRISTINA DA SILVA

CARLOS NAZARENO FERREIRA BORGES

CARLOS ROSANO-PEÑA

CASSIA ENGRES MOCELIN

CECILIA ALVES DA SILVA ANTERO

CLAUDEMIR FRANCISCO ALVES

CLÁUDIA MAGALHÃES DROUVOT

CLEUSIMAR CARDOSO ALVES

ALMEIDA

CRISTIANE SILVA PENTEADO

BERTOLINO

CRISTINA CAETANO DE AGUIAR

DAIANE BATISTA DE JESUS

DAIANE MÜLLING NEUTZLING

DAN BARON

DANIEL NETO FRANCISCO

DANIELA ALTHOFF PHILIPPI

DANIELA ARAÚJO DOS ANJOS

DANIELA BORGES LIMA DE SOUZA
DANIELLE VALENTE DUARTE

DAYANA CURY ROLIM

DEISE DANIELLE DIAS NEVES PIAU

DENISE ROSSATO QUATRIN

DERICK DOS SANTOS TINÔCO

EDIMILSON EDUARDO DA SILVA

ELISABETE CORCETTI

EMANUEL CAMILO DE OLIVEIRA

MARRA

ÉRICA ALINE FERREIRA SILVA

EVA REGINA DO NASCIMENTO LOPES

FABIANA CAVA

FABRÍCIA JÚNIA DE OLIVEIRA

MARTINS

FERNANDO ANTÔNIO FRANÇA SETTE

PINHEIRO JÚNIOR

FLANDER ALMEIDA CALIXTO

FRANCISCO SERGIO DE ALMEIDA NETO

GABRIELA PELEGRINI TISCOSKI

GARDÊNIA DA SILVA ABBAD

GILBERTO DA MATA

GILNEY BARROS

GISLAINE APARECIDA SANTANA

SEDIYAMA

GRAZIELLE SILVA SUCUPIRA

GUSTAVO LEONARDO SIMÃO

HELOISA HELENA MESQUITA MACIEL

HUBERT DROUVOT

IVAN DA SILVA MELO

JAMILE SOUZA SOUZA

JEFFERSON LINDBERGHT DE SOUSA

JÉSSICA NATÁLIA SILVA

JOICE DE SOUZA FREITAS SILVA

JOSÉ DE ARIMATÉIA DIAS VALADÃO

JOSÉ DE JESUS MARQUES DE SOUSA

JOSÉ EMANUEL MEDEIROS

MARINHEIRO

JOSE LINDENBERG JULIÃO XAVIER

FILHO

JOSE ORCELIO NASCIMENTO

JOSÉ RICARDO VITÓRIA

JOSEP PONT VIDAL 
JOSIEL LOPES VALADARES

JUAN LEANDRO MUNT

JÚLIA CARVALHO MACHADO

JULIANA KERN

JULIANA MORO BUENO

JULIANA RABELO PEREIRA

KERLA FABIANA DIAS CABRAL

LAÍS BATISTA PEREIRA

LARISSA TEIXEIRA DA CUNHA

LAURO EMÍLIO GONZALEZ FARIAS

LAYON CARLOS CEZAR

LEONARDO CARVALHO LADEIRA

LIANNA KARLA VERAS E SOUZA

LISANDRO PEZZI SCHMIDT

LITIANE BARBOSA MACEDO

LÍVIA DE PAULA BRAGA

LORENA SILVA DE JESUS

LUCAS PAZOLINI DIAS RODRIGUES

LUCAS TECH DOS SANTOS

LUIS MIGUEL LUZIO DOS SANTOS

LUNA MARQUEZ FEROLLA

MARCEL IVAN DOS SANTOS

MARCELO BISPO

MARCELO DE OLIVEIRA VIDAL

MARCELO MOURA

MÁRCIA GOMES DE SOUSA

MARCUS VINICIUS MOREIRA ZITTEI

MARIA AMÁLIA DA COSTA BAIRRAL

MARIA BETHÂNIA BATISTA

MARIA DE LOURDES SOUZA OLIVEIRA

MARIA JOSÉ TONELLI

MARIA JÚLIA CLEMENTE VECCHI

MARÍLIA DELLA LUCIA GOMES

MARJORIE ANGÉLICA SABIONI

FERREIRA

MELQUIADES AUGUSTO PIMENTA

NETO

MIGUEL PACÍFICO FILHO

MILANYA RIBEIRO DA SILVA

MÍRIAN OLIVEIRA

MONIQUE DA SILVA SANTANA
MYRIAM MARTA MELLO

NATHÁLIA CÂNDIDO DA SILVA

NICOLAU REINHARD

OSMAR SIENA

PAULA BELGO MORAES

PAULO HENRIQUE MONTAGNANA

VICENTE LEME

PEDRO HENRIQUE MACHADO PEREIRA

PRISCILA MARIA GREGOLIN PATZLAFF

RAFAEL JUNIOR DOS SANTOS

FIGUEIREDO SALGADO

RAFAELLA CRISTINA CAMPOS

RAONI DE OLIVEIRA INÁCIO

RAQUEL OLIVEIRA WILDHAGEN

REINALDO ANTÔNIO BASTOS FILHO

RENATO ORSATO

RODRIGO BURKOWSKI

ROSSI HENRIQUE SOARES CHAVES

RUBENS DE ARAUJO AMARO

SABRINA OLIMPIO CALDAS DE CASTRO

SAMUEL RODRIGO DA SILVA

SIMONE ALVES PACHECO DE CAMPOS

SIMONE RUCHDI BARAKAT

SINDELY CHAHIM DE AVELLAR

ALCHORNE

TAIRINE MONIELLI PONTAROLO

TALITA ROSOLEN

TATIANA VILELA CARVALHO

THAIS OLIVEIRA DUQUE

THELMA PONTES BORGES

THIAGO REIS XAVIER

THOMAZ ANDERSON BARBOSA SILVA

VANDER LUIZ AGUIAR

VANESSA SILVEIRA PEREIRA SIMON

VÂNIA MARIA JORGE NASSIF

VICENTE LIMA CRISÓSTOMO

VIDIGAL FERNANDES MARTINS

VINICIUS SOUZA MOREIRA

VIVIAN DUARTE COUTO FERNANDES

VIVIANE MARIA HEBERLE

WELLINGTON ALVIM DA CUNHA

Lista de pesquisadores classificados como retirantes na Rede de Pesquisadores de Gestão Social (RPGS), durante o período de 2005 a 2015.

ADEMAR DUTRA

ADEMÁRIO DE JESUS

ADILSON DE LIMA TAVARES

ADRIANA MARIA PROCÓPIO DE

ARAÚJO

ADRIANA MARQUES ROSSETTO
ADRIANA ROSELI WÜNSCH

TAKAHASHI

ADRIANA SILVA OLIVEIRA ARRUDA

ADRIANA TEIXEIRA BASTOS

ADRIANA TENÓRIO CORDEIRO

ADRIANE VIEIRA 
ADRIANO PROVEZANO GOMES

AGNALDO KEITI HIGUCHI

AIDA MARIA LOVISON

ALBA DE OLIVEIRA BARBOSA

ALESSANDRA MELLO DA COSTA

ALESSANDRO RIBEIRO DE CARVALHO

CASALECCHI

ALEXANDRE ARAÚJO CAVALCANTE

SOARES

ALEXANDRE CESTARI DE BRITO

ALEXANDRE FARIA

ALEXANDRE GOMES GALINDO

ALEXANDRE REIS ROSA

ALFREDO RODRIGUES LEITE DA SILVA

ALINE CRAIDE

ALINE FERNANDES GUIMARÃES

ALINE RODRIGUES FERNANDES

ALLENE CARVALHO LAGE

ALPENIANO SILVA FILHO

AMANDA CRISTINA MEDEIROS

AMANDA MAGRINELI DOS REIS

AMAURY JOSÉ REZENDE

AMÍLCAR BAIARDI

AMON NARCISO DE BARROS

ANA AKEMI IKEDA

ANA BEATRIZ NUNES DA SILVA

ANA CAROLINA ARAÚJO DE ALMEIDA

ANA CLARA RODRIGUES BARROS

ANA FLÁVIA TEIXEIRA

ANA LÚCIA SUAREZ MACIEL

ANA MÁRCIA BATISTA ALMEIDA

ANA MARIA DE ARAUJO ANANIAS

ANA MARIA NAVAES DA SILVA

ANA PATRÍCIA RODRIGUES LEITE

ANA PAULA DANTAS FERREIRA DA

ROCHA

ANDERSON DA SILVA RODRIGUES

ANDERSON FELISBERTO DIAS

ANDERSON GIOVANI DA SILVA

ANDERSON SASAKI VASQUES

PACHECO

ANDRÉ ARISTÓTELES DA ROCHA

MUNIZ

ANDRÉ FERREIRA

ANDRÉ RODRIGUES DOS SANTOS

ANDRÉ VILLAS-BÔAS

ANDRÉA CARDOSO VENTURA

ANDRÉIA APARECIDA ALBINO

ANDREIA CRISTINA RESENDE DE

ALMEIDA

ANELISE GRACIELE RAMBO

ÂNGELA GORDILHO BARBOSA

ÂNGELA LIMA CALOU

ANGELA MARIA MAURER
ANNE CAROLINE MOURA GUIMARÃES

CANÇADO

ANTỐNIA ANASTACIA PACHECO DE

OLIVEIRA

ANTONIA EGÍDIA DE SOUZA

ANTÔNIO CARLOS BRUNOZI JÚNIOR

ANTÔNIO CARLOS DOS SANTOS

ANTONIO CARLOS MAGALHÃES DA

SILVA

ANTONIO CARVALHO NETO

ANTONIO DOMINGOS PADULA

ANTONIO ED SOUZA SANTANA

ANTONIO ÉDIO PINHEIRO CALLOU

ANTONIO GIL DA COSTA JUNIOR

ANTÔNIO JOÃO HOCAYEN-DA-SILVA

ANTONIO LUCAS CORDEIRO FEITOSA

ANTÔNIO OLIVEIRA DE CARVALHO

ARACÉLI CRISTINA DE SOUSA

FERREIRA

ARI DE SOUZA SOARES

ARISTON AZEVÊDO MENDES

ARTUR CAMPOS CHEIB

ATAUALPA LUIZ DE OLIVEIRA

AUGUSTO OLIVEIRA TAVARES

BÁRBARA COELHO NEVES

BEATRIZ BITTENCOURT ANDRADE

BILL NUNES PEREIRA

BRUNNA CARVALHO ALMEIDA

BRUNO CALS DE OLIVEIRA

BRUNO CÉSAR SANTOS DE

ALCÂNTARA

BRUNO MILANEZ

CAMILA FURLAN DA COSTA

CAMILA MENDONÇA CARISIO

CARLA PATRICIA DA SILVA SOUZA

CARLA REGINA PASA GÓMEZ

CARLOS ALBERTO BARBOSA DE SOUZA

CARLOS ALBERTO CIOCE SAMPAIO

CARLOS ALBERTO VARGAS ROSSI

CARLOS CAVALCANTE

CARLOS MACIEL STIEG

CARLOS ROBERTO DOMINGUES

CAROLINA LESCURA DE CARVALHO

CASTRO

CAROLINA MACHADO SARAIVA DE

ALBUQUERQUE MARANHÃO

CAROLINA RIENTE DE ANDRADE

CÁSSIA HELENA PEREIRA LIMA

CÁSSIO AFONSO MEDEIROS LANA

CATARINA CECILIA ODELIUS

CELSO FUNCIA LEMME

CEZAR AUGUSTO MIRANDA GUEDES

CHRISTIAN DÁRLIO BRITO ARRUDA

CHRISTIANE LUCI BEZERRA ALVES 
CIBELE FRANZESE

CÍNTIA BECKER

CLAIRE GOMES DOS SANTOS

CLARICE PEREIRA DE PAIVA RIBEIRO

CLARÍCIO DOS SANTOS FILHO

CLARISSA ALMEIDA DE SANTANA

CLÁUDIA FERREIRA CRUZ

CLÁUDIA MOREIRA BORGES

CLAUDIANI WAIANDT

CLAUDINETE DE FÁTIMA SILVA

OLIVEIRA SANTOS

CLEBER CARVALHO DE CASTRO

CLEITON FABIANO KLECHEN

CLÉRIA DONIZETE DA SILVA

LOURENÇO

CLEVERSON RENAN DA CUNHA

CLÓVIS L. MACHADO-DA-SILVA

CRISTIANE GANDOLFI

CRISTIANE SIMÕES NETTO COSTA

CRISTINA AMÉLIA PEREIRA DE

CARVALHO

CRISTINA MARIA DACACH FERNANDEZ

MARCHI

CYBELE AMADO DE OLIVEIRA

DAGMAR SILVA PINTO DE CASTRO

DANIEL GUSTAVO FLEIG

DANIEL LANNA PEIXOTO

DANIELA ABRANTES FERREIRA SERPA

DANIELA MEIRELLES ANDRADE

DANIELA VIEGAS

DANIELLE DE ARAÚJO BISPO

DANIELLE MARTINS DUARTE COSTA

DANIELLE RAMOS DE MIRANDA

PEREIRA

DANILO DE OLIVEIRA SAMPAIO

DANTE PINHEIRO MARTINELLI

DÉBORA NACIF DE CARVALHO

DEBORAH MORAES ZOUAIN

DEBORAH RIGGENBACH

DENILSON BEZERRA MARQUES

DENISE CARNEIRO DOS REIS

BERNARDO

DENISE DEL PRA NETTO MACHADO

DENISE FRANCA BARROS

DENISE RIBEIRO

DENISE TERRA

DERANOR GOMES DE OLIVEIRA

DIANA COSTA DE CASTRO

DIEGO BONALDO COELHO

DJALMA FREIRE BORGES

DORA MARIA ORTH

DOUGLAS VINÍCIUS VAZ MARTINS

DUARTE DE SOUZA ROSA FILHO

EDI AUGUSTO BENINI
EDINELZA MACEDO RIBEIRO

EDUARDO ANDRÉ TEIXEIRA AYROSA

EDUARDO DAVEL

EDUARDO ERNESTO FILIPPI

EDUARDO GOMOR DOS SANTOS

EDWALDO SÉRGIO DOS ANJOS JÚNIOR

ELAINE DI DIEGO ANTUNES

ELAINE FERREIRA

ELCIO GUSTAVO BENINI

ELDA CILENE FONSECA COSTA SANTOS

ELIANE BARBOSA DA CONCEIÇÃO

ELIANE SILVA CARA

ELIAS RODRIGUES DE OLIVEIRA

ELISA ZWICK

ELISABETE STRADIOTTO SIQUEIRA

ELISABETH LISBOA PINTO

ELISÂNGELA ABREU NATIVIDADE

ELIZABETH MATOS RIBEIRO

ELOISE HELENA DO LIVRAMENTO

DELLAGNELO

ELOY ANTONIO FENKER

ELVIRA CRUVINEL FERREIRA

VENTURA

EMILSON GUSMÃO PIAU SANTANA

ENISE BARTH TEIXEIRA

ÉRICA BERANGER SILVA SOARES

ERIKA COSTA DA SILVA GAUDEOSO

ERIVELTON GUIZZARDI

ERLAINE BINOTTO

ERNANI DE SOUZA GUIMARÃES JÚNIOR

EUNÁPIO DUTRA DO CARMO

EURIPEDES MAGALHÃES DE OLIVEIRA

EVA MARIA CAMPOS

EVANDRO CAVALCANTE FERREIRA

GOMES

EVANDRO RODRIGUES DE FARIA

EVÂNIO MASCARENHAS PAULO

FÁBIO GUEDES GOMES

FÁBIO VIZEU

FÁTIMA REGINA NEY MATOS

FELIPE CARABETTI GONTIJO

FERNANDA BRUTO DA COSTA CORREIA

FERNANDA FILGUEIRAS SAUERBRONN

FERNANDA GABRIELA BORGER

FERNANDA TARABAL LOPES

FERNANDO CAETANO COSTA

FERNANDO CÉSAR ALMADA SANTOS

FERNANDO DIAS LOPES

FERNANDO PIRES DOS SANTOS

FLÁVIA KELLER ALVES CARVALHO

FLÁVIA LOPES PACHECO

FLÁVIA ZÓBOLI DALMÁCIO

FRANCIELLE DA SILVA

FRANCISCO CÉSAR DE CASTRO NETO 
FRANCISCO DE ASSIS SOARES FRANCISCO GABRIEL HEIDEMANN FRANCISCO GIOVANNI DAVID VIEIRA FRANCISCO JOSÉ DA COSTA FRANCISCO LEITE HOLANDA JÚNIOR FRANCISCO SÁVIO DE OLIVEIRA BARROS

FRANCISCO SILVA

GABRIELA CARVALHO PEREIRA GELSON SILVA JUNQUILHO GILBERTO BRAGA PEREIRA GILDÁSIO SANTANA JÚNIOR GILMARA INÁCIO VIEIRA GLAUCO DA COSTA KNOPP GRACE KELLY MARQUES RODRIGUES GUILHERME AUGUSTO DOIN GUSTAVO HENRIQUE NOGUEIRA DE ANDRADE

GUSTAVO MADEIRO DA SILVA GUSTAVO MARQUES DA COSTA GUSTTAVO CÉSAR OLIVEIRA LIMA HELDER PONTES RÉGIS HELEN DE MONTILLE FERREIRA HENRIQUE CORDEIRO MARTINS HENRIQUE LUIZ CAPRONI NETO HUDSON FERNANDES AMARAL IGOR VINICIUS LIMA VALENTIM ILKA CAMAROTTI INGRID MAZZA MATOS ISABELA VELOSO LOPES VERSIANI ISRAEL FERREIRA JÚNIOR IVETE APARECIDA PATIAS IVETE RODRIGUES IVONNE PAOLA REQUENA GUZMÁN IVY SILVA COSTA JACQUELAINE FLORINDO BORGES JADER CRISTINO DE SOUZA-SILVA JÁDER FAÇANHA CÂMARA JAIME EVALDO FENSTERSEIFER JAIR SAMPAIO SOARES JÚNIOR JAMES ANTHONY FALK JANAÍNA MACHADO SIMÕES JANAINA MACKE JANAÍNA MARIA BUENO JANAINA OTTONELLI JANANN JOSLIN MEDEIROS JANAYNA ARRUDA BARROSO JAQUELINE ROSSATO JEFERSON SIMÕES SANTANA JEOVAN DE CARVALHO FIGUEIREDO JESÚS DOMECH MORÉ JOÃO FELIPE RAMMELT SAUERBRONN JOÃO GUALBERTO MOREIRA VASCONCELLOS
JOÃO MARCELO CRUBELLATE JOEL DE LIMA PEREIRA CASTRO JUNIOR

JOHANNES KÜCHLER

JOMÁRIA MATA DE LIMA ALLOUFA

JONATHAN FELIX RIBEIRO LOPES

JOSÉ AMÉRICO MARTELLI TRISTÃO

JOSÉ ANTONIO PUPPIM DE OLIVEIRA

JOSÉ ANTONIO VALLE ANTUNES

JÚNIOR

JOSÉ CARLOS BARBIERI

JOSÉ CARLOS SALES DOS SANTOS

JOSÉ CARLOS VAZ

JOSE COELHO DE ANDRADE ALBINO

JOSÉ ELMAR FEGER

JOSÉ FRANCISCO SALM

JOSÉ LUIS FELICIO CARVALHO

JOSÉ MILTON DE SOUSA FILHO

JOSÉ OSVALDO DE SORDI

JOSE OTAVIO MAGNO PIRES

JOSE PAULO FAGUNDES

JOSÉ RICARDO MAIA DE SIQUEIRA

JOSÉ ROBERTO DE OLIVEIRA

JOSÉ ROBERTO RIBAS

JOSELINA DA SILVA

JOYCE DE SOUZA CUNHA MELO

JOYSINETT MORAES DA SILVA

JUDITH ZUQUIM

JÚLIA FURLANETTO GRAEFF

JULIA RODRIGUES NOBRE DE OLIVEIRA

JULIANA CRISTINA TEIXEIRA

JÚLIO ARAÚJO CARNEIRO DA CUNHA

JULIO CANDIDO DE MEIRELLES JUNIOR

JUSTINA TELLECHEA

KARIN VIEIRA DA SILVA

KARLA MARIA DAMIANO TEIXEIRA

KÁTIA SANTOS DE MORAIS

KECYA NAYANE LUCENA BRASIL

KELY CÉSAR MARTINS DE PAIVA

LADISLAU DOWBOR

LAIIS ATANAKA DENÚBILA

LARA PEREIRA MONTEIRO

LARISSA DE JESUS MARTINS

LAURA ANGÉLICA MOREIRA SILVA

LAURA CALIXTO

LAYSCE ROCHA DE MOURA

LEANDRO COSTA SCHMITZ

LEANE NUNES

LEONARDO ENSSLIN

LEONARDO MASCARENHAS

LEONARDO VASCONCELOS CAVALIER

DARBILLY

LEONEL GÓIS LIMA OLIVEIRA

LETÍCIA DIAS FANTINEL 
LIDIA MICAELA SEGRE

LILIAN BARROS MOREIRA

LILIAN SOARES OUTTES WANDERLEY

LINO MARTINS DA SILVA

LOURIVAL BATISTA DE OLIVEIRA

JÚNIOR

LUANA DAS GRAÇAS QUEIRÓZ DE

FARIAS

LUANA EMMENDOERFER

LUCAS LOPES DE PINHEIRO

LUCAS MAIA DOS SANTOS

LUCIANA MOURÃO

LUCIANO BARIN CRUZ

LUCIENE APARECIDA DA SILVA

LUCIENE NASCIMENTO DE ALMEIDA

LUCILA MARIA DE SOUZA CAMPOS

LUIZ ALBERTO NASCIMENTO CAMPOS

FILHO

LUIZ ANTÔNIO ABRANTES

LUIZ AUGUSTO BICHARA

LUIZ CARLOS DE SOUZA FARIA

LUIZ CLÁUDIO SOARES

LUIZ GUSTAVO CAMARANO

NAZARETH

LUIZ MANOEL LOPES

LUIZ ROBERTO SANTOS MORAES

MAISA DE SOUZA RIBEIRO

MAÍSA GOMIDE TEIXEIRA

MANCILDO MOREIRA FILHO

MANOLITA CORREIA LIMA

MANUEL MEIRELES

MANUELA DE OLIVEIRA BOTREL

MANUELA RAMOS DA SILVA

MARCEL DE SOUZA SILVA E SANTOS

MARCELA DE MORAES BATISTA

MARCELLO BECKERT ZAPELINI

MARCELO ÁLVARO DA SILVA MACEDO

MARCELO DE REZENDE PINTO

MARCELO GONÇALVES DO AMARAL

MARCELO MILANO FALCÃO VIEIRA

MARCELO MINÁ DIAS

MARCELO RIBEIRO MOURA

MÁRCIA GONÇALVES PIZAIA

MARCIA MARTINS MENDES DE LUCA

MÁRCIA PREZOTTI PALASSI

MÁRCIO CÉSAR FRANCO SANTOS

MÁRCIO REINALDO DE LUCENA

FERREIRA

MARCIO SILVA BORGES

MARCO ANTONIO PINHEIRO DA

SILVEIRA

MARCOS ADLLER DE ALMEIDA

NASCIMENTO

MARCOS AMATUCCI
MARCOS AURÉLIO DORNELAS

MARCOS COHEN

MARCOS DIAS DE OLIVEIRA

MARCOS LUÍS PROCÓPIO

MARCOS LUIZ FILIPPIM

MARCOS MACHADO DE ALMEIDA

MARCOS ROCHA DE AVÓ

MARCUS VINÍCIUS PEINADO GOMES

MARIA ARLETE DUARTE DE ARAÚJO

MARIA CECI ARAUJO MISOCZKY

MARIA DE FÁTIMA BARBOSA GÓES

MARIA DE FÁTIMA SALES DE SOUZA

CAMPOS

MARIA ESTER DE FREITAS

MARIA ESTER MENEGASSO

MARIA EUGÊNIA MONTEIRO

CASTANHEIRA

MARIA GABRIELA MONTEIRO

MARIA LÚCIA POLITANO ÁLVARES

MARIA RAILMA ALVES

MARIA RITA LOUREIRO

MARIA RUTH SIFFERT DINIZ TEIXEIRA

LEITE

MARIA SCARLET DO CARMO

MARIA SUZANA DE SOUZA MOURA

MARIA TERESA FRANCO RIBEIRO

MARIA TERESA STEFANI

MARIA TEREZA SARAIVA DE SOUZA

MARIA VALESCA DAMÁSIO DE

CARVALHO SILVA

MARIALVA TOMIO DREHER

MARIANA BALDI

MARIANA CAVALCANTI FALCÃO

MARIANA EUGÊNIO ALMEIDA

MARIANA LEONESY DA SILVEIRA

BARRETO

MARIANA MAYUMI PEREIRA DE SOUZA

MARIANA PEREIRA CHAVES PIMENTEL

MARIANO YOSHITAKE

MARÍLIA PAULA DOS REIS TEIXEIRA

MARINES LUCIA BOFF

MARINETTE SANTANA FRAGA

MÁRIO SACOMANO NETO

MARLOS PEREIRA DE JESUS

MARLUSA GOSLING

MELISSA SANTOS BAHIA

MELODY DE CAMPOS SOARES PORSSE

MELODY PORSSE

MÉRCYA ROSE DE OLIVEIRA

CARVALHO

MICHELLE QUEIROZ COELHO

MIGUEL DA COSTA ACCIOLY

MIGUEL EDUARDO MORENO AÑEZ

MILKA ALVES CORREIA BARBOSA 
MIRELLA CAETANO DE SOUZA MIRIAN LÚCIA JÁCOME MACHADO MÔNICA ALVES AMORIM MÔNICA CALIL MÔNICA VALESKA VERAS MACHADO MONIQUE APARECIDA DOS SANTOS MORJANE ARMSTRONG SANTOS MURILO BREHNER DE FARIA ALVES MYRNA SUELY DA SILVA LORÊTO NADIR RAQUEL CUNHA FRANÇA NARA FALQUETO CALIMAN NATALI LORDELLO DE OLIVEIRA NATHALIA KOZONOI

NATHALIE PERRET

NELSON LUIZ DOS SANTOS GARCIA NELSON RUSSO DE MORAES NEUBLER NILO RIBEIRO DA CUNHA NICHOLAS CARVALHO DE ALMEIDA COSTA

NICOLAS RENATO SIQUEIRA ARAUJO

NOMASTON RODRIGUES MOTA

NORA BEATRIZ PRESNO AMODEO

OKLINGER MANTOVANELLI JUNIOR OSCAR JOSÉ ROVER

OTÁVIO PRADO

PALLOMA ROSA FERREIRA PAMELA DE MEDEIROS BRANDÃO PATRÍCIA ALMEIDA ASHLEY PAULO CÉSAR DE SOUSA BATISTA PAULO MAURICIO SELIG PAULO THIAGO NUNES BEZERRA DE MELO PEDRO AGUERRE PEDRO DE ALMEIDA COSTA PETER KEVIN SPINK PRISCILA DE GÓES PEREIRA PRISCILA GOMES DE ARAÚJO RAFAEL RODRIGO MUELLER RAIMUNDO EDUARDO SILVEIRA FONTENELE RAMIRO ZINDER DA SILVA RAQUEL DE OLIVEIRA SANTOS LIRA RAQUEL SANTOS SOARES MENEZES RAQUEL VIANA GONDIM REBECA DE MORAES RIBEIRO DE BARCELLOS

REGINALDO SOUZA SANTOS REJANE PREVOT NASCIMENTO RENATA ALVAREZ ROSSI RENATA DE ALMEIDA BICALHO RENATA OVENHAUSEN ALBERNAZ RENATA ROSSI RICARDO CENEVIVA RICARDO CÉSAR ALVES
RICARDO HERMANY

RICARDO PANDOLFI

RICARDO ROBERTO BEHR

RICARDO SAVACINI PANDOLF

RICARDO SÉRGIO GOMES VIEIRA

RICHARD MEDEIROS DE ARAÚJO

RIVANDA MEIRA TEIXEIRA

ROBINSON HENRIQUE SCHOLZ

ROBSON AMÂNCIO

ROBSON ZUCCOLOTTO

ROCÍO CASTRO KUSTNER

RODRIGO BOUSFIELD

RODRIGO DE SOUZA GONÇALVES RODRIGO GAMEIRO GUIMARÃES

RODRIGO MAIA SANTOS

RODRIGO MIRANDA

ROGÉRIO FAÉ

ROGÉRIO HERMIDA QUINTELLA

ROGÉRIO TEIXEIRA MÂSIH

ROGÉRIO ZANON DA SILVEIRA

RONALDO ANDRÉ RODRIGUES DA

SILVA

RONISE SUZUKI DE OLIVEIRA ROSA MARIA FISCHER

ROSANY CORREA

ROSE MARIE MARIE INOJOSA

ROSELY MORAES SAMPAIO

ROSIMERI CARVALHO DA SILVA

ROSSINE CERQUEIRA DA CRUZ

RUBENILDA SODRÉ DOS SANTOS

RUBENS AUGUSTO DE MIRANDA

SAMARA REGINA BERNARDINO

HOFFMANN

SAMUEL CARVALHO DE BENEDICTO

SANDRA BURLE MARX SMITH

SARAH MARIA DA SILVA GONÇALVES

SEBASTIÃO DÉCIO COIMBRA DE SOUZA

SÉRGIO C. BENÍCIO DE MELLO

SÉRGIO LUÍS BOEIRA

SÉRGIO LUIZ DO AMARAL MORETTI

SIBELLY RESCH

SIDNEI VIEIRA MARINHO

SIEGRID GUILLAUMON

SILVANA ANITA WALTER

SILVIA LAURA COSTA CARDOSO

SÍLVIO LUIZ DE PAULA

SILZE ANNE GONÇALVES LINS

SIMONE FONSECA

SIMONE GHISI FEUERSCHÜTTE

SIMONE MARTINS OLIVERO

SOLANGE MARIA DE SOUZA MOURA

SOLANGE NOVIS RIBEIRO

SONIA MARIA FLEURY TEIXEIRA

SUELI MARIA GOULART SILVA 
SUELLEN SCHMIDT ANDRADE

SUELY MARIA RIBEIRO LEAL

SUZANE STREHLAU

SUZZANA ALICE LIMA ALMEIDA

T. DIANA L. VAN ADUARD DE MACEDO-

SOARES

TACILLA DA COSTA E SÁ SIQUEIRA

SANTOS

TACILLA SIQUEIRA SANTOS

TANESCA SANTANA SANTOS

TANIA CASADO

TASOS PAPADIMITRIOU

TATIANA ARAÚJO REIS

THAIIS BERNARDES NOGUEIRA

THAIS SOARES KRONEMBERGER

VALDEMIR APARECIDO PIRES

VANESSA PATERNOSTRO MELO
VANIA DE FÁTIMA BARROS

ESTIVALETE

VERA LÚCIA PEIXOTO MENDES

VERA MARIA RODRIGUES PONTE

VICENTE MACÊDO DE AGUIAR VICTORIA RÉGIA ARRAIS DE PAIVA VIRGÍNIA TALAVEIRA VALENTINI

TRISTÃO

VITOR LÉLIO BRAGA

WALESKA JAMES SOUSA FÉLIX

WALTER DE OLIVEIRA PINTO JÚNIOR

WALTER LEE NESS JUNIOR

WAYNE THOMAS ENDERS

WILLIAM ANTONIO BORGES

WILLIAM AUGUSTO PEREIRA

WILLIAM DOS SANTOS MELO

WOLNEY AFONSO PEREIRA

Lista de pesquisadores classificados como one-timers na Rede de Pesquisadores de Gestão Social (RPGS), durante o período de 2005 a 2015.

ADALBERTO BULHÕES

ADALBERTO CARDOSO

ADARLETTE NEIRA

ADEMIR VICENTE DA SILVA

ADILSON ALMEIDA DOS SANTOS

ADOLFO HENRIQUE COUTINHO E SILVA

ADOLFO SILVA

ADRIAN ZACARIAS SILVA DE OLIVEIRA

ADRIANA ALVES SANTANA

ADRIANA CARLA AVELINO MAZZA

ADRIANA CÉLIA DA SILVA BICALHO

ADRIANA DE FARIA E SOUSA

ADRIANA DE SOUZA NUNES

ADRIANA DIAS

ADRIANA FONSECA VELOSO

ADRIANA MAROTTI DE MELLO

ADRIANA MICHELETTO BRANDÃO

ADRIANA PROENÇA

ADRIANA REGINA C. ESPÍNDOLA

ADRIANA RIBEIRO BRANGION

ADRIANA ROFMAN

ADRIANA SILVA ARAÚJO

ADRIANA VICTORIA GARIBALDI DE

HILAL

ADRIANA VIEGAS ARAÚJO

ADRIANA VINHOLI RAMPAZO

ADRIANO BORGES COSTA

ADRIANO DA SILVA COSTA

ADRIANO FIRMINO VALDEVINO

ADRIANO LAGO

ADRIANO PRYSTHON DA SILVA

ADRIELLE VICTORIA SOARES
AFEF BENESSAIEH

AFRÂNIO CARVALHO AGUIAR

AGATHA CRUZ DE PAULA

AGATHA JUSTEN

AGHATA GONSALVES

AGNALDO BATISTA

AGNALDO GARCIA

AGOSTINHO LOPES VENÂNCIO

AHIRAM BRUNNI CARTAXO DE CASTRO

AIGLINE DE MENEZES PAES VERVLOET

AÍLA MARIA ALVES CORDEIRO ARRAIS

AIRES JOSÉ ROVER

AISSATU ZENANI LOPES SILA

AKARIÊ JULIÃO SANTOS

ALAIN CHARLES MARTINET

ALBENE DICÍULA PIAU VASCONCELOS

ALBERT BARTOLOMEU DE SOUSA

ROSA

ALBERTO PASCHOAL TREZ

ALBINO ALVES SIMIONE

ALCEU SOUZA

ALCIDES FERNANDO GUSSI

ALCIELIS DE PAULA NETO

ALDAIZA SPOSATI

ALDO LEONARDO CUNHA CALLADO

ALECXANDRE PEPE REIS

ALEJANDRA ASTRID LEÓN CEDEÑO

ALEJANDRA PEÑA GARCÍA

ALEKSANDAR DUNDJEROVIC

ALESSANDRA CABRAL NOGUEIRA

ALESSANDRA CARLA CEOLIN

ALESSANDRA LIVIA LIMA DOS SANTOS 
ALESSANDRA MAGRINI

ALESSANDRA MARQUES DA SILVA

ALESSANDRA PAULINA FERREIRA

ALESSANDRO FERREIRA ALVES

ALESSANDRO GOMES ENOQUE

ALESSANDRO GUSTAVO SOUZA

ARRUDA

ALETÉIA DE MOURA CARPES

ALEX BRETAS VASCONCELOS

ALEX BRUNO FERREIRA MARQUES DO

NASCIMENTO

ALEX CONCEIÇÃO SANTOS

ALEX FERNANDES MAGALHÃES

ALEX FERREIRA DE FREITAS

ALEX VASCONCELOS

ALEXANDRA DOS SANTOS REIS

ALEXANDRA QUADRO SIQUEIRA

ALEXANDRE ARAÚJO COSTA

ALEXANDRE BARRAGAT

ALEXANDRE BARRETO DE SOUZA

ALEXANDRE BEVILACQUA LEONETI

ALEXANDRE COIMBRA RIBEIRO

ALEXANDRE COSTA QUINTANA

ALEXANDRE DE ALMEIDA FARIA

ALEXANDRE DE FREITAS CARNEIRO

ALEXANDRE DE MELO ABICHT

ALEXANDRE GARCIA ALMEIDA

ALEXANDRE GORI MAIA

ALEXANDRE MADURO-ABREU

ALEXANDRE MARCELO GUEDES

ALEXANDRE MEIRA DE VASCONCELOS

ALEXANDRE MENDES NICOLINI

ALEXANDRE QUEIROZ GUIMARÃES

ALEXANDRE SANCHES GARCIA

ALEXANDRE SANTOS

ALEXANDRE ZOURABICHVILI

ALEXIA HOPPE

ALEXSANDER DAUZELEY DA SILVA

ALEXSANDRA NASCIMENTO DA SILVA

ALFREDO MACIEL DA SILVEIRA

ALFREDO SILVA

ALICIA FERREIRA GONÇALVES

ALINE BARBOZA DE LIMA

ALINE BENSO

ALINE FARIAS

ALINE GONÇALVES PEREIRA

ALINE LOUISE KERCH

ALINE MARON SETENTA

ALINE MARQUES FERNANDES

ALINE TEIXEIRA VIEIRA ALVES

ÁLISON KLENER PEREIRA RIBEIRO

ALISSON EDUARDO MAEHLER

ALISSON PENNA DE SOUZA

ALLANA KELLY NASCIMENTO NUNES
ALTAIR CAMARGO FILHO

ALTAMIR DA SILVA SOUZA

ALUÍZIO ANTÔNIO DE BARROS

ALVANY MARIA DOS SANTOS

SANTIAGO

ÁLVARO BARBOSA MENESES

DOMINGOS

ÁLVARO GUILLERMO ROJAS LEZANA

ÁLVARO MIRANDA LEITE RIBEIRO

ÁLVARO PEDRO CARVALHO

MAGALHÃES

ÁLVARO SÁENZ ANDRADE

ALVINO SANCHES FILHO

ALZENIR MORAIS FERREIRA

ALZIMA KUSHIMA

AMALIA MARIA GOLDBERG GODOY

AMANDA FARIAS CAMPELO

AMANDA LEANDRO CONCEIÇÃO

LICERIO

AMANDA LIRA BRANDAO

AMANDA MARIANA FRANÇA

AMARILIS LUCIA CASTELI FIGUEIREDO

GALLARDO

AMAURY ALAN MARTINS DE SOUZA

JUNIOR

AMÉLIA CORRÊA PASSOS

AMELIA SILVEIRA

ANA AMÉLIA MAGALHÃES

ANA ANGÉLICA BEZERRA DE MELO

ROCHA

ANA ARAÚJO DE VASCONCELOS

ANA AUGUSTA ALMEIDA DE SOUZA

ANA AUGUSTA FERREIRA DE FREITAS

ANA BEATRIZ SIMON FACTUM

ANA CARLA FERREIRA DE OLIVEIRA

ANA CARLA JUNQUEIRA MEIRELLES

ROBERTO

ANA CAROLINA CARVALHO BARRETO

ANA CAROLINA FERREIRA SERAFIM

ANA CAROLINA FONSECA

ANA CAROLINA KRUTA

ANA CAROLINA MENEZES DA GLORIA

ANA CAROLINA NUNES CARVAHO

ANA CAROLINA PEREIRA ZOGHBI

ANA CAROLINA PIMENTEL DUARTE DA

FONSECA

ANA CAROLINA UTSCH CORRÊA

ANA CAROLINE MENEZES DA GLÓRIA

ANA CAROLINE RODRIGUES DIAS

ANA CLARA APARECIDA ALVES DE

SOUZA

ANA CLÁUDIA A. GONÇALVES

ANA CLAUDIA BANSI 
ANA CLAUDIA CALDAS MENDONÇA SEMEDO

ANA CLÁUDIA FERNANDES TERENCE

ANA CLÁUDIA GOMES

ANA CRISTINA DE FARIA

ANA CRISTINA VALENTE BORGE

ANA CRISTNA LIMONGI FRANÇA

ANA FLÁVIA BADUE

ANA FLÁVIA CARVALHO CARDOSO

ANA FLAVIA DE LIMA

ANA FLÁVIA DE MORAES

ANA GABRIELA CALDEIRA DIAS

ANA GEORGINA PEIXOTO ROCHA

ANA GOMES MALLMANN

ANA IZABEL CARDOSO DE OLIVEIRA

ANA JÚLIA ESTEVES DE

VASCONCELLOS

ANA KARINA MARQUES DA CUNHA

LESSA

ANA KAROLINA PEREIRA GOMES

ANA LEONOR PIANCÓ DE BRITO

ANA LÍGIA PIRES

ANA LÍVIA DE SOUZA COIMBRA

ANA LOUISE DE CARVALHO FIÚZA

ANA LÚCIA ARAGÃO

ANA LÚCIA FREZZATTI SANTIAGO

ANA LUCIA MACIEL

ANA LUCIA MIRANDA LOPES

ANA LÚCIA ROTH

ANA LUISA KONDO

ANA LUISA LORENZON

ANA LUIZA ROCHA DO VALLE

ANA LUIZA SZUCHMACHER VERISSIMO

LOPES

ANA LUIZA VIOLATO ESPADA

ANA MARCIA FORNAZIERO RAMOS

ANA MARIA D'ÁVILA LOPES

ANA MARIA LIMA DAOU

ANA MERCEDES SARRIA ICAZA

ANA PAULA BORGES GONÇALVES

ANA PAULA DEBASTIANI VASCO

ANA PAULA FERREIRA DA SILVA

ANA PAULA FERREIRA DOS SANTOS

ANA PAULA FRACALANZA

ANA PAULA MAGALHÃES MACIEL

ANA PAULA NERY ROSADO

ANA PAULA PERLIN

ANA PAULA PRADO GARCIA

ANA ROSA CAMILLO AGUIAR

ANA ROSA DE SOUSA

ANA ROSA GOUVEIA SOBRAL DA

CÂMARA

ANA SÍLVIA PUPPIM

ANAIRAM DE MEDEIROS E SILVA
ANAMARIA SANT'ANNA MURTA

ANAPATRÍCIA MORALES VILHA

ANDERSON ALVES SANTOS

ANDERSON GOMES DE OLIVEIRA

ANDERSON LINO BRAZ DE MACÊDO

ANDERSON LUIZ REZENDE MÓL

ANDERSON MACEDO DE JESUS

ANDERSON QUEIROZ LEMOS

ANDERSON RIBEIRO LEITE

ANDERSON ROBERTO PIRES E SILVA

ANDRÉ ALMEIDA REGGIANI

ANDRÉ DE CASTRO SENA

ANDRÉ DE OLIVEIRA

ANDRE ISAI LEIRNER

ANDRÉ KENREO GOTO

ANDRÉ LUCIRTON COSTA

ANDRÉ LUIS DE CASTRO

ANDRÉ LUIS GOMES

ANDRE LUIS NASCIMENTO DOS

SANTOS

ANDRÉ LUIS NOGUEIRA DA SILVA

ANDRÉ LUIS PEREIRA DUARTE

ANDRE LUIS RABELO CARDOSO

ANDRÉ LUIZ MARQUES SERRANO

ANDRÉ LUIZ ZAMBALDE

ANDRÉ LUZ DE GODOY

ANDRÉ MAGALHÃES

ANDRÉ MEYER COELHO

ANDRÉ MOREIRA PINTO

ANDRE MOURA XAVIER

ANDRE NUNES

ANDRÉ OFENHEJM MASCARENHAS

ANDRÉ PEREIRA DE CARVALHO

ANDRÉ PEREIRA RAPOSO

ANDRE POMPONET

ANDRÉ SPURI GARCIA

ANDREA COSTA VAN HERK

VASCONCELOS

ANDREA CRISTINA DÖRR

ANDREA CRISTINA LUZ BASÍLIO

ANDREA DE OLIVEIRA GONÇALVES

ANDREA FREIRE DE LUCENA

ANDREA LUIZA SESTELO

ANDRÉA MAGALHÃES PIRES

ANDRÉA MÁRCIA SANTIAGO

LOHMEYER FUCHS

ANDRÉA MOREIRA DUARTE ARRAES

ANDREA PAULA DOS SANTOS

ANDREA RIBEIRO DIAS

ANDRÉA RODRIGUES BARBOSA

ANDRÉA SOARES DIAS

ANDRÉA TORRES BARROS BATINGA DE

MENDONÇA

ANDREA VAN HERK VASCONCELOS 
ANDRÉA VENTURA

ANDREA ZELLHUBER TECHNISCHE

ANDRÉCIA MÁRCIA RICARDO DE

CARVALHO

ANDREI PITTOL TREVISAN

ANDRÉIA CRISTINA BARRETO

ANDREIA DE OLIVEIRA SANTOS

ANDREIA DE SOUZA DE CARVALHO

ANDREIA MARIA BERTO

ANDREINA DEL CARMEN CAMERO DE

LIMA

ANDRESSA SILVÉRIO TERRA FRANÇA

ANDREZA DE FÁTIMA COELHO GARCIA

ANDREZA PORTELLA RIBEIRO

ANDREZA SAMPAIO DE MELLO

ANDRIELI DINIZ VIZZOTO

ANGELA CHRISTINA LUCAS

ANGELA CRISTIANE SANTOS PÓVOA

ANGELA CRISTINA ROCHA DE SOUZA

ÂNGELA CRISTINA SALGUEIRO

MARQUES

ANGELA DA VEIGA BELTRAME

ANGELA ELISABETH WEBER

ANGELA LUCAS

ANGELA MARIA MORAIS SILVA

ANGELA MELLO

ANGELA MOULIN SIMÕES PENALVA

SANTOS

ANGÉLICA BAGANHA FERREIRA

ANGÉLICA MARIA ARAUJO CORRÊA

ANGELITA MARIA DOS SANTO

ANGELO SOARES

ANIELSON BARBOSA SILVA

ANIRAM LINS CAVALCANTE

ANNA CAROLINA MOREIRA DE

OLIVEIRA

ANNA CECILIA MENDONÇA AMARAL PETRASSI

ANNA KARINE MONTEIRO DE SOUSA

ANNE LATENDRESSE

ANNE SALMON

ANNELISE BARRETO KRAUSE

ANTONIA LAIS COSTA ARAUJO LEAL

ANTONIA MASCÊNIA RODRIGUES

SOUSA

ANTONIA OLGA CORREIA DE MOURA

ANTÔNIA SILVA

ANTÔNIO ANDRÉ CUNHA CALLADO

ANTÔNIO ARTUR DE SOUZA

ANTONIO CARLOS AIDAR SAUAIA

ANTONIO CARLOS DE MOURA FREDDO

ANTONIO CARLOS FREDDO

ANTONIO CARLOS GIL
ANTÔNIO CARLOS PACAGNELLA

JÚNIOR

ANTONIO CELSO GONÇALVES

PEDROSA

ANTÔNIO COELHO DE SOUZA

NASCIMENTO

ANTÔNIO DA CRUZ PAULA

ANTÔNIO DIMAS CARDOSO

ANTÔNIO DOS SANTOS SILVA

ANTONIO EDUARDO DE

ALBUQUERQUE JUNIOR

ANTONIO FRANCISCO RITTER

FERREIRA

ANTONIO GELIS FILHO

ANTONIO ISIDRO DA SILVA FILHO

ANTÔNIO MARTINS CRUZ

ANTÓNIO ÓSCAR SANTOS GÓES

ANTONIO SÉRGIO TORRES PENEDO

ANTÔNIO SOARES

ANTONIONE CAMELO

APARECIDA MARIA RIBEIRO SILVEIRA

APARECIDO PARENTE

ARIEL LEVY

ARIOVALDO DOS SANTOS

ARLETE APARECIDA DE ABREU

ARLINDO HENRIQUE SAUL DA ROSA

ARMANDO ALEXANDRE COSTA DE

CASTRO

ARMANDO ARAÚJO DE SOUZA JÚNIOR

ARNALDO RYNGELBLUM

ARSÉNIO PAULO

ARTHUR DO AMARAL LAURIANO

ARTUR GOMES DE OLIVEIRA

ARTUR PERRUSI

ASHER KIPERSTOK

ASSIS LUIZ MAFORT OUVERNEY

ÁTILA ALEXIUS

ATILA MARQUES ALVES INDALECIO

ATILIO MACHADO PEPPE

AUCIMAIA DE OLIVEIRA TOURINHO

AUDÁLIO FERNANDES DOS REIS

AUGUSTA COELHO SANTANA

AUGUSTO CÉSAR PINHEIRO DA SILVA

AUGUSTO DE OLIVEIRA MONTEIRO

AUGUSTO JOSÉ DE ABREU ANDRADE

AUGUSTO PAULO GUIMARÃES CUNHA

AULISON ANDRÉ KUMMER

ÁUREA REGINA GUIMARÃES THOMAZI

AURIDETE LIMA FONTELES

AURINEIDE FILGUEIRA ANDRADE

AURISTELA FELIX DE OLIVEIRA

TEODORO

AYALLA CANDIDO FREIRE 
BÁRBARA CUNHA FERREIRA DE

OLIVEIRA

BÁRBARA DA SILVA ROSA

BÁRBARA EDUARDA NÓBREGA

BASTOS

BARBARA HELIODORA VIEIRA

BÁRBARA MATOS MONTEIRO

BARBARA PINHO

BARBOSA GÓES

BEATRIZ ANDRADE DO PATROCÍNIO

BEATRIZ CHRISTO GOBBI

BEATRIZ LANDI LATERZA

BEATRIZ QUIROZ VILLARDI

BENEDICT S. JIMENEZ

BERNADETE BITTENCOURT

BERNARDO KLIKSBERG

BERTRAND SAMPAIO DE ALENCAR

BETH ZIANI

BETINA BELTRAME

BETINA INES BACKES

BIANCA APARECIDA LIMA COSTA

BIANCA POLOTTO CAMBIAGHI

BRENER FIDÉLIS DE SEIXAS

BRENNER LOPES

BREYNER ESTANISLAU SILVA DE

CARVALHO

BRIAN WAMPLER

BRUNA CRUZ DE ANHAIA

BRUNA JHEYNICE SILVA RODRIGUES

BRUNA NEVES CARNELOSSI

BRUNA NOBRE VIEIRA

BRUNA TADIELO ZAJONZ

BRUNA VIANA

BRUNO CUTINHOLA CAVALCANTE

BRUNO DE SOUZA LESSA

BRUNO DIAS MAGALHÃES

BRUNO DIAS SOARES

BRUNO DIEGO ALCANTARA CARDOZO

BRUNO DINIZ LAZARROTTI

BRUNO EDUARDO DE SOUZA

BRUNO FERRARI PAIN

BRUNO RICARDO CARVALHO PIRES

BRUNO SILVEIRA KROEBER VOLPINI

BRUNO VALADARES DE ABREU

BRYAN ROBERTS

CAIO PENKO TEIXEIRA

CAIO PIZA

CAIO RODRIGUES DO VALE

CAMILA AGGIO

CAMILA BORGES

CAMILA CRISTINA DE PAULA PEREIRA

CAMILA CRISTINA RODRIGUES

SALGADO

CAMILA IWASAKI
CAMILA MOREIRA DE CASTRO

CAMILA SILVANA SOUZA E SILVA

CAMILA TOMIO

CAMILE SAHB MESQUITA

CAMILLA CRUZ DE CARVALHO

CAMILLA MARIA CAVALCANTE

GUIMARÃES

CAMILLE MEYER

CAMYLLA CAROLYNA COTTA

CAREN ROSSI

CARINA MOLTER

CARINA RABELO DE SOUZA FONSECA

CARINE DE JESUS SANTOS

CARLA ADELINA CRAVEIRO SILVA

CARLA ARAGÃO

CARLA BEATRIZ MARQUES ROCHA E

MUCCI

CARLA CRISTINA ARRUDA MENEZES

CARLA CRISTINA ROSA DE ALMEIDA

CARLA D. M. SOARES

CARLA DANIELLE COLOIA DE

CARVALHO

CARLA FELLOWS

CARLA GOMES FRANCO

CARLA LILIANE DE MELO FERNANDES

CARLA MOURA

CARLA PASA

CARLA PATRÍCIA BAHRY

CARLA PONTES

CARLA RENATA SANTOS

CARLA ROBERTA SIQUEIRA OLIVEIRA

MARCIANO

CARLOS ADRIANO SANTOS GOMES

CARLOS ALBERTO ARRUDA

CARLOS ALBERTO GABRIELI BARRETO

CAMPELLO

CARLOS ALBERTO PIMENTA

CARLOS ANDRÉ DE MELO ALVES

CARLOS ANTONIO BRANDÃO

CARLOS AUGUSTO HARGER

CARLOS AUGUSTO SANT'ANNA

GUIMARÃES

CARLOS CESAR RIGHETTI

CARLOS DE MEDEIROS DELCIDIO

CARLOS EDUARDO FACIN LAVARDA

CARLOS EDUARDO RODRIGUES

MOREIRA

CARLOS EDUARDO SCHAD

CARLOS EVERALDO SILVA DA COSTA

CARLOS FREDERICO LUCIO

CARLOS HENRIQUE CARDOSO

CARLOS HENRIQUE MENEZES GARCIA

CARLOS HENRIQUE SILVA DE CASTRO

CARLOS MACHADO DE FREITAS 
CARLOS MIELITZ NETO

CARLOS MILANI

CARLOS OLAVO QUANDT

CARLOS ROBERTO THIENGO BOTELHO

CARLOS RODRIGUES DA SILVA

CARLOS ROMAY P. SILVA

CARLOS TEBECHERANI HADDAD

CARLOS Y. SAKURAMOTO

CARLYLE TADEU F. DE OLIVEIRA

CARMEM LIGIA IOCHINS GRISCI

CARMEN AUGUSTA VARELA

CAROLINA BOHORQUEZ HERRERA

CAROLINA DALLA CHIESA

CAROLINA DIAS DE OLIVEIRA ROCHA

CAROLINA FAGUNDES BRINHOLI

CAROLINA FONTES FERREIRA

CAROLINA GUSMÃO MAGALHÃES

CAROLINA LOPES ARAÚJO

CAROLINA ZANATTA

CAROLYNE MACIENTE

CÁSSIA CAROLINA BORGES DA SILVA

CÁSSIA DO CARMO PIRES FERNANDES

CASSIA M P LIMA

CASSIANA MARIS LIMA CRUZ

CASSIANO DE ANDRADE FERREIRA

CASSIANO FERNANDES

CÁSSIO MARCELO SILVA CASTRO

CASTILHOS ROSA MARIA CASTILHOS

CATARINA DA SILVA SOUZA

CATARINA IANNI SEGATTO

CATARINA SILVA SOUZA

CATHERINE ROJAS MERCHÁN

CATIA ELI GEMELLI

CAUE MARTINS FRANCO

CECÍLIA FERRAZ

CECILIA FONSECA E MIRANDA

CECILIA VIANA BELÉM MARINHO

CECILIANO GOMES NETO

CÉDRICK CUNHA GOMES DA SILVA

CELIA REGINA SGANZERLA

CELIANE DIAS DE SOUZA

CELINA BASTO

CELSO EGIDIO LOPES

CELSO MACHADO JÚNIOR

CELSO MIRADA DE CARVALHO

CÉSAR HENRIQUE DE MENDONÇA

CÉSAR TURETA

CESAR VALENTIM DE OLIVEIRA

CARVALHO JÚNIOR

CÉSAR YOJIRO MATSUMOTO

CEYÇA LIA PALEROSI BORGES

CEZAR GUEDES

CHARLES DIAS DE ALMEIDA

CHARLES KIRSCBAUM
CHARLYS SANTOS SIQUEIRA

CHARMAIN LEVY

CHIRSTOPHER ROOTES

CHRIS COOPER

CHRISTIAN MOISES TOMAZ

CHRISTIAN SVOBODA

CHRISTIANA SOARES DE FREITAS

CHRISTIANE BATISTA DE PAULO

LOBATO

CHRISTIANE KLEINÜBING GODOI

CHRISTINE DA SILVA SCHRÖEDER

CIBELE BARSALINI MARTINS

CÍCERA EURISLÂNDIA OLIVEIRA

CÍCERA MÔNICA DA SILVA SOUSA

MARTINS

CÍCERO VALDIER FIDELES SILVA

CIDA SANCHES

CINARA MARIA CARNEIRO ROCHA

CINTHIA BARROS DOS SANTOS

CÍNTHIA MARIA SOUZA E SILVA

CINTHIA SHAMMAH

CÍNTIA CRISTINA KUNZ

CÍNTIA LISIANE DA SILVA RENZ

CÍNTIA MANFREDINI

CINTIA RIBEIRO REIS

CINTIA RODRIGUES

CIRLEIDE DA SILVA RIBEIRO

CIRO ANTÔNIO DA SILVA RESENDE

CIRO BIDERMAN

CLARA ASSUMPÇÃO DE ASSIS LEITE

CLARA CRUZ SANTOS

CLARE SAUNDERS

CLARICE DE SOUZA DUARTE

CLARICE MISOCZKY

CLARICE PEREIRA DE RIBEIRO PAIVA

CLARISSA ISER

CLÁUCIA PICCOLI FAGANELLO

CLAUDEMIR ANDREACI

CLAUDENIR CAROLINO BARBOSA

CLAUDIA BRITO SILVA CIRANI

CLÁUDIA CRISTINA ANDRADE

CLÁUDIA CRISTINA BITENCOURT

CLAUDIA CRISTINA WESENDONCK

CLAUDIA DE FARIA BARBOSA

CLAUDIA DO ESPÍRITO SANTO

CLÁUDIA ECHEVENGUÁ TEIXEIRA

CLAUDIA FORTE

CLÁUDIA HERRERO MARTINS

CLAUDIA MEIRELLES

CLÁUDIA REGINA BADDINI

CURRALERO

CLÁUDIA RIBEIRO PFEIFFER

CLAUDIA SIMONE ANTONELLO

CLAUDIA SIRANGELO ECCEL 
CLÁUDIA SOUSA LEITÃO

CLAUDIA TORRES VOLPON

CLÁUDIA VIEIRA PEREIRA

CLÁUDIO ANTONIO PINHEIRO

MACHADO FILHO

CLÁUDIO ANTÔNIO TORDINO

CLAUDIO BALTAZAR CORREAA DE

MELLO

CLÁUDIO BEZERRA LEOPOLDINO

CLAUDIO DE SOUZA OSIAS

CLAUDIO GURGEL

CLAUDIO LUIZ DE FREITAS

CLÁUDIO NASCIMENTO DIAS GALUCHI

CLAUDIO RAMACCIOTTI

CLEA BEATRIZ MACAGNAN

CLEBER DIAS DA SILVA JÚNIOR

CLEBER SUCKOW NOGUEIRA

CLEBER VIEGAS FERNANDES

CLEBERSON WILLIAMS DOS SANTOS

CLECI GRZEBIELUCKAS

CLÉDIO ROBERTO MARSCHALL

CLEIDSON SANTOS DE JESUS

CLEITON SILVA FERREIRA MILAGRES

CLEZIO SALDANHA DOS SANTOS

CLODILDE CECCATO

CLÓVIS LUIS PADOVEZE

CLÓVIS ROBERTO ZIMMERMANN

CONCEIÇÃO SENA JAQUELINE

CONCEIÇÃO SOUZA

CONRADO GOMIDE DE CASTRO

CORINA ECHAVARRÍA

CRISLANE FIUZA

CRISLANE ISABELA FERREIRA DA

SILVA

CRISTIANE DE CASTRO

CRISTIANE FERREIRA REZENDE

CRISTIANE KERCHES DA SILVA LEITE

CRISTIANE MARQUES DE MELLO

CRISTIANE NATALÍCIO DE SOUZA

CRISTIANE REIS DE SOUZA

CRISTIANE REZENDE

CRISTIANE ROCHA SILVA

CRISTIANE VERCESI CRUCIAL

CRISTIANO COELHO

CRISTIANO DO NASCIMENTO

CRISTIANO ESTANISLAU

CRISTIANO KELLER KESSLER

CRISTIANO RAMOS MOREIRA

CRISTIANO SILVA CARDOSO

CRISTIELE DECKERT

CRISTINA CLARA RIBEIRO PARENTE

CRISTINA DE MIRANDA COSTA

CRISTINA DRUMOND

CRISTINA GERBER JOÃO
CRISTINA LÉLIS LEAL CALEGÁRIO

CRISTINA MARIA MEIRA DE MELO

CRISTINA VELÁSQUEZ

CRISTINE CAMPOS DE CASTRO

CRISTINE FERREIRA GOMES VIANA

CYNTHIA CARNEIRO DE

ALBUQUERQUE SUASSUNA

CYNTHIA GAMBOGI MASSOTE

CYNTHIA MAGALHÃES PINTO GODOI

QUINTÃO

CYNTHIA MARIA BRASIEL DE FILIPPO MENICUCCI

CYNTHIA MEDEIROS DE OLIVEIRA

CYNTHIA XAVIER DE CARVALHO

CYNTIA MEIRELES DE OLIVEIRA

DAFNE OLIVEIRA CARLOS DE MORAIS

DAGOMAR HENRIQUES LIMA

DAIANA CRISTINA PEREIRA

VASCONCELOS

DAIANE APARECIDA DE MELO

DAIANE GOLÇALVES ALVES

DAIANE VITÓRIA DA SILVA

DAIELLY MELINA NASSIF MANTOVANI

DALE KRANE

DALMO DE OLIVEIRA SOUZA E SILVA

DAMIÃO FELIPE CLEMENTE FILHO

DAN FRIEDMAN

DANIEL ANDRADE CARIBÉ

DANIEL ANIJAR DE MATOS

DANIEL BARROSO DE CARVALHO

RIBEIRO

DANIEL BATISTA SUCUPIRA

DANIEL BIN

DANIEL BRUNO GARCIA

DANIEL CARVALHO DE REZENDE

DANIEL DA SILVA FERREIRA

DANIEL ENGELMANN

DANIEL FARIAS

DANIEL JARDIM PARDINI

DANIEL MAGALHÃES MUCCI

DANIEL MARTINS ABELHA

DANIEL MENDES PINTO

DANIEL MORAES PINHEIRO

DANIEL OURIQUES CAMINHA

DANIEL RABELO AMORIM CANDIDO

DOS SANTOS

DANIEL REIS ARMOND MELO

DANIEL RIBEIRO CONDE

DANIEL SIQUEIRA PITTA MARQUES

DANIEL TEODORO GOMES

DANIEL UCHÔA COSTA COUTO

DANIEL WAJNBERG

DANIEL WEI LIANG WANG

DANIELA ANDRADE 
DANIELA APARECIDA ARAÚJO

DANIELA CAMPOS BAHIA MOSCON

DANIELA MEIRELLES

DANIELA SANTOS DA SILVA

DANIELA SILVA

DANIELA THEUER

DANIELE SOARES PAIVA

DANIELE VIDAL LIMA

DANIELI GRANDOTTO FELIPIM

DANIELLE CIRENO FERNANDES

DANIELLE CRISTINE CAVALARI

DANIELLE DA SILVA MENEZ

DANIELLE JACON AYRES PINTO

DANIELLE MANTOVANI LUCENA DA

SILVA

DANIELLE MIRANDA DE OLIVEIRA

ARRUDA GOMES

DANIELLE RODRIGUES DIAS

DANIELLE SANDI PINHEIRO

DANIETE FERNANDES ROCHA

DANILLY RAFAELLY MARTINS CRUZ

DANILO FALBO FONTANESI

DANILO IVO FEITOSA

DANILSON MASCARENHAS VARELA

DANITZA PASSAMAI ROJAS BUVINICH

DANNY PIMENTEL CLARO

DANTE AUGUSTO GALEFFI

DANUSA CUNHA FLORES

DANUZA GUSMÃO G. DE ANDRADE

LIMA

DANYELE QUERÓZ DANTAS

DAVID COSTA SILVA

DAVID ROMEIROS

DAVIDE RAVASI

DAYANE DEBIAN AMARANTE LARA

DAYANE FERREIRA SILVA

DAYANNE MARCIANE GONÇALVES

DAYSA ANDRADE OLIVEIRA

DEBORA AZEVEDO

DÉBORA GONZAGA MARTIN

DÉBORA GUIMARÃES MASULLO

DÉBORA MATOS MAIA

DÉBORA NUNES

DEBORA SANTOS

DEBORAH KELLY NASCIMENTO

PESSOA

DEISE SANTANA DE JESUS BARBOSA

DEISY CRISTINA CORRÊA IGARASHI

DELZA RODRIGUES DE CARVALHO

DENIS ALCIDES REZENDE

DENIS ALVES PERDIGÃO

DENISE GUIMARÃES ROSA

DENISE MACEDO ZILIOTTO

DENISE MACHADO CAMPOS
DENISE MARIA MARTINS

DENISE MARIA MOREIRA CHAGAS

CORREAA

DENISE MATOS

DENISE PIRES BASTO COSTA

DENISE RIBEIRO DE ALMEIDA

DIANA ALVES PRATES SIMÕES

DIANA CRUZ RODRIGUES

DIANA MAGALY CORREA V

DIANA VAZ DE LIMA

DIANE ROSSI MAXIMIANO REINA

DIANE-GABRIELLE TREMBLAY

DIEGO ÁLVARES

DIEGO CAMARGO PIRANI

DIEGO COELHO DO NASCIMENTO

DIEGO COSTA MENDES

DIEGO CRISTOVÃO ALVES DE SOUZA

PAES

DIEGO DE QUEIROZ MACHADO

DIEGO DOMINGOS DE SOUZA

DIEGO GAMA AMARAL

DIEGO GONZALES CHEVARRIA

DIEGO NEVES DE SOUSA

DIEGO RIBEIRO FEITO

DIEGO ROGER RAMOS FREITAS

DIEGO V. G. DEL MÔNICO

DINAH DOS SANTOS TINÔCO

DIÓGENES ALENCAR BOWERCK

DIÓGENES DE SOUZA BIDO

DIOGO DINIZ LOPES SOLA

DIOGO FERRAZ

DIOGO FRANTZ

DIOGO JUNQUEIRA DE CASTRO

DIONYSIO BORGES DE FREITAS JR.

DIRCE KOGA

DIRK MICHAEL BOEHE

DJAIR PICCHIAI

DOMINGOS ARTHUR FEITOSA PETROLA

DOUGLAS BOUZADA

DOUGLAS DE OLIVEIRA BOTELHO

DOUGLAS FERNANDO DOS SANTOS

GODOY

DOUGLAS FILENGA

DOUGLAS MARQUES

DOUGLAS MURILO SIQUEIRA

DUSAN SCHREIBER

EDA CASTRO LUCAS DE SOUZA

EDCLEIDE MARIA DA SILVA

EDENIS CÉSAR DE OLIVEIRA

ÉDER LIRA DE SOUZA LEÃO

EDGARD ALENCAR

EDGARD BARKI

EDI MADALENA FRACASSO

EDILENE PEREIRA BATISTA 
EDIMARA MEZZOMO LUCIANO

EDISON FERNANDES POLO

EDISON QUIRINO D-AMARIO

EDMILSON DE OLIVEIRA LIMA

EDMILSON SOARES CAMPOS

EDNA MARIA CAMPANHOL

EDNÉIA SOARES CASSIMIRO

EDNELSON MARIANO DOTA

EDSON ANTUNES QUARESMA JUNIOR

EDSON CARLOS GERMANO

EDSON CRESCITELLI

EDSON KEYSO DE MIRANDA KUBO

EDSON MARQUES DE OLIVEIRA

EDSON MARTINS DE AGUIAR

EDSON PACHECO PALADINI

EDSON ROBERTO LEITE

EDSON RÔMULO DE SOUSA SANTOS

EDSON RONALDO GUARIDO FILHO

EDSON VICENTE DA SILVA

EDUARDA LORENA DE ALMIDA

EDUARDA MARIA MADEIRA DRAMOS

EDUARDO ANDRADE COUTO

EDUARDO AYROSA

EDUARDO BASSO JÚNIOR

EDUARDO BELFORD R. DE BRITTO

EDUARDO BOTTI ABBADE

EDUARDO DE AQUINO LUCENA

EDUARDO FAUSTO BARRETO

EDUARDO GARCIA

EDUARDO GIRÃO SANTIAGO

EDUARDO GUSMÃO COSTA

EDUARDO HENRIQUE DINIZ

EDUARDO JORGE MARTINS ALVES

SOBRINHO

EDUARDO LACERDA COUTINHO

EDUARDO LOEBEL

EDUARDO MARINO

EDUARDO PAES BARRETO DAVEL

EDUARDO RAUPP DE VARGAS

EDUARDO RENATO ZIMMERLI

EDUARDO SOUZA DE ATHAYDE

EDUARDO TEIXEIRA LEITE

EGLA RAY PASSOS COSTA

EIDER ARANTES DE OLIVEIRA

ELAINE APARECIDA ARAÚJO

ELAINE CRISTINA LICIO

ELAINE DE LIMA ROCHA

ELAINE MENDONÇA BERNARDES

ELAINE PATRÍCIA DE SOUZA OLIVEIRA

ELAINE SILVA RIBEIRO

ELAINE THAIS DA SILVA

ELBA GUIMARÃES VEIGA

ELCEMIR PAÇO CUNHA

ELDER GOMES RAMOS
ELGA LESSA DE ALMEIDA

ELIANA B. M. LOPES

ELIANA CUNICO

ELIANA LEÃO DO PRADO

ELIANA VILEIDE GUARDABASSIO

ELIANE CORRÊA BATISTA

ELIANE DA SILVA BESSA

ELIANE GANEV

ELIANE GONÇALVES

ELIANE PEREIRA ZAMITH BRITO

ELIANE RITA SOLIVO

ELIAS ALVES

ELIAS PEREIRA LOPES JÚNIOR

ÉLIDA SUZETE RAMOS BARBOSA

MONTEIRO

ELIDIANE SUANE DIAS DE MELO

ELÍDIO LUIZ MARTINELLI

ELIELSON CARNEIRO DA SILVA

ELIETH AMÉLIA DE SOUSA

ELIS ROCHA PALMEIRA

ELISA DE JESUS GARCIA

ELISA RODRIGUES ALVES LARROUDÉ

ELISA VERSIANI LUSTOSA

ELISABETH DE OLIVEIRA ANDRADE

ELISABETH MARIA SOUTO WAGNER

ELISAMA CARVALHO DOS SANTOS

ELISANGELA CAIRES

ELISÂNGELA DOMINGUES

MICHELATTO NATT

ELISANGELA FERREIRA CAIRES

ELISE SOERGER ZARO

ELISIANE SARTORI

ELISSANDRA INÁCIO COSTA DE

CARVALHO

ELIZA EMÍLIA REZENDE BERNARDOROCHA

ELIZA REZENDE PINTO NARCISO

ELIZABETE DE ALMEIDA NUNES

ELIZABETE THOMAS

ELIZABETH BORELLI

ELIZABETH FREITAS

ELIZABETH LILIAN FLORES CORREIA

ELIZABETH WOOD MOÇATO DE

OLIVEIRA

ELIZETE SILVA PASSOS

ELMANO PONTES CAVALCANTI

ELMANO RAMALHO CAVALCANTI

ELOISA CABRAL

ELTON OLIVEIRA DE MOURA

ELUAMMI ROCHA MATOS

ELVÉCIO RIBEIRO BRASIL

ELVIRA UCHOA

ELVIS SILVEIRA MARTINS

ELZA FAGUNDES GONÇALVES 
ELZIRA LÚCIA DE OLIVEIRA

EMANOEL MÁRCIO NUNES

EMANUELA OLIVEIRA SPÍNOLA

EMANUELLE COELHO GOMES

EMANUELLE SILVA

EMANUELLE SORAYA COELHO

EMANUELLY ALVES PELOGIO

EMERSON ALCIDES DA SILVA

EMERSON ANTONIO MACCARI

EMERSON TAVARES DA SILVA

EMERSON WAGNER MAINARDES

EMILIE MICHELS

EMMANUEL KENNEDY DA COSTA

TEIXEIRA

ENRIQUE PASTOR SELLER

ÉRIC FORGUES

ÉRICA ALVES MARQUES

ÉRICA BOMFIM BORDIN

ERICA FERREIRA MARQUES

ERICA XAVIER DE SOUZA

ÉRICO CARDOSO PORTO

ÉRIK ÁLVARO FERNANDES

ERIK PERSSON

ERIKA BUZO MARTINS

ERIKA CARACHO RIBEIRO

ERIKA DE ALMEIDA

ERIKA ELAINE CARDOSO DA SILVA

ÉRIKA NOGUEIRA PIROLA

ÉRIKA RIBAS CALDEIRA

ERIKA RÚBIA SOUZA

ERINALDO DIAS VALÉRIO

ERIVANA D'ARC

ERMELINDA SÍLVIA DE OLIVEIRA

LIBERATO

ERNANI OTT

ERNANI VIANA SARAIVA

ERNESTO ALEXANDRE TACCONI NETO

ERNESTO FERNANDO RODRIGUES

VICENTE

ERNESTO M.GIGLIO

EROS E. S. NOGUEIRA

ERVÂNIO FERNANDES MATOS

ESDRAS HOCHE

ESTER ELIANE JEUNON

ESTHER SOLANO GALLEGO

ETIENNE CARDOSO ABDALA

EUCIA BEATRIZ LOPES PETEAN

EUDARDO F. TOPAZIO

EUGÊNIA MARIA ARAÚJO PICKINA

EUGÊNIA ROSA CABRAL

EULER LOPES MENDES

EUNICE L. KWASNICKA

EURICO CELESTINO DOS REIS ARAÚJO

EUZA MARIA DE PAIVA GOMES
EVANDER KRONE

EVANDRO JOSÉ DA CRUZ ARAÚJO

EVANDRO JOSÉ SANTOS RAMOS

EVANDRO LADISLAU

EVANDRO RICARDO RAMOS

EVERLAM ELIAS MONTIBELER

EVERTON BESSA PESSOA

EWERTON ALEX AVELAR

EXPEDITO NUNES

FABIANA CORREIA BEZERRA

FABIANA COSTA E SILVA

FABIANA DA CRUZ LIMA

FABIANA DA SILVA BENTO

FABIANA DE LIMA STEFANOWSKI

FABIANA FERREIRA DA SILVA

FABIANA MORENO DE CAMPOS

FABIANA PEREIRA BARBOSA

FABIANA PIÑARANDA

FABIANA PINTO DE ALMEIDA

BIZARRIA

FABIANA REZENDE ABREU

FABIANA RODRIGUES RIVA

FABIANE BRAZILEIRO PARANHOS

NEVES

FABIANE CORTEZ VERDU

FABIANE DA COSTA E SILVA

FABIANO COTTICA MAGRO

FABIANO LAZAROTTO RAMBO

FABIANO SANTANA DOS SANTOS

FABIELE CÂNDIDO ALMEIDA

FABIEN BLANCHOT

FÁBIO ARAÚJO GOMES

FÁBIO BURIGO

FABIO CESAR DA COSTA ROCHA

FABIO DAL-SOTO

FÁBIO DARCI KOWALSKI

FÁBIO DE OLIVEIRA

FABIO DOS SANTOS CARDOSO

FÁBIO FREITAS SCHILLING

MARQUESAN

FÁBIO GOMES

FÁBIO GRIGOLETTO

FÁBIO JACINTO BARRETO DE SOUZA

FABIO JOSÉ CAPECCHI

FÁBIO JOSÉ MOTA COSTA

FÁBIO LAZZAROTTI

FÁBIO LOTTI OLIVA

FÁBIO LUIZ BENÍCIO MAIA NOGUEIRA

FÁBIO LUIZ MARIOTTO

FABIO MATSUNAKA

FABIO MOLICA DE MENDONÇA

FABIO MOURA COSTA DE SOUZA

FABIO PEREIRA DE ANDRADE

FABIO ROBERTO MORAES LEMES 
FÁBIO SEBASTIANI

FÁBIO SIMÃO DA CUNHA

FABÍOLA CRISTINA COSTA DE

CARVALHO

FABÍOLA CRISTINA RIBEIRO DE

OLIVEIRA

FABÍOLA DE OLIVEIRA ALVARENGA

FABÍOLA MACIEL SARUBBI

FABIULA MENEGUETE VIDES DA SILVA

FABRÍCIO CARVALHO CÍPOLA

FABRICIO FONTES DE ANDRADE

FABRÍCIO HENRIQUE TRINDADE

FABRÍCIO NOURA GOMES

FABRICIO QUADROS BORGES

FABRICIO TAKEO YAMAMOTO

FANY MARIA MONTENEGRO PENAFIEL

FARLEY SIMON NOBRE

FÁTIMA BEATRIZ CARNEIRO TEIXEIRA

PEREIRA FORTES

FÁTIMA CRISTINA TRINDADE

BACELLAR

FÁTIMA DE SOUZA FREIRE

FÁTIMA EVANEIDE B. DE ALMEIDA

FATIMA MARIA FRANZ HERMES

FATIMA MENDES CARVALHO

FÁTIMA PORTILHO

FEDERICO TOBAR

FELIPE DE CASTRO

FELIPE DE PAULA SOUZA

FELIPE KAISER FERNANDES

FELIPE MENDES BORINI

FELIPE MÖLLER NEVES

FELIPE NODARI

FELIPE SILVE LACERDA

FELIPPE LAUER

FERNADA CRISTINA DOS SANTOS

FERNADA FILGUEIRAS SAUERBRONN

FERNANDA AMORIM RIBEIRO DE

CASTRO

FERNANDA BORGES MURAD

FERNANDA CASSAB CARREIRA

FERNANDA CUNHA GARCIA

FERNANDA DANIEL

FERNANDA DE LAZARI CARDOSO

FERNANDA DE LIMA COSTA

FERNANDA DIAS BARTOLOMEU

ABADIO FINCO

FERNANDA FIUZA LIMA

FERNANDA FLORIANO

FERNANDA KRAEMER

FERNANDA LIMA E SILVA

FERNANDA MARIA DE ALMEIDA

FERNANDA MENDES PIRES

FERNANDA MITSUE ONUMA
FERNANDA ONUMA

FERNANDA PIERANGELI FONSECA

FERNANDA QUEIROZ LIMA

FERNANDA REGINA AVIZ

FERNANDA ROSALINA DA SILVA

MEIRELES

FERNANDA SANTOS DE SOUZA AYRES

FERNANDA TARABAL

FERNANDA VERSIANI

FERNANDA VIANNA GURJÃO

FERNANDO ANTONIO FRANCO

MONTORO

FERNANDO ANTONIO GUIMARÃES

TENÓRIO

FERNANDO CARVALHO FAIÃO

FERNANDO CÉSAR BENEVENUTO

MALAFAIA

FERNANDO CURI PERES

FERNANDO DAL RI MURCIA

FERNANDO DO NASCIMENTO LOCK

FERNANDO FACHIN

FERNANDO FERREIRA CALAZANS

FERNANDO FILARDI

FERNANDO FILGUEIRA

FERNANDO JOSE VIEIRA TORRES

FERNANDO JULIAN DE SOUZA FLORIAN

FERNANDO LOTHARIO DA ROZA

FERNANDO MARCELO DE LA CUADRA

FERNANDO MATOS

FERNANDO NATAL DE PRETTO

FERNANDO SOUZA COELHO

FERUCCIO BILICH

FILIPE AMARAL ROCHA DE MENEZES

FILIPE BENSIMON

FILIPE FERNANDES DE PINHO

FILIPE IVO PEREIRA

FILIPE TOSCANO DE BRITO SIMÕES

CORREA

FLAVIA BRAGA NOGUEIRA CUPOLILLO

FLAVIA COUTO RUBACK RODRIGUES

FLÁVIA DE MAGALHÃES ALVIM

FLÁVIA DE SOUZA COSTA NEVES

CAVAZOTTE

FLÁVIA LEÃO ALMEIDA SILVA

FLAVIA MARIA COELHO BAETA-LARA

FLÁVIA MENDES DE ALMEIDA

COLLAÇO

FLAVIA MORI SARTI

FLÁVIA OLIVEIRA RODRIGUES

FLAVIA PEREIRA DE CARVALHO

FLAVIA PEREIRA XAVIER

FLÁVIA VERÔNICA SILVA JACQUES

FLÁVIO ALEXANDRE CARDOSO

ÁLVARES 
FLÁVIO AUGUSTUS DA MOTA

PACHECO

FLÁVIO EIRÓ

FLAVIO MARZADRO

FLORENCE FIUZA DE CARVALHO

FLORIANO JOSÉ GODINHO DE

OLIVEIRA

FRANCELI PEDOTT DIAS

FRANCIANE DE OLIVEIRA ALVARENGA

FRANCIANE REINERT LYRA

FRANCIMAR NATÁLIA SILVA CRUZ

REIS

FRANCIS BERENGER MACHADO

FRANCIS KANASHIRO MENEGHETTI

FRANCISCA FRANCIVÂNIA RODRIGUES

RIBEIRO MACÊDO

FRANCISCA IONE CHAVES

FRANCISCA JOSENAIDE CAMPOS

COSTA

FRANCISCA MÁRQUEZ B.

FRANCISCA NEILIANE BEZERRA

FRANCISCO ANTONIO BARBOSA VIDAL

FRANCISCO CARLOS FERNANDES

FRANCISCO CÉSAR PINTO DA FONSECA

FRANCISCO COELHO MENDES

FRANCISCO CONSTANTINO CROCOMO

FRANCISCO DE ASSIS BREDA

FRANCISCO EZEQUIEL MEDEIROS

FRANCISCO GRANGEIRO TAVARES

NEVES

FRANCISCO JOSÉ DOS SANTOS ALVES

FRANCISCO KLEVENY SORAES DA

SILVA

FRANCISCO LIMA CRUZ TEIXEIRA

FRANCISCO MARCELO GARRITANO

BARONE DO NASCIMENTO

FRANCISCO MARTON GLEUSON

PINHEIRO

FRANCISCO MESQUITA DE OLIVEIRA

FRANCISCO ROBERTO PINTO

FRANCISCO SPEROTTO FLORES

FRANCISCO TIAGO GARCIA PEÑA

FRANCISCO VICENTE SALES MELO

FRANKLIN CARLOS CRUZ DA SILVA

FRANKLIN DIAS COELHO

FRANKLIN TORRES

FRANSCISCO FONSECA

FREDERICO A. DE CARVALHO

FREDERICO DE CARVALHO

FIGUEIREDO

FREDERICO JOSE LUSTOSA DA COSTA

FREDERICO LUIZ BARBOSA DE MELO

FREDERICO LUSTOSA DA COSTA

FREDERICO POLEY MARTINS FERREIRA
FREDERICO ROMAN RAMOS

FREDERICO S. TESCAROLO

FRIDOMAR GUERREIRO DOS REIS

FU KEI LIN

GABRIEL AGUIAR DE ARAÚJO

GABRIEL ALVES PIMENTA

GABRIEL EDUARDO SCHÜTZ

GABRIEL LIMA SIMÕES

GABRIEL MAGALHÃES RODRIGUES

GABRIEL MURAD VELLOSO FERREIRA

GABRIEL RODRIGO

GABRIEL RODRIGO GOMES

GABRIEL WEBBER

GABRIELA CAVALCANTI CUNHA

GABRIELA ESTE PIRES DA ROSA

GABRIELA FRANCISCA MARTINS DE

LIMA

GABRIELA GOULART FERREIRA

GABRIELA NASCIMENTO VALLADARES

MIRANDA

GABRIELA RIBEIRO

GABRIELA TEIXEIRA VIEIRA

GABRIELA TUNES

GABRIELLE MIRANDA NUNES

GASTÃO SOUSA

GEAZI ALVES DE FARIAS

GECELER LEANDRO SENEFONTE

GEMAEL CHAEBO

GEOCIMAR SIMÃO JUSTEN

GEOFFREY I. CROUCH

GEORGE CHRISTIAN LINHARES

BEZERRA

GEORGE ROQUE BRAGA OLIVEIRA

GEORGIA PATRÍCIA DA SIVA

GEORGINA ALVES VIEIRA DA SILVA

GEORGINA GONÇALVES DOS SANTOS

GEOVANA BARDESIO

GERALDINO CARNEIRO DE ARAÚJO

GERALDO DA SILVA GOMES

GERALDO FERNANDES TEIXEIRA

GERALDO MARCIO TIMOTEO

GERLANNE LUIZA SANTOS MELO

GERMAN TORRES SALAZAR

GÉRSON TONTINI

GERUZA TAVARES D'AVILA

GEUSA PURIFICAÇÃO PEREIRA

GEUSIANI PEREIRA SILVA

GEVERSON GRZESZCZESZYN

GEYSON ELIAKIM FERREIRA DE

ARAÚJO

GHISĖLE BAETA FROTA

GIANNA DIAS

GILBERTO CIFUENTES DIAS ARAÚJO

GILBERTO DE MIRANDA ROCHA 
GILMAR JOSÉ DOS SANTOS

GILSON ADAMCZUK OLIVEIRA

GILSON DITZEL SANTOS

GILVANDO SÁ LEITÃO RIOS

GINA RIZPAH BESEN

GIOVAN CARLOS CERON ZORTÉA

GIOVANA GAVA CAMILETTI

GIOVANI VARZIN

GIOVANNI BOHM MACHADO

GIRLAYNNE DANUSIA FARIAS PEREIRA

GIRLENE GALGANI REIS

GISELA ANABEL BARRIONUEVO

GISELE DA SILVA CRAVEIRO

GISELE DE FREITAS

GISELE FERREIRA SOUZA

GISELE HIDALGO

GISELE MENDONÇA FURTADO BASTOS

GISELLE ALVES SILVA

GISELLE FERNANDA MARTINHO COSTA

GISLAINE APARECIDA DA SILVA

SANTANA

GISLAINE MORAES DA FONSECA

GISLEINE LIMA SILVA

GIULIANA ISABELLA

GIULIANO DERROSSO

GLÁDIA LORENA LIMA MAIA

GLAUCE NASCIMENTO

GLÁUCIA MARIA VASCONCELLOS

VALE

GLAUCIENE SILVA MARTINS

GLEDSON ALVES ROCHA

GLEIDE DE FÁTIMA GONÇALVES

GUERRA

GLEÍZA GUERRA DE ASSIS BRAGA

GLENDA MARA ARTHUSO TEIXEIRA

GOBIRRA DE SOUZA-RICARDO

GOMES PESSANHA

GRACE VIEIRA BECKER

GRACIELA CAROLINE GREGOLIN

GRAZIELA XAVIER FORTUNATO

GRAZIELLE ISABELE CRISTINA SILVA

SUCUPIR

GRAZIELLE RIGOTTI DA SILVA

GREG JORDAN ALVES SILVA

GREICE MEDEIROS MARTINS WESSLER

GUILHARDES JESUS JUNIOR

GUILHERME ANDRADE SILVEIRA

GUILHERME AUGUSTO DE OLIVEIRA

CASTRO

GUILHERME BAUMWORCEL

GUILHERME DE FREITAS BORGES

GUILHERME DE QUEIROZ STEIN

GUILHERME DE SOUSA MADUREIRA

SILVA
GUILHERME DE SOUZA MAGALHÃES

GUILHERME ESTEVES

GUILHERME FARIAS

GUILHERME FREITAS BORGES

GUILHERME GOMES KRUEGER

GUILHERME JOSÉ DE VASCONCELOS

SOARES

GUILHERME PEDROSO

GUILHERME QUARESMA GONÇALVES

GUILHERME RODRIGUES OLIVEIRA

GUILHERME SAWATANI GUEDES

ALCOFORADO

GUILLERMO A. CORES

GUILLERMO CRUZ

GUIPSON FONTES PINHEIRO NETO

GUSTAVO ANDREY DE ALMEIDA LOPES

FERNANDES

GUSTAVO BATISTA DE MEDEIROS

GUSTAVO CIARELLI

GUSTAVO DA SILVA MOTTA

GUSTAVO FONTINELLI ROSSÉ

GUSTAVO HENRIQUE NAVES GIVISIEZ

GUSTAVO LEVI TOURINHO FERNANDES

GUSTAVO MORIBE

GUSTAVO XIMENES CUNHA

HAMED MOTAGHI

HAROLDO CLEMENTE GIACOMETTI

HAROLDO TORRES

HARRIE VREDENBURG

HAYDEE CARUSO

HAYDÉE DA CUNHA FROTA

HEBER SILVEIRA ROCHA

HÉCTOR ALIMONDA

HEIKO HOSOMI SPITZECK

HELDER FEITOSA LIBÓRIO ARRAES

HÉLDER SEIXAS LIMA

HELENA CARLA FAGUNDES CAZAES

HELENA CRISTINA TEIXEIRA RONDON

HELENA KARLA BARBOSA DE LIMA

HELENA MARIA GOMES QUEIROZ

HELENA QUEIROZ

HELENA SPINELLI ÁLVARES

HÉLÈNE DEVARENNES

HELIANI BERLATO DOS SANTOS

HÉLIO ARTHUR DOS REIS IRIGARAY

HÉLIO JANNY TEIXEIRA

HELIO RAYMUNDO FERREIRA FILHO

HÉLIO ZANQUETTO FILHO

HELLEN CRISTHINA VAZ DE SOUZA

HELOÍSA GUIMARÃES PEIXOTO

NOGUEIRA

HÉLOÏSE NEZ

HEMERSON ABIBE TAVARES

HENRI CÓCARO 
HENRIQUE CÉSAR MELO RIBEIRO HENRIQUE CÉSAR MUZZIO DE PAIVA BARROSO

HENRIQUE DE BARROS

HENRIQUE DORNAS DUTRA

HENRIQUE FORMIGONI

HENRIQUE GUILHERME CARLOS

HEIDTMANN NETO

HENRIQUE GUIMARÃES

HENRIQUE GUIMARÃES COUTINHO

HENRIQUE TAHAN NOVAES

HERBERT CRISTHIANO PINHEIRO DE

ANDRADE

HERCULIS PEREIRA TOLEDO

HERMAN RESENDE SANTOS

HERMANN ATILA HRDLICKA

HERMANO JOSÉ BATISTA DE

CARVALHO

HERNAN ARMANDO MAMANI

HERNÁN JOSÉ PEROTTI

HERNANI PASSOS CANDIDO

HERON SERGIO MOREIRA BEGNIS

HERRIOT CLOVIS DE CARVALHO FILHO

HIPÓLITA SIQUEIRA DE OLIVEIRA

HIROO TAKAOKA

HORÁCIO HASTENREITER FILHO

HORTÊNCIA GEÓRGIA SANTOS

HUGO CONSCIÊNCIA SILVESTRE

HUGO LEONNARDO GOMIDES DO

COUTO

HUMBERTO RODRIGUES MARQUES

IAN REQUIÃO DE CASTRO

IARA ICÓ

IARÁ MARTINS ICÓ SOUTO

IARA MORENA OLIVEIRA F. E SOUZA

IARA WELLE

ICARO ARONOVICH CUNHA

IDA LUCIANA MARTINS NORILER

IDAIR GIRARDI GUASSELLI

IDGLAN SOUZA MAIA

IGOR VIEIRA PROCÓPIO

ILAN AVRICHIR

ILDEANA AGUIAR ANDRADE

ILSE MARIA BEUREN

ILTON NUNES DOS SANTOS

ILVA NAVARRO BATEMAN

INACILMA RITA SILVA ANDRADE

INÁCIO HELFER

IÑAKI CEBERIO DE LEÓN

INDIARA BELTRAME BRANCHER

INES LYRA COSTA

INGRID PATRÍCIA FERREIRA DA SILVA

INGRID VICTOR

INGRIDI VARGAS BORTOLASO
IOLENE FREITAS DE AZEVEDO

IONÁ Q. NASCIMENTO

IRACEMA LIMA DOS SANTOS

IRME SALETE BONAMIGO

ISAAC MATIAS

ISABEL BALLOUSSIER CERCHIARO

ISABEL CRISTINA SAMPAIO

ISABEL JUREMA GRIMM

ISABEL SAMPAIO ANGELIM

ISABELA ARIANE BUJATO

ISABELA DE OLIVEIRA MENON

ISABELA SARMET DE AZEVEDO

ISABELA TODESCAT

ISABELA WINTER ALMADA ABI-ZAID

ISABELLA FRANCISCA FREITAS

GOUVEIA DE VASCONCELOS

ISABELLA FREITAS GOUVEIA DE

VASCONCELOS

ISABELLE HUAULT

ISADORA DE SOUZA BERNARDINI

ISADORA DE SOUZA LOPES

ISAMARA CORRÊA LEMOS

ISLEIDE ARRUDA FONTENELLE

ISMAEL FERREIRA

ISMAEL ROCHA JR

ISRAEL DE CARVALHO ARAÚJO

ÍTALO CAVALCANTE AGUIAR

ITAMAR DIAS E CORDEIRO

IVAN ANTÔNIO PINHEIRO

IVAN BARRETO DE LIMA ROCHA

IVAN DE SOUZA DUTRA

IVAN PEGORETTI

IVAN ROCHA

IVAN SIDNEY DALLABRIDA

IVAN TRIZI AMORIM

IVANA BENEVIDES DUTRA MURTA

IVANA CARNEIRO ALMEIDA

ÍVINA PEREIRA DA SILVA

IVONE FREIRE COSTA

IVONE LEMKE

IVONE VAZ DE LIMA

IZABEL CRISTINA FERRAZ BARROS

IZABELA RAQUEL

IZAULINA LEITE BENTO

J.R. BRENT RITCHIE

JACIANE CRISTINA COSTA

JACIARA GOMES RAPOSO

JACQUELINE BRIGAGÃO

JACQUELINE ELISA FURTADO

BARRETO DE CARVALHO

JACQUELINE NOGUEIRA CAMBOTA

JADER FERNANDES CIRINO

JADIR VILELA DE SOUSA JUNIOR

JAILDO SANTOS PEREIRA 
JAILZA MENDES DA COSTA JAIRO EDUARDO BORGES-ANDRADE JAIRO JOSÉ ASSUMPÇÃO JAIRO SIMIÃO DORNELAS JALUSA SILVA DE ARRUDA JAMILA COCO RAINHA JAMILA RAINHA JAMILE BARBOZA JAMILE OLIVEIRA SANTOS JAMILLE SANTOS DOS SANTOS LIMA JAMIR MENDES MONTEIRO JAN ALYNE BARBOSA JAN BITOUN JANAINA DE CARVALHO ÁGUIA JANAINA DE MENDONÇA FERNANDES JANAINA PIMENTA ATTIE JANAINA R S DOURADO JANAÍNA SIMÕES JANAYNA SOUZA DA SILVA JANDESON DANTAS DA SILVA JANDIR PAULI JANDIRA PAZZINE PINHEIRO JANDUHY CAMILO PASSOS JANE APARECIDA MARQUES JANE BARBOSA DA ROCHA JANE CRUZ PRATES JANETE LARA DE OLIVEIRA JÂNIA COSME ZANCANELLA JANICE MILENI BOGO JANIELLY COSTA SILVA JANILSON ANTONIO DA SILVA SUZART JANINE FLEITH DE MEDEIROS JANNAN MEDEIROS JANNE ALVES ROCHA JAQUECIELE BALBINOT JAQUELINE ALMEIDA FERREIRA JAQUELINE CLAUDINO DA SILVA JAQUELINE DOS SANTOS GONÇALVES JAQUELINE GUIMARÃES SANTOS JAQUELINE LUÍZA CONCEIÇÃO JAQUELINE SENA JAQUELINE SGANZERLA JAVIER ECHAIDE JAVIER ROJAS JAVIER WALTER GHIBAUDI JEAN CARLOS MACHADO ALVES JEAN CARLOS MENDES DA ROCHA JEAN MARI FELIZARDO JEAN-LOUIS LAVILLE JEANN FABRÍCIO BEZERRA DE MELO JÉFERSON RÉUS DA SILVA SCHULZ JEFFERSON CORDEIRO DE SOUZA JEFFERSON DALL'AGNOL JEFFERSON MENEZES DE OLIVEIRA
JEFFERSON RODRIGUES PEREIRA JEFFESON WILLIAM PEREIRA JEÍCE CATRINE MOREIRA JEISA DA ROCHA COSTA JELISSE VIEIRA GOMES ALMEIDA JEREMY HALL JEROEN WARNER

JÉSICA JÉSICA MAI JÉSSICA BASTOS SAMPAIO JÉSSICA BORGES DE CARVALHO JESSICA CRISTINA ALVES JÉSSICA DE CARVALHO MACHADO JESSICA ELOÍSA DE OLIVEIRA JÉSSICA MÁRA VIANA PEREIRA JÉSSICA PATRÍCIA BERNARDES DA SILVA JÉSSYCA PRISCYLLA DA SILVA COSTA JESUS MARMANILLO PEREIRA JHONATAS LIMA MONTEIRO JOANA VALENTE SANTANA JOANNES PAULUS SILVA FORTE JOÃO AFONSO REIS DOS SANTOS JOÃO ALBERTO RUBIM SARATE JOÃO AUGUSTO RAMOS SILVA JOAO AUGUSTO VARGAS SANTANA JOÃO CARLOS DA CUNHA JOÃO CARLOS GOMES JOÃO CHANG JR JOÃO EDUARDO PRUDÊNCIO TINOCO JOÃO FRANCISCO CARVALHO JOÃO GUALBERTO JOÃO GUILHERME DA SILVA PASSOS JOÃO HEITOR DE AVILA SANTOS JOÃO HENRIQUE PEDERIVA JOÃO MARTINS TUDE JOÃO MATOS FILHO JOÃO MENNA-BARRETO JOÃO PAULO BITTENCOURT JOÃO PAULO DE BRITO NASCIMENTO JOÃO PAULO DE OLIVEIRA LOUZANO JOÃO PAULO SENO JOAO PAULO VIEIRA TINOCO JOÃO SERAFIM TUSI DA SILVEIRA JOAQUIM ALVES DE OLIVEIRA NETO JOAQUIM ANTONILDO PINHO PINHEIRO JOCARLA VITTORAZZI LAQUINI JOCELMA ALMEIDA RIOS JOEDNA LIMA OSES NUNES JOEL SOUTO-MAIOR FILHO JOFRINA ZINAENDA PATRÍCIO JOHN HERBERT BADI ZAPPALA JOICE LIARA BOTH JOICELI DOS SANTOS FABRICIO JOICY PAGANINI DO NASCIMENTO 
JOILDA BEZERRA DOS SANTOS

JONAS CARDONA VENTURINI

JONAS MIRANDA DA SILVA

JONES CARLOS LOUBACK

JONES NOGUEIRA BARROS

JONIAS DOS SANTOS BUENO

JORGE ANTONIO CHAVES DE

OLIVEIRA

JORGE ALBERTO DOS SANTOS

JORGE ANDRÉS POLANCO

JORGE EDUARDO SCARPIN

JORGE EMANUEL REIS CAJAZEIRA

JORGE FERREIRA DA SILVA

JORGE HORÁCIO AUDY

JORGE LHEUREUX DE FREITAS

JORGE LUÍS MORAES DOVAL

JORGE LUIZ AMARAL DE MORAES

JORGE LUIZ VIESENTEINER

JORGE MORAIS MAIA

JORGE PAPADÓPULOS

JORGE WEBER GUIMARÃES BARRETO

JOSÉ RICARDO VARGAS DE FARIA

JOSÉ ALBERTO CARVALHO DOS

SANTOS CLARO

JOSÉ ALBERTO TOZZI

JOSÉ ALEXANDRE FONSECA

JOSÉ ALEXSANDRE FONSECA DA SILVA

JOSÉ ALONSO BORBA

JOSÉ ANGELO MACHADO

JOSÉ ANTÔNIO LACERDA

JOSÉ ANTONIO MONTEIRO HIPÓLITO

JOSÉ ARMÉNIO BELO DA SILVA REGO

JOSÉ ATHADEU JÚNIOR

JOSÉ AUGUSTO DRUMMOND

JOSÉ AUGUSTO VEIGA DA COSTA

MARQUES

JOSÉ BENEDITO PINHO

JOSÉ BITTENCOURT SILVA

JOSÉ BONFIM ALBUQUERQUE FILHO

JOSÉ CARLOS ARAUJO SANTOS JUNIOR

JOSÉ CARLOS DUGO

JOSÉ CARLOS GARÉ

JOSÉ CARLOS SALLES

JOSÉ CARLOS ZANELLI

JOSÉ DE ANDRADE SILVA FILHO

JOSÉ DE LIMA ALBUQUERQUE

JOSÉ DIONÍSIO GOMES DA SILVA

JOSÉ EDSON MOISÉS

JOSÉ EDUARDO FERNANDES

JOSÉ EDUARDO STOROPOLI

JOSE ELENILSON CRUZ

JOSÉ ESTEBAN CASTRO

JOSÉ FERREIRA IRMÃO

JOSÉ ISIDIO DE FREITAS COSTA
JOSÉ IVO FOLLMANN

JOSÉ JOAQUIM NETO CISNE

JOSÉ JORGE ABRAIM ABDALLA

JOSÉ JORGE SOUSA CARVALHO

JOSÉ LINDOVAL LIMA MATOS

JOSÉ LUIS DUARTE RIBEIRO

JOSÉ LUIS VIANNA DA CRUZ

JOSÉ LUIZ MOREIRA DE CARVALHO

JOSÉ MARIA BERNARDELLI JUNIOR

JOSÉ MURILO PHILIGRET BAPTISTA

JOSÉ NORBERTO MUNIZ

JOSÉ ODELSO SCHNEIDER

JOSÉ RENATO DA SILVA ABREU

JOSE RENATO SANT'ANNA PORTO

JOSÉ RICARDO COSTA DE MENDONÇA

JOSÉ RICARDO FAVORETTO

JOSÉ ROBER PEREIRA

JOSÉ ROBERTO

JOSÉ ROBERTO SEVERINO

JOSÉ ROGÉRIO LOPES

JOSÉ RUBENS MONTEIRO TEIXEIRA

JOSÉ SANTOS DE JESUS

JOSÉ VERÍSSIMO ROMÃO NETTO

JOSEANE LIMA

JOSENILDA RODRIGUES DE LIMA

JOSENILDO COELHO TEODORO

JOSENILDO DOS SANTOS

JOSENON GOMES COSTA

JOSIANE BARBOSA GOUVÊA

JOSIANE DE ANDRADE PEREIRA

JOSINEIDE SOUSA OLIVEIRA

JOSINÊS BARBOSA RABELO

JOSUÉ BARROS JÚNIOR

JOYCE ARANTES CARVALHO

JOYCE DA SILVA ALBURQUERQUE

JOYCE GESUÍLO GONÇALVES

JOYCE MARIA RODRIGUES

JOYCE SANTANA BERNARDO

JOYCE SOUSA SELVATTY

JUAN IGNACIO BRIZUELA

JUAREZ PAULO TRIDAPALLI

JUCINEIA TAVARES DA SILVA

JÚLIA DRUMOND CAMPOS E SILVA

JÚLIA MORETTO AMÂNCIO

JÚLIA TAIS CAMPOS RIBEIRO DE

OLIVEIRA

JULIA VAZ LORENZETTI

JULIANA AZEVEDO DE SOUZA CARIBÉ

JULIANA BARBOSA ZUQUER GIARETTA

JULIANA BERNIERI

JULIANA DE FREITAS ALVES

JULIANA DURAYSKI

JULIANA FIGALE

JULIANA GERTRUDES BORGES 
JULIANA GIRALDI PASSOS

JULIANA GOULART SOARES DO

NASCIMENTO

JULIANA GUARANÁ VIEIRA MAIA

JULIANA MARQUES FIGALE

JULIANA NUNES DE ALCÂNTARA

JULIANA NUNES MOREIRA

JULIANA NUNES PEREIRA

JULIANA OLIVEIRA BRESCHIGLIARI

JULIANA PORCIÚNCULA

JULIANA PREVIATTO BALDINI

JULIANA RODRIGUES SAMPAIO

JULIANE JENNRICH

JULIANE SACHSER ANGNES

JULIANNE ALVIM MILWARD

JULIANO FROEHNER

JULIANO LUIS BORGES

JULIANO NUNES ALVES

JULIANO SOUSA MATOS

JULIENE AGLIO OLIVEIRA

JULIENE BARBOSA FERREIRA

JÚLIO ADRIANO FERREIRA DOS REIS

JÚLIO CÉSAR BASTOS DE FIGUEIREDO

JULIO CESAR DE S. LOUREIRO

JULIO CESAR GOMES

JULIO ERNESTO COLLA

JÚLIO F. B. FACÓ

JULIO ROCHA

JUNE ALISSON WESTARB CRUZ

JUSSARA CARNEIRO COSTA

JUSSARA RÊGO

JYLDYZ KASYMOVA

KADMA LANUBIA

KALIANE CALDAS DE BRITO MACHADO

KAMI TIBA BAPTISTA

KAMILLA ALVES RODRIGUES

FERREIRA

KAREN CHRISTINE DIAS GOMES

KAREN LOPES PERROTTA DE ALMEIDA PRADO

KAREN MENGER DA SILVA

KAREN PERROTTA LOPES DE ALMEIDA

PRADO

KAREN SASAKI

KAREN VIEIRA RAMOS

KARINA DAMIÃO HIRANO

KARINA FURTADO RODRIGUES

KARINE CONCEIÇÃO DE OLIVEIRA

KARINE SOUSA JULIÃO

KARLA CHRISTINA NEVES DE SOUZA

KARLA ROSSANA GOMES LOBO

KARLAN RAU

KASPAR VILLADSEN

KATE DAYANA RODRIGUES DE ABREU
KATIA LENE DE ARAÚJO LOPES

KÁTIA MARIA PEREIRA BRASIL

KATIA REGINA CARLESSO

KAZUO HATAKEYAMA

KEILE BERALDO

KEITILINE RAMOS VIACAVA

KELLEN LAZZARETTI

KELLI CRISTINA DACÓL

KELLY APARECIDA TORRES

KELLY CRISTINA SILVA

KENNETH NUNES TAVARES DE

ALMEIDA

KENNY BASSO

KENYS MENEZES MACHADO

KETELEN GUIMARÃES

KETLLE DUARTE PAES

KEURYANNE GUERREIRO DOS REIS

KEYSA MANUELA CUNHA DE

MASCENA

KIARA ZANCANARO MOTTER

KILNER GUILHERME FERREIRA

KLAUS PEREIRA DA SILVA

KLEBER CAVALCANTI NÓBREGA

KLEVER EFRAIIN NARANJO BORJA

KLINGER ARAGÃO

KONSTANTIN GERBER

KWANNY ALVES FOLGADO

KYARA VASQUES SILVA

KYRIAM MARIANE BORGES

MAGALHÃES

LAANE LIMA QUEIROZ

LAERCIO BAPTISTA DA SILVA

LAILA CRUZ FRAGA

LAILA RAIANA SANTANA BORGES

LAILA SUELEN JORGE

LAÍS ALBUQUERQUE DE CARVALHO

LAÍS ÁLVARES ASSIS

LAIIS BARBOSA ANZOLIN

LAIS KEIKO RIBEIRO NAKAGAKI

LAIIS SANTOS LIMA

LAISE COPOLILLO AYRES

LAMARTINE PEREIRA BAETA FILHO

LARA ELENA RAMOS SIMIELLI

LARA LÚCIA DA SILVA

LARA SOUSA MATOS

LARISSA BARBOSA DA SILVA

LARISSA BENNER GÖHRING

LARISSA BRANDELLI BUCCO

LARISSA CRISTINA DAL PIVA MOREIRA

LARISSA DE PAOLIS SILVA

LARISSA ESTELA BEREHULKA BALAN

LEAL

LARISSA HADDAD SOUZA VIEIRA

LARISSA SANTOS LIMA 
LARISSE CHRISTINE DE OLIVEIRA

FERREIRA

LARISSE KUPSKI

LAUDICÉIA NUNES DA SILVA

GONÇALVES

LAUDICÉIA SILVA

LAURA FERREIRA MACÊDO

LAURA LETSCH SOARES

LAURA MARIA BRITO DE MEDEIROS

LAURA MARTINI ZELLMEISTER

LAURA MOMBELLO

LAURA REZENDE FUSER

LAURA SANTUCCI

LAURE DAUDIN

LAURO GONZALEZ

LAVINIA PESSANHA

LEANDRA FERNANDES DO

NASCIMENTO

LEANDRO ALVES PATAH

LEANDRO NEUHAUS

LEANDRO RESENDE FREITAS

LEANDRO VIANNA SILVA SOUZA

LEANDRO VIEIRA SILVA MATOS

LEANE MOTA ARAUJO DOS SANTOS

LEDA CRISTINA SANTOS DOS REIS

LEIDIMAR CANDIDA DOS SANTOS

LEILA DIAS PEREIRA DO AMARAL

LEILA GIANDONI OLLAIK

LEILA MÁRCIA SOUSA DE LIMA ELIAS

LEILA VAZ DA SILVA

LEILANY ALINE LOPES DE OLIVEIRA

LEILIANNE MICHELLE TRINDADE DA

SILVA

LENIN CAVALCANTI BRITO GUERRA

LEO TADEU ROBLES

LEONARDO AUGUSTO AMARAL TERRA

LEONARDO AUGUSTO GÓMEZ

CASTILLO

LEONARDO BRASIL CARVALHO

LEONARDO COELHO DE OLIVEIRA

LEONARDO CONCEIÇÃO CRUZ

LEONARDO DA SILVA MORAIS

LEONARDO DE MIRANDA SIQUEIRA

LEONARDO DIAS AFONSO

LEONARDO FABRIS LUGOBONI

LEONARDO LACERDA

LEONARDO LEMOS DA SILVEIRA

SANTOS

LEONARDO PEREIRA KURIHARA

LEONARDO PRATES LEAL

LEONARDO SECCHI

LEONARDO SOLARTE-PAZOS

LEONARDO TORRES TEIXEIRA LEITE

LEONARDO VALADÃO NUNES TORRES
LEONEL CEZAR RODRIGUES

LEONICE PARNOFF

LEOZINA BARBOSA DE ANDRADE

LETÍCIA ARAUUJO DE CARVALHO

LETÍCIA DALLA BRIDA DA SILVEIRA

LETÍCIA GOULART DOS SANTOS

TESSMANN

LETÍCIA LENGLER

LETICIA PALMA CAMARGO

ROUMELIOTIS

LETÍCIA QUEIROZ DE CARVALHO

LEYLIANNE ALVES VIEIRA

LIA BORGES DE MATTOS CUSTÓDIO

LIA DE AZEVEDO ALMEIDA

LIA SALES SERAFIM

LIBERTAD JIMÉNEZ ALMIRANTE

LÍDIA RAFAELA BARBOSA DOS SANTOS

LIDIANE NAZARÉ DA SILVA DIAS

LÍDIO DE SOUZA

LÍGIA CACIDA MARIA ANDRÉ ZAQUEU

LÍGIA CRISTINA AMARAL MAGALHÃES

LÍGIA MARGARIDA GOMES DE JESUS

LÍGIA MARIA FRANÇA CARDOSO

LIGIA MAURA COSTA

LILIA APARECIDA KANAN

LILIAN ALFAIA MONTEIRO

LÍLIAN BARROS PEREIRA

LÍLIAN BEATRIZ FERREIRA

LILIAN BRUM DUARTE DAVI

LILIAN CAMPAGNIN LUIZ

LÍLIAN CAPORLÍNGUA GIESTA

LÍLIAN DE CARVALHO LINDOSO

LILIANE CANOPF

LILIANE CARACIOLO FERREIRA

LILIANE CRISTINA SEGURA

LILIANE DE QUEIROZ ANTONIO

LILIANE MOSER

LINA PAOLA RUBIO

LINARA FERREIRA PORTO

LINDALVA GOUVEIA NASCIMENTO

LINDEMBERG MEDEIROS DE ARAÚJO

LINDINALVA DOS SANTOS

LINDSAY KEROLLE GUIMARÃES

SOARES

LISA BARCELOS OLIVEIRA REZENDE

LISANDRA DOS SANTOS ZORZELLA

LISIANE CELIA PALMA

LISSANDRA NAZARETH DE CARVALHO

LÍVIA CASTELLO BRANCO

LÍVIA GARCEZ DE OLIVEIRA PADILHA

LIZE MARIA SOARES BARROCO

LOHAINE JARDIM BARBOSA

LORENA CAMPOS SILVEIRA

LORENA ROOSEVELT DE LIMA ALVES 
LUANA DE FÁTIMA ALMEIDA

LUANA DOS SANTOS HANAUER

LUANA FERREIRA DOS SANTOS

LUANA PINHEIRO

LUCAS BORGES KAPPEL

LUCAS CASALE DO NASCIMENTO

LUCAS FARIAS ZARCONI CAVALCANTI

DUARTE

LUCAS JUNQUEIRA MACIEL VELOSO

LUCAS LOUREIRO DE BARROS LIMA

LUCAS MARKOWICZ BASTOS

LUCAS PIMENTA SILVA PAIVA

LUCAS POUBEL TIMM DO CARMO

LUCAS ROSA PAIVA

LUCAS SILVA BORGES DE ANDRADE

LUCAS SILVESTRE DE CARVALHO

LUCAS VEIGA ÁVILA

LUCAS ZARCONI

LUCIA BARBOSA DE OLIVEIRA

LÚCIA CONY FARIA CIDADE

LUCIA CRISTINA DOS SANTOS ROSA

LÚCIA DE FÁTIMA BARBOSA

MAGALHÃES MORAES

LÚCIA HELENA DA SILVA

LUCIA HELENA NILSON

LÚCIA MARIA AQUINO DE QUEIROZ

LUCIA SILVA KUBRUSLY

LUCIANA ALBUQUERQUE ALVES

LUCIANA APARECIDA BARBIERI DA

ROSA

LUCIANA ARAUJO DE HOLANDA

LUCIANA BRAGA SILVEIRA

LUCIANA COSTA FREITAS DIAS

LUCIANA CUSTÓDIO

LUCIANA DAVI TRAVERSO NODARI

LUCIANA DE OLIVEIRA MIRANDA

GOMES

LUCIANA ELMAIS

LUCIANA FERREIRA DOS SANTOS

LUCIANA FLORES BATTISTELLA

LUCIANA GRAZIELA ARAUJO CUOCO

LUCIANA HARUMI HASHIBA HORTA

LUCIANA HENDGES

LUCIANA IWASHITA DA SILVA

LUCIANA LEITE LIMA

LUCIANA LELIS LEAL

LUCIANA LIMA

LUCIANA LIMA GUILHERME

LUCIANA LUNELLI

LUCIANA MAINES DA SILVA

LUCIANA MARQUES VIEIRA

LUCIANA MARTINS EZEQUIEL SOUSA

LIMA
LUCIANA MORAES RASO SARDINHA

PINTO

LUCIANA ORANGES CEZARINO

LUCIANA PINTO

LUCIANA SANTOS COSTA VIEIRA DA

SILVA

LUCIANA SILVA CUSTÓDIO

LUCIANA SOUSA REMIÃO SÁ

LUCIANA STOCCO BETIOL

LUCIANE FERREIRA CARDOSO

LUCIANE MARIA GONÇALVES FRANCO

LUCIANE NEVES BARBOSA

LUCIANO ALBERTO FERREIRA

LUCIANO ANGELO FRANCISCO KAREL

NÁPRAVNÍK FILHO

LUCIANO FERREIRA

LUCIANO FRANCISCO SILVEIRA DA

SILVA

LUCIANO HENRIQUE FIALHO BOTELHO

LUCIANO OLIVEIRA DOS SANTOS

LUCIANO QUINTELLA

LUCIANO SATHLER

LUCIANO SERGIO MICHELAN

LUCIANO SILVA

LUCIENE SALES SENA

LUCILENE DE CASSIA SANTOS

CÂNDIDO

LUCILIA DA GLÓRIA TOMAZILLI

LUCIMAR DA SILVA ITELVINO

LUCIMARA ALEXANDRE DA SILVA

LUDMEIRA MEIRA

LUDMILA CÂNDIDO ANTUNES

PARREIRA

LUDMILA MARIA BATISTA DE BRITO

RIBEIRO

LUDMILA MOTA SANTOS

LUÉCIA SILVA

LUÍS ABEL DA SILVA FILHO

LUIS CARLOS FERREIRA DE SOUSA

OLIVEIRA

LUIS FELIPE MACHADO DO

NASCIMENTO

LUIS FERNANDO FILARDI FERREIRA

LUIS MARCELO ANTONIALLI

LUIS PERES AZEVEDO

LUIS TADEU DOS SANTOS ANDRADE

LUÍSA AGOSTINHO

LUÍSA MAHIN ARAÚJO LIMA DO

NASCIMENTO

LUISA MARIA RODRIGUES DINIZ

LUISA MATOS DE BARROS CORREIA

LUIZ ALBERTON

LUIZ ANTÔNIO GOUVEIA DE OLIVEIRA

LUIZ ANTONIO JOIA 
LUIZ ANTONIO STAUB MAFRA

LUIZ CARLOS HONÓRIO

LUIZ CÉLIO SOUZA ROCHA

LUIZ CLAUDIO MARQUES CAMPOS

LUIZ CLÁUDIO SANTOS

LUIZ DOS SANTOS LINS

LUIZ EDUARDO MOTTA

LUIZ FELIPE VILELA PINTO

LUIZ FERNANDO DE LIMA

LUIZ FERNANDO DE ORIANI E

PAULILLO

LUIZ FLAVIO AUTRAN MONTEIRO

GOMES

LUIZ GONZAGA DE CASTRO JÚNIOR

LUIZ GUSTAVO LIBÓRIO VIANNA

LUIZ GUSTAVO MEDEIROS BARBOSA

LUIZ GUSTAVO SANTANA

LUIZ HENRIQUE DE BARROS VILAS

BOAS

LUIZ HENRIQUE RODRIGUES DA SILVA

LUIZ MORETTO NETO

LUIZ NORBERTO MAGALHÃES FILHO

LUIZ RICARDO DE SOUZA

LUIZ RICARDO MATTOS TEIXEIRA

CAVALCANTE

LUIZ RICARDO TIBALI

LUIZ VICTOR PITTELLA SIQUEIRA

LUÍZA RIBEIRO FAGUNDES

LUIZA SABINO QUEIROZ

LUIZA SCHULTZ RAMOS

LUIZA SILVA BUENET

LUZ FERNANDEZ

LUZ FERNANDEZ GARCÍA

LUZIA BUCCO COELHO

LUZIA COSTA BECKER

LYA CYNTHIA PORTO DE OLIVEIRA

LYOVAN NEVES MAFFIA

LYS MARIA VINHAES DANTAS

MABEL BASTOS DE PAULA

MADILEIDE ROCHA DOS SANTOS

MAGALI APARECIDA MEDEIROS DIAS

MAGDA DE LIMA LÚCIO

MAGNO VALENÇA DE BARROS

MAIBY CARESTIATO FROSSARD

MAICON NISHIMURA

MAIKO THADEU CARDOSO DE SOUZA

MAIRA CINQUINI JUNQUEIRA

MAÍRA DA CUNHA PINTO COLARES

MAÍRA FONTENELE SANTANA

MAÍRA MARIA DA NOBREGA SOUZA

MAIRA PETRINI

MAIRA RUBINI RUIZ

MAÍSA OLIVEIRA MELO FERRAZ

MALI TERESINHA KUNZLER
MALOE BOSCH

MALU VILELLA

MANOEL PEDRO VIEIRA FILHO

MANUEL ANTONIO MEIRELES DA

COSTA

MANUEL RUAS PEREIRA COELHO

BONDUKI

MANUELA C. ALBUQUERQUE KLEIN

MANUELA TRINDADE VIANA

MARA ALVES SOARES

MARC HOLZER

MARCEL CARDOSO FERREIRA DE

SOUZA

MARCEL LUCIANO KLOZOVSKI

MARCELA FERNANDES GASPARINO

MARCELA MENEZES COSTA

MARCELA MOURA BASAGLIA

MARCELA NOGUEIRA

MARCELLA C. A. SCOTTI

MARCELLA CORRÊA GOMES

RODRIGUES

MARCELLO MONTEIRO PEREIRA

MARCELLO VEIGA

MARCELLO VINICIUS DORIA CALVOSA

MARCELO ABI-RAMIA CAETANO

MARCELO ANTÔNIO CONTERATO

MARCELO AURELIANO MONTEIRO DE

ANDRADE

MARCELO BINE MONI

MARCELO BOSCHI

MARCELO CABUS KLOTZLE

MARCELO COSTA CALDAS

MARCELO DA SILVA SCHUSTER

MARCELO DANTAS

MARCELO DE OLIVEIRA GARCIA

MARCELO EDUARDO LEITE

MARCELO ERNANDEZ

MARCELO FERREIRA VIANA

MARCELO HENRIQUES DE

ALBUQUERQUE PESSOA

MARCELO KUNRATH SILVA

MARCELO LEANDRO DE BORBA

MARCELO LUIZ DIAS DA SILVA

GABRIEL

MARCELO MÁRCIO ROMANIELLO

MARCELO NEY DE JESUS PAIXÃO

MARCELO PIRES ROSAS

MARCELO REINECKE

MARCELO ROSSAS FREIRE FILHO

MARCELO TREFF ARTIGO

MARCELO TYSZLER

MARCELO ZANDOMINGUE MONTI

MARCELO ZEPKA BAUMGARTEN

MÁRCIA ANDRÉIA SCHNEIDER 
MARCIA APARECIDA ZAMPIER

MÁRCIA BEATRIZ AMARAL

MÁRCIA CONCEIÇÃO

MÁRCIA CRISTINA CASTANHARI

MANDELI

MÁRCIA CRISTINA GOMES DA ROCHA

MARCIA DUTRA DE BARCELLOS

MÁRCIA ELIANA MARTINS

MARCIA F D SOUZA

MÁRCIA FERREIRA

MÁRCIA GANEM

MÁRCIA GOLFIERI

MÁRCIA GOMES DUARTE

MARCIA JOSEFA BEVONE COSTA

MARCIA JULIANA D'ANGELO

MÁRCIA LOPES CARDOSO

MARCIA LUANA MOREIRA DE SOUZA

MÁRCIA MARA MARINHO

MÁRCIA MAZZEO GRANDE

MÁRCIA RAMOS MAY

MÁRCIA REGINA FARIAS DA SILVA

MÁRCIA REGINA VICTORIANO

MÁRCIA ROSANE FREY

MÁRCIA SILVA LEÃO

MÁRCIA ZABDIELE MOREIRA

MARCIELE BERGER BERNARDES

MÁRCIO ANDRÉ DE CARVALHO

MARCIO BAUER

MARCIO BORGES

MÁRCIO DE ALBUQUERQUE VIANNA

MARCIO DE OLIVEIRA MOTA

MARCIO EDUARDO BROTTO

MARCIO FERNANDO PINHEIRO

MARCIO GOMES DE SÁ

MARCIO KUNIYOSHI

MARCIO MANOEL TEIXEIRA

MARCIO SILVA RODRIGUES

MARCO ANDRÉ ASSAN

MARCO ANTONIO CONEJERO

MARCO ANTONIO VILLARTA-NEDER

MARCO AURÉLIO AFONSO ABREU

MARCO AURÉLIO ARBAGE LOBO

MARCO AURÉLIO RUEDIGER

MARCO CÉSAR RIBEIRO NASCIMENTO

MARCO CREMASCHI

MARCONDES LOMEU BICALHO

MARCOS ALENCAR ABAIDE

BALBINOTTI

MARCOS ANDRÉ MENDES PRIMO

MARCOS AURÉLIO DE ARAÚJO

FERREIRA

MARCOS BAPTISTA LOPEZ DALMAU

MARCOS BARUKI SAMAHA
MARCOS BIDART CARNEIRO DE

NOVAES

MARCOS CORTEZ CAMPOMAR

MARCOS DE CASTRO

MARCOS EDUARDO ZAMBANINI

MARCOS FAVA NEVES

MARCOS FEITOSA

MARCOS LORENZELLI

MARCOS PAULO DA SILVA

MARCOS PIELLUSCH

MARCOS PROCÓPIO

MARCOS ROBERTO PIRES GREGOLIN

MARCOS TAKAO OZAKI

MARCOS TANURE SANÁBIO

MARCOS TAROCO RESENDE

MARCOS VINICIO BILANCIERI

MARCOS VINICIUS PÓ

MARCOS VINICIUS ROMÃO DA SILVA

XAVIER

MARCUS V. SANT'ANNA

MARCUS VINÍCIUS ALVES FINCO

MARCUS VINÍCIUS ANDRADE LIMA

MARCUS VINICIUS CARVALHO

FAGUNDES

MARCUS VINICIUS DAVID

MARCUS VINICIUS DE OLIVEIRA

BRASIL

MARCUS VINICIUS DE SOUZA

MARCUS VINICIUS GONÇALVES DA

CRUZ

MARCUS VINÍCIUS OLIVEIRA

MARCUS VINÍCIUS P. GOMES

MARCUS VINICIUS SOARES SIQUEIRA

MARCUS VINICIUS VERAS MACHADO

MARGARETE DIAS DE BRITO

MARIA AUXILIADORA DE MORAES

MOREIRA

MARIA ISABEL DA SILVA AZEVEDO ALVIM

MARIA ABADIA DA SILVA ALVES

MARIA ADILMA DE FIGUEIREDO

MARIA ALBERTINA SCHMITZ BONIN

MARIA ALEXANDRA CUNHA

MARIA ALICE CRUZ ALENCASTRO

MARIA AMÉLIA RODRIGUES DA SILVA

MARIA ANGÉLICA MACIEL COSTA

MARIA ANTÔNIA DA COSTA

MARIA ANTONIETA LEOPOLDI

MARIA APARECIDA FERREIRA DE

AGUIAR

MARIA APARECIDA FORTES DE

ALMEIDA PRESIDIO

MARIA APARECIDA NETO DA CRUZ

MARIA APARECIDA SANCHES 
MARIA AUXILIADORA DINIZ DE SÁ MARIA BIANCA PINHEIRO DE MOURA MARIA CAROLINA CONEJERO MARIA CAROLINA SERPA FAGUNDES DE OLIVEIRA

MARIA CECILIA COUTINHO DE ARRUDA

MARIA CECÍLIA LOSCHIAVO DOS SANTOS

MARIA CECILIA PINTO MARQUES MARIA CECÍLIA PRATES RODRIGUES MARIA CECÍLIA SOBRAL MARIA CHALFIN COUTINHO MARIA CLARA VIEIRA WEISS MARIA CONCEIÇÃO MELO SILVA MARIA CRISTINA DE ABREU REIS MARIA CRISTINA FERREIRA MARIA CRISTINA FOGLIATTI DE SINAY MARIA CRISTINA LEAL DE CARVALHO VIEGAS

MARIA CRISTINA LUNARDI KERN MARIA CRISTINA RODIGUES RESENDE MARIA DA GLÓRIA ARRAIS PETER MARIA DA GLÓRIA CARDOSO FERREIRA MARIA DA GLORIA MARCONDES GOHN MARIA DA GLÓRIA PEREIRA MARIA DA GLÓRIA VITÓRIO GUIMARÃES

MARIA DA GRAÇA DE OLIVEIRA CARLOS MARIA DA GRAÇA PITIÁ BARRETO MARIA DAS GRAÇAS DE OLIVEIRA SANTIAGO

MARIA DAS GRAÇAS MORENO SOLEDADE FONTES MARIA DE FÁTIMA MARIA DE FÁTIMA ARAÚJO FRAZÃO MARIA DE FÁTIMA ARAÚJO TELES MARIA DE FÁTIMA BRUNO-FARIA MARIA DE FÁTIMA C. D. ALEXANDRE MARIA DE FATIMA CAVALCANTE TOSINI

MARIA DE FÁTIMA D. C. ALEXANDRE MARIA DE FÁTIMA DAVID MARIA DE FÁTIMA DE OLIVEIRA SOBREIA

MARIA DE FATIMA FORTES

MARIA DE FÁTIMA LOPES

MARIA DE FÁTIMA NÓBREGA

BARBOSA

MARIA DE FÁTIMA ROCHA GONDIM MARIA DE LOURDES DE AZEVEDO BARBOSA
MARIA DE LOURDES DE CARVALHO MARIA DE LOURDES PINHEIRO DA SILVA

MARIA DE LOURDES SIQUEIRA MARIA DE NAZARÉ MORAES SOARES MARIA DO CARMO LESSA GUIMARÃES MARIA DO CARMO REIS MARIA DO ROSARIO CORREAA DE SALLES GOMES MARIA DO ROSÁRIO DE FÁTIMA E SILVA MARIA DO SOCORRO BARBOSA GUEDES

MARIA DO SOCORRO SILVA MESQUITA MARIA ELIZABETH BORGES MARIA ELVIRA ROCHA DE SÁ MARIA ÉRICA DE LIRA SANTOS MARIA FLAVIA BASTOS DUARTE MARIA GABRIELA ARAÚJO DOS SANTOS

MARIA GILDIVANE SOARES DA SILVA MARIA GORETE DA SILVEIRA TAGLIARI HOFFMANN

MARIA GRAZIA EGIDIA GORLA JUSTA MARÍA GUADALUPE SERNA MARIA INÊS CAETANO FERREIRA MARIA INÊS DE FRANÇA ROLAND MARIA INÊS DO CARMO MARIA IRAÊ DE SOUZA CORREAA MARIA ISABEL SOUSA BEZERRA MARIA IZABEL MARQUES DO VALLE MARIA JANILELLY DA COSTA E SILVA MARIA JOÃO NICOLAU SANTOS MARIA JOSÉ CARVALHO DE SOUZA DOMINGUES

MARIA JOSÉ DE OLIVEIRA CARVALHAL MARIA JOSÉ DE SOUZA BARBOSA MARIA JOSE SILVA MARIA JULIA AZEVEDO GOUVEIA MARIA JULIETA NUNES MARIA LETICIA BARBOSA XAVIER MARIA LÚCIA CUNHA CARVALHO MARIA LUIZA AMARAL RIZOTTI MARIA MAGDALENA ALVES MARIA MÁIRA NÓBREGA SOUSA MARIA MATILDE ZRAIK BARACAT MARIA NAZARÉ LINS BARBOSA MARIA NEYÁRA DE OLIVEIRA ARAÚJO MARIA NIZEUDA BEZERRA

MARIA PAOLA DI SESSA DE LUCA OMETTO

MARIA PEREIRA NASCIMENTO

MARIA RAFAELA OLIVEIRA MARIA ROSICLEIDE N. ARAÚJO 
MARIA SALETE BATISTA FREITAG

MARIA SCARLET DO CAMPO

MARIA STAEL BITTENCOURT

MADUREIRA

MARIA TERESA CHENAUD SÁ OLIVEIRA

MARIA TERESA MICELI KERBAUY

MARIA TEREZA FLORES-PEREIRA

MARIA THAÍSE GOMES DE OLIVEIRA

MARIA VALERIA GASPAR DE QUEIROZ

FERREIRA

MARIA VALERIA SILVA

MARIA VANDERLEIA DE SOUZA

MARÍA VERÓNICA LAZO

MARIA VIRGINIA MACHADO DAZZANI

MARIA VITÓRIA DE SOUZA DANTAS

GRAMACHO

MARIA ZULEIDE LIMA REINALDO

MARIA-FATIMA SANTOS

MARIANA BALEEIRO MARTINS

CARRERA

MARIANA BARBOSA LIMA

MARIANA BEZERRA LYRA

MARIANA BRUNELLI

MARIANA BUENO DE ANDRADE

MARIANA CARLOS DE ANDRADE LYRA

MARIANA CARNEIRO DE SOUZA

MARIANA COSTA CARVALHO

MARIANA DE FREITAS COELHO

MARIANA DE LIMA CAEIRO

MARIANA FERNANDES DA CUNHA

LOUREIRO AMORIM

MARIANA FERRETI LIPPI

MARIANA GEISEL MARTINS

MARIANA LIMA BANDEIRA

MARIANA MARTINS

MARIANA MAZZINI MARCONDES

MARIANA MORAIS POMPERMAYER

MARIANA MUSETTI MUNCK

MARIANA RIBEIRO DE CASTRO

MARIANGELA KRETZER MARTINS

MARIÂNGELA WANDERLEY

MARIANNE CARLE-MARSAN

MARICLER WOLLINGER KOVALCZUK

MARIE AGNES CHAUVEL

MARIE ANNE MACADAR

MARIE-ANNE STIVAL PEREIRA E LEAL

LOZANO

MARILENA JAMUR

MARILENE MAIA

MARÍLIA FERNANDES MACIEL GOMES

MARÍLIA PINHEIRO FALCIONI PEREIRA

MARÍLIA VERÍSSIMO VERONESE

MARILSA DE SÁ RODRIGUES TADEUCCI

MARILUCE PAES DE SOUZA
MARINA APARECIDA LIMA

MARINA BATISTA DA SILVA

MARINA DE ALMEIDA CRUZ

MARINA DE CAMPOS CURSINO

MARINA GRUSKA BENEVIDES

MARINA SILVEIRA MÁXIMO

MARINA TONELI SIQUEIRA

MARINALDO PEREIRA JÚNIOR

MARINDIA BRACHAK DOS SANTOS

MARINEIA ALMEIDA DOS SANTOS

MARINEIDE NUNES DE SOUZA

MARIO COUTO SOARES PINTO

MARIO DA SILVA OLIVEIRA

MÁRIO LÚCIO DE ÁVILA

MARIO RAPOSO

MARIO REZENDE HUEZO

MARIO ROITTER

MARIO STEFFEN

MÁRIO TEIXEIRA REIS NETO

MARISA CAMARGO

MARISA DOS REIS A. BOTELHO

MARISA MAROTTA DE REZENDE

MARISE SCHADECK

MARÍSIA MONTE SILVA AGUIAR

MARISTELA JORGE MELO

MARIZA GANDOLFI

MARK JONNES MADEIRA

MARKLIZE DOS SANTOS SIQUEIRA

MARKUS ERWIN BROSE

MARLENE KOHLER DAL RI

MARLENE MARCHIORI

MARLENNY DÍAZ CANO

MARLETE INÊS STURM

MARLI DE FÁTIMA FERRAZ DA SILVA

TACCONI

MARLI HELENA DUARTE

MARLISE COSTA BEBER

MARLISE SOZIO VITCEL

MARLON DALMORO

MARLOS ANDRÉ PEREIRA DE JESUS

MARLOS VINÍCIUS OLIVEIRA RAMOS

MARLY CANASSA

MARNETTE S.FRAGA

MARTA BENJAMIM DA SILVA

MARTA FABIANO SAMBIASE

MARTA FENNER

MARTA LILIANA CERRANO

MARTA LUCIA AZEVEDO FERREIRA

MARTA SAMBIASE LOMBARDI

MARTINHO LUIS KELM

MARX RODRIGUES DOS REIS

MARYSTELA ASSIS BARATTER

MATEUS CARVALHO DE ALMEIDA

MATEUS CERQUEIRA ANÍCIO MORAIS 
MATHEUS BENEDITO MOREIRA TEIXEIRA

MATHEUS HENRIQUE SOUZA SANTOS

MATHEUS RIBEIRO DE ALMEIDA

MATHEUS SILVEIRA AZEVEDO

MATIAS POLI SPERB

MAURA DINORAH DA SILVA MOTTA

MAUREN DO COUTO SOARES

MAURÍCIO BARTH

MAURICIO FERNANDES PEREIRA

MAURÍCIO FOLLI CONCEIÇÃO

MAURÍCIO GREGIANIN TESTA

MAURÍCIO HOESCHL MENDONÇA

MAURÍCIO JOSÉ SERPA BARROS DE

MOURA

MAURÍCIO REINERT NASCIMENTO

MAURICIO VASCONCELLOS LEÃO

LYRIO

MAURINHO LUIZ DOS SANTOS

MAURO CÉLIO ARAÚJO DOS REIS

MAURO EDUARDO JURNO

MAURO JOSÉ DE OLIVEIRA

MAX GONDIM DE ALBUQUERQUE

MAXIMILIANO FRANCISCO DE

OLIVEIRA

MAYANY SOARES SALGADO

MAYARA ANDRESA PIRES DA SILVA

MAYRA BITENCOURT BATISTA

MAYRA TAIZA SULZBACH ARTIGO

MAZZON ROQUE MAIA DE SOUSA

MÉGUI FERNANDA DEL RÉ

MELBY KARINA ZUNIGA HUERTAS

MELISSA GIACOMETTI DE GODOY

MELISSA PONGELUPPI

MICHAEL CERQUEIRA DE OLIVEIRA

MICHELAINE MACHADO MACIEL DA

SILVA

MICHELE CRISTINA DUARTE DA SILVA

MICHELLE DE SÁ PEDRA

MICHELLE MUNIZ BRONSTEIN

MICHELLE PINTO DE LIMA

MIGUEL ÂNGELO DA SILVA COLAÇO

MIGUEL ANGELO GOMES

MIGUEL RIVERA PERES JÚNIOR

MILBERT FERNANDES MORAIS

BOURGUIGNON

MILENA PAVAN SERAFIM

MILENA SANTOS

MILTON DE ABREU CAMPANÁRIO

MILTON JÚLIO DE CARVALHO FILHO

MILTON YAMAMOTO

MIRELA CASTRO SANTOS CAMARGOS

MIRENA GENTILEZZA DE FIGUEIREDO BRITO
MIREYA EUGENIA VALENCIA PERAFÁN

MÍRIAM DE CASTRO POSSAS

MIRIAM FELICIANO DE BARROS

MIRIAM MEDINA VELASCO

MIRIAM MOURA VITAL

MIRIAN BECCHERI CORTEZ

MIRIAN CERQUEIRA SENA

MIRIAN DE SOUZA VIANA

MIRIAN JAMCOME MACHADO

MIRIAN MIRANDA COHEN

MIRIAN ROSA DO VALLE

MOACYR COSTA JÚNIOR

MODESTO LEITE ROLIM NETO

MOHAMED AMAL

MOISÉS HABIB BECHELANE MAIA

MÔNGOLLA KEYLA FREITAS DE ABREU

MÔNICA APARECIDA DA ROCHA SILVA

MÔNICA BARBOSA

MONICA BOSE

MÔNICA DE FÁTIMA BIANCO

MÔNICA MAC-ALLISTER

MÔNICA MARIA MENDES LUNA

MÔNICA MATOS RIBEIRO

MÔNICA MONTEIRO LIAUSU

CAVALCANTI

MÔNICA MOTA TASSIGNY

MÔNICA RAMOS CARNEIRO

MÔNICA TELES MARTINS

MONICA ZAIDAN GOMES ROSSI

MONIKE EMANUELLE SILVA FEITOSA

MONIQUE MALLON

MONIQUE TERRA SILVA

MORGANA G. MARTINS KRIEGER

MOSSICLÉIA MENDES DA SILVA

MÚCIO TOSTA GONÇALVES

MURILO CAMPOS ROCHA LIMA

MYCHEL DE OLIVEIRA FIGUEREDO DOS

SANTOS

NÁDIA CAMPOS PEREIRA

NÁDIA NARA ROLIM LIMA

NÁDIA VIANNA

NADJA GJHEUCA DA SILVA DUTRA

MONTENEGRO

NADJA MEDEIROS JUSTINO DA SILVA

NAGILANE PASSOS OLIVEIRA

NAIARA MARIA SANTANA NEVES

NAILA FERNANDA SBSCZK PEREIRA

MENEGUETTI

NAIRA MICHELLE ALVES PEREIRA

NAJLA CLÉCIA MOTA CAVALCANTE

SCACCABAROZZI

NÁLBIA DE ARAÚJO SANTOS

NANCY J. ADLER

NANCY PIEDAD DIAZ ORTIZ 
NAPOLEÃO DOS SANTOS QUEIROZ NARCISO FEITOSA DE OLIVEIRA NARDA MARGARETH GOMES DE SOUZA

NATÁCIA LAMOGLIA DE SOUZA

NATALIA CARDOSO MARRA

NATALIA DELGADO

NATÁLIA GUERRA RABELO

NATÁLIA LATINO ANTEZANA

NATÁLIA LÚCIA DA SILVA PINTO

NATÁLIA MENEZES MARTINS FONSECA

NATÁLIA MESQUITA

NATALIA NAVARRO DOS SANTOS

NATÁLIA PASCOALI BOEIRA

NATÁLIA REAL PEREIRA

NATÁLIA SOARES RIBEIRO

NATÁLIA XAVIER BUENO

NATANAEL CONCEIÇÃO ROCHA

NATANEL NOGUEIRA DIAS

NATANI CAROLINA SILVEIRA

NATHALIA GOMES

NATHÁLIA VASCONCELOS TAVARES

NAYANE FORMIGA DOS SANTOS

NAYARA KATRYNE PINHEIRO SERAFIM

NAYARA LUIZA FREIRE

NEIDE ALMEIDA BERES

NEIDE LARA DE SOUZA BROERING

NEIDE RIBAS DA LUZ SCARPARO

CUNHA

NEILA CONCEIÇÃO VIANA DA CUNHA

NEILA KAROLINA MENDES LIRA

NEIVA ANDRADE CAIRES

NELI APARECIDA DE MELLO-THÉRY

NELITA GONÇALVES FARIA DE BESSA

NELLY FOSTER FERREIRA

NELSON CORREA DE OLIVEIRA JUNIOR

NELSON GOUVEIA

NEMRE ADAS SALIBA

NEREIDA SALETTE PAULO DA

SILVEIRA

NERIZE LAURENTINO RAMOS

NEUSA MARIA DE SOUSA

NEUZAÍ MARREIROS BARBOSA

NEWTON BARRETTO LINS

NEY PAULO MOREIRA

NICÁCIA LINA DO CARMO

NICEMARA CARDOSO SILVA

NICOLAS CORTEZE

NILCÉLIA SOUZA DOS SANTOS

NILDA MARIA DOMINGOS MENDES,

NILDES RAIMUNDA PITOMBO LEITE

NILMA MORCERF DE PAULA

NILO MOREIRA DE SOUZA

NILSON DOS SANTOS BEZERRA
NILTON VASCONCELOS

NILZA DUARTE ALEIXO DE OLIVEIRA

NINA J. BEST

NINA ROSA DA SILVEIRA CUNHA

NOEL SCOTT

NOELIA DA SILVA MACHADO

NOEMI ALICE OLIVEIRA BONINA

COSTA

NORBERTO HOPPEN

NORIO KAWAKAMI

NORTON GONZÁLEZ

OCTAVIO AMORIM NETO

OCTAVIO PENNA PIERANTI

ODAIR DE SOUZA CUNHA JUNIOR

ODERLENE VIEIRA DE OLIVEIRA

OMER CHOUINARD

ORLANDO CALIMAN

ORLANDO ROQUE DA SILVA

ORLANDO VIEIRA DE CASTRO JÚNIOR

ORLEANS SILVA MARTINS

OSCAR ALMEIDA BISPO

OSCAR CHASSAGNES IZQUIERDO

OSCAR SARCINELLI

OSÓRIO CARVALHO

OSORIO CARVALHO DIAS

OSVALDO LUIS GONÇALVES QUELHAS

OSWALDO GONÇALVES JUNIOR

ÓSWALDO SANCHEZ JUNIOR

PABLÍCIO GOMES DOS SANTOS

PABLO ALEXANDRE

PABLO MONJE-REYES

PALOMA ALBINO BORBA CAVALCANTI

PALOMA MARIA SANTOS

PALOMA PALMIERI ALVES

PAMELA TORRES DE OLIVEIRA

PAOLA SICLARI BRAVO

PATRICIA ARAÚJO HENDERSON

PATRICIA ARAUJO RIOS

PATRICIA BERNARDES

PATRÍCIA BRITO DE ÁVILA

PATRÍCIA CARVALHO CAMPOS

PATRÍCIA CRISTINA DE ARAGÃO

ARAÚJO

PATRÍCIA DE SOUZA BRAZ

PATRICIA GLAUCIA MORENO

PATRÍCIA HONÓRIO DE FREITAS

PATRÍCIA KOTHE

PATRÍCIA LACZYNSKI

PATRÍCIA MARIA DA SILVA

PATRÍCIA MATIAS SOARES

PATRÍCIA MONTEIRO GORNI

PATRÍCIA MOREIRA DA ROCHA

AMARAL DE SOUZA

PATRICIA MORILHA MURITIBA 
PATRICIA RIBEIRO

PATRÍCIA ROSVADOSKI-DA-SILVA

PATRÍCIA SELIS GOMES

PATRICIA TOMETICH

PATRÍCIA VARA BRUSCH

PATRÍCIA VIVEIROS DE CASTRO

KRAKAUER

PATRÍCIA WEBBER SOUZA DE

OLIVEIRA

PATRICK MICHEL FINAZZI SANTOS

PATRUS ANANIAS

PAULA BONAZZI CREMONEZZI

PAULA ESTEBAN DO VALLE JARDIM

PAULA FERNANDES FURBINO BRETAS

PAULA FRONZA

PAULA KARINI DIAS FERREIRA

AMORIM

PAULA MACIEL PEDROTI

PAULA MARA COSTA DE ARAUJO

PAULA NAVARRO CANELHAS

PAULA PESSOA DE CASTRO

PAULA RACCANELLO STORTO

PAULA SOUZA AMORIM

PAULO ALEXANDRE OLIVEIRA DE

FARIA

PAULO AUGUSTO P. DE BRITTO

PAULO BELGO MORAES

PAULO CASSANEGO JR

PAULO CESAR DE SOUSA BATISTA

PAULO COSTA

PAULO DE TARSO MUZY

PAULO DOURIAN PEREIRA DE

CARVALHO

PAULO EDUARDO DE LACERDA

PAULO EDUARDO SILVA LINS

CAJAZEIRA

PAULO HENRIQUE GONDIM DE FREITAS

PAULO HENRIQUE LEME

PAULO HENRIQUE NOBRE PARENTE

PAULO HENRIQUE RAMOS MEDEIROS

PAULO JOSÉ DE SOUZA

PAULO JOSÉ SILVA

PAULO LESTER

PAULO LOURENÇO DOMINGUES

JUNIOR

PAULO MARCOS DOS REIS CIRO

PAULO RENATO APARECIDO SILOTO

PAULO RICARDO ZILIO ABDALA

PAULO ROBERTO ANDERSON

MONTEIRO

PAULO ROBERTO DA COSTA VIEIRA

PAULO ROBERTO PREZOTTI FILHO

PAULO ROBERTO RAMOS

PAULO SANTANA REGO GOMES
PAULO VINICIUS TEIXEIRA DE JESUS

PAULO VÍTOR GUERRA

PEDRINA VIANA DA SILVA

PEDRO ANTONIO DE MELO

PEDRO COSTA

PEDRO EMANUEL TEIXEIRA ROCHA

PEDRO H. M. ALBUQUERQUE

PEDRO HENRIQUE ALMEIDA DE SOUZA

ROCHA

PEDRO HENRIQUE BRAGANÇA DOS

SANTOS

PEDRO HENRIQUE DUARTE OLIVEIRA

PEDRO JOSÉ STEINER NETO

PEDRO LUÍS BÜTTENBENDER

PEDRO LUIZ CÔRTES

PEDRO NOVAIS

PEDRO ROSAS MAGRINI

PEDRO WILSON RAMOS DA CONCEIÇÃO

PERCY BAPTISTA SOARES NETO

PETER BENT HANSEN

PHILIPP DANIEL HAUSER

PIETRO CARMIGNANI

PÍTIAS TEODORO LACERDA

POLA RIBEIRO

POLLYKENNYA KERYNYNNE FERREIRA ALVES

POTY COLAÇO FONSECA

PRICILLA DE SOUZA ANDRADE

PRISCILA BORIN DE OLIVEIRA CLARO

PRISCILA DE SOUZA

PRISCILA LACZYNSKI DE SOUZA

MIGUEL

PRISCILA NARDI MOREIRA

PRISCILA PERAZZO

PRISCILA PEREIRA SANTOS

PRISCILA THAYANE CARVALHO SILVA

PRISCILLA SAYONARA DE SOUSA

BRANDÃO

RAFAEL AUGUSTO FERREIRA ZANATTA

RAFAEL AUGUSTO VECCHIO

RAFAEL CALDAS BARROS PEIXOTO

RAFAEL CAPUANO DA CRUZ

RAFAEL COSTA LIMA

RAFAEL D'ALMEIDA MARTINS

RAFAEL DE ALMEIDA ALVES

RAFAEL DE BRITO DIAS

RAFAEL DEOLINDO PEREIRA

RAFAEL DOS SANTOS DA SILVA

RAFAEL FABIANO RAVAZOLO

RAFAEL FACHINI MORATELLI

RAFAEL FERNANDES DE MESQUITA

RAFAEL ILLENSEER

RAFAEL JACQUES RODRIGUES

RAFAEL LARA MAZONI ANDRADE 
RAFAEL LIBERAL FERREIRA SANTANA

RAFAEL LUCIAN

RAFAEL MADUREIRA DOS ANJOS

RAFAEL MAGNUS BARBOSA MOSER

RAFAEL MORAIS PEREIRA

RAFAEL MORCH

RAFAEL MOSER

RAFAEL NISHINO ONO

RAFAEL PEREIRA OCAMPO MORÉ

RAFAEL PEREIRA OLIVEIRA

RAFAEL VECCHIO

RAFAELA ALBUQUERQUE VALENÇA DE ARAÚJO

RAFAELA GARCIA ARAÚJO

RAILENE DE SOUZA VELOSO

RAIMUNDA MACIEL SACRAMENTO

MALAFAIA

RAIMUNDO NONATO LIMA FILHO

RAIMUNDO NONATO SOUSA DA SILVA

RAIMUNDO NONATO SOUZA BOUTH

RAIMUNDO PÉRICLES MATOS BARROS

RAIMUNDO SANTOS LEAL

RAIMUNDO WELLINGTON ARAÚJO

PESSOA

RAINER RANDOLPH

RAISSA KAREN LEITINHO SALES

RAIZA MADJE TAVARES DA SILVA

RAMON SILVA LEITE

RANDAL MARTINS POMPEU

RANIERE DOS SANTOS LIMA

RAONI AZEREDO

RAPHAEL DE JESUS CAMPOS DE

ANDRADE

RAPHAEL JONATHAS DA COSTA LIMA

RAPHAELA REIS CONCEICAO CASTRO

SILVA

RAQUEL ALVES FURTADO

RAQUEL BARRETO

RAQUEL DE CARVALHO NASCIMENTO

RAQUEL FARIAS GREGÓRIO BEZERRA

RAQUEL FERREIRA LEITE FIGUEIREDO

RAQUEL LIE KISHI

RAQUEL LOPES SINIGAGLIA CARIBÉ

GRANDO

RAQUEL MARIA DE OLIVEIRA

MEDEIROS DE MELO

RAQUEL SOBRAL NONATO

RAQUEL WIGGERS

RAUL PUIGBONET

RAYANE CRISTINA DE ANDRADE GOMES

RAYANNA NAYHARA OLIVEIRA DO

NASCIMENTO

REBECA RIBAS BULHOSA
REBECCA ISABELLE HERCULANO

SILVA

REGIANE BALESTRA VIEIRA

REGINA CELESTE DE ALMEIDA SOUZA

REGINA FERREIRA DE ARAUJO DINIZ

REGINA FLÁVIA ARAÚJO DA CUNHA

REGINA MARIA MEIRELLES

BERGEMANN

REGINA MITIKO NAKAYAMA

REGINALDO DE JESUS CARVALHO

LIMA

REGINALDO SANTOS

RÉGIS RATHMANN

REINALDO DIAS

REJANE DE OLIVEIRA NAZÁRIO

REJANE MARIA ALIEVI

REJANE ROECKER

RENAN AURÉLIO FERREIRA ZANATTA

RENAN FELINTO DE FARIAS AIRES

RENAN FERREIRA ZANATTA

RENAN VILELLA FERREIRA

RENATA ALMEIDA ANDRADE

RENATA AMARAL

RENATA BARCELOS MOREIRA SANTOS

RENATA CAMARGO DUCA

RENATA CAROLINA CASTELLUBER

BELLUMAT

RENATA CÉLI MOREIRA DA SILVA

RENATA COSTA LEAHY

RENATA DE ANDRADE ALMEIDA DA

SILVA

RENATA DE OLIVEIRA SILVA

RENATA GOMES DE JESUS

RENATA GOUVÊA FARES

RENATA GUIMARÃES HORTA

RENATA MALPICA CALDEIRA

RENATA PORTO BUGNI

RENATA QUINTAS SPINELLI

RENATA VELOSO POLICARPO

RENATO CADER DA SILVA

RENATO FERREIRA DE OLIVEIRA

RENATO JOSÉ ALVES DE FIGUEIREDO

RENATO LINHARES DE ASSIS

RENATO LUIS PINTO MIRANDA

RENATO RODRIGUES DIAS

RENATO ZANCAN MARCHETTI

RENE BERGEL

RENE EUGENIO SEIFERT

RENNAN LANNA MARTINS MAFRA

REZIERE DEGOBI DA SILVA

RICARDO ALEXANDRE DOS SANTOS

ARAÚJO

RICARDO ALMEIDA MARQUES

MENDONÇA 
RICARDO ANTONIO CORRÊA

RICARDO BEZERRA DE MENEZES

RICARDO BRAGA VERONEZE

RICARDO CURI GOULART

RICARDO DASILVA

RICARDO ERNESTO VASQUEZ

BELTRÃO

RICARDO GARCIA

RICARDO LUIZ PEREIRA BUENO

RICARDO PEREIRA REIS

RICARDO PESCAROLO IOCHPE

RICARDO SILVEIRA MARTINS

RICARDO ZAGALLO CAMARGO

RIOVALDO ALVES DE MESQUITA

RITA DE CÁSSIA CHIÓ SERRA

RITA DE CÁSSIA OLIVEIRA PEDREIRA

RITA GABRIELLA LOBO ARRUDA

RIVELLE RIVÉTRIA SANTANA DOS

SANTOS

ROBERT H. WILSON

ROBERTA APARECIDA NEVES GRANITO

ROBERTA ATHERTON MAGALHÃES

DIAS

ROBERTA CLEMENTE

ROBERTA DE CÁSSIA MACEDO

ROBERTA MARTINS XAVIER

ROBERTA RAQUEL

ROBERTA SANT'ANDRÉ

ROBERTA SILVA DE CARVALHO

SANTANA

ROBERTA SIMONETTI

ROBERTO BRAZILEIRO PAIXÃO

ROBERTO DO NASCIMENTO FERREIRA

ROBERTO GIRO MOORI

ROBERTO GUIMARÃES

ROBERTO GUIMARÃES PEREIRA

ROBERTO JOSÉ TRIPODI MARCHI

ROBERTO LIMA RUAS

ROBERTO S. BARTHOLO JR.

ROBERTO SALLES XAVIER

ROBERTO SCHOPRONI BICHUETI

ROBSON MALACARNE

ROBSON TEIXEIRA DO LAGO

ROCÍO ALONSO LORENZO

RODOLFO ARAUJO DE MORAES FILHO

RODOLFO MUANIS F. DE CASTRO

RODRIGO BOUSFIELD

RODRIGO BANDEIRA-DE-MELLO

RODRIGO BARONI DE CARVALHO

RODRIGO CÉSAR SEVERINO NEIVA

RODRIGO CHALOUB DIEGUEZ

RODRIGO CIT RAMOS LOPES

RODRIGO CLAUDINO CORTEZ
RODRIGO DE LOSSO DA SILVEIRA

BUENO

RODRIGO GAYGER AMARO

RODRIGO GUEDES VIEIRA

RODRIGO LADEIRA

RODRIGO MARTINS BAPTISTA

RODRIGO MAURÍCIO FREIRE SOARES

RODRIGO OTÁVIO LIMA DE JESUS

RODRIGO PEREYRA DE SOUSA COELHO

RODRIGO RODRIGUES DOS SANTOS

RODRIGO SANTOS DE MELO

RODRIGO SERPA PINTO

RODRIGO SERRA

RODRIGO SOARES

ROGÉRIO PALHARES ZSCHABER DE

ARAÚJO

ROGÉRIO CERÁVOLO CALI

ROGÉRIO DE OLIVEIRA E SÁ

ROGÉRIO KUNZLER

ROGÉRIO R. M. FERREIRA

ROGÉRIO UBIRATÃ HAMEL BUENO

ROMMEL CAVALCANTI SILVA ARAUJO

RÔMULO JOSÉ DE OLIVEIRA ZURRA

RONALDO AUGUSTO CAMPOS PESSOA

RONAN TORRES QUINTÃO

RONY KLAY VIANA DE FREITAS

ROOSEVELT BEZERRA DA SILVA FILHO

ROSA MONTEIRO

ROSALBA MORAIS

ROSALI BRAGA FERNANDES

ROSÁLIA RODRIGUES ALVES

ROSAMARIA COX MOURA-LEITE

ROSANA BEATRIZ GONÇALVES

ROSANA C. M. GRILLO GONÇALVES

ROSANA C. SANJULIANO TOZATO

ROSANA CÓRDOVA GUIMARÃES

ROSANA DA ROSA PORTELLA

TONDOLO

ROSANA KISIL

ROSANA MARA MAZARO

ROSANA MARIA COSTA FERNANDES

ROSANA MARIA GAIO

ROSANA MARQUES

ROSANA MARQUES LIM

ROSANA OTSUBO

ROSANE CRISTINA JACQUES

ROSANGELA DURAES DOS SANTOS

ROSÂNGELA QUEIROZ SOUZA

VALDEVINO

ROSÂNGELA ROSA DE OLIVEIRA

ROSE JEOKELLYANE DO VALLE

MOREIRA

ROSE MARY MADURO CAMBOIM DE

AZEVEDO 
ROSEANE DO SOCORRO BRABO DA SILVA

ROSEANE F. AQUINO

ROSEANNE AZEVEDO DE

ALBUQUERQUE

ROSELEI HAAG

ROSELI BUENO DE ANDRADE

ROSELY ALVIM SANCHES

ROSELY RODRIGUES

ROSELY SAMPAIO

ROSEMARY PEREIRA COSTA E

BARBOSA

ROSENI APARECIDA DE MOURA

ROSIANE SILVA PEREIRA

ROSILAINE APARECIDA PINTO

ROSILENE MARCON

ROSIMERE MIRANDA FORTINI

ROSIMERI DE FÁTIMA CARVALHO DA

SILVA

ROSINEIDE VIEIRA

ROSSANA FILETTI SORANZ

ROZALI ARAUJO DOS SANTOS

RUBEM CASTRO NEVES

RUBENS LIMA MORAES

RUBIA FONSECA ROBERTO

RÚBIA OLIVEIRA CORRÊA

RÚBIA SEDEMAKA SILVA

RUDICLAI DA COSTA SILVA

RUI ALEXANDRE CHRISTOFOLETTI

RUI AMÉRICO M. HORTA

RUTE ABREU

RUTHBERG DOS SANTOS

RUTHY NADIA LANIADO

RUY DE QUADROS CARVALHO

SABRINA DE MELO CABRAL

SABRINA DELLAPIANE

SABRINA GOMES DOS SANTOS

SABRINA LETÍCIA COUTO DA SILVA

SABRINA MARINHO OST

SABRINA MELO CABRAIL

SABRINA SILVA DE CARVALHO

SABRINA ZANOTTI GALLON REIS

SALOMÃO ALENCAR DE FARIAS

SÂMARA AYESKA SILVA TEODORO

SÂMARA BORGES MACEDO

SAMIRA BUENO NUNES

SAMUEL FAÇANHA CÂMARA

SAMUEL FELIPPE

SAMUEL PINTO COLEN

SAMYLE PINTO DOS SANTOS

SANDER ROBERTO MAURANO FILHO

SANDRA CRISTINA FURTADO

SANDRA HACON

SANDRA HELENA RIBEIRO CRUZ
SANDRA HELENA SOUZA MACHADO

NASCIMENTO

SANDRA INÊS BARAGLIO GRANJA

SANDRA MARA DE ANDRADE

SANDRA MARA MATUISK MATTOS

SANDRA MARIA CHAVES DOS SANTOS

SANDRA REGINA DA ROCHA-PINTO

SANDRA REGINA GOMES

SANDRA REGINA NISHIMURA

SANDRA ROLIM ENSSLIN

SANDRO AMARAL NOGUEIRA

SANDRO BENEDITO SGUAREZI

SANDRO PASINI

SANTIAGO FALLUH VARELLA

SARA CONCEIÇÃO DE PAULA

SARA DA SILVA FREITAS

SARAH SANTOS ALVES

SARAH TARSILA VASCONCELOS

SANTOS

SARITA DE MOURA

SAULO DE SOUZA RODRIGUES

SAULO ROCHA

SÁVIO BERTOCHI CAÇADOR

SCARLET CARMO

SEPULVEDA MÔNICA FONSECA

SERAFIM FIRMO DE SOUZA FERRAZ

SERGIO AUGUSTO PEREIRA BASTOS

SERGIO AZEVEDO FONSECA

SERGIO B. DE ARRUDA SAMPAIO

SÉRGIO CARDOSO DE MORAES

SÉRGIO CHAMADOIRA MENDONÇA

SILVA

SERGIO DANTAS

SERGIO DE ARRUDA SAMPAIO

SÉRGIO DIAS RIBEIRO

SERGIO FIRPO

SERGIO LUIS DIAS DOLIVEIRA

SÉRGIO MARTINS

SERGIO MORO JUNIOR

SÉRGIO NUNES MURITIBA

SÉRGIO PAULO RAMIRES JÚNIOR

SERGIO PROENÇA LEITÃO

SERGIO ROZENBAUM

SÉRGIO SAMPAIO

SERGIO SOBREIRA ARAUJO

SERGIO VINICIUS LOUZADA

SEVERIANO JOSEH SANTOS JR.

SEVERINO JOAQUIM NUNES PEREIRA

SHANA SABBADO FLORES

SHAYNA SARA HARRIS

SHEILA CRISTINA TOLENTINO

BARBOSA

SHIRLE ROSÂNGELA MEIRA DE

MIRANDA 
SIDA SILVA

SILMA ROSA DA SILVA MOREIRA

SILVANA APARECIDA DE AGUIAR

SILVANA KARINA DE MELO

TRAVASSOS

SILVANA MARIA RIBEIRO

SILVANA MARTA TUMELERO

SILVANA NUNES DE QUEIROZ

SILVANA RODRIGUES DE ANDRADE

SILVANIA NERIS NOSSA

SILVIA ANTONIA DE MORAIS

SILVIA BATISTA DE SOUZA

SILVIA CONCEIÇÃO BOMFIM

BITTENCOURT

SILVIA CRAVEIRO

SILVIA CRISTINA CAICEDO MUÑOZ

SÍLVIA DA SILVA CRAVEIRO

SILVIA GHERARDI

SILVIA HARUMI TOYOSHIMA

SILVIA HELENA BAQUIT CAMPOS

SILVIA MARIA DIAS PEDRO REBOUÇAS

SILVIA R. C. SALGADO

SILVIA REGINA MEIRA

SILVIA REGINA STARLING ASSAD DE

ÁVILA

SILVIA REGINA STUCHI CRUZ

SÍLVIA ROBERTA DE OLIVEIRA SILVA

SÍLVIA RODRIGUES BIO

SÍLVIO ALBERTO ROBEIRO MELO

SILVIO ANTONIO FERRAZ CÁRIO

SILVIO CEZAR AREND

SÍLVIO PARODI OLIVEIRA CAMILO

SILVIO ROBERTO STEFANO

SIMONE AMORIM

SIMONE AMORIM RAMOS

SIMONE ANDRADE TEIXEIRA

SIMONE CRISTINA DUFLOTH

SIMONE DE SOUZA

SIMONE FARIAS FONSECA

SIMONE M. DA S. LIMA

SIMONE MARTINS

SIMONE PEREIRA SILVA BASTOS

SIMONE SCUR

SIMONE SEHNEM

SIRIUS BULCÃO CARNEIRO

SIRLEI PITTERI

SLAYDSON ALVES LIMA

SOFIA REINACH

SOLANGE ALFINITO

SOLANGE EMILENE BERWIG

SOLANGE GARCIA DOS REIS

SOLANGE MARIA PIMENTA

SÔNIA ALBUQUERQUE ANDRADE

SONIA MARIA MARTINS PASSOS
SÔNIA REGINA DE MACÊDO

SONIA REGINA NASCIMENTO DE

OLIVEIRA

SÔNIA REGINA PAULINO

SONIA REGINA VARGAS MANSANO

SONIA VALLE WALTER BORGES DE

OLIVEIRA

SOUZA AMORIM

STEFANIA LAPOLLA CANTONI

STEFFEN BÖHM

STELLA CAMLOT REICHER

STELVIA MATOS

STEPHEN SCHWARTZMAN

STHAEL MARIANE ALMEIDA

CAVALCANTI

SUELEN BEVILAQUA

SUÉLEN GHEDINI MARTINELLI

SUELEN TANYS VILAS BOAS

SUELI DE FÁTIMA RAMOS SILVEIRA

SUELI GONÇALVES DA SILVA MAIA

SUELI MENDES VIEIRA

SUELY FÁTIMA SILVEIRA

SUELY RAMOS SILVEIRA

SULIANI ROVER

SUSANA CRISTINA HENRIQUES LEAL

SUSANA GAUCHE

SUSANA HAMILTON

SUSANE PETINELLI SOUZA

SUSANY PERARDT

SUZANA B. DE SOUZA SANTOS

SUZANA DA ROSA TOLFO

SUZANA DIAS RODRIGUES DE

OLIVEIRA

SUZANA QUINET DE ANDRADE BASTOS

SUZANA SALVADOR CABRAL

GIANOTTI

SUZANNE PIOTROWSKI

SUZANNY CARLA SANTOS ALMEIDA

SUZELY ADAS SALIBA MOIMAZ

SUZIMÉRI VILAS BÔAS PESCADOR

SYLVIA IASULAITIS

SYLVIA REJANE MAGALHÃES

DOMINGOS

TACIANA RITA SILVA

TACYANA KAROLINE ARAÚJO LOPES

TADEU GOMES TEIXEIRA

TAIANE RITTA COELHO

TAISA CECILIA DE LIMA CAIRES

TAISA DIAS

TAKEYOSHI IMASATO

TALITA CRISTINA ZECHNER LENZ

TALITA DE OLIVEIRA TRINDADE

TALITA PEREIRA DE CASTRO

TALITA SOARES MORAN 
TALYTA EDUARDO OLIVEIRA

TAMIRIS CRISTHINA RESENDE DA

SILVA

TÂNIA CRISTINA AZEVEDO

TÂNIA CRISTINA DOS SANTOS

TÂNIA FERREIRA DOS SANTOS BOMFIM

TÂNIA MARGARETE MEZZOMO

KEINERT

TÂNIA MARIA DE OLIVEIRA ALMEIDA

GOUVEIA

TANIA PEREIRA CHRISTOPOULOS

TANIA REGINA DE OLIVEIRA

MACHADO

TARCITA CABRAL GHIZONI DE SOUSA

TARLES LEMOS DO PRADO

TÁSSIA FERNANDES

TATIANA AQUINO ALMEIDA

TATIANA CRISTINA MAGGI

FERNANDES

TATIANA LEMOS SANDIM

TATIANA MARIA ARAUJO DA FONSECA

TATIANA TUCUNDUVA PHILIPPI

CORTESE

TATIANE AMANDA SIMM

TATIANE PELLIN CISLAGHI

TATIANE PEREIRA JORGE

TELMA COELHO DA SILVA

TENIZA DA SILVEIRA

TERESA OLINDA CAMINHA BEZERRA

TEREZA CRISTINA PAMPONET RIBEIRO

DANTAS

TEREZA CRISTINA PEIXOTO

TEREZINHA CABRAL ALBUQUERQUE

TEREZINHA VICENTI

THAIANE ORRICO

THAÍS CRISTINA DE BARROS NÓBREGA

THAIS ETTINGER OLIVEIRA

THAIS FERNANDES DIAS CAIRO

THAIS HELENA DE ANDRADE

THAÍS IKUHARA SANTOS

THAÍS PEREIRA MARTINS

THAIS RECOBA CAMPODONICO

THAIS SILVA MASCARENHAS

THAISA KELLY DA SILVA LIRA

THAÍSA RESTANI VERAS

THAISE COSTA GUZZATTI

THALES GUILHERME VAZ MARTINS

THALES TORRES QUINTÃO

THALITA ARBUSTI

THAYLA EMANUELLE DA SILVA

FERREIRA

THAYS MARCELLE PASCOAL

THAYSA DANYELLA LIRA DA SILVA

THEMISA ARAÚJO BARROSO PIMENTEL
THEOPHILO ALVES DE SOUZA FILHO

THIAGO ALVES

THIAGO CAVALCANTE NASCIMENTO

THIAGO CHAGAS SILVA SANTOS

THIAGO DE ALMEIDA SILVA

THIAGO DE OLIVEIRA E SILVA

THIAGO DUTRA HOLLANDA DE

REZENDE

THIAGO HARTENTHAL

THIAGO HECTOR KANASHIRO UEHARA

THIAGO JOSÉ ARRUDA

THIAGO LIMA BAHIA SANTOS

THIAGO MAXIMIANO DE OLIVEIRA DA

SILVA

THIAGO MOTA CARDOSO

THIAGO PINTO BARBOSA

THIAGO RODRIGO DE PAULA ASSIS

THIAGO SOUSA SILVEIRA

THYANA FARIAS GALVÃO DE BARROS

TIAGO ANTONIO QUIM FERREIRA

TIAGO DE ALENCAR VIANA

TIAGO JOSÉ GONZAGA BORGES

TIAGO PEREIRA DA SILVA

TIAGO RAIMUNDO FERREIRA CALADO

TIAGO VERANNEMAN DE WATERVLIET

TIARA OLIVEIRA CARDOSO

TOBIAS BEISE ULRICH

TOMAS DE AQUINO GUIMARAES

TOMÁZ DE AQUINO RESENDE

TOMAZ GERALDINO CARNEIRO DE

ARAÚJO

TOMMASO VITALE

TÚLIO MARCOS ALVES AZEREDO

UBIRATÃ TORTATO

UIARA GONÇALVES DE MENEZES

URSULA WETZEL

VAGNER ROSALEM

VALDICE BARBOSA DE QUEIROZ

VALDINHO PELLIN

VALDIR DE JESUS LAMEIRA

VALDIR FERNANDES

VALENTINI TRISTÃO

VALÉRIA DA VEIGA DIAS

VALÉRIA LEITE

VALERIA MARQUES ETTINGER

VALÉRIA MARQUES TAVARES DE

MENEZES ETTINGER

VALÉRIA REZENDE FREITAS BARROS

VALÉRIO ALÉCIO TURNES

VALÉRIO CARVALHO FILHO

VALMÍRIA CAROLINA PICCININI

VALQUÍRIA PADILHA

VALQUIRIA SOUTO DA SILVA

VANDA CATARINA DUARTE 
VANDERLEA LIMA SENA

VANDERLEI SOUZA CARVALHO

VANESSA ALVES MASCARENHAS

VANESSA CAMPAGNAC

VANESSA CARMELINA TOSO

VANESSA CHAVES DE FIGUEIREDO

VANESSA DO AMARAL DANTAS

VANESSA DOS SANTOS

VANESSA DOS SANTOS MEDEIROS

VANESSA FRAGA DE SOUZA

VANESSA GONZAGA FUMES

VANESSA H. WOTTRICH

VANESSA JOSÉ ROCHA

VANESSA LOUISE BATISTA

VANESSA MOREIRA SIGOLO

VANESSA PINTO

VANESSA S. FRAGA DE SOUZA

VANESSA SCHIMIDT

VANESSA SILVA PEREZ

VANESSA SIQUEIRA MANHÃES

VANESSA TAVARES DIAS

VÂNIA DE VASCONCELOS GICO

VANIA MARTINS PEREIRA

VANUZA BASTOS RODRIGUES

VANUZA DA SILVA FIGUEIREDO

VASCONCELOS REIS WAKIM

VENÍCIOS OLIVEIRA ALVES

VERA LÍGIA COSTA WESTI

VERA LÚCIA DA SILVA MIRANDA

VERA LUCIA DA SILVA VENTURA

VERA LÚCIA DE AGUIAR KELLY

VERA LÚCIA DE ALMEIDA CORRÊA

VERA LÚCIA SCHNEIDER BEMVENUTI

VERA MARIA MOURA ECHENIQUE DE

AZEVEDO

VERA RODRIGUES

VERA SPÍNOLA

VERÔNICA FEDER MAYER

VERÔNICA MACÁRIO DE OLIVEIRA

VERÔNICA PALUDO BRESSAN

VÉRONIQUE PERRET

VICENTE RICCIO

VICTOR AUGUSTO ARAÚJO SILVA

VICTOR CLÁUDIO PARADELA

FERREIRA

VICTOR CORRÊA SILVA

VICTOR DE OLIVEIRA

VICTOR MEYER JR.

VICTOR NATANAEL SCHWETTER

SILVEIRA

VICTOR NEIVA E OLIVEIRA

VICTOR RAMIRO FERNÁNDEZ

VILMAR ANTONIO GONÇALVES

TONDOLO
VINICIOS GONCHOROSKI DE OLIVEIRA

VINÍCIUS ALMEIDA

VINÍCIUS ANDRADE BREI

VINÍCIUS EDUARDO BELO RODRIGUES

VINICIUS FASULO TRANCOSO

VINÍCIUS FERREIRA BAPTISTA

VINICIUS M. FERREIRA

VINÍCIUS SILVA FLAUSINO

VINICIUS SILVEIRA MARQUES

VINÍCIUS SOUZA RIBEIRO

VIOLINA RINDOVA

VIRGÍNIA CAVALCANTE COELHO

VIRGÍNIA NOGUEIRA VIEIRA

VIRNA FERNANDES TÁVORA ROCHA

VITARQUE COELHO

VITOR BRAGA

VITÓRIA REGIA SAMPAIO

VIVIAN OLIVEIRA TAVARES

VIVIAN OSMARI UHLMANN

VIVIANE ANGÉLICA CAETANO

VIVIANE BRÁS DOS SANTOS

VIVIANE BRITO VIANA

VIVIANE DE MENEZES

VIVIANE QUÊNIA BRITO DE JESUS

VIVIANE RIEGEL

VIVIANE SILVA

VIVIANE SZABO

VIVIANNE BARROS NOGUEIRA

VIVINA MACHADO

VLADIMIR PONCZEK

WAGNER CORDENONSI TOMBI

WAGNER DE CARVALHO BARACAT

WAGNER DE JESUS MARTINS

WAGNER DO PRADO FERNANDES

WAGNER EUSTÁQUIO OLIVEIRA DA

COSTA

WAGNER JUNIOR LADEIRA

WAGNER RAGI CURI FILHO

WALDECY RODRIGUES

WALDEMAR ANTONIO DA ROCHA DE SOUZA

WALKYRIA CHAGAS DA SILVA SANTOS WALTER MARCOS KNAESEL BIRKNER

WÂNIA REZENDE SILVA

WASHINGTON LUIS DE SOUSA BONFIM

WELLES MATIAS DE ABREU

WENDELL LEPORE

WESLEI PIAU

WILLIAM BORGES

WILSON MENEZES

WILSON ROSSI

WILSON SANTOS NASCIMENTO

WILTON DE MEDEIROS DAHER 
WYLMOR CONSTANTINO TIVES DALFOVO

YAN VIEIRA DO CARMO

YANA TORRES DE MAGALHÃES

YARA PROBST BECKER

YEDA MARIA PEREIRA PAVÃO

YLANE DE ARAÚJO ALMEIDA
YNIS CRISTINE DE SANTANA MARTINS LINO FERREIRA

YUKIKO YAMAZAKI

YUMARA LUCIA VASCONCELOS

YVES EV RARD

YVON PESQUEUX

ZÉLIA MARIA DE OLIVEIRA FAJARDINI

ZILSA MARIA PINTO SANTIAGO 